\author{
Juliana Siani Simionato
}

\title{
A Marmota e seu Perfil Editorial: Contribuição para Edição e Estudo dos Textos Machadianos Publicados Nesse Periódico (1855-1861)
}

Dissertação apresentada ao Programa de Pósgraduação em Ciências da Comunicação, Área de Concentração Teoria e Pesquisa em Comunicação, Linha de Pesquisa Estética e História da Comunicação, da Escola de Comunicações e Artes da Universidade de São Paulo, como exigência parcial para obtenção do Título de Mestre em Comunicação, sob a orientação do Prof. Dr. Ivan Prado Teixeira.

São Paulo

2009 



\section{Comissão Julgadora}

Prof. Dr. Ivan Prado Teixeira

Assinatura

Prof. Dr. Plinio Martins Filho

Assinatura

Profa. Dra. Maria Eugênia Boaventura

Assinatura 



\section{RESUMO}

O objetivo do presente estudo foi reunir os textos de Machado de Assis publicados no jornal carioca Marmota, entre 1855 e 1861. Embora todo esse material já tenha sido editado, encontra-se disperso em diversas obras, muitas delas já esgotadas. O trabalho também buscou definir o quadro de produção dessas colaborações por meio de um ensaio sobre a Marmota - periódico atualmente pouco conhecido que esteve ativo entre 1849 e 1861 - e sua função cultural dentro do Segundo Reinado. Igualmente, tentou-se recompor a imagem do tipógrafo carioca Francisco de Paula Brito (1809-1861), proprietário e editor da Marmota.

\section{Palavras-Chave}

Editoração, literatura, Machado de Assis, Paula Brito, poética cultural, Marmota.

\section{Abstract}

The aim of the present study was to collect texts of Machado de Assis published in Marmota, a journal from Rio de Janeiro, between 1855 and 1861. Although the material had already been published, it is scattered in numerous works and many of them are out-of-print books. The study also attempted to define the production picture of these texts by means of an essay on Marmota - currently, a poorly known periodical that operated between 1849 and 1861 - and on its cultural function in the Second Reign. Similarly, a try to recriate the image of the typographer Francisco de Paula Brito (1809-1861) - owner and editor of Marmota - was made.

\section{KEY WORDS}

Publishing, literature, Machado de Assis, Paula Brito, cultural poetics, Marmota. 



\section{Agradecimentos}

Entre as muitas pessoas que colaboraram para a finalização do presente trabalho, agradeço com especial atenção ao Prof. Ivan Teixeira, cuja orientação foi sempre rigorosa e pronta, tanto na descoberta do assunto quanto nos conceitos e na redação do texto. Ao Prof. Plínio Martins, espécie de consciência moral da Editoração no CJE, agradeço não só sua argüição no exame preliminar do trabalho, mas também sua constante presença durante os anos de graduação e de estágio na Edusp. Sou igualmente grata à Profa. Maria Eugênia Boaventura, cujas perguntas no Exame de Qualificação, além de revelar leitura atenta e apurada, demonstraram senso de colaboração e interesse pelos rumos do trabalho. 



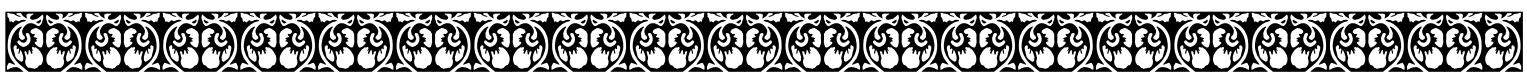 Sumário

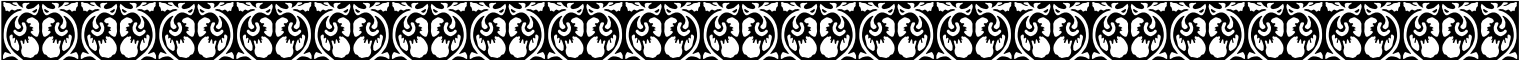

Parte 1 - Ensaios

Apresentação 3

Esboço 3

Ensaios 4

Edição 6

Capítulo 1 - A Marmota $\quad 9$

Esboços Românticos 10

Publicações Literárias da Primeira Metade do Século XIX 12

O Jornal 16

Diretriz Cultural do Jornal 37

A Marmota e D. Pedro II 53

Capítulo 2 - A Figura de Francisco de Paula Brito 63

Traço Inicial 63

Primeiro Relato Biográfico $\quad 64$

Segundo Registro Dedicado a Paula Brito 70

Biografia Definitiva $\quad 75$

Paula Brito nas Biografias Machadianas $\quad 92$

Paula Brito na História da Literatura no Brasil 95

Paula Brito na História da Imprensa Brasileira 99

$\begin{array}{ll}\text { Paula Brito na História da Cultura } & 101\end{array}$

Paula Brito na História da Cidade do Rio de Janeiro 105

Então, Quem Foi Paula Brito? 105

Capítulo 3 - Machado de Assis na Marmota 107

Temática Inicial 110 
Novas Propostas

Machado de Assis Prosador

PARTe 2 - Edição

Lista dos Textos Machadianos

Edição dos Textos Machadianos

Poesia

Ela

A Palmeira

A Saudade

Saudades

Júlia

Lembrança de Amor

154

Teu Canto

A Lua

Meu Anjo

Um Sorriso

Como Te Amo

Paródia

A Saudade

No Álbum do Sr. F. G. Braga

166

A uma Menina

168

O Gênio Adormecido 169

O Profeta

O Pão d'Açúcar

Soneto - A S. M. o Imperador, o Senhor D. Pedro II

Dormir no Campo

Minha Musa

Consumatum Est!

Um Anjo

Cognac!

Minha Mãe

Não?

Resignação

Amanhã 
O Sofá

Álvares de Azevedo

Vai-te 188

Esta Noite 189

Reflexo 190

A Morte no Calvário 190

Ao Carnaval de 1860 193

Prosa 195

Idéias Vagas - A Poesia 196

Idéias Vagas - A Comédia Moderna 197

Idéias Vagas - Os Contemporâneos - Mont’Alverne 199

A Literatura durante a Restauração 201

Três Tesouros Perdidos 208

Os Cegos 210

O Passado, o Presente e o Futuro da Literatura 223

Bagatela 228

Cousas que São Maçantes 238

Madalena 238

O Conservatório Dramático 255

Hoje Avental, Amanhã Luva 258

Odisséia dos Vinte Anos 269

Carniceira a Vapor 271

Anedota 273

O Termômetro Parlamentar 273

Queda Que as Mulheres Têm para os Tolos 274

Conclusões 283

Referências Bibliográficas 



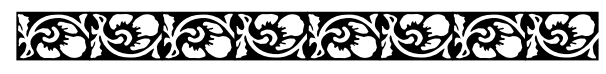

Parte 1

Ensaios

सम 



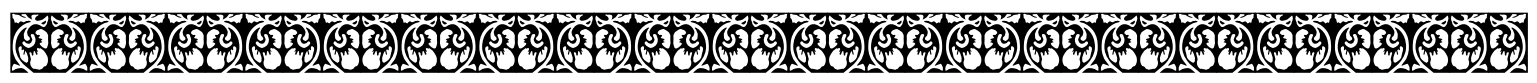 Apresentação

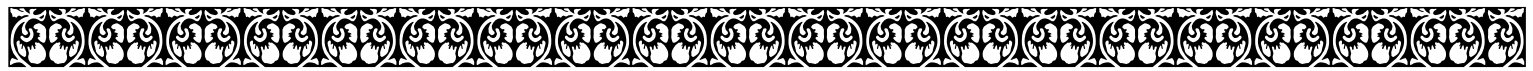

\section{3)}

A finalidade básica desse trabalho é reunir em volume pela primeira vez os textos que Machado de Assis editou na Marmota, jornal de variedades de Paula Brito, que circulou em diferentes fases no Rio de Janeiro, entre 1849 e 1864. A Marmota foi o primeiro jornal em que o jovem Machado de Assis colaborou de forma sistemática, continuamente desde 1855 até 1861. Durante muito tempo, acreditou-se que seu primeiro trabalho tornando público teria sido o poema "Ela", que saiu nessa folha em janeiro de $1855^{1}$. No entanto, depois, soube-se que a primazia cabia a um soneto publicado no Periódico dos Pobres, em outubro de $1854^{2}$.

Embora as colaborações machadianas para a Marmota já tenham saído em volume, encontram-se dispersas em diferentes obras, algumas de difícil acesso. Mesmo nos três volumes da Obra Completa de Machado de Assis, organizada por Afrânio Coutinho³, por exemplo, há poucos textos que foram originalmente editados nesse jornal.

O primeiro desses trabalhos a ganhar edição em livro foi a tradução Queda Que as Mulheres Têm para os Tolos, editado em $1861^{4}$ pela tipografia de Francisco de Paula Brito, proprietário e editor da Marmota. Posteriormente, o conto "Três Tesouros Perdidos" saiu no volume Páginas Recolhidas da coleção feita pela extinta editora W. M. Jackson em $1937^{5}$. A maior parte das poesias desse período encontra-se em Machado de Assis: Poesia e Prosa, organizado por J. Galante de Sousa ${ }^{6}$, de 1957, e em Dispersos de Machado de Assis, de Jean-Michel Massa ${ }^{7}$, de 1965. O ensaio de história e crítica literária "O Passado, o Presente e o Futuro da Literatura" foi incluído no terceiro volume da Obra Completa, organizada por Afrânio Coutinho8.

A iniciativa de agrupar em um único volume todos os texto acima mencionados e muitos outros - que formam uma unidade não apenas por razões cronológicas, mas também por pertencerem ao

1. Cf. J. Galante de Sousa, Bibliografia de Machado de Assis, p. 205.

2. Cf. Raimundo Magalhães Júnior, Vida e Obra de Machado de Assis, vol. 1: Aprendizado, pp. 17-21.

3. Afrânio Coutinho (org.), Machado de Assis: Obra Completa, 1959.

4. Rio de Janeiro, Tipografia de F. de Paula Brito, 1861.

5. Machado de Assis, Páginas Recolhidas, 1937.

6. J. Galante de Sousa (org.), Machado de Assis: Poesia e Prosa, 1957.

7. Jean-Michel Massa (org.), Dispersos de Machado de Assis, 1965.

8. Afrânio Coutinho (org.), op. cit., pp. 799-803. 
quadro cultural em que se insere o periódico em que tiveram sua primeira edição - tem como objetivo dar a conhecer, de forma prática e sistemática, o primeiro estágio da produção de Machado de Assis. Qual é a pré-história do autor de Memórias póstumas de Brás Cubas? Como se deu a transformação técnica e temática de sua obra? A proposta deste trabalho é reunir e divulgar essa fase pouco lembrada do autor, trazendo-a a público de forma unitária e coesa.

A primeira notícia sobre a totalidade dos textos de Machado de Assis publicados na Marmota vem de J. Galante de Sousa, em Bibliografia de Machado de Assis ${ }^{9}$. Por ser o mais completo, esse levantamento foi escolhido como base para a coletânea de textos machadianos a que este estudo se propõe.

No presente trabalho, parte-se da hipótese de que a Marmota pertencia ao que hoje se pode chamar de pequena imprensa. O jornal buscava dar ênfase a matérias ligadas a literatura e entretenimento, em oposição à grande imprensa do período, que se dedicava a textos mais noticiosos e aos debates políticos. Valorizar a literatura, para a Marmota - na forma de publicação de romances, poesias e de divulgação de novos autores -, talvez não fosse apenas um modo de incrementar a cultura nacional. Pode ter sido também uma estratégia de sobrevivência do jornal. Sabe-se que Paula Brito era pessoa de poucos recursos financeiros, e que naquela época, circular durante doze anos de forma ininterrupta, como fez a Marmota, era fato digno de nota e de conhecimento.

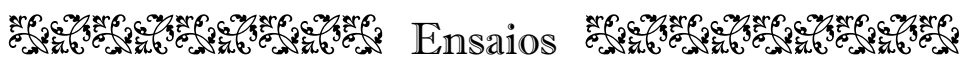

Se algum houver, supõe-se que o principal mérito do presente trabalho é a reunião, em um só volume, dos textos machadianos publicados na Marmota. Todavia, procurou-se, na medida do possível, fornecer subsídios básicos para uma apreciação cultural desse corpus, em três etapas distintas e complementares.

Primeiro, procurou-se produzir um ensaio sobre a dimensão histórica da Marmota, com destaque para seus aspectos editoriais, entendidos como intervenção efetiva do jornal na cultura de seu tempo. Sabe-se que há poucas referências à Marmota na literatura. Obras como História da Imprensa no Brasil, de Nelson Werneck Sodré, mencionam-na superficialmente, sem pretender informar sobre sua função cultural, limitando-se a reputá-la simplesmente como produtora de "romances e novelas anônimas, fabricadas aos montes para distrair o espírito das sinhazinhas e dos estudantes"10. Lúcia Miguel Pereira acaba por descaracterizar ainda mais o periódico, colocando-o em uma perspectiva bastante negativa, e até equivocada, com afirmações como essa: "A revista é quase toda composta de charadas rimadas, de acrósticos, dos versos cortesãos do Paula Brito, de sermões aos 'Irmãos Petalógicos', de sonetos mimosos. Um irrespirável ambiente de beletrismo, propício à floração da literatura de folhinha" "11. Há, ainda, obras que confundem a Marmota de Paula

9. J. Galante de Sousa, Bibliografia de Machado de Assis, 1955.

10. Nelson W. Sodré, História da Imprensa no Brasil, p. 222.

11. Lúcia Miguel Pereira, Machado de Assis (Estudo Crítico e Biográfico), pp. 62-63. 
Brito com os pasquins tidos como oposicionistas ao governo real e considerados "escandalosos" para a época, como faz $O$ Rio de Janeiro Imperial ${ }^{12}$.

Outra idéia que este trabalho procura desenvolver é a de que o jornal procurava sempre reafirmar e enaltecer a figura do imperador. Sabe-se por meio de registros como o de Lília Moritz Schwarcz que o natalício de Pedro II era data comemorativa oficial na corte ${ }^{13}$. Durante as consultas a Marmota, constatou-se que o jornal, em toda sua existência, sempre elaborava matérias elogiosas em homenagem ao imperador em seu aniversário. E, além disso, oferecia também artigos em honra à imperatriz e a toda estrutura organizada no entorno da família real. Não se trata de criticar por critério atuais essa folha de cultura, mas levantar dados que permitam entendê-la nos termos de sua existência histórica.

Depois, a atenção recaiu sobre a figura de Francisco de Paula Brito, momento em que se procurou analisar a construção de sua imagem durante a vida e após a morte. Procurou-se também organizar o maior número possível de informações sobre sua "Typographia", reconstituindo seu catálogo e caracterizando suas edições. A principal obra que oferece subsídios ao tema é, sem dúvida, Vida e Obra de Paula Brito, de Eunice Ribeiro Gondim. Além de conter uma biografia do tipógrafo, essa obra apresenta também uma bibliografia de periódicos por ele editados e de livros compostos em suas oficinas. Muitas obras, a partir da segunda metade do século XX, apropriamse das palavras de Gondim para produzir seus discursos acerca de Paula Brito. A própria autora declara, logo no início do livro, seu propósito de glorificação do biografado: "estamos situados em um ângulo de admiração, que nos levará a fazer um retrato simples e fiel, embelezado pelo que é bom e digno na transparente personalidade de Paula Brito" ${ }^{14}$, o que implica a idéia de uma biografia desenvolvida como elogio, não como exercício crítico e interpretativo.

Contemporâneo do tipógrafo, Manuel Duarte Moreira de Azevedo também contribuiu para a criação da imagem de Paula Brito que a história guarda. É ele o autor da "Biografia" constante nas páginas pré-textuais de Poesias de Francisco de Paula Brito. Afirma sobre Paula Brito: "O modesto impressor chegou a ser pelo seu trabalho, perseverança e estudo, o mais importante editor do país; aquele que começara com um simples prelo chegou a montar o nosso mais belo estabelecimento tipográfico" ${ }^{15}$.

Tanto no primeiro como no segundo capítulo, houve esforço por inserir o jornal e seu editor na dinâmica cultural do Segundo Reinado, buscando entender a ação recíproca de um sobre o outro.

Por fim, não houve como evitar a parte mais difícil da tarefa, que foi a tentativa de estabelecer um perfil estilístico e temático da produção de Machado de Assis para a Marmota. Embora eu tenha cursado os três semestres de Literatura Brasileira normalmente oferecidos pelo CJE aos alunos de Editoração e Jornalismo - por meio do orientador do presente trabalho, Prof. Ivan Teixeira - julgo que, mesmo assim, essa parte permaneceu difícil até o final. Sendo ampla e diversa (poemas de

12. Adolfo Morales de Los Rios Filho, O Rio de Janeiro Imperial, p. 469.

13. Lília Moritz Schwarcz, As Barbas do Imperador, p. 294.

14. Eunice Ribeiro Gondim, Vida e Obra de Paula Brito, p. 12.

15. Manuel Duarte Moreira de Azevedo, "Biografia”, em Poesias de Francisco de Paula Brito, p. XVIII. 
várias espécies, fragmentos dramáticos, ensaios literários, contos e traduções), seria praticamente impossível fornecer um estudo completo dessa matéria.

Havia várias hipóteses sobre o modo de enfrentar o desafio. Uma bastante tentadora seria escolher dois ou três textos e submetê-los a uma análise intrínseca e depois contextual, oferecendo uma visão particularizada dos processos construtivos do autor. Embora interessante, esse tipo de trabalho, além de exigir uma experiência que eu julgo não possuir, poderia oferecer uma visão parcial do conjunto. Outra alternativa seria produzir uma espécie de classificação superficial de todos eles, propiciando algo como uma tabela classificatória. Além de monótona, essa solução pareceu pouco produtiva.

Depois de pensar em como atender a justa solicitação da Profa. Maria Eugênia Boaventura no exame de qualificação, optou-se por uma descrição panorâmica de boa parte da produção, procurando ordenar os textos conforme o gênero e a espécie literária. Assim, a primeira divisão foi entre poesia e prosa. Na poesia, procurou-se dividir os textos entre líricos e paródicos. Entre os líricos, esboçaram-se duas subcategorias: romantismo de sugestão brasileira e romantismo de sugestão portuguesa. No primeiro caso, falou-se também de paisagens da roça, com toques de sentimentalismo tomados a Casimiro de Abreu e outros. No segundo, falou-se em paisagem bucólica, em poemas som sugestões das odes anacreônticas, extraídas de Bocage, Almeida Garrett e Tomás Antônio Gonzaga. Assim, pôde-se perceber que o romantismo do primeiro Machado apropria-se de alguns motivos típicos do arcadismo neoclássico, para o qual contribuem também sugestões de Gonçalves Dias. Foram comentadas outras vertentes temáticas, como a adoção de motivos nacionalistas e religiosos.

Quanto aos textos em prosa, a harmonia do trabalho recomendou rápida notícia sobre a natureza dos mais importantes, como são o conto "Três Tesouros Perdidos", o ensaio "O Passado, o Presente e o Futuro da Literatura", a polêmica sobre "Os Cegos" e a dissertação sobre teatro "Idéias Vagas", entre outros.

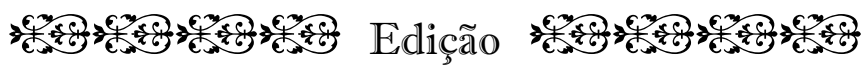

Para a edição dos textos machadianos publicados originalmente na Marmota, optou-se pela diretriz de Antônio Houaiss no capítulo “Originais Modernos", em Elementos de Bibliologia. Nesse trecho o autor afirma que é possível, legitimamente, determinar edições modernas (posteriores ao século XVI) em que a totalidade das normas ecdóticas não seja observada. E sem que a edição perca sua validade científica ou sua fidedignidade. Para isso ele oferece duas soluções: a reprodução facsimilar ou diplomática do texto, ou o estabelecimento de texto idôneo, fidedigno, mas sem todo o aparato propriamente crítico. Para se obter essa matéria fidedigna, há que se levar em conta os seguintes princípios ${ }^{16}$ :

- o texto deve ser obtido de um único exemplar-fonte;

16. Antônio Houaiss, Elementos de Bibliologia, p. 274. 
- deve haver indicação prévia do critério levado em conta para o estabelecimento do texto de base (manifestar quais regras ecdóticas foram seguidas);

- dispensa do aparato crítico indicador de variantes e discrepâncias; mas caso haja variações da mesma lição em edições diferentes, que possam dar margem a interpretações diferentes, é interessante informar.

Nessa mesma obra, Houaiss afirma que "a reprodução diplomática de um texto íntegro é, hoje em dia, fortemente desaconselhada" ${ }^{17}$. E é preciso lembrar que as condições de apresentação gráfica da primeira edição em jornal tornam inviável uma edição fac-similar desses textos machadianos.

Com base nessas informações, elegeu-se para este trabalho o estabelecimento do texto fidedigno. Ainda segundo Houaiss, o trabalho ecdótico para autores mais recentes, do ponto de vista estemático, apresenta as seguintes situações mais comuns ${ }^{18}$ :

- há o manuscrito da obra em estudo;

- há a primeira edição, não sendo conhecido o manuscrito;

- existem os dois elementos, manuscrito e primeira edição.

No caso dos textos de Machado de Assis publicados na Marmota, há notícias somente da primeira edição. Uma vez que, segundo Roger Laufer e Antônio Houaiss, é correto considerar como primeira edição a publicação em jornal. Afirma Laufer em Introdução à Textologia: "Freqüentemente, se faz a primeira publicação de um livro dentro de uma obra coletiva, como por exemplo, um periódico"19; e Houaiss fala em "primeira edição absoluta, mas não em livro"20 e para o primeiro volume aparecido após o periódico, "primeira edição em livro, embora segunda como publicação"21.

Dessa maneira, a base para o estabelecimento dos textos foi o material publicado na Marmota. A maioria das colaborações machadianas nesse jornal foi consultada no Arquivo Edgard Leuenroth (AEL) pertencente ao Centro de Pesquisa e Documentação Social do Instituto de Filosofia e Ciências Humanas, da Universidade Estadual de Campinas (Unicamp) ${ }^{22}$. As demais são provenientes do Real Gabinete Português de Leitura, no Rio de Janeiro

A opção por atualizar a ortografia da edição original, justifica-se principalmente pela necessidade de inteligibilidade, no sentido de adequação à realidade viva do pensamento e da fala do leitor atual, como esclarece Antônio Houaiss ${ }^{23}$. O propósito, portanto, não foi produzir uma edição crítico-filológica. Pois não se trata de texto complexo e obscuro, cuja simplificação ortográfica sem

17. Antônio Houaiss, op. cit., p. 88.

18. Idem, ib., p. 271.

19. Roger Laufer, Introdução à Textologia, p. 121.

20. Antônio Houaiss, op. cit., p. 277.

21. Idem, ib., p. 278.

22. Os microfilmes disponíveis no AEL são provenientes do acervo da Biblioteca Nacional do Rio de Janeiro, assim, as mesmas lacunas são observadas em ambas as instituições

23. Antônio Houaiss, Elementos de Bibliologia, p. 72. 
riscos só poderia ser feita após a apreciação de filólogo. Por fim, as formas "dous" e "cousa" também foram conservadas dos textos originais, como maneira de manter índices textuais da época em que as matérias foram compostas. Antônio Houaiss chama algumas dessas variações do tipo ou/oi, como no caso de "cousa" e "coisa", de "sincretismos regionais, regionalizados ou 'nacionais"'24; e concorda que não devem ser objeto de simplificação ortográfica sem a necessária reflexão.

24. Antônio Houaiss, op. cit., p. 84. 


\section{Capítulo 1}

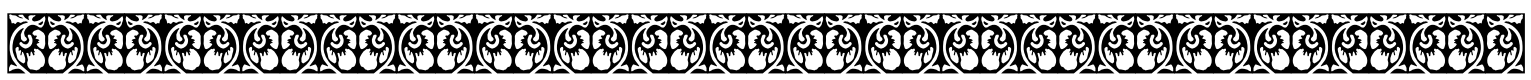 A Marmota

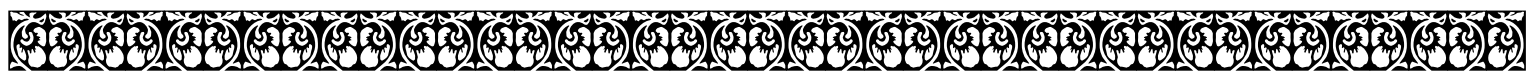

A Marmota foi um jornal de variedades fundado pelo tipógrafo-editor Francisco de Paula Brito em 1849, no Rio de Janeiro. Havia duas edições por semana e circulou de forma sistemática até 1861, sendo certo que houve números esparsos ainda em 1864. Embora o periódico não seja atualmente muito conhecido e nunca tenha sido estudado como importante meio de comunicação do Segundo Reinado, foi em suas páginas que Joaquim Maria Machado de Assis divulgou seus primeiros trabalhos como escritor e jornalista, de maneira ininterrupta, entre 1855 e 1861. Aí, publicou cinqüenta e seis textos. Se todos os trabalhos machadianos divulgados nesse jornal são considerados fundamentais para a compreensão do que se poderia entender como uma espécie de pré-história da formação do escritor, alguns possuem consistência menos relativa e costumam ser citados e estudados como peças importantes de sua produção, como parece ser o caso de "O Passado, o Presente e o Futuro da Literatura Brasileira" e o da tradução Queda que as Mulheres Têm para os Tolos ${ }^{1}$.

Comparada com a grande imprensa do período - constituída, basicamente, pelo Diário do Rio de Janeiro (1821), Jornal do Commercio (1827) e Correio Mercantil (1848) -, a Marmota deve ser considerada um pequeno jornal, cuja principal característica talvez seja a pretensão de atuar diretamente na formação cultural e moral do leitor. Por isso, praticamente desdenha a política e a matéria propriamente noticiosa, privilegiando assuntos supostamente mais perenes, como seriam a literatura, o entretenimento e a moralidade. Além de propor outras formas de possíveis interferências práticas na experiência do leitor pelo oferecimento de figurinos e partituras musicais.

Sobre a grande imprensa da época, Nelson Lage Mascarenhas afirma que o Diário do Rio de Janeiro e o Correio Mercantil se caracterizavam por:

grande tiragem, parte informativa esmerada, seção financeira, comercial, forense, correspondências do estrangeiro, e a substancial seção de anúncios. Com o veterano Jornal do Commercio, eram os de maior circulação, preferidos dos homens sisudos, como se dizia. Os pronunciamentos políticos neles insertos logravam maior penetração, e daí [...] a grande influência que possuíam².

1. Publicados, respectivamente, nos números 941 e 945 (dias 9 e 23 de abril de 1858) e 1.257 a 1.261 (dias 19, 23, 26 e 30 de abril, e 3 de maio de 1861).

2. Nelson Lage Mascarenhas, Um Jornalista do Império (Firmino Rodrigues Silva), p. 282. 
Em uma nota em janeiro de 1854, na qual informa sobre alterações gráficas feitas no Diário de Pernambuco, o próprio Paula Brito chama o Jornal do Commercio de o "gigante do Rio", comparando-o ao primeiro, que seria o "gigante de Pernambuco"3. Ambos, nas palavras do tipógrafo, eram órgãos dedicados à política e aos progressos materiais.

\section{7\% Esbos Românticos}

Como se sabe, desde o momento da descoberta do Brasil e durante todo o processo de conquista e colonização portuguesa, ocorreu o transplante de língua e literatura já maduras para um novo território, habitado por outros povos, possuidores de modelos culturais totalmente distintos do conquistador. Desse modo, a sociedade colonial caracterizou-se pela transposição de leis, costumes e tradições vindos da metrópole.

A literatura "brasileira", como resultado dessa imposição cultural, atuou inicialmente como instrumento colonizador, pois divulgou os valores cristãos e a noção metropolitana de vida social, consolidando não somente a presença de Deus e da monarquia, mas igualmente a exclusividade da língua na colônia.

A partir da Independência, segundo Bernardo Ricupero, estabeleceram-se, nas antigas colônias portuguesas e espanholas, Estados que tomaram como referência a organização política vigente na Europa e América do Norte. No entanto, as instituições políticas e jurídicas não criaram para essas populações recém-independentes referências culturais de pertencimento. No lugar das metrópoles coloniais, os países da América Latina adotaram como referencial intelectual a França. Essa influência não se constituiu em simples modismo, fundou-se primeiramente na similaridade entre os problemas intelectuais enfrentados por latino-americanos e franceses, ambos, de certo modo, reagiam ao fim do Antigo Regime ${ }^{4}$.

O romantismo, em ambos os lados do Atlântico, foi uma tentativa de colocar um fim às antigas configurações políticas, estéticas e de pensamento, e ao mesmo tempo substituí-las por novas formas. Nessa nova proposta, a idéia de nação mostrou-se essencial para a concretização das aspirações de ruptura com o passado. Enquanto na Europa viviam-se os últimos dias da sociedade feudal, na América era a estrutura colonial que chegava ao seu fim.

Nos anos posteriores à Independência do Brasil, coube aos homens da época a tarefa de completar a emancipação política do país em formação, dotando-o de maior autonomia cultural. Simultaneamente, na esfera cultural européia, testemunhou-se a passagem do predomínio das idéias das luzes para as românticas, que buscavam fortalecer o caráter nacional de sua literatura e historiografia. Sob influência do pensamento romântico europeu, a elite intelectual do Segundo Reinado também passou a considerar condições necessárias para a existência de nação, a literatura e a historiografia do Brasil.

3. Marmota Fluminense, n. 437, p. 1, 20 jan. 1854.

4. Bernardo Ricupero, O Romantismo e a Idéia de Nação no Brasil (1830-1970), pp. 45-80. 
Assim, tudo o que até então havia sido produzido em território brasileiro adquire um sentido retrospecto. Entendia-se que antes dos românticos existiu literatura produzida por escritores nascidos no Brasil, mas não propriamente literatura brasileira como matéria consciente. Ironicamente, no entanto, o movimento literário que mais enfatizou a autonomia intelectual não foi iniciado por brasileiros, pois tanto a crítica como a historiografia românticas foram fundadas por estrangeiros: o francês Ferdinand Denis, os ingleses Robert Southey e John Armitage, e o bávaro Karl Friedrich Phillip von Martius 5 .

Em seu Résumé de l'Histoire Littéraire du Portugal, Suivi du Résumé de l'Histoire Littéraire du Brésil, publicado em 1826, Ferdinand Denis já indica a necessidade de realizar a independência literária do Brasil:

O Brasil, que sentiu a necessidade de adotar instituições diferentes das que lhe havia imposto a Europa, o Brasil experimenta já a necessidade de ir beber inspirações poéticas a uma fonte que verdadeiramente lhe pertença; e, na sua glória nascente, cedo nos dará as obras-primas desse primeiro entusiasmo que atesta a juventude de um povo ${ }^{6}$.

Neste trabalho pioneiro de Denis já surge um dos temas mais recorrentes do romantismo brasileiro: após a independência política, é preciso realizar a independência literária. Se anteriormente o Brasil era meramente um fornecedor de riquezas, sem partilhar as glórias da metrópole, como nação independente, era necessário ter vida autônoma e superar as formas de pensamento estabelecidas durante o colonialismo. A literatura teria que procurar ser original, rejeitando os elementos que não estivessem de acordo com a nova nação - seu clima, natureza e tradições. É nesse contexto que Denis sugere a inspiração nos povos exterminados pelos colonizadores, "a recordação de sua grandeza selvagem cumulará a alma de orgulho, suas crenças religiosas animarão os desertos; os cantos poéticos, conservados por algumas nações, embelezarão as florestas"7. Trata-se de uma sugestão ao programa indianista, que tanto marcará o romantismo no Brasil.

Almeida Garrett, introdutor da escola romântica em Portugal, insistiu igualmente na necessidade de autonomia da literatura produzida no Brasil. Em seu Parnaso Lusitano, editado também em 1826, ele lamenta o apego dos poetas brasileiros às inspirações européias:

E agora começa a literatura portuguesa a avultar e enriquecer-se com as produções dos engenhos brasileiros. Certo é que as majestosas e novas cenas da natureza naquela vasta região deviam ter dado a seus poetas mais originalidade, mais diferentes imagens, expressões e estilo, do que neles aparece; a educação européia apagou-lhes o espírito nacional: parece que se receiam de se mostrar americanos; e daí lhes vem uma afetação e impropriedade que dá quebra em suas melhores qualidades ${ }^{8}$.

5. Bernardo Ricupero, op. cit., pp. 85-87.

6. Ferdinand Denis, "Resumo da História Literária do Brasil”, em Guilhermino César (org.), Historiadores e Críticos do Romantismo, p. 36.

7. Idem, ib.

8. Almeida Garrett, “A Restauração das Letras, em Portugal e no Brasil, em Meados do Século XVIII”, em Guilher- 
Somente dez anos após os trabalhos pioneiros de autores estrangeiros que os intelectuais brasileiros abraçam definitivamente a causa da independência literária. A primeira dessas manifestações nacionalistas foi Niterói - Revista Brasiliense de Ciências Letras e Artes, publicada em 1836, curiosamente, em Paris. À frente do periódico estavam os então jovens Domingos José Gonçalves de Magalhães, Manuel Araújo Porto-Alegre e Francisco de Sales Torres Homem.

O periódico era voltado para estudos de economia política, ciências, literatura nacional e artes. Segundo Ricupero, Niterói insere-se em um quadro maior de publicações que, antes e depois dela, procurarão usar a cultura com objetivos práticos, de promoção do progresso material. Ou seja, nesse tipo de revista as motivações literárias estão subordinadas a outras considerações?.

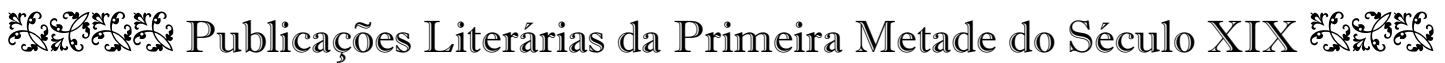

Com o objetivo de inserir a Marmota em uma certa tradição de publicações literárias no Brasil, buscou-se traçar um breve histórico das principais revistas desse gênero aparecidas a partir da instalação da Impressão Régia no país, em 1808.

Embora o primeiro órgão oficial brasileiro, a Gazeta do Rio de Janeiro, tenha transcrito alguns textos clássicos, o primeiro jornal declaradamente voltado à literatura foi As Variedades ou Ensaios Literários, publicado na Bahia em 1812 e de pouca expressão ${ }^{10}$.

O Patriota, que circulou no Rio de Janeiro entre 1813 e 1814, inaugurou definitivamente a revista de cultura no Brasil ${ }^{11}$. Esse periódico não apenas abriu caminho às demais publicações científico-literárias, como também divulgou liras inéditas de Tomás Antônio Gonzaga. Circulou também na capital do Império O Beija-flor: Anais Brasileiros de Ciência, Política, Literatura, entre 1830 e 1831, divulgando textos noticiosos, políticos, literários e de interesse geral.

Em 1833 foi criada a Revista da Sociedade Filomática, iniciativa de professores e acadêmicos da recém-fundada Faculdade de Direito de São Paulo, que durou seis números e se extinguiu no mesmo ano de seu surgimento. $\mathrm{O}$ artigo-manifesto da folha revelava a preocupação de seus diretores com a promoção do avanço literário da nação. Eles desejavam desligar-se da imitação dos antigos, em nome da razão e do bom gosto. Entendiam a literatura como "expressão colorida do pensamento da época", o que lhes parecia suficiente equilíbrio entre a renovação que demandavam e o apego aos princípios da natureza. No entanto, boa parte de seus discursos ainda revelava elementos clássicos, uma forma de manutenção dos velhos processos ${ }^{12}$. Entre os colaboradores da folha estavam Francisco Bernardino Ribeiro e Justiniano José da Rocha.

A já mencionada Niterói, de 1836, buscava lutar contra o desnivelamento cultural existente entre o Brasil e os países do Velho Mundo:

mino César, op. cit., p. 90.

9. Bernardo Ricupero, op. cit., pp. 91-92.

10. Carlos Rizzini, O Livro, O Jornal e a Tipografia no Brasil, p. 167.

11. Nelson Werneck Sodré, História da Imprensa no Brasil, pp. 35-37.

12. Hélio Lopes, A Divisão das Águas, pp. 14-16. 
O amor do país, o desejo de ser útil aos concidadãos determinaram os autores à empresa de fundar a revista. A necessidade de uma obra periódica que fizesse os concidadãos "refletir sobre os objetos do bem comum e da glória da pátria". Tal é o fim a que se propõem os autores dessa Revista, reunindo todas as suas forças para apresentar em um limitado espaço considerações sobre todas as matérias, que devem merecer a séria atenção do brasileiro amigo da glória nacional [...]. As ciências, a literatura nacional e as artes vivificam a inteligência, animam a indústria e enchem de glória e de orgulho os povos que as cultivam, não serão de nenhum modo negligenciadas. E destarte, desenvolvendo-se o amor e a simpatia geral para tudo que é justo, santo, belo e útil, veremos a pátria marchar na estrada luminosa da civilização e tocar ao ponto de grandeza que a Providência lhe destina ${ }^{13}$.

Gonçalves de Magalhães, um dos idealizadores da revista, foi quem assumiu o posto de introdutor do romantismo no Brasil com a publicação de Suspiros Poéticos e Saudades, no mesmo ano de Niterói. O prefácio da obra oferece o programa da reforma literária mencionado na folha: poesia de impressões pessoais, carregada de individualismo, poesia de imaginação com predomínio do lúdico sobre o racional; poesia cristã no lugar de ficções mitológicas; poesia tumular: fuga, devaneio, amor, saudade; poesia patriótica: revolta contra as arbitrariedades despóticas, ideal das liberdades humanas, exaltação do heroísmo, busca pelas tradições nacionais, enfim, oposição ao universalismo clássico.

No mesmo ano de Niterói, foi criado O Cronista, no Rio de Janeiro, por Justiniano José da Rocha, que circulou até 1839. Embora o jornal apresente grande importância para o estudo da história política, é igualmente de interesse para a análise da implantação do romantismo no Brasil, pois era mais próximo da população que a Niterói, por exemplo, além de ter apresentado maior durabilidade. Justiniano busca com sua folha instituir no Brasil a nova escola, adaptando o gosto do público para as manifestações românticas por meio de dois instrumentos: críticas e adoção do folhetim literário ${ }^{14}$.

Entre 1843 e 1845 esteve ativa A Minerva Brasiliense, um jornal de ciências, letras e artes dirigido por uma associação de literatos. O sucesso do periódico pode ser atribuído aos seus colaboradores, os nomes mais afamados de vários campos das ciências, desde medicina, botânica e zoologia até geografia, química e astronomia. A variedade dos assuntos abordados também foi um grande atrativo. Apesar de o jornal não ter tomado nenhuma posição declarada com relação à literatura, os vários estudos de revisão do passado com o objetivo de descobrir, afirmar e provar a existência de uma literatura nacional, marcam a existência dessa preocupação. O periódico ainda levou a cabo a publicação de diversas obras literárias na sua coleção Biblioteca Brasílica, sendo o inaugurador da iniciativa.

Hélio Lopes lembra que a Minerva Brasiliense foi o primeiro periódico científico-literário nascido após a Maioridade de D. Pedro II, o que significou um maior distanciamento entre literatura e política na imprensa em geral. O autor ainda comenta:

13. Niterói, n. 1, pp. 5-6, 1836 apud Hélio Lopes, op. cit., p. 22.

14. Hélio Lopes, op. cit., pp. 24-28. 
Cresce e forma-se, alheia ao grupo da Minerva, a segunda geração romântica. Um mulato extraordinário, Francisco de Paula Brito, parece estabelecer ponte de ligação entre estes mestres e doutores e próximos viscondes, com indivíduos marginalizados e desconhecidos pelos donos da Minerva Brasiliense. Um deles: Martins Pena. Outro, colaborador da revista, teimoso fabricador de livros e morto na miséria, Antônio Gonçalves Teixeira e Sousa ${ }^{15}$.

Em 1848, apareceram no Brasil dois novos periódicos literários: Íris, revista de religião, belasartes, ciências, letras, história, poesia, romance, notícias e variedades (1848-1849), e Museu Pitoresco (1848). A primeira, criada por José Feliciano de Castilho, pretendia ser um elo literário entre Brasil e Portugal, no que aparentemente não logrou grande sucesso. Contava com colaborações de PortoAlegre, Joaquim Manuel de Macedo, Joaquim Norberto de Sousa e Silva e Antônio Gonçalves Dias ${ }^{16}$. O Museu Pitoresco foi uma revista semanal dos irmãos Laemmert, ricamente ilustrada com gravuras em metal vindas da Europa ${ }^{17}$. A revista dedica-se essencialmente à divulgação de ficção européia, mas traz como inovação contos holandeses e russos.

O Beija-flor: Jornal de Instrução e Recreio circulou entre 1849 e 1850, era semanal, distribuído aos sábados, declaradamente sem grandes pretensões intelectuais além do entretenimento. Em uma de suas matérias, "Os Jornais" de José Dias da Costa, se comenta a efemeridade dos periódicos literários brasileiros:

Não sabemos que mau fado preside a fatal sina destes pequenos jornais que hoje se publicam, e a quem mesmo por modéstia chamaremos literários [...]. O que é sabido, e por todos reconhecido, é que a aparição de tais jornais tem unicamente a duração de um relâmpago: fulgem e desaparecem. Todos começam em seus prólogos por dizer que não querem adquirir reputações literárias [...]. Com tudo isto, sua vida é efêmera, pois que apenas começam a andar, eis que lhe(s) sobrevém a morte, tendo por sepultura alguma loja de confeiteiro, e por epitáfio: Muito viveu ele! Tal é a esperança e mesmo os exemplos! [...]. Mas não obstante tudo isto, os campeões correm à liça aos cardumes $[\ldots]^{18}$.

Como seu próprio artigo sentenciou, O Beija-flor foi outra folha que teve curta duração, no entanto, cumpriu seu papel, publicou contos de Joaquim Norberto, prosa de autores brasileiros, bem como muita poesia.

Entre 1849 e 1856 esteve em circulação do Rio de Janeiro O Guanabara - Revista Mensal Artística, Científica e Literária. Inicialmente, seus redatores foram Porto-Alegre, Joaquim Manuel de Macedo e Gonçalves Dias e, posteriormente, o cônego Joaquim Caetano Fernandes Pinheiro. Após alguns problemas com a primeira oficina, O Guanabara passou a ser impresso na Tipografia da Empresa Dous de Dezembro, de Paula Brito, de onde também saía a coleção de obras Biblioteca

15. Idem, ib., p. 35 .

16. Idem, ib., pp. 43-45.

17. Orlando da Costa Ferreira, Imagem e Letra, p. 435.

18. O Beija-flor, v. I, n. 5, pp. 1-2, mar. 1849 apud Hélio Lopes, op. cit., pp. 48-49. 
Guanabarense. A revista sofreu algumas longas interrupções em sua publicação, por conta disso, depois de 1854, D. Pedro II tomou-a sob sua proteção ${ }^{19}$.

Nessa folha foram divulgados vários textos críticos, muitos dos quais sem a assinatura do autor. Outros, além de serem assinados, debatem idéias e buscam indicar um caminho para a literatura e as artes brasileiras, como: o ensaio "Resposta à Religião", de Gonçalves Dias; "Retrospecto Literário", de Joaquim Caetano Fernandes Pinheiro; "A Língua Brasileira”, de Joaquim Norberto; e os dois ensaios intitulados "Algumas Idéias sobre as Belas-Artes e a Indústria no Império do Brasil”, de Araújo Porto-Alegre.

Hélio Lopes julga que o principal defeito da publicação, que contribuiu para o seu final, foi "ter-se fechado em um círculo de pequenos medalhões". Não tomando conhecimento do que acontecia fora de sua roda, ignorando talentos contemporâneos como Bernardo Guimarães, Álvares de Azevedo, Casimiro de Abreu, Martins Pena e Manuel Antônio de Almeida ${ }^{20}$.

Como os periódicos anteriormente mencionados, a Marmota, não dispondo de instrumental técnico nem de recursos humanos para a produção de um discurso que pudesse interferir nos destinos políticos do país, limitava-se a apoiar o imaginário do Segundo Reinado, então já francamente consolidado nas diversas camadas simbólicas do discurso oficial do Império Bragantino no Brasil. Dedicava-se, desse modo, a difundir a educação e a aumentar a cultura de seus leitores.
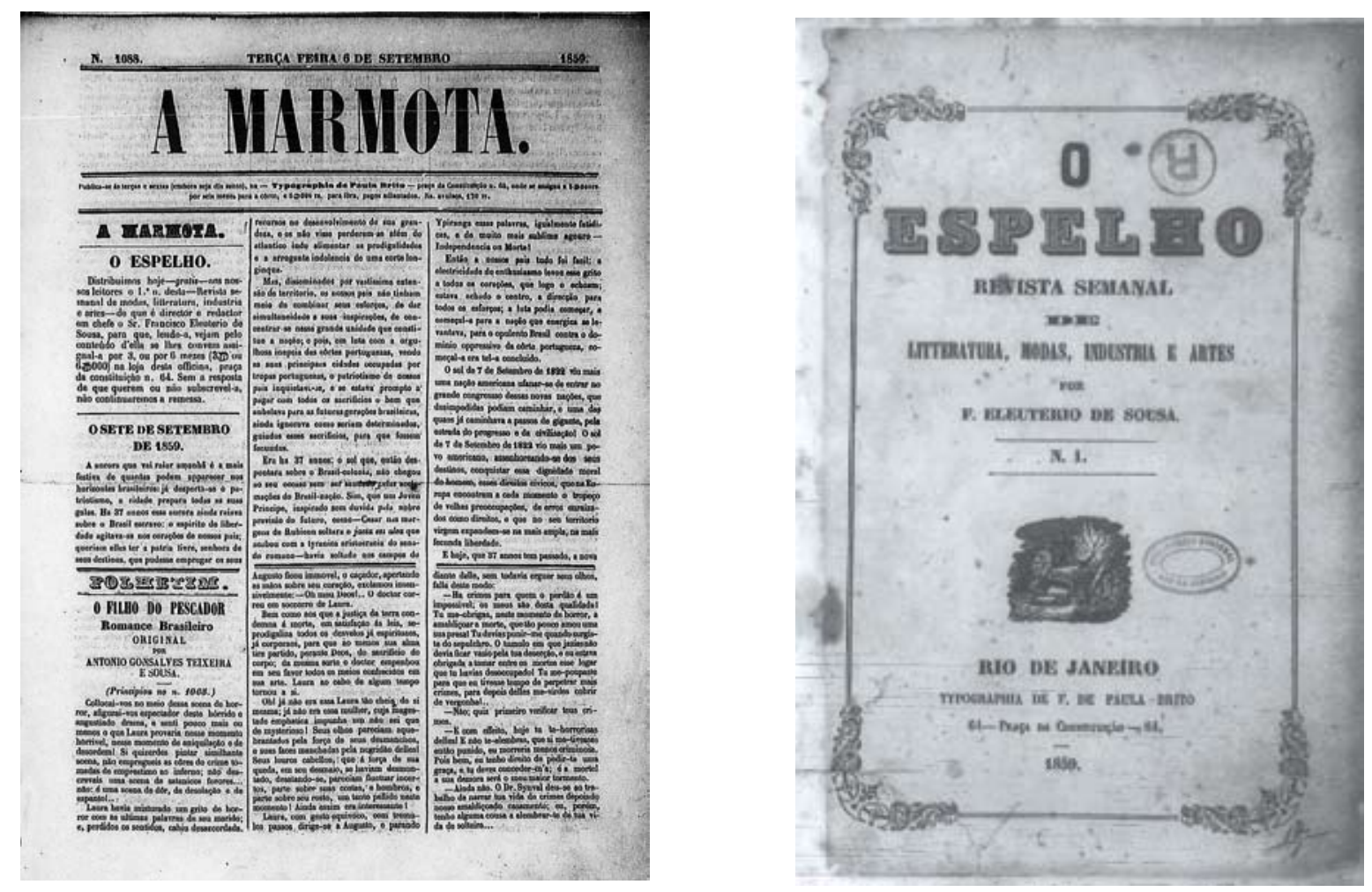

Figura 1. A Marmota de setembro de 1859 que anunciava o primeiro número de O Espelho.

19. Hélio Lopes, op. cit., pp. 53-68.

20. Idem, ib., p. 68. 
A diretriz da Marmota perdurou ainda após na segunda metade do século XIX. Em 1859, dez anos após a fundação da revista de Paula Brito, era distribuído com ela o primeiro número de $O$ Espelho - Revista Semanal de Literatura, Modas, Indústria e Artes, que já revela grande similaridade com a Marmota ${ }^{21}$. No exemplar inaugural de O Espelho, Francisco Eleutério de Sousa, seu redator, informa que sua intenção é "torná-la [a revista] variada, mas de uma variedade que deleite e instrua, que moralize e sirva de recreio quer nos salões do rico, como no tugúrio do pobre"22.

A afinidade com a Marmota vai além da proposta de ser um periódico de variedades: ainda no texto de apresentação de $O$ Espelho, Eleutério de Sousa afirma que serão publicados na revista romances originais ou traduzidos, artigos sobre literatura, poesias e "tudo quanto possa interessar ao nosso publico e especialmente ao belo sexo". Ainda promete novidades sobre modas e, futuramente, a distribuição de figurinos - vindos de Paris - e de gravuras. Com a mesma proposta de Paula Brito, Eleutério de Sousa informa que as colunas de sua revista estão abertas aos talentos da mocidade. Além dessas semelhanças, pode-se contar também os colaboradores que os periódicos tiveram em comum, começando por Francisco Eleutério de Sousa, que colaborava na Marmota. E já no primeiro número de $O$ Espelho constam Machado de Assis, Moreira de Azevedo e o próprio Paula Brito.

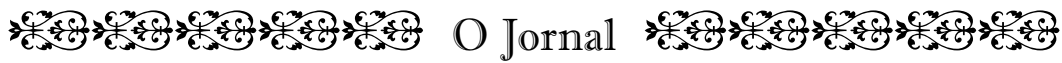

Por Marmota entende-se, neste texto, a unidade formada pelos três títulos que o periódico ostentou: A Marmota na Corte (1849-1852); Marmota Fluminense (1852-1857) e A Marmota (18571861 e 1864). Apesar dos nomes distintos, a diretriz editorial conservou-se essencialmente a mesma, hipótese que pode ser confirmada pela presença constante de Francisco de Paula Brito em sua direção ${ }^{23}$, pela regularidade dos números do jornal (que permaneceram contínuos mesmo com a troca de nomes) e pela denominação de sua primeira coluna, "A Marmota", que continuou sempre a mesma (e que exercia, em termos atuais, função semelhante a um editorial).

É conveniente, no entanto, apontar algumas peculiaridades de cada fase do periódico. A primeira teve como principal redator o baiano Próspero Diniz, que, mesmo deixando a capital do Império no final de 1849, continuou colaborando no jornal até seu falecimento, em 1852. Esse período é marcado pelas crônicas - com certo teor denúncia - registrando inconvenientes na cidade do Rio de Janeiro, como a falta de pároco em determinado bairro, o atoleiro que se formou em alguma rua, o estado de deterioração de certos edifícios etc. Pode-se verificar também a grande quantidade de correspondências, endereçadas ao redator, divulgadas no jornal. Percebe-se a presença da seção de entretenimento e de um pequeno espaço destinado aos versos.

Na segunda fase, Paula Brito passou a ser o principal redator, além de permanecer como responsável pela direção do jornal. Nesse momento, há um incremento substancial de área impressa

21. A Marmota, n. $1.088,6$ set. 1859.

22. O Espelho, n. 1, p. 1, 4 set. 1859.

23. Com exceção dos números saídos em 1864, pois o tipógrafo faleceu em dezembro de 1861. Sua viúva e genro deram continuidade aos trabalhos da oficina. 
destinada à literatura. Além da poesia, agora se publica igualmente a prosa. Com a melhora do aproveitamento do espaço gráfico, resultado das três colunas de texto, o tipógrafo decide criar em seu periódico a seção literária “Folhetim”, que ocupa a porção inferior da página. Como já mencionado, foi Justiniano José da Rocha quem introduziu o folhetim literário no Brasil em seu periódico O Cronista, em 1836. Na França, essa seção era conhecida como feulleton, na falta de uma tradução adequada, Justiniano inicialmente chamou-a "folhas" e ainda "apêndice" 24

A Marmota, nessa segunda fase, traz menos correspondências e notícias da cidade, embora o espaço do divertimento permaneça o mesmo. O período é também marcado pela solidificação dos negócios da Empresa Dous de Dezembro criada por Paula Brito, mediante investimento de acionistas, que conta com tipografia, litografia, estamparia e oficina de encadernação. Em 1852 aparece o primeiro trabalho impresso pela oficina litográfica, a valsa "Júlia" distribuída com a Marmota ${ }^{25}$. A partir desse momento, as páginas do jornal serão mais adornadas, trazendo mais ilustrações e caricaturas. Também serão oferecidos mais figurinos e gravuras para os assinantes do periódico, pois, até então, esses trabalhos ilustrados eram feitos em outras empresas.

O último momento da Marmota conserva a ênfase literária do jornal e é assinalado pela liquidação da Empresa Dous de Dezembro. Logo no início de 1857, antes da troca do nome da folha que se daria em julho, Paula Brito emitiu uma circular pedindo aos leitores que tentassem ampliar o número de assinantes da revista, pois com os recursos de que dispunha do momento, não era possível manter o periódico ativo:

[...] a Redação pede a V. Ex. ${ }^{a}$ se digne a aumentar o número de subscritores com os nomes de alguns amigos e pessoas da sua confiança, sem o que a publicação será infalivelmente suspensa, vindo assim a ter este jornal literário e recreativo, e que tão a peito tem tomado a causa das Senhoras, a sorte mesquinha de tudo quanto é trabalho de inteligência no nosso país, e isto depois de - nove anos - de existência ${ }^{26 !}$

Após esse apelo, o tipógrafo ponderou que a única alternativa era cessar a publicação e comunicou essa decisão aos seus leitores em maio de 1857: "Circunstâncias imperiosas nos obrigam a suspender a publicação da Marmota". O tipógrafo reconheceu que por pouco importante que fosse uma folha periódica, redigi-la era sempre uma tarefa laboriosa que não podia ser feita quando "o espírito se acha embotado pelo choque de contínuas decepções" ${ }^{27}$. Ele ainda asseverou que os assinantes continuariam a receber o Moderador e caso houvesse insatisfação pelo saldo relativo à Marmota, procuraria indenizá-los de alguma forma.

No entanto, os planos do tipógrafo não foram adiante: "A queda do Ministério trouxe a cessação do Moderador, folha ministerial, e somos por isso forçados a continuar a Marmota até o

24. Hélio Lopes, op. cit., p. 28.

25. Marmota Fluminense, n. 298, 21 set. 1852.

26. "Circular", Rio de Janeiro, 25 mar. 1857.

27. Marmota Fluminense, n. 843, p. 4, 1 maio 1857. 


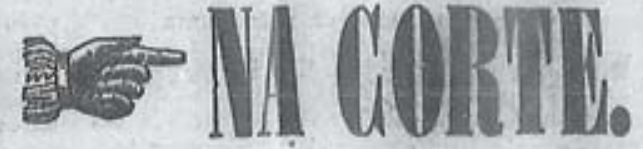

Publica-so is Teryes o Sexiss felras, na Typ. de Pauba Barro, ras dos Oarives n. 81, onde se receben assizastaras a g0000 rs. per 25 numeros, pagos seaupre adiaatades. Namo-

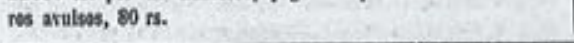
res arultos, $80 \mathrm{rs}$.

\section{A IMARMMGA}

\section{Vista agradavel!}

Acham-se finalmente reimpressas as Marmotas! As pessoas que agora quizerem - colleccóes completas - podem procural-as nas lojas do editor, rua dos Ourives n. 21, praça da Constituição n. 64, e Nictheroy, largo municipal n. 2, onde uricamente se vendem, (e tambem na rua da Imperatriz n. 10).

Os Snrs. Assignantes, eujos nomes serảo depois publicados em supplemento, hajam do mandar receber os numeros que lhes faltam, segundo as notas constantes dos seus recibos.

0 Redactor tem GRANDES VISTAS a respeito da continuaçáo da Marmota, baseado no geral acollimento que do publico recebe todos os dias, e de todas as provincias do Imperio.

\section{Vista analyitica, e lastimosa.}

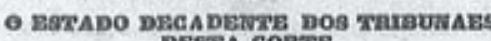
DESTRA CORTE.

Ha poneos dias fomos ver a Bibliotheea Publica, a qual, eomquanto esteja bem sortida de lirros, e enIro esses vissemos obras muito raras o prociosas, e nEo obstante estar aquelle estabelecimento dirigido por um habil administrador o Snr. Dr. Josb do Assis Alves Braneo, moço incontestavelmente digno de estar no numero dos mais talentosos do Brasil; a easa ondo so fandou a Bibliotheca ô bem impropria para aquello fim, a posigso ondo está collocada é má, os saloss șīo tristes a escuros : o tendo alguma commodidade, esta A mal dividida, porquo dependo de eseadas esquisitas para so sobir a um alȩapio ou segundo andar; do sorta que pareces-mo a Bibliotheea uma ratoeira grande, e ainda mais por eonservat a morrinlas de frades velhos; aquella casa, pola sua tristeza, a mois propria para peniteneia do que para o recroio da leituro.

Na quinta feira passada, tondo ou do entregar uma carla que me remolteram da Bahia para o Snr. Antonio da Costa Miranda, indagando onde poderia eneontrar esto senhor, disseraim-mo que no Thesouro Nacional; porguntoi onde era esse Thesouro, apontarameme para uma casa muito suja, com vistas de palacio abandenado i entroi pela parte de

\begin{tabular}{|c|c|}
\hline Eis a Masuora & Falla a verdede, \\
\hline Bem variala & Dir o qeo sente, \\
\hline Pra ser de todos & Ans o respeita \\
\hline Sempre estimada. & A toda gente. \\
\hline
\end{tabular}

frente, subi uma escada preta, e depois de pasar por um corredor estreito o onfumachdo, achei em uma pequena sala, ornada do téas do aranba, uma multula de empregados apinhados em umas mests accummuladas do papeis; táo atordoado fiquei do ver tanta gento junta em tăo pequeno convez, que pez-mo a catar o Snr. Miranda para lhe entregar a carta ; eis sendo quando, ollo me conbecendo, gritou de um canto do uma mesa: - aqui estou $!-0$ tou de um canto do uma mesa: - aqqui cstou!-
era tal o atravaneo da tenda, que me foi precise estender o braco para entregar a carta, porque o oaminho ou trilho por ondo to passa estava tapado com as pennas dos empregados; finalmente, dopois que me estirei muito o o Snr. Miranda estendou o braço tambem, e ficou a carta entregue, o de lá voltei benzendo-me do estado miserabilissimo em que esth a mais importanto casa da corte do nosso imporio! Os émpregados daquolla casa sfo som duvida mais mal hospedados do que os prosos da cadeia, porque alem da tristonha vista do interior, do vez om quando sfio obsequiados com um defumador do carvâo do podra nos dias em que a casa da moeda faz suas fundiçбes, ou outras operaçoes do fogo.

la-me osquecendo fallar nos lampeóes dos corredores que sío de muito gosto, todos elles ricamonto pintados do borra do azeite, tendo alem dísto a belleza do soltarem alguns piagos sobro as pessoas qua passam por baixo!

Ora, na verdade, digamos sinceramente, - quo idéa farà um estrangeiro observador que pela prioneira vez chegar a corte do Brasil ! ! !

Logo ao saltar om terra, nấo acha um caes porfoito, por conseguinto hado trepar por eseadas sem degráos, o so for de noito hade refrescar o nariz com o vapor dos tigreg; so em seguimento for apresentor seu passaporto a Policia, tein de ver uma sala esmolambada ; se for â praça do Commercio, pode assnstar-se pensando que esta dentro do algum semiterio; se em continuaçẩo vai ao clamado Thesouro, pensando achar una casa aceiada o explendida, quo condiga coin o nome e riquoza que guarda, eacoatra um easeo de edificio sujo so proprio para doposito do lentias do uma paderial

O governo tem deixado om nbandono as estacōos publicas ; o beut certo estou quo so S. M. o Imperador entrasse prosentemente no Thesouro, a lançasse uma liggeira vistn sobró aquellas paredos, o miserin da toda a casa, munderia som demorn fazer, so tnenos, uma roforma do aceio para os fisfalizes amprogados nî̀o respirarem em uma babilaçăo quo so vai toranndo ate prejudicial a saude.

Figura 2. Primeira página de $A$ Marmota na Corte de 16 de novembro de 1849. Inicialmente o jornal apresentava duas colunas de texto. 
fim do corrente semestre. É mais uma contrariedade!"28. Na mesma nota, Paula Brito ainda agradecia aos colegas da imprensa pelo interesse demonstrado em relação aos seus problemas e do mesmo modo reconhecia os esforços de pessoas que estavam agenciando assinaturas de sua revista em outras cidades.

Pouco depois, Paula Brito sentenciou que a Marmota continuaria, pois ele havia cedido sua posição de redator a um amigo - que pretendia trazer algumas matérias políticas para a folha - de modo a delegar uma parte de suas tarefas. Confirma que ainda estaria presente na publicação, mas "limitando-se a nossa humilde pena, e a de nossos dedicados amigos [...] àqueles artigos facetos de que ela sempre trará a mais escolhida e conveniente porção, além dos folhetins e transcrições de costume"29.

No décimo aniversário da Marmota, em seu editorial que recorda brevemente uma parte do trajeto percorrido por sua revista, Paula Brito noticia que periódico acabara de ganhar um benfeitor, mas não revela seu nome, e apenas transcreve um trecho do que parece ser uma correspondência enviada por este "protetor":

Sexta-feira 9 de setembro próximo futuro completa a Marmota - dez anos - de existência. Por vós tem ela vivido até hoje; acho, porém, que ela seria por demais exigente se continuasse a querer sustentar uma vida, que só a vós é cara.

Se depende de tão pouco a vida da Marmota - viva. Faça os seus - dez anos - descansados e sobre esses conte mais cem, para levar à posteridade o nome de seu proprietário e redator em chefe.

Seria uma cousa digna de ver-se a Marmota com 110 anos de vida! Só por isso eu desejaria ressuscitar ${ }^{30} ! \ldots$

Ainda em 1859, há uma notícia comentando sobre a mais nova presença na redação da folha, Bruno Seabra, que menciona novamente esse protetor: "Como não poupamos esforços para tornar esta folha digna da proteção que se lisonjeia de bem receber [...]"31.

As colaborações de Machado de Assis distribuem-se entre a segunda e a terceira fases da revista, respectivamente Marmota Fluminense e A Marmota.

Sobre o título do jornal, é interessante lembrar que o vocábulo marmota, além de designar um roedor quadrúpede, é sinônimo de espantalho e fantasma. Como se trata de um periódico que se caracteriza como "joco-sério"32 - pois buscava, de certo modo, moralizar por meio da riso - e como possuía feições de publicação um tanto primitiva, pode-se pensar que seu nome sugeriria algo desajeitado, assombroso, semelhante a um espantalho ${ }^{33}$.

28. Marmota Fluminense, n. 844, p. 1, 5 maio 1857.

29. Idem, n. 853 , p. 1,5 jun. 1857.

30. A Marmota, n. 1.089 , p. 2, 9 set. 1859.

31. Idem, n. 1.101, p. 1, 21 out. 1859.

32. Idem, n. 1.129, p. 1, 27 jan. 1860.

33. Mencionando-se apenas o ano de 1849, o "Índice Cronológico dos Jornais de Revistas Cariocas" - de Gondin da Fonseca, em Biografia do Jornalismo Carioca - apresenta uma série de títulos curiosos que dão a tônica da época para a pequena imprensa: Conde de Paus ou Testamento de Judas, O Desengano dos Papeletas, O Diabo no Mundo, O Judas, 


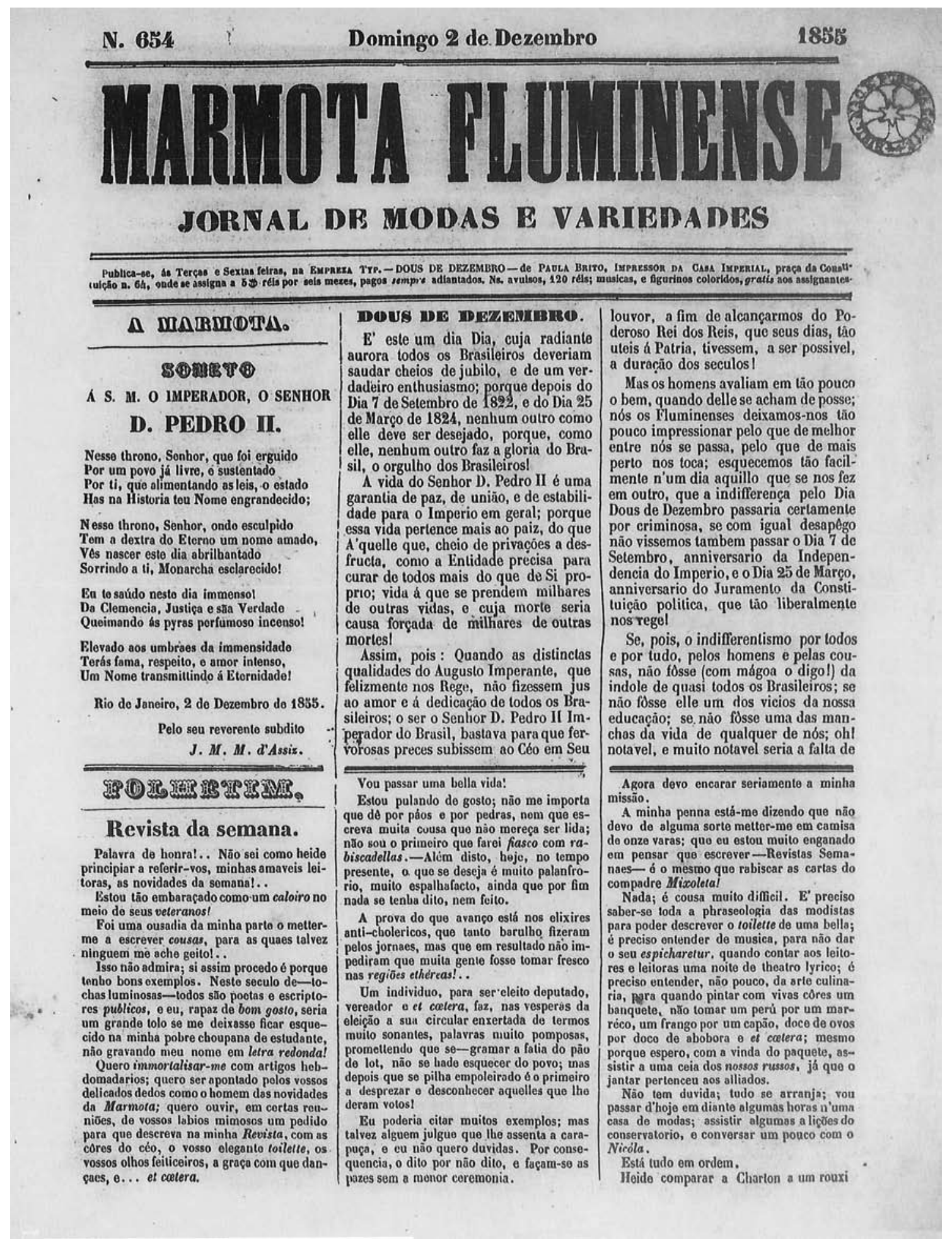

Figura 3. Primeira página da Marmota Fluminense de 2 de dezembro de 1855. 0 jornal nessa fase era composto por três colunas de texto e apresentava o folhetim na porção inferior da página. O exemplar reproduzido traz as homenagens de Machado de Assis e de Paula Brito ao natalício do imperador. 
No século XIX, o sentido do termo marmota igualmente abarcava um tipo de brinquedo ótico, conhecido como cosmorama ou lanterna mágica, que consistia em uma caixa simples em cujo interior eram projetadas imagens distorcidas por espelhos ${ }^{34}$. Na primeira metade dos Oitocentos, além da publicação de Paula Brito, ainda vieram a público outros periódicos cujos nomes aludiam a esse tipo de divertimento, como O Cosmorama Judicial (1836), A Lanterna Mágica (1844) e O Cosmorama na Bahia (1849). Tomando-se por base um pequeno trecho de uma matéria publicada na Marmota, talvez as intenções subjacentes ao seu nome realmente tenham mais ligação com o cosmorama: “[...] firme no seu posto, bicho dos Alpes, ou câmara ótica, a Marmota continuará a ser vigilante atalaia dos interesses do povo, das letras, da ciência, do comércio, da indústria e das artes" ${ }^{35}$.

Ainda com relação ao título do jornal, circulou no Rio de Janeiro, entre fevereiro e agosto de 1833, outro periódico chamado Marmota, redigido por Pascoal Bailão. Um veículo de orientação restauradora, classificado por Hélio Vianna como "um dos mais violentos pasquins do Rio de Janeiro"36 e que não tem relação alguma, exceto pela semelhança de títulos, com o objeto de estudo do presente texto. O mesmo vale para outro carioca, A Marmota - Periódico Satírico e Engraçado, do qual há dois números conhecidos, de março de 1849, impressos na Tipografia Silva e Lima ${ }^{37}$.

A Marmota de Paula Brito era bissemanal, circulava normalmente às terças e sextas-feiras, com quatro páginas, no formato $32 \times 23 \mathrm{~cm}$ (que chegou a apresentar variações). Inicialmente, ela era formada por duas colunas de texto; a partir de 1852, foram estabelecidas três. Não havia nomes definidos para as seções, com exceção da primeira coluna, "A Marmota", e do "Folhetim". O texto da primeira poderia assumir diversas funções, desde informativos da redação - em que se comunicava aos leitores alguma alteração no jornal, o início de um novo romance, a divulgação de uma promoção na tipografia etc. - até notícias recentes da cidade e do aparecimento de obras literárias. Como se sabe, folhetim era a seção literária de um jornal, que ocupava um espaço determinado, onde textos ficcionais (nacionais ou traduzidos) de leitura rápida eram publicados, por partes, e com a finalidade de entreter os leitores.

No cabeçalho da primeira página da Marmota, constavam o número da edição, o dia da semana e a data completa. Logo abaixo, vinha o nome do jornal, seguido por informações da tipografia e preço do exemplar, que variou de 80 réis (setembro de 1849) até 160 réis (dezembro de 1860) ${ }^{38}$.

Judas Político, O Marimbondo, O Pagode Catuca, O Pato Macho, O Pica-Pau, O Poraquê, O Sino dos Barbadinhos e O Testamento de Judas.

34. No século XVII, na Europa, o lanternista ambulante levava consigo a caixa para as projeções óticas e uma mascote, normalmente, um macaco ou uma marmota. Apesar de o animal, típico das regiões frias, nunca ter sido usado na corte brasileira, acabou emprestando seu nome ao brinquedo. Cf.: Laurent Manonni, A Grande Arte da Luz e da Sombra, p. 98.

35. A Marmota, n. 1.089 , p. 2, 9 set. 1859.

36. Hélio Vianna, Contribuição à História da Imprensa Brasileira, p. 273.

37. Há, no entanto, outros jornais que foram batizados seguindo, abertamente, o exemplo de Paula Brito. É o caso de A Marmota, na Bahia (1849); A Marmota Pernambucana, em Pernambuco (1850); e A Verdadeira Marmota do Dr. Prospero Diniz, novamente na Bahia (1852) fundados por Próspero Diniz, após sua partida da capital do Império. A afinidade de títulos, supõe-se, é devida à participação de seu fundador como redator no início de A Marmota na Corte.

38. Esse era o valor do exemplar avulso. Havia também o preço das assinaturas por período, que girava em torno de 3 mil réis para três meses para a corte, em 1860. Para se ter uma idéia do que representavam esses montantes, uma par 


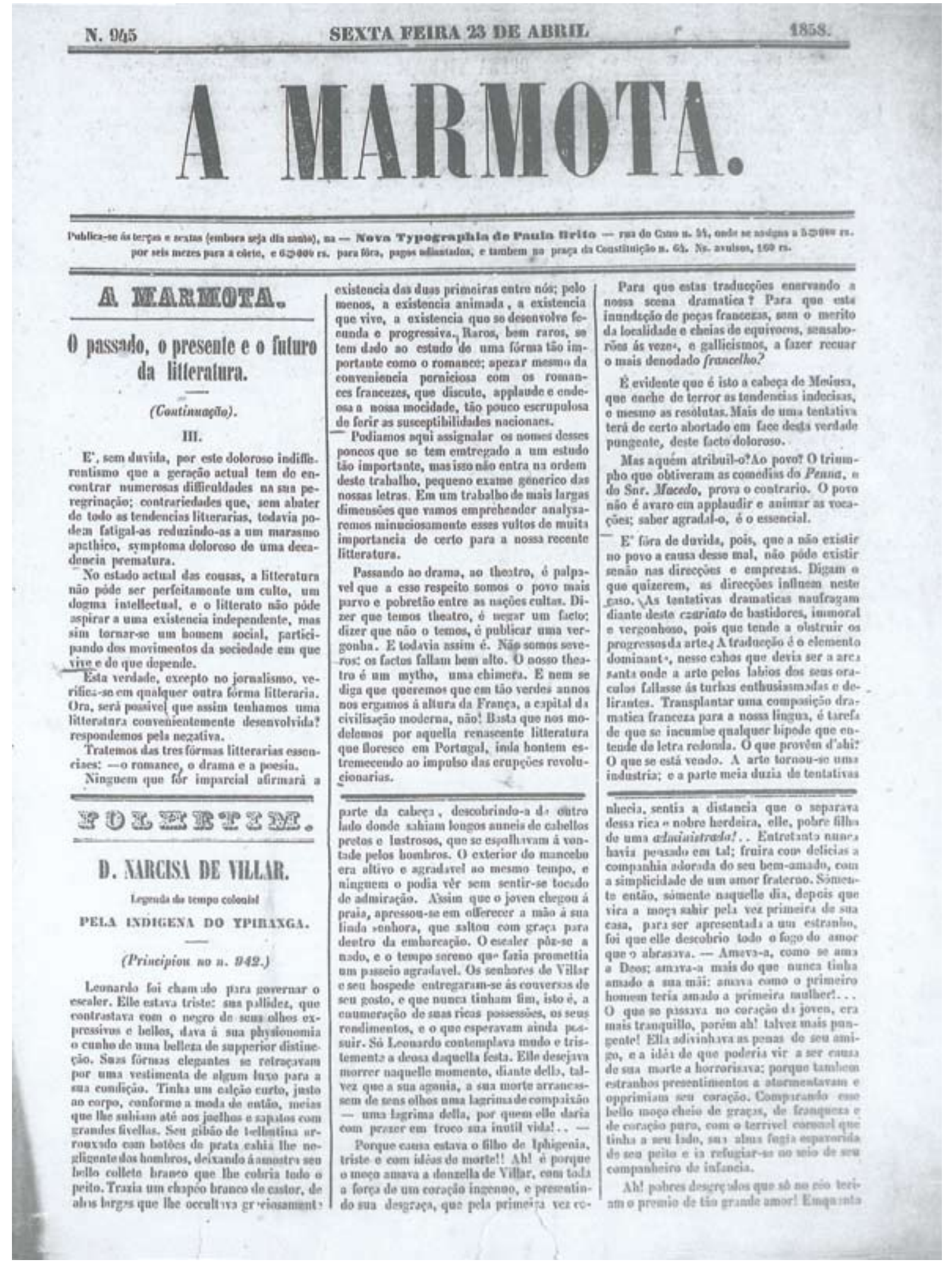

Figura 4. Reprodução da primeira página de A Marmota de 23 de abril de 1858. A coluna "A Marmota" traz o ensaio de Machado de Assis, "O Passado, o Presente e o Futuro da Literatura". O folhetim oferece aos leitores o romance D. Narcisa de Villar, de Ana Luísa de Azevedo e Castro (sob o pseudônimo de Indígena do lpiranga). 
A Marmota na Corte, para melhor caracterizá-la, no lugar de um subtítulo, trazia junto ao cabeçalho os seguintes versos:
Eis a MARMOTA
Bem variada,
Pra ser de todos
Sempre estimada.
Fala a verdade,
Diz o que sente,
Ama e respeita
A toda a gente.

Na fase de Marmota Fluminense havia um título subordinado: Jornal de Modas e Variedades, e até que sua apresentação gráfica fosse alterada pra três colunas, trazia sempre os dizeres:
Nas vistas desta MARmota
Há de ter sempre o leitor,
Com singeleza, e verdade
Tudo o que houver de melhor.

A Marmota, que circulou entre 1857 e 1861, trouxe o subtítulo Folha Popular em alguns números logo após a adoção do novo nome.

Sobre a disposição física dos textos, na página de abertura, havia a já mencionada coluna "A Marmota", com seu conteúdo variado. Além dela, eram divulgados nesse espaço esclarecimentos aos acionistas da Empresa Dous de Dezembro, algumas transcrições de correspondências destinadas a Paula Brito, notícias sobre a família real, comentários acerca de alguma data comemorativa nacional, novidades na corte, artigos sobre moda, textos religiosos e literários e até notícias de falecimento ${ }^{39}$. Dez colaborações de Machado de Assis tiveram espaço na primeira página do periódico, entre elas o soneto em homenagem ao aniversário de Pedro $\mathrm{II}^{40}$ e o ensaio de história e crítica literária "O Passado, o Presente e o Futuro da Literatura" ${ }^{41}$. A seção "Folhetim" também tinha início na porção inferior da página inicial, terminando normalmente na segunda; há casos em que se estende até a terceira ou em que nesta começa outro folhetim que irá até a última página.

A segunda página da Marmota mantinha praticamente a mesma linha da primeira, afinal,

de meias custava 1.800 réis e um par de sapatos masculinos cerca de 3.200 réis.

39. Os informes de óbitos podiam abranger desde personalidades conhecidas, como foi o caso de Casimiro de Abreu e do monsenhor Marinho, até pessoas sem renome, como dona Joaquina Rosa de Vasconcelos e Silva, amiga da mãe de Paula Brito. Cf.: A Marmota, n. 1.211, 9 nov. 1860; Marmota Fluminense, n. 561, 13 mar. 1855; Marmota Fluminense, n. 579, 4 maio 1855.

40. Marmota Fluminense, n. 654, p. 1, 2 dez. 1855.

41. A Marmota, n. 941, p. 1, 9 abr. 1858; e n. 945, p. 1, 23 abr. 1858. 
muitas vezes artigos iniciados na página um acabavam na dois. A terceira, geralmente, era destinada a versos: glosas de motes propostos, colaborações habituais, traduções ou mesmo uma nova divulgação de poemas conhecidos ${ }^{42}$. Também na página três era possível encontrar alguma música, como a "Ária da Negrinha-monstro"43 e o lundu "Ponto Final" ${ }^{44}$, ambos com letra de Paula Brito e música de J. J. Goyano.

Em certos números, no entanto, a terceira página trazia matérias de outro teor, como o artigo científico "Considerações sobre a Cólera-morbo" ${ }^{45}$. A doença assolou o Rio de Janeiro desde a década de 1830 até 1860 , quando começaram a ser instaladas as primeiras redes de esgoto na cidade, e atingiu principalmente as pessoas mais modestas e mal instaladas ${ }^{46}$.

A última página trazia igualmente alguns versos. Nela, foram publicadas, por exemplo, glosas mais humorísticas desenvolvidas pelos leitores:
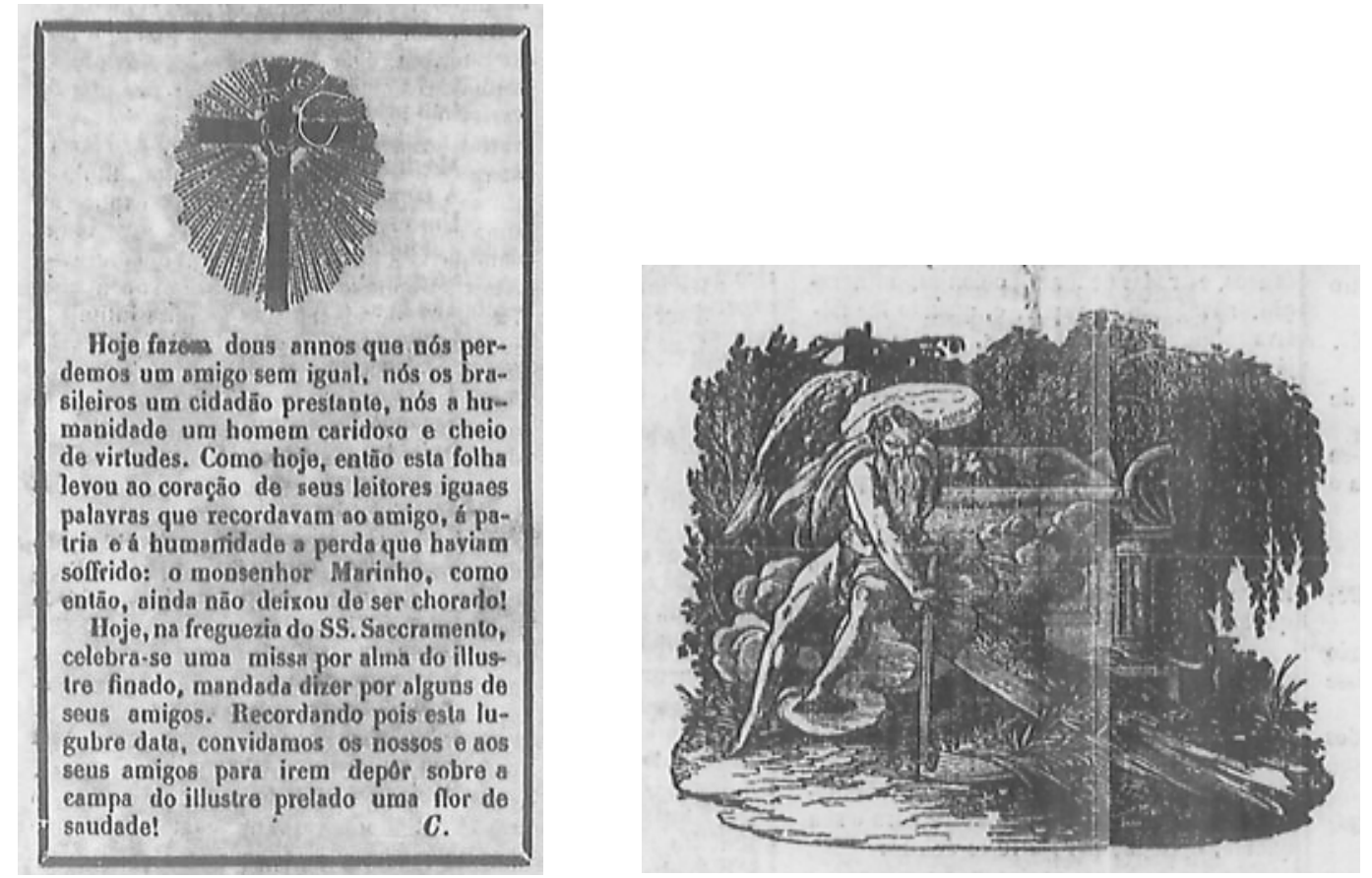

Figura 5. Imagens que adornavam os necrológios do monsenhor Marinho e de Joaquina Rosa de Vasconcelos.

42. Como O Uraguai, de José Basílio da Gama, cujo canto primeiro foi publicado na segunda página da Marmota Fluminense, n. 559, de 9 de março de 1855; ou Suspiros Poéticos e Saudades, de Gonçalves de Magalhães, cuja parte "Um Passeio às Tulherias" constava nas páginas 2 e 3 de A Marmota n. 903, de 2 de novembro de 1857.

43. Marmota na Corte, n. 136, pp. 3-4, 28 fev. 1851.

44. Marmota Fluminense, n. 383, pp. 3-4, 15 jul. 1853.

45. O artigo foi redigido pelo médico M. C. Pereira de Sá; cf. Marmota Fluminense, n. 654, p. 3, 2 dez. 1855.

46. Luiz Felipe Alencastro (org.), História da Vida Privada no Brasil, pp. 67-68 e pp. 78-79. 


\section{Mote}

Quem não gosta da Marmota,

Não sabe o que é cousa boa.

$$
\text { GLOsA }
$$

Quanto a mim, bela Carlota, Ente amado jamais foi.

Mísero é (Deus me perdoe), Quem não gosta da Marmota, Moço, ou moça, bem se nota A ser tal, que é muito à toa... Roa-se pois quem se roa... Querendo deus que ela ature, Todo o que a não ler não procure, Não sabe o que é cousa boa.

D. J. C. D. ${ }^{47}$

\section{Mote}

Eu pergunto ao Marmoteiro

Qual é mais inocentão;

Se o velhusco taberneiro,

Se o antiquário escrivão.

\section{GLOSA}

Pra firmar meu verdadeiro Juízo sobre um objeto Mui sério (sou circunspecto), Eu pergunto ao Marmoteiro: Se é fácil ao viageiro Encontrar um toleirão Na tarimba ou no balcão, Sela, convés ou boléia, $\mathrm{Ou}$, dentre tal patuléia, Qual é mais inocentão.

Qual mais probo, mais inteiro, Mais sincero ou mais simplório, Se o que vive no cartório, Se o velhusco taberneiro? Destes dous, ao derradeiro Dou a minha votação; Mas como sou patetão, Diga - Sr. Redator,

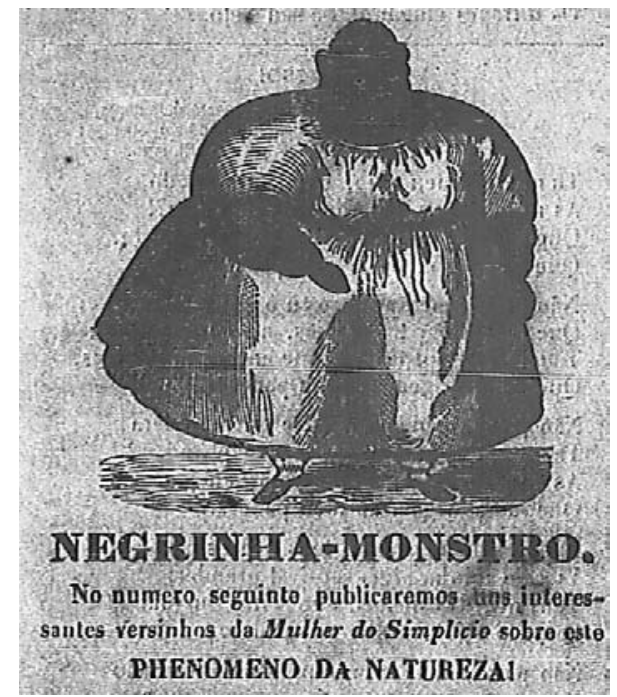

Figura 6. Vinheta anunciando a "Ária da Negrinha-monstro" em um próximo número da Marmota (21 jan. 1851).

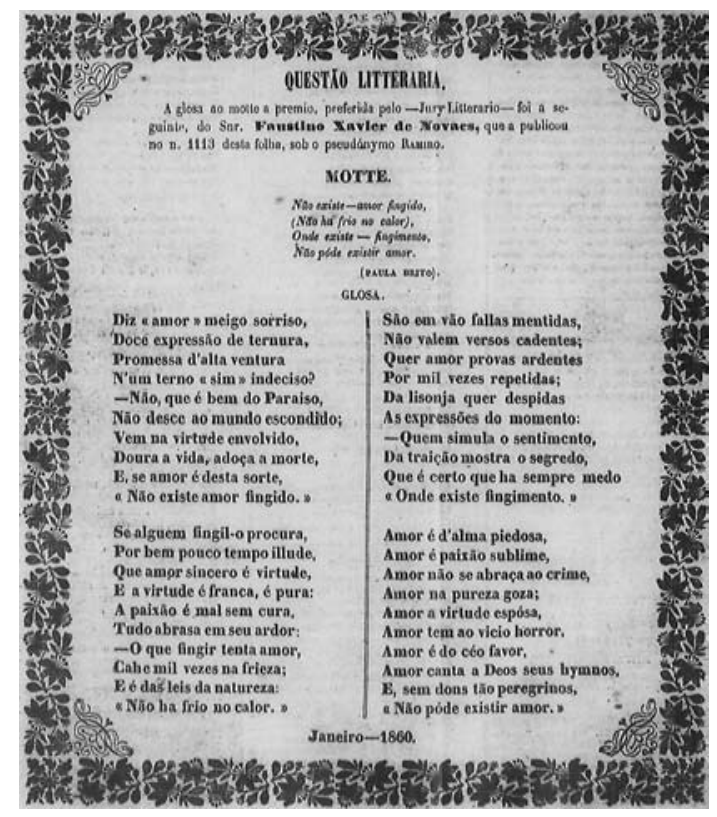

Figura 7. Glosa premiada de Faustino Xavier de Novais na primeira página da Marmota (6 jan. 1860). 
Se é do vinho o vendedor, Se o antiquário escrivão. $\mathrm{M}^{48}$

A quarta página era sempre recheada de entretenimento: apresentava máximas, charadas, logogrifos, anedotas, epigramas e metagramas e também fornecia as respostas dos desafios anteriores ${ }^{49}$. São transcritos aqui alguns exemplos dessas peças:

\section{Anedotas}

- Quando el-rei de Portugal, D. Pedro II, assinou a liga da Inglaterra contra Castela e França, perguntou por galantaria a um seu gracioso: - Que te parece esta liga? Senhor, respondeu ele: parece-me liga de tafetá podre com renda de tramóia.

$[\ldots]$

- Um médico inglês passeava com Hamilton, em um jardim, e espantava-se do crescimento que notava nas árvores. Não se admire, doutor, disse Hamilton, se elas não têm mais o que fazer ${ }^{50}$.

\section{Máximas e Pensamentos}

- O filho sábio é a alegria do seu pai; porém o filho insensato é a tristeza de sua mãe.

- A mulher diligente é a coroa de seu marido e a que pratica cousas indignas faz-lhe apodrecer os ossos.

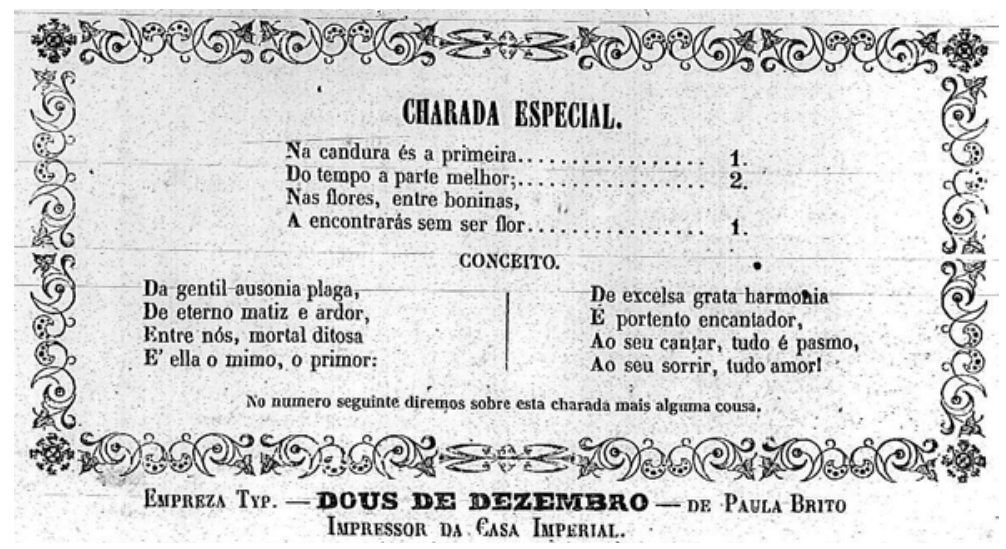

Figura 8. Charada especial (20 jul. 1852).

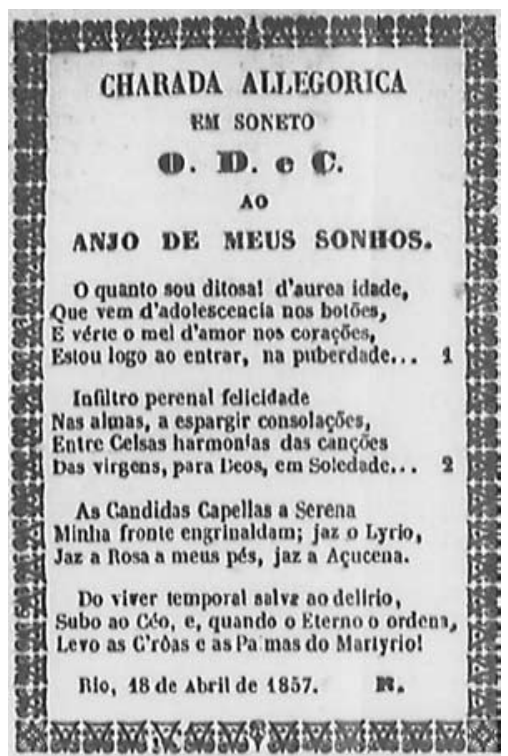

Figura 9. Charada alegórica na Marmota Fluminense (24 abr. 1857).

48. Marmota Fluminense, n. 383, p. 4, 15 jul. 1853.

49. Logogrifo é um tipo de charada que consiste em fazer diversas combinações com as letras de uma palavra insinuada pelo conceito, de modo que se chegue a uma série de palavras que é preciso adivinhar para se chegar à solução final. Epigrama é o dito espirituoso, breve e incisivo, que muitas vezes tem forma poética. Metagrama ou metaplasmo é designação comum a todas as figuras que acrescentam, suprimem, permutam ou transpõem fonemas nas palavras. Por exemplo: enamorar < namorar; cuidadoso < cuidoso.

50. Marmota Fluminense, n. 817, p. 4, 30 jan. 1857. 
- A mulher prudente edifica sua casa, e a ignorante destruirá ainda com suas mãos o que está já feito.

- Os pais dão casa e riquezas; porém, o Senhor dá propriamente uma mulher de prudência.

- Não dês teus bens às mulheres, nem empregues tuas riquezas em destruir os réis.

- O pudor tem por fundamento a temor das paixões ${ }^{51}$.

A página de fechamento era também o espaço destinado a anúncios dos mais variados segmentos: estabelecimentos comerciais, médicos, peças de teatro, outros periódicos, salões de cabeleireiros, colégios para moças, aulas particulares, modistas e alfaiates. Paula Brito aproveitava para anunciar seus produtos - obras editadas em sua tipografia, chá vendido em sua loja, cartões litografados e álbuns - além de vagas disponíveis nas suas oficinas.

Embora os anúncios estampados na Marmota fossem de teor bastante variado, não se encontrou na folha qualquer notícia sobre escravos fugidos ou assuntos de teor semelhante, como era habitual nos jornais de maior circulação na corte. Inclusive, são bastante escassas as alusões ao regime escravista ou a questões raciais no periódico de Paula Brito, como foi o caso da notícia "A Cólera", na qual falou-se que segundo "observação de pessoa entendida" - e confirmada pelo Visconde de Sapucaí - há sempre mais óbitos devidos à cólera nas segundas-feiras, quase sempre originários de "abusos e excessos praticados no domingo, sobretudo pela escravatura" ${ }^{52}$.

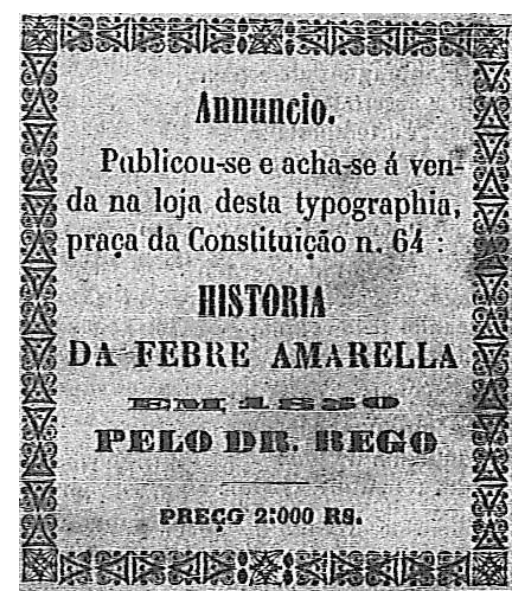

Figura 10. Anúncio da obra História da Febre Amarela do Dr. Rego, publicado na Marmota (1 abr. 1851).

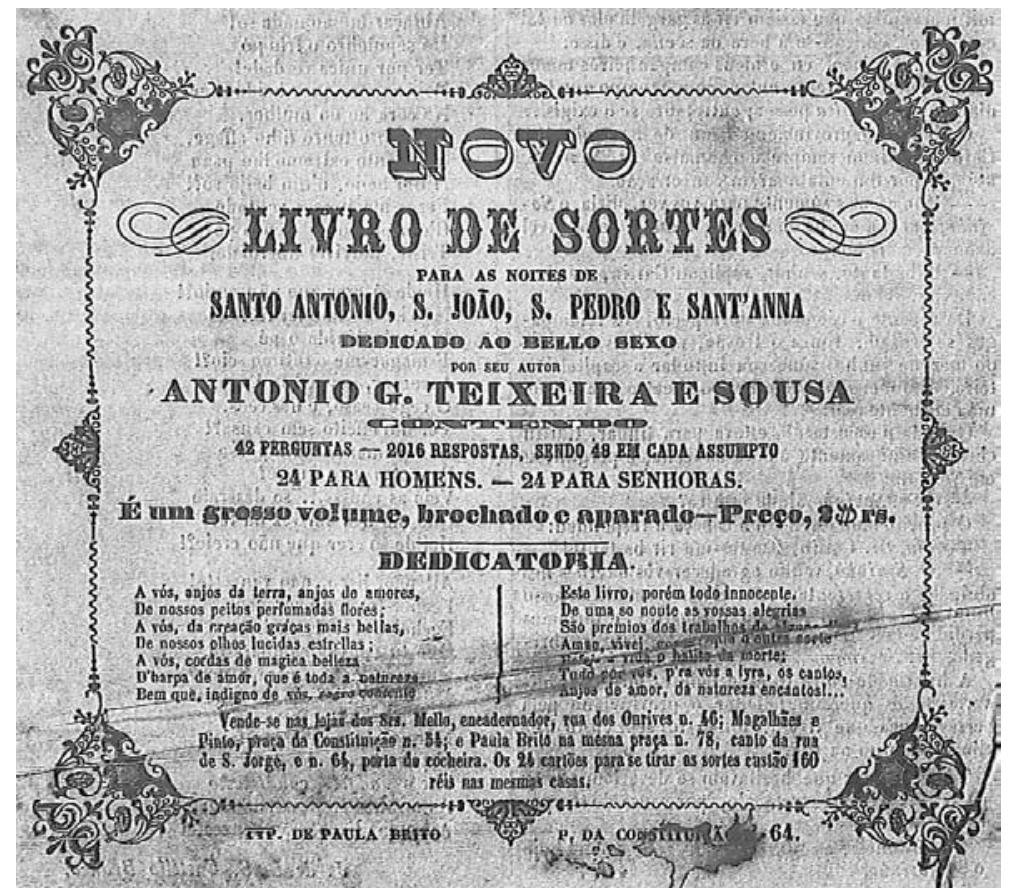

Figura 11. Anúncio do novo Livro de Sortes de Teixeira e Sousa na Marmota (30 maio 1851).

51. Marmota Fluminense, n. 539, p. 4, 12 jan. 1855.

52. Idem, n. 654, p. 3, 2 dez. 1855. 


\begin{abstract}
ANNUNCIOS.
Quo frescura! Que freseura

Ao eslor da ereatural..

Sorveles, das seis thoras en dianto, no botaquina da fama do - Cafte cour Leito - no largo do lloeio. Bans, baratus o perfeitns

Que spplacaun o caler do ardentes poitos:
E tomben ba limonades

Bean fresquinhas, o gollades

Do boem caja snboroso,

N. B.-Com dous tustoes unicamento muda indiriduo a stmesphera que reina dentro de loda a.marbins intestiet. irritando as viceras $\mathrm{com}$ as exalacóes caloricasl Passu-se repetitinamente de un verdo meridioaal para uma brisa fresca o consoladoral E tudo por dous tostoes, E mil vezes melhor do que un passeio do goedols; pois o sorreto toma-so desrançado, o no carro, leva-se tombos que fezem doer a cupula cerebral.

No mesino botequiin ba sala particular ondo podera as senhoras, ou familias, Lomarem o sorseto. ceoselido sein que o vulgo, que tranzito, observe
cousa alguan.
P. D. P. $D$.

REVISTA DO INSTITUTO HISTORICO.

Esta obra, que vai já no 13. - tomo, contée tudo quanto de mais importanto so tem eseripto sobre a bistnria do Brasil, e é procurada e conheçde na Europa, Acbam-se nuicamente a venda os voluinea que dolla ba aa loja de Paula Brito, propa de Cons-
títuiço a. 64, a 6 D rs. cada una. Nesta mesma cass recebersese tambem assigasturns pari' os numeros seguiates que, avulsos, venderẫo mais caros.
\end{abstract}

Figura 12. Propaganda do botequim Café com Leite - que serve inclusive sorvete em salas privativas para damas ou famílias e divulgação da Revista do Instituto Histórico e Geográfico Brasileiro, vendida somente na tipografia de Paula Brito (9 jan. 1852).

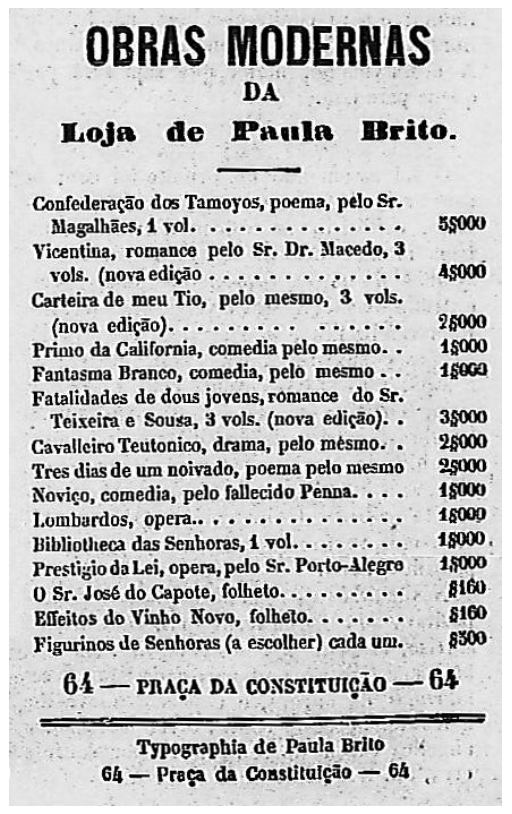

Figura 15. Anúncio de obras disponíveis na loja e Paula Brito (9 set. 1859).

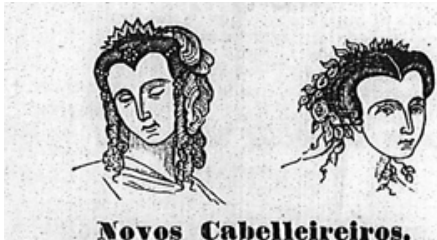

Novos Cabelleireiros.

Os Snrs. Baumeli, Donnat, e Charles, acabam de estabelecr na rua do Ouvidor n. 101, uma cas de perfumaria e de cortar cabello, denominada GABEÇA D'OURO.

Bastante conhecidos estes Snrs. nas casas dosSnrs. Desmarais e Silvain Jugan, onde exerciam sua profissão, podemos assegurar ao publico que elles possuem as habilitaçoès necessarias á arte do cabelleireiro. A - CABEÇA D'OURO - contém perfumarias de todas as qualidades, marrafas, cabelleiras, chinós, \&c., por todos os preços, e para todus os gostos. Fazemos votos para que a - CABECGA D'OUROseja bem acolhida do publico.

Figura 13. Anúncio de novos cabeleireiros na corte (5 maio 1852).

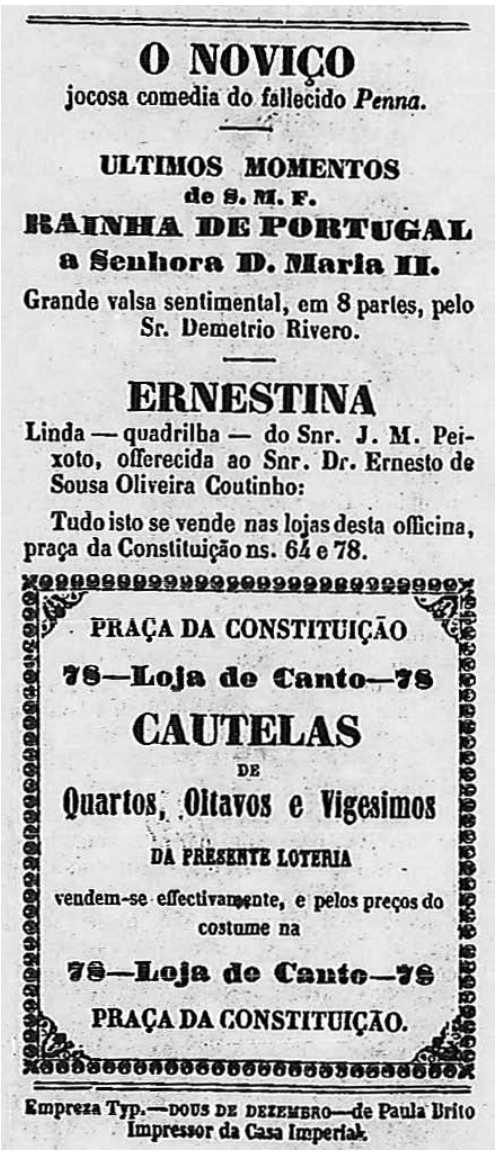

Figura 16. Propaganda de obras editadas pelas oficinas de Paula Brito, além de anúncio de venda de cartelas para loterias (3 fev. 1854).

\section{LODN DR PIPIL

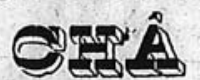 \\ OBJECTOS DE ESCRIPTORIO CHARUTOS}

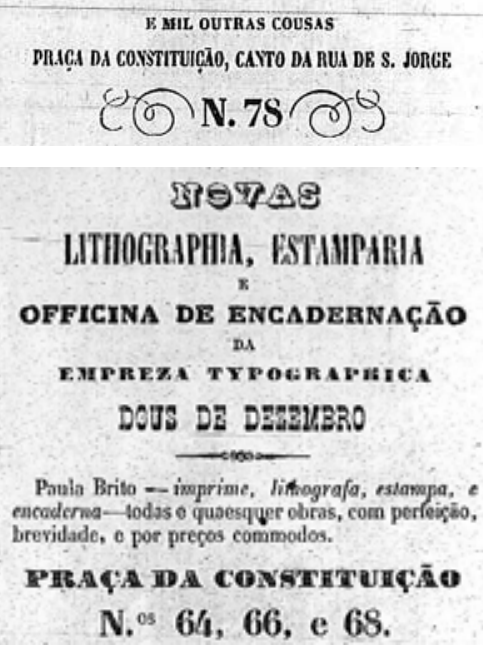

E MIL OUTRAS COUSAS PRAC̣ dA CONSTITUIC̣TO, CAYTO DA RUA DR S. JOREE (の) N.7S@

Iีค TAS

LITHOGRAPHIA, ВSTINPARIA

OFFICINA DE ENCADERNAÇ̄̄o is

EMPREA TYPOERAPUEA

DOJS DE DEZZUERO

Paula Brito - imprime, litagrafa, estampa, o encoderna - lodas o quaesquer obras, com perfeigiono, brevidade, o por precos commodos.

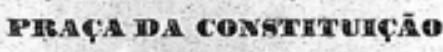

N. ${ }^{\text {os }} 64,66$, e 68.

Figura 14. Divulgação das lojas de Paula Brito (7 e 21 set. 1852).

Aulla dle 'Tachigraphilo ou Stenosmraplala.

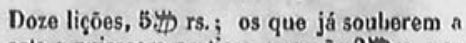
arle e quizerem praticar, pagnaño 3 WDrs. por mez. O professor fornece papel, tinta, \&zc., na rua das Mangueiras n. 17 .

N. B. - Lecciona-se igualmente em col. legios a em casas particulares.

\section{(1) GUANABARA}

pUbLICAdo SOB A rRotecgĩo

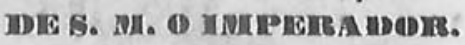

Publicnu-se o n. 12 do corrente mez de fevereiro, contendo:-

Problemu resolvido pelo Snr. Conselheiro Candido Baptista de Oliveira Meterologia - o Bombyx da mamonaEpisodio de um poema- o Ensaio Corographico dos Srs. Accioli e Mello-Moraes - Roma subterranea (impressóes de vingem) - o Sabio e o Justo - Secçio de Mineralogia e Geologia.

Com este n. terminou esta - lievista Scientlfica, Artistica e Litlereria - $02 .^{\circ}$ onno de sua publicaçâo.

Figura 17. Anúncio de aulas de taquigrafia seguido por publicidade da revista Guanabara (4 fev. 1855). 

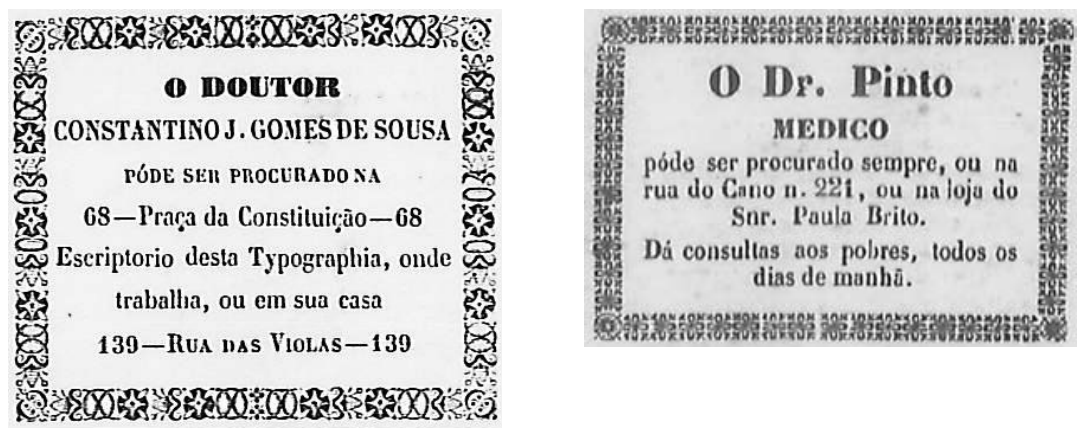

Figura 18. Anúncios de médicos na Marmota (17 out. 1854 e 3 set. 1861).

Outras exceções foram os artigos "A Malibran Preta", sobre uma cantora lírica negra, e a poesia "Simão - O Herói da Pernambucana”. Nesses versos, narra-se o trágico fim da embarcação Pernambucana, que havia deixado o Rio Grande do Sul em direção ao Rio de Janeiro com oitenta tripulantes. No decorrer da viagem, uma tempestade devastou o barco, muitas pessoas morreram, no entanto treze foram salvas pelo negro forro Simão, que era marinheiro. Os últimos versos da peça são:

\section{Ninguém a Simão despreze, Ninguém lhe negue louvor: SIMÃo fez atos divinos; A Virtude não tem $\operatorname{cor}^{53}$.}

Uma característica importante do periódico era a oferta de brindes aos seus assinantes, especialmente partituras e figurinos (que podiam ser impressos em cores). $\mathrm{Na}$ fase intitulada Marmota Fluminense, esses agrados eram sempre anunciados no cabeçalho do jornal. Quem não era assinante poderia adquirir as litografias e as músicas na própria tipografia.

Em 1859, o tipógrafo distribuiu aos assinantes da Marmota cartelas para concorrer a prêmios de até 200 mil réis, sendo que 150 mil réis seriam pagos em dinheiro e o restante em obras. Quem assinasse pela primeira vez ou renovasse sua assinatura por dois meses, pagaria 2 mil réis e receberia uma cartela com

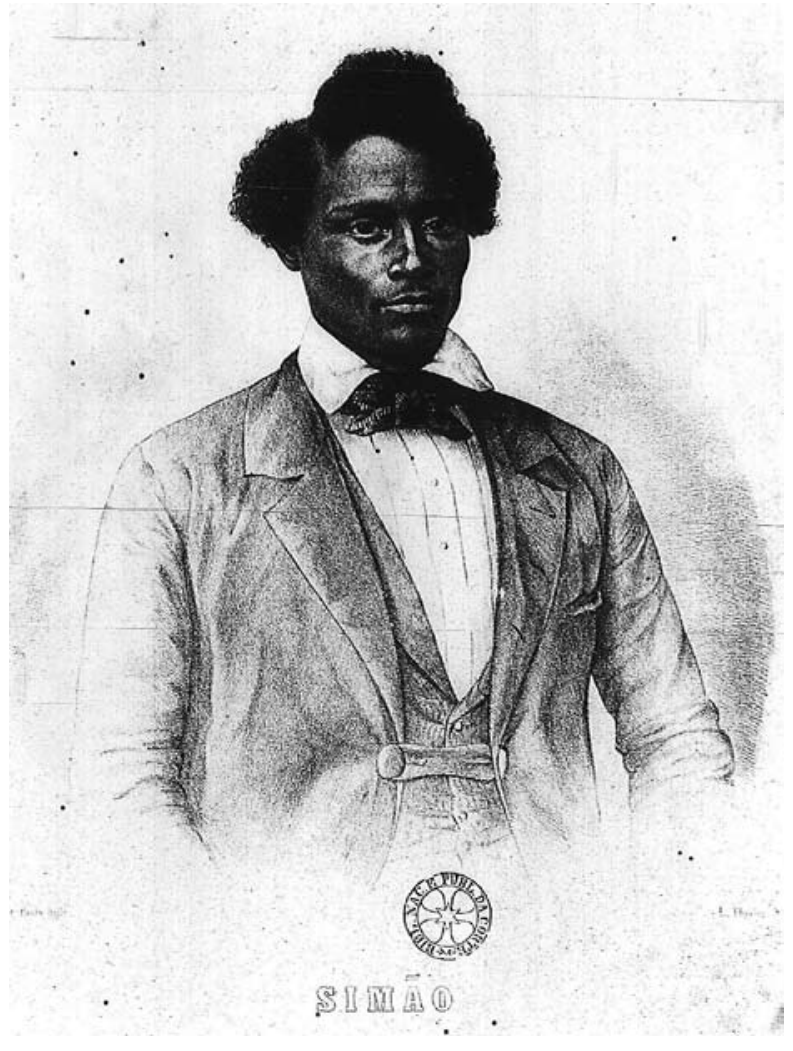

Figura 19. Retrato de Simão. 


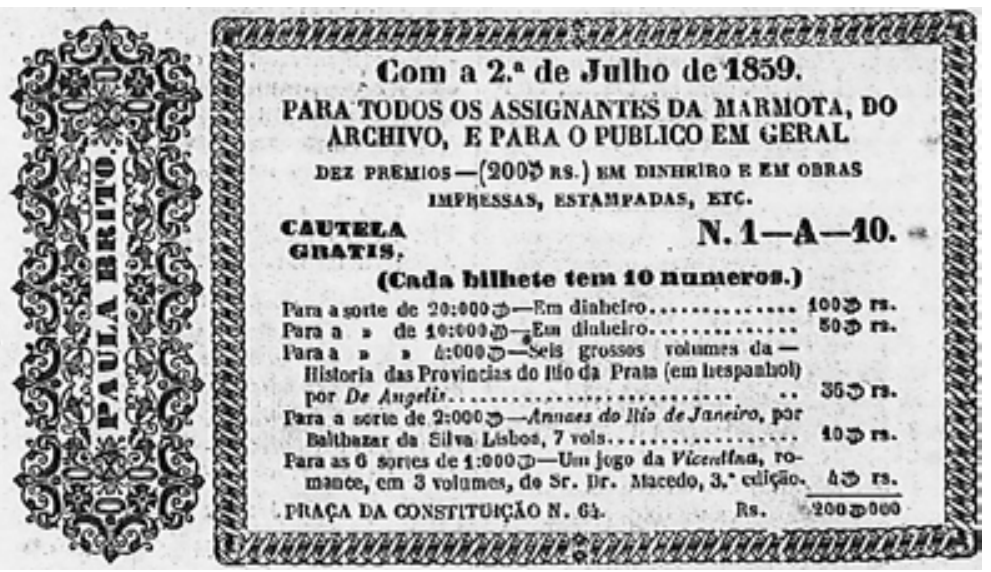

Figura 20. Exemplo de cartela com a qual os leitores da Marmota concorriam a prêmios.

dez números para disputar o prêmio. O mesmo valia para compras de livros nas lojas de Paula Brito ou assinatura da revista Arquivo Municipal.

Outra iniciativa interessante do tipógrafo foi publicar O Grátis da Marmota, que se assemelhava a um suplemento do jornal destinado apenas a propagandas. Todas as casas comerciais que quisessem ter seu anúncio publicado em $O$ Grátis, em 1859, deveriam pagar 100 réis por linha, sendo que se esperava maior adesão das lojas das ruas da Quitanda e do Ouvidor. Essa "especialidade", como chamou Paula Brito, era destinada tanto aos assinantes como ao "público em geral", distribuída gratuitamente. Encontrou-se um anúncio de O Grátis na Marmota em 1850: "O Grátis - aparece às quintas-feiras de todas as semanas, e distribui-se, como de costume, na corte e nas províncias. Recebe-se anúncios a 60 rs. por linha” ${ }^{54}$.

$\mathrm{Na}$ Marmota foram publicados alguns artigos da Sociedade Petalógica com o objetivo de levar a público os "trabalhos" realizados durante suas reuniões. No primeiro deles, explica-se o que é esse grupo:

A Sociedade Petalógica, ou de Petalogia, sociedade que, segundo o seu título, não trata senão de petas, é um ajuntamento de pessoas, mais ou menos instruídas, que há cerca de 20 anos se reúnem num dos lugares mais belos e mais conhecidos dessa Corte. Criada espontaneamente sem nome, ao princípio o seu fim era todo político; mas como mudam-se os tempos e nós mudamos com eles - tempora mutantur, nos et mutamur in illis -, passou a ser unicamente recreativa, podendo todo o mundo que nela tem assento expender com franqueza a sua opinião, com tanto que haja de responder pelos abusos que cometer no exercício desse direito. Exceto vida particular de famílias, de tudo se trata na Sociedade Petalógica ${ }^{55}$

Como mencionado, a sociedade não tinha esse nome, no entanto os sócios decidiram adotálo "para ensinar a mentir aos que passavam por dizedores da verdade", ou seja, a idéia era satirizar os reconhecidos mentirosos criando histórias mais inverossímeis que as deles próprios. 
Figura 21. Figurino distribuído com a

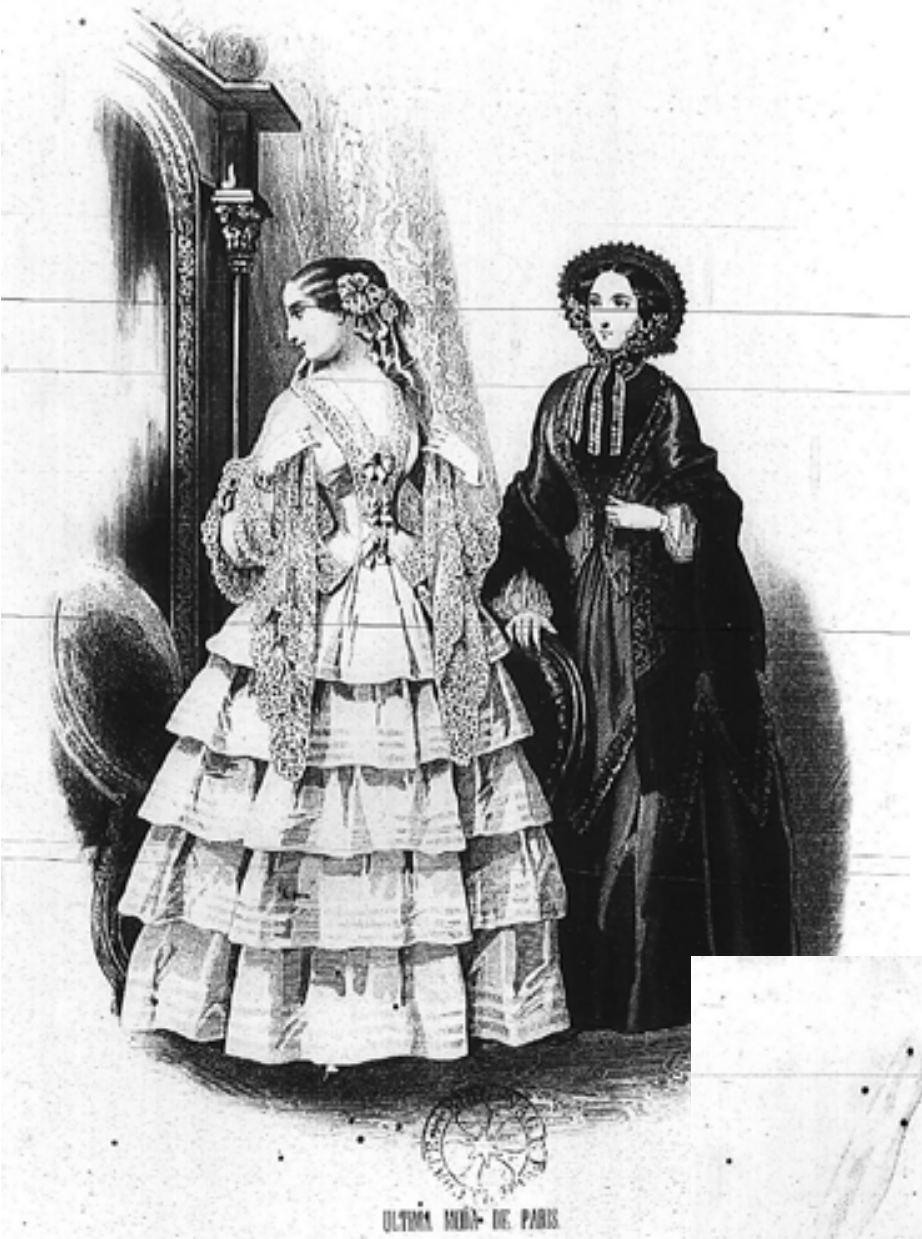

Marmota (2 fev. 1853).

Figura 22. Figurino distribuído com a Marmota a seus assinantes (17 fev. 1852).

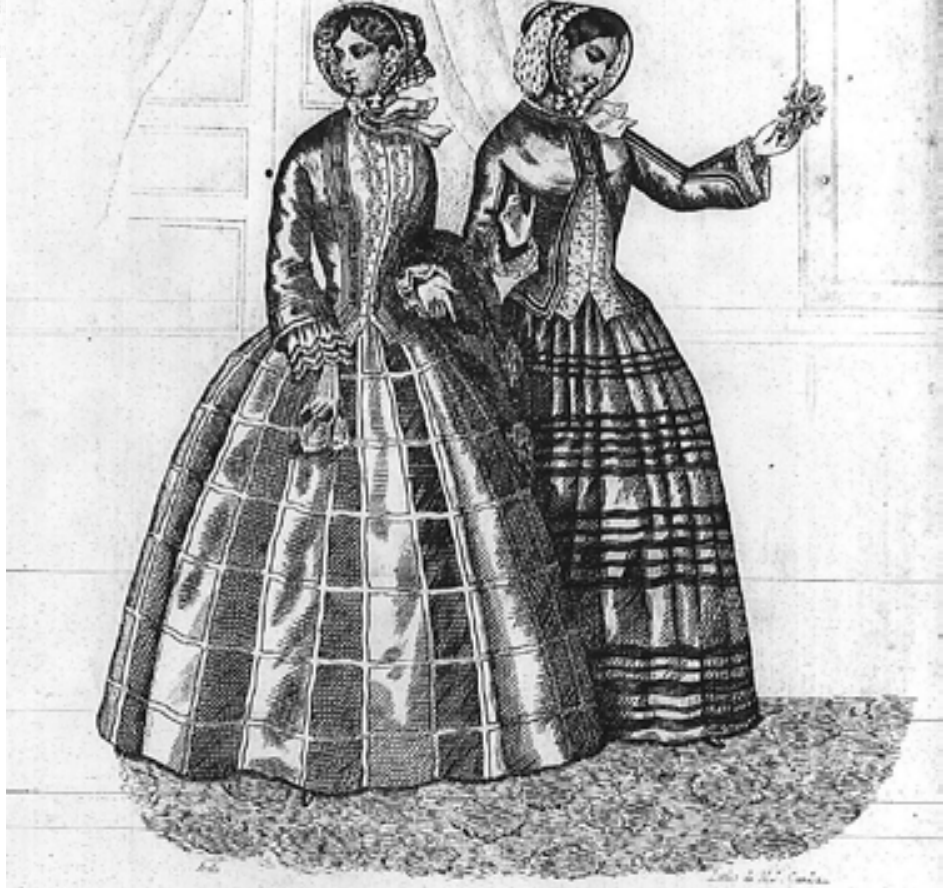

MARMOTAGE NA CORTE. N:236 


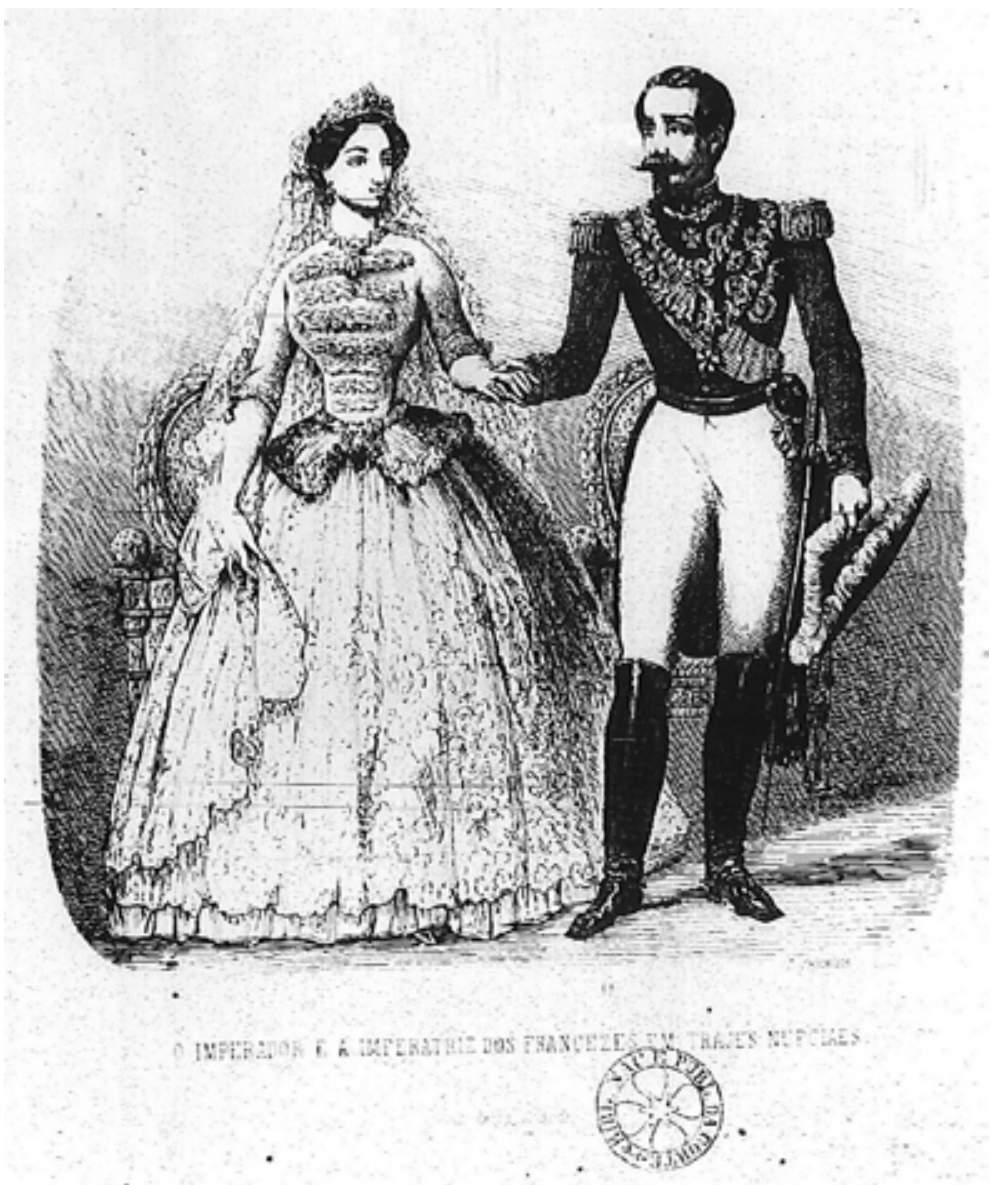

Figura 23. Gravura do casal real francês em trajes matrimoniais.

Figura 24. Figurino litografado.

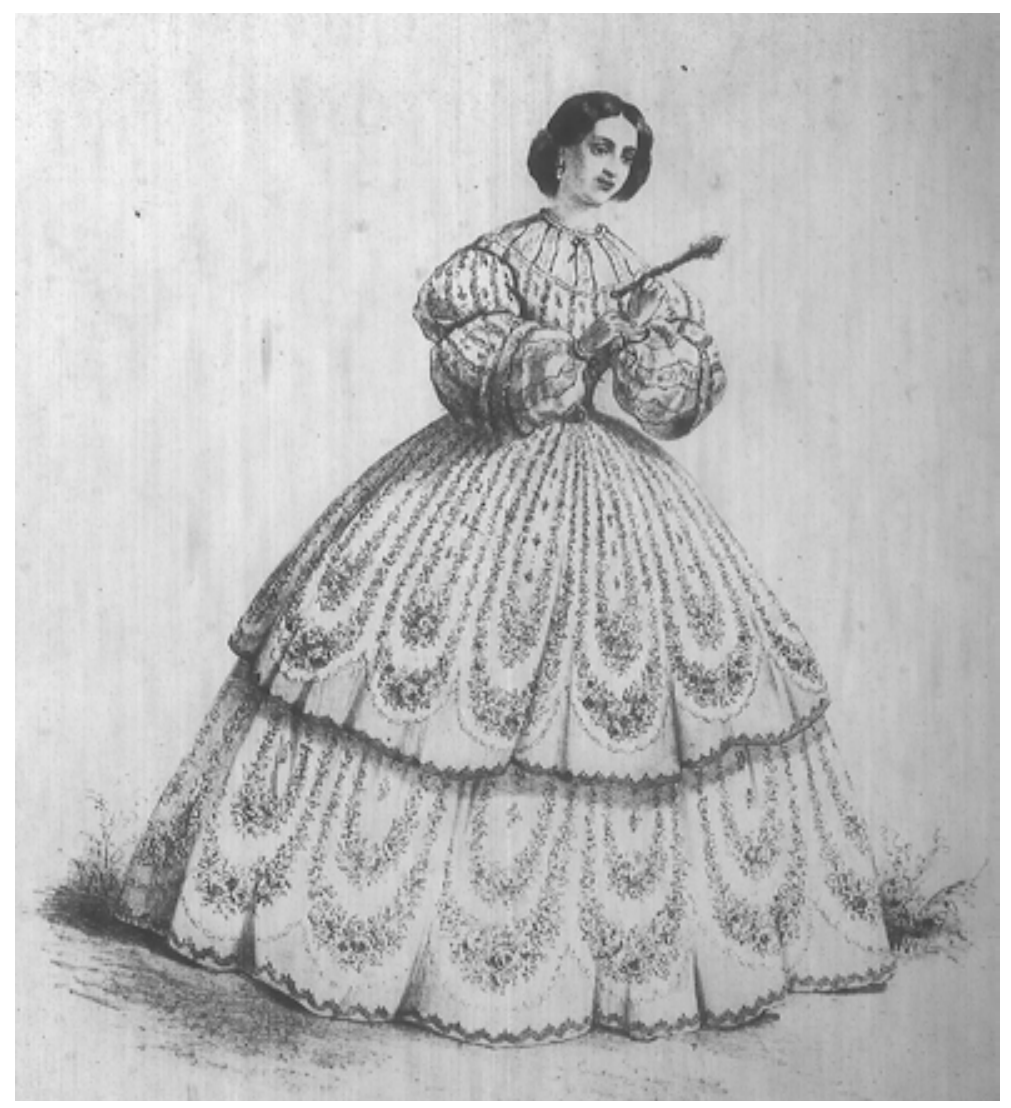


Os textos publicados na Marmota eram "relatórios" dos discursos proferidos nas sessões da associação. Em uma delas, um dos sócios pediu a palavra para contar uma história que "viu" e "ouviu". Chegando um carregamento de chouriços de ótima qualidade na cidade, uma dos barris que levava a carga abriu-se e um chouriço caiu na rua, justamente próximo ao local onde estrangeiros soldavam um cano de gás. Com o cheiro que o chouriço meio tostado exalou, logo apareceram ingleses desejando disputá-lo com os outros estrangeiros, o que se tornou uma questão diplomática. Está armada a confusão na rua, piorada pela presença de uma carroça carregada de vinho, de caixeiros e de um cão que escapou com o petisco e foi degustá-lo em uma ilha próxima ${ }^{56}$. Essa lorota gerou inspiração, pois logo a Marmota publicou os versos "O Horror que Causa um Chouriço" juntamente com a uma caricatura $^{57}$.

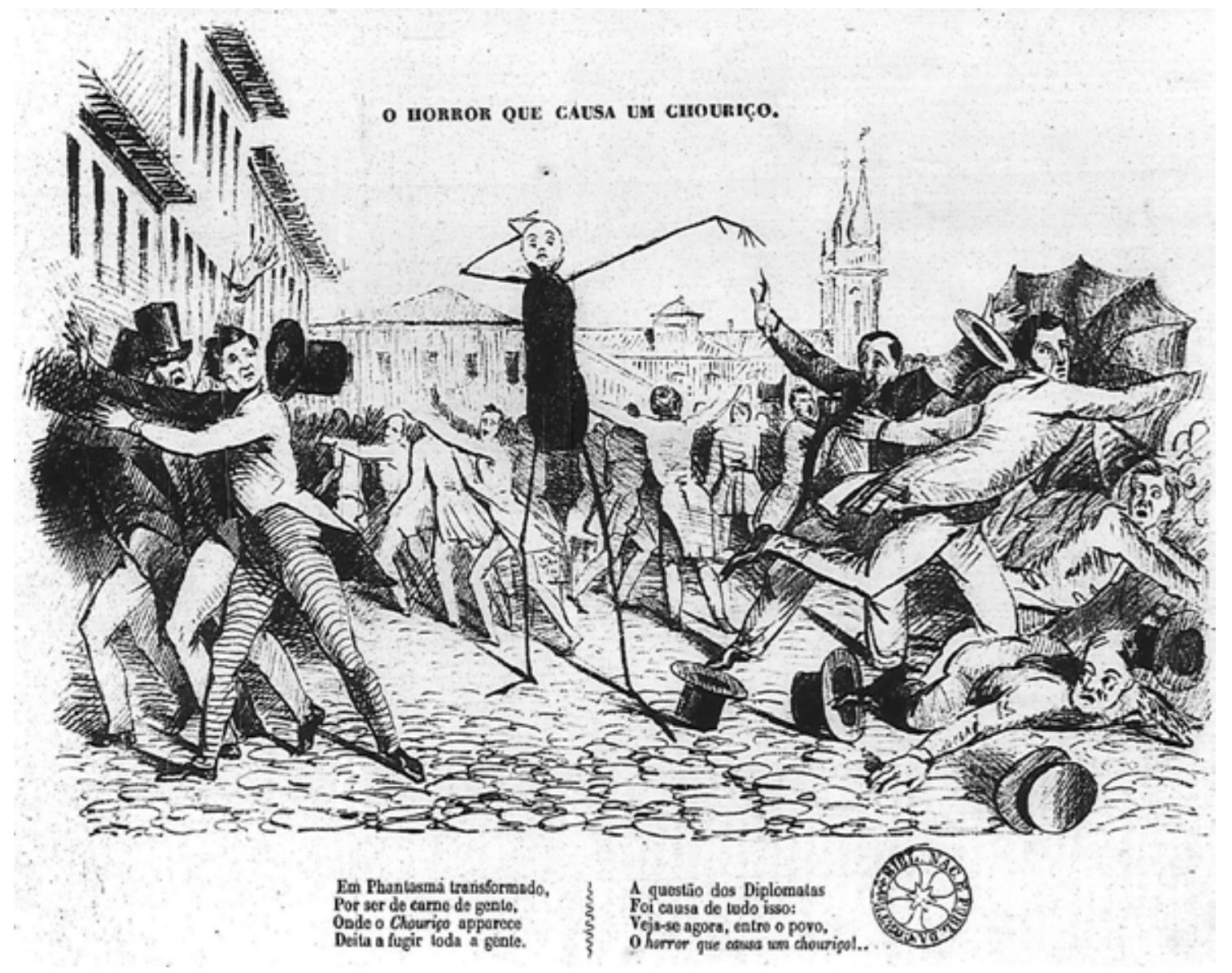

Figura 25. Caricatura "O Horror Que Causa um Chouriço" na Marmota (16 set. 1853).

56. Marmota Fluminense, n. 390, p. 1, 9 ago. 1853.

57. Idem, n. 391, 16 ago. 1853. 
Retomando brevemente a criação da Empresa Tipográfica Dous de Dezembro, antes de concretizá-la, Francisco de Paula Brito publicou interessantes artigos sobre a conveniência da tipografia para o país, que revelam o desenvolvimento das artes gráficas e até mesmo da imprensa no período.

Em maio de 1855, o proprietário da Marmota divulgou os "Estatutos da Nova Empresa Literária Dous de Dezembro", que já haviam sido submetidos à aprovação do governo e que aguardavam resposta, em cujo artigo quinto lia-se: "A diretoria por si, conjuntamente com o administrador Francisco de Paula Brito, ou este por si só, requererão aos poderes do Estado o auxílio que se julgar conveniente, dando-se pra isso todas as razões precisas" ${ }^{\prime 5}$. Desse modo, estava evidente que além da autorização para funcionamento de uma sociedade por ações, Paula Brito também iria necessitar de suporte financeiro governamental.

Logo após os estatutos estava estampada a matéria "A Vantagem das Tipografias", assinado por Paula Brito. Neste texto, seu autor informa que foi com surpresa que recebeu a notícia de que o Jornal do Commercio publicou uma matéria que apoiava sua idéia de que a impressão em larga escala impulsionava o desenvolvimento do país. Para ilustrar sua afirmação, o jornal divulgou alguns dados sobre periódicos ingleses, notadamente o The Times. Esta folha sozinha, em 1854, teve 15.975.739 exemplares impressos e anualmente pagava cerca de 95.000 libras esterlinas, o equivalente a 845 contos de réis, em impostos sobre selo e papel ao Estado. Ou seja, uma pequena fortuna, levandose em consideração que em 1825, após a Independência brasileira, Portugal havia elaborado uma carta exigindo o pagamento de todos os bens portugueses que tinham permanecido na ex-colônia, incluindo a Real Biblioteca, cujo valor havia sido estimado em 800 contos de réis ${ }^{59}$.

Em outro artigo defendendo a causa das tipografias, cujo objetivo particular era criar uma propaganda favorável à Empresa Tipográfica Dous de Dezembro junto ao governo, Paula Brito descreveu com pormenores os gastos diários de um prelo de ferro com papel, tipos e tinta e calculou que os impostos pagos por dia ao Estado chegavam a 2.700 réis. Segundo sua exposição, a Empresa Dous de Dezembro tinha em funcionamento dez prelos para impressão tipográfica e cinco prelos de ferro para a litografia; oferecia os serviços de encadernação e estamparia, e ainda arcava com a remessa para fora da corte dos periódicos Marmota, Guanabara e Anais de Medicina. Em vista de tudo isso, ele argumentou:

Demonstrado, pois, como fica a toda evidência é que a - Empresa Dous de Dezembro - é, só nesta parte, de nítida utilidade para o país, pelo que diz respeito a dinheiro, porque paga anualmente de 10 a 12 contos de réis; de menor utilidade não é ela, tendo em efetivo trabalho 60 empregados, sendo estes: -9 franceses, 5 portugueses e 46 brasileiros.

Não há grande nau sem grande tormenta. O que pede o empresário, para poder incorporar uma nova companhia ou associação, é nada para o que pode fazer o governo. $[\ldots]$

58. Idem, n. 583, pp. 1-2, 18 maio 1855.

59. Jurandir Malerba, A Independência Brasileira, pp. 288-289. 
Tendo já feito muito pelo seu país, só e sem recursos, é esta a primeira vez Paula Brito recorre aos Poderes do Estado, para fazer de uma vez o que de certo se não fará, a não ser pelo meio proposto ${ }^{60}$.

Sobre a transformação da tipografia de artesanato em indústria, segundo Wilson Martins, as principais etapas que marcam esse processo são: a invenção da máquina de papel em 1789, a criação da prensa mecânica em 1812, o desenvolvimento da prensa rotativa em 1850 e o linotipo, em 1885. A prensa mecânica, por sua vez, teve dois momentos distintos em sua evolução, de 1445 a 1814 ela dependia de força muscular para funcionar; depois desse intervalo, ela passou a ser movida a força motriz, inicialmente o vapor ${ }^{61}$.

Enquanto a tipografia tardou séculos para ser instalada no Brasil, a litografia chegou ao país logo após sua introdução definitiva em países europeus, como França. É um processo de gravura artesanal que consiste na reprodução impressa de um desenho traçado com material gorduroso sobre uma pedra calcária.

A oficina litográfica de Paual Brito foi inaugurada em 1852, fazendo parte da Empresa Tipográfica Dous de Dezembro. O tipógrafo trouxe de Paris o litógrafo Louis Thérier que começou a produzir trabalhos em preto e branco para depois iniciar as cromolitografias. Além das imagens estampadas na Marmota, especialmente os figurinos, a oficina litográfica de Paula Brito produzia matérias para outros periódicos, como o Brasil Ilustrado ${ }^{62}$.

Moreira de Azevedo, organizador do volume das poesias póstumas de Francisco de Paula Brito, tece um breve comentário sobre a Marmota e a posição que a revista ocupava em seu tempo:

Todos sabem o que foi a Marmota. Se não era um jornal de boa literatura, era agradável e variado.

Os serviços que esse periódico prestou às letras, à mocidade, todos também sabem: jamais em jornal algum nosso se encontraram tantos artigos de moços, de talentos nascentes. Durante doze anos de vida nunca apareceu nesse periódico uma palavra acre, uma injúria contra alguém, o que se encontra aí em cada pagina é animação, é elogio ao verdadeiro talento ${ }^{63}$.

As palavras "todos sabem" podem ser entendidas como índice da popularidade do jornal, mas é mais provável que se restrinjam ao universo exclusivo dos leitores da folha. De qualquer forma, não deixa de ser argumento em favor da construção da imagem de Paula Brito, que então começa a se constituir em discurso histórico-cultural.

60. Marmota Fluminense, n. 584, p. 1, 22 maio 1855.

61. Wilson Martins, A Palavra Escrita, pp. 236-237.

62. Orlando da Costa Ferreira, op. cit., pp. 390-391.

63. Manuel Duarte Moreira de Azevedo, "Biografia”, em Francisco de Paula Brito, Poesias de Francisco de Paula Brito, p. XXII. 

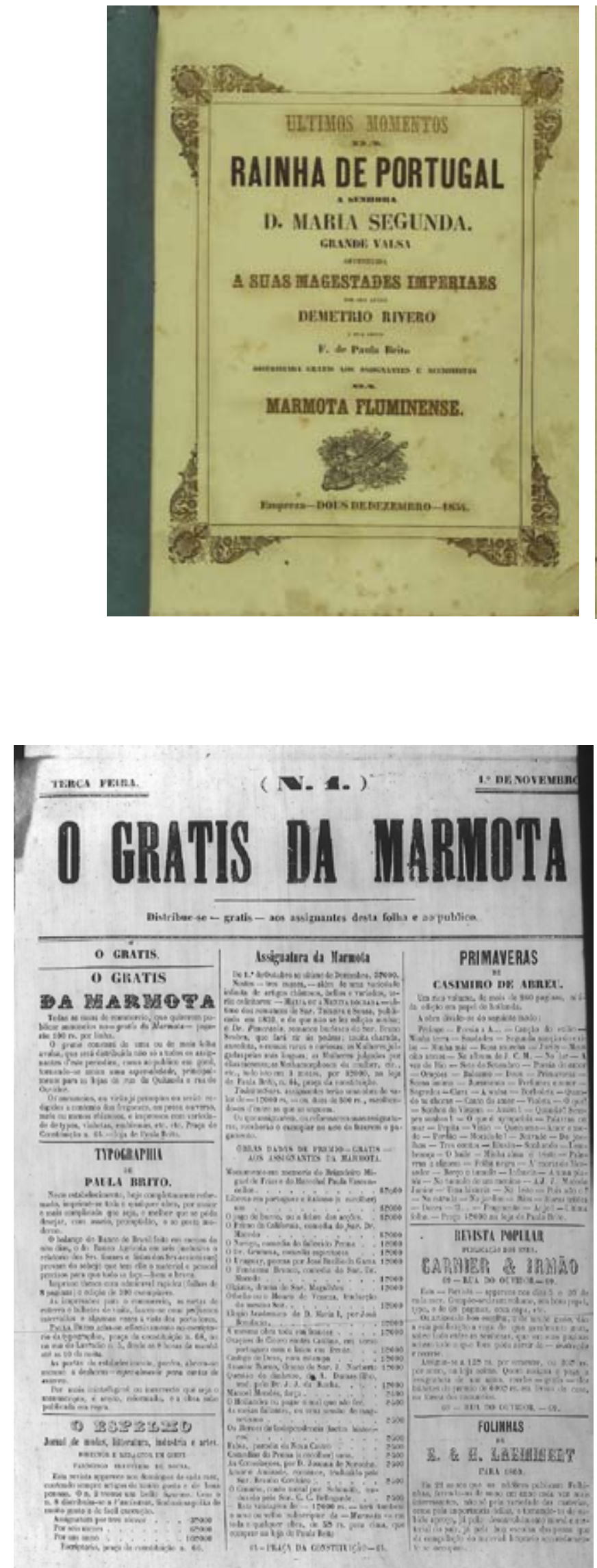

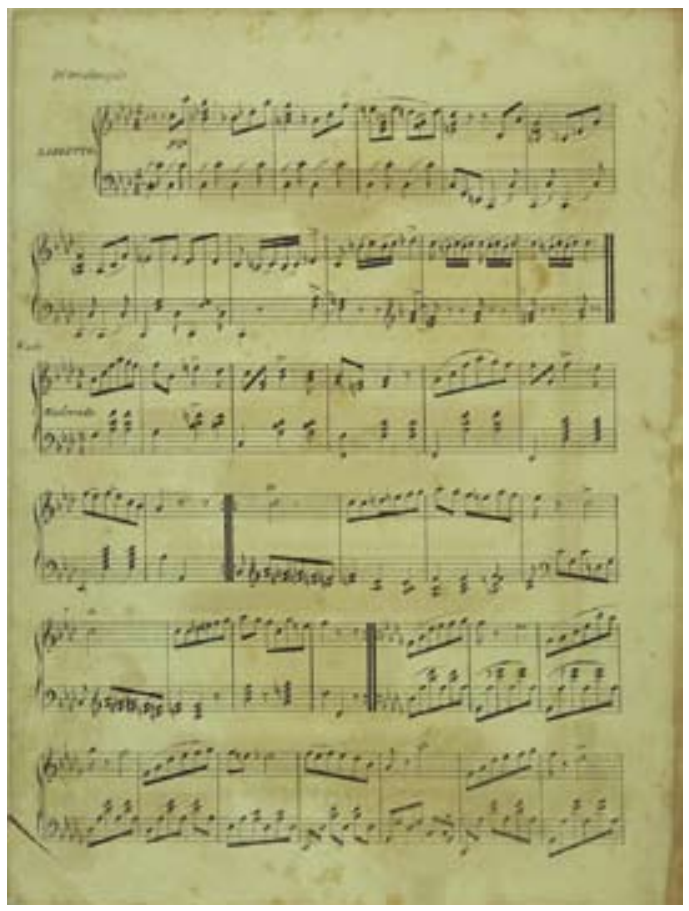

Figura 26. A valsa Últimos Momentos da Rainha de Portugal, a Senhora D. Maria Segunda, de Demétrio Rivero, foi um presente aos assinantes da Marmota em 1854.
Figura 27. O Grátis da Marmota com anúncios de casas comerciais (1 nov. 1859). 


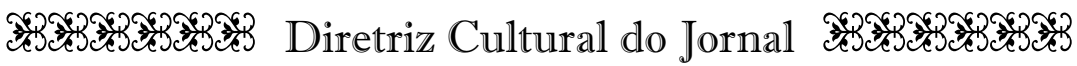

No primeiro número do periódico datado - não por acaso - de 7 de setembro de $1849^{64}$, há indícios da linha editorial que a publicação pretende seguir, como se percebe no texto assinado por Próspero Diniz:

E para que escreve ele [o redator] esta folha, será por interesse? Não que isso é uma paixão tão feia, que hoje em dia ninguém a quer seguir; ele escreve só para servir a pátria d’algibeira, que assim o exige o brio e denodo de um cidadão liberal [...].

Esta folha há de ser um guizadinho saboroso, e bem temperado por tal forma que faça os leitores ou convidados dela lamberem os beiços e pedirem repetição da dose: há de ser um pudim de cousas boas; há de levar o leite da verdade, o pão da religião, os ovos das pilhérias, o cidrão da lei, as passas da poesia, a noz-moscada da crítica, e por fim a canela da decência para aromatizar o paladar das famílias, e dar uma vista agradável ao bolo. Ora pois, abram a boca e fechem os olhos para chuparem o petisco.

[...] rogo à bela rapaziada desta cidade (que bastante viveza tem), que me remetam à tipografia notícias interessantes que eu publicarei, e basta só darem o tema que eu farei o sermão. Os que tiverem veia poética mandem todas as poesias que fizerem, ainda mesmo incorretas que eu as corrigirei, e quanto à crítica suprirei a falta, ainda que mal, do extinto $Z$, o qual tanto apreço teve por analisador. Rapazes, patuscos, estudantes, caixeiros, todos, todos, cheguem para mim, ajudem-me com as informações da terra que verão como o negócio toma caminho, crescite et multiplicameni.

O nosso plano é reformar abusos recrear os leitores, e ganhar a estimação das simpáticas meninas que honrarem a Marmota com as suas mãozinhas macias [...].

Apresentaremos também em nossa folha máximas muito apreciáveis, que ainda não foram publicadas, charadas, logogrifos, receitas curiosas etc. etc ${ }^{65}$.

Parodiando uma receita culinária, fala-se nas seguintes "cousas boas": verdade, religião, pilhérias, lei, poesia, crítica, decência e famílias. Portanto, muito além de um jornal de variedades e entretenimento, a Marmota traz a seu público elementos moralizantes e formadores, reforçando, por meio deles, o ideário do Segundo Reinado - catolicismo, obediência às leis do Estado monárquico e formação da família burguesa.

Como expresso nesse editorial, o plano para o jornal é "reformar abusos e recrear os leitores", ou seja, educar pelo entretenimento. Não se trata de modo algum de uma iniciativa original, ao contrário, essa premissa foi exposta por Horácio em sua Arte Poética.

64. A data de aniversário da Independência do Brasil, escolhida por Paula Brito para o lançamento do jornal, reflete suas preocupações nacionalistas.

65. A Marmota na Corte, n. 1, pp. 1-2, 7 set. 1849. 


\section{FunÇão DA Poesia \\ XXXI}

Ou causar instrução ou dar deleite

Ou unir cousas úteis a jucundas

O poeta pretende. Se instruirdes,

A brevidade amai, para que possa

Perceber-se e reter-se o que ensinardes:

Tudo o que é demasia são sobejos

Perdidos de um juízo que está cheio.

Se divertir quiserdes, verossímeis

Sejam vossas ficções: e cuidai muito

Em não fiar na cena quanto pede

O cômico Argumento; como vermos

Tirar do ventre de uma feiticeira

Vivo um menino que antes devorara.

O Corpo Senatório não aprova

Assuntos que não sejam proveitosos;

O dos nobres não gosta dos austeros:

Quem sabe, pois, tecer ação que instrua

E juntamente agrade, esse é que leva

$O$ voto universal; esses Poemas

Enriquecem livreiros, passam mares

E dão ao seu autor imortal nome ${ }^{66}$.

No trecho aqui intitulado "Função da Poesia", Horácio afirma que para instruir não se pode ser exaustivo e que para divertir há que se ter verossimilhança, logo, a ação mais eficaz envolve o equilíbrio, ensinar sendo agradável. Esse era, sem dúvida, também o propósito da Marmota.

No editorial do primeiro exemplar revela-se, também, qual o público que o jornal pretende atingir: "Rapazes, patuscos, estudantes, caixeiros" e "simpáticas meninas". Não se buscava, portanto, os leitores da grande imprensa do período, os "homens sisudos", a quem interessavam os textos políticos e noticiosos. Pretendendo atuar na formação cultural e moral, a Marmota era voltada principalmente para os jovens estudantes que se dedicavam a ler e compor versos e ao público feminino.

Por essa mesma época, a formação moral era também o objetivo dos manuais de civilidade que, vindos de Lisboa ou diretamente de Paris, chegavam ao Rio de Janeiro. A partir da chegada da família real ao Brasil, a necessidade de convívio social (em bailes, teatros, igrejas ou cerimônias oficiais), impôs uma reformulação geral nos costumes coloniais, obrigando a "boa sociedade" a "civilizar-se".

Após a Independência, esses manuais de etiqueta e civilidade juntamente com jornais destinados ao público feminino - como era o caso da Marmota - foram os principais veículos de difusão de bons costumes e cortesia condizentes com as novas formas de relacionamento que se 
instauravam na corte carioca. Essas publicações se preocupavam em difundir ensinamentos relativos a comportamento social, higiene do corpo, cuidado com as vestimentas, trato com pessoas e, também, respeito à hierarquia social.

Sabe-se que enquanto os manuais de civilidade cumpriam o papel de ensinar um conjunto de regras necessárias para o bom desempenho da vida social baseadas, fundamentalmente, na aparência e nas formas de apresentação pessoal, os jornais buscavam principalmente suprir falhas na formação e instrução de seus leitores ${ }^{67}$.

Nesse sentido, ordem, etiqueta, cortesia, civilidade e política pareciam se articular para garantir o equilíbrio social e podem ser entendidas como parte de um mesmo processo de construção de imagem da nova nação.

A tentativa de moldar a sociedade, o desejo de impor um padrão da civilidade e a necessidade de reformar a tradição de uma sociedade fundada sobre o colonialismo geraram a demanda por uma referência civilizatória que funcionasse como modelo dos novos costumes e comportamentos. Vindos da Europa, esses valores morais e modos de comportamento se disseminaram pelo mundo.

Paula Brito em diversas oportunidades declarou os objetivos que pretendia alcançar com sua folha. Embora ele próprio muitas vezes tenha registrado simplesmente que se tratava de um jornal para divertimento, como mencionado anteriormente, o princípio subjacente era moralizar, especialmente por meio do entretenimento. A seguir transcreve-se algumas quadras de sua poesia "Eu, e as Minhas Lembranças":

\author{
É nesta vida a Mulher \\ Um - Anjo - sempre pra mim; \\ Assim meus Pais me educaram; \\ Meus filhos educo assim. \\ Vamos, porém, ao que serve, \\ Que o meu fim é divertir \\ Aos que lerem a Marmota \\ Nela achando de que rir. \\ Há Científicas folhas, \\ Há folhas Comerciais, \\ Há de Política muitas, \\ Enfim, de tudo há jornais! \\ Da Marmota eu fazer quero, \\ E pode ser que bem cedo, \\ Uma cousa divertida \\ Um jornal para brinquedo.
}

67. Robert Moses Pechman, Cidades Estreitamente Vigiadas, pp. 82-83. 


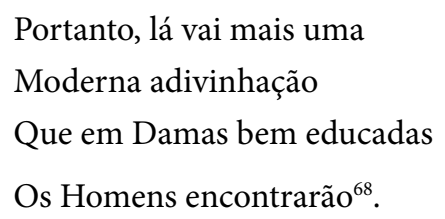

Desde o início desse poema até o trecho aqui reproduzido, Paula Brito enaltece as qualidades femininas, diz que aprendeu a prezá-las com seus e pais e que transmitia esses valores a seus filhos. Trata-se de uma temática moralizante, o respeito à mulher, embora nesse mesmo texto ele afirmasse que a Marmota era um jornal de entretenimento. A questão dos costumes era tão presente na folha, que a resposta à adivinhação insinuada nos dois últimos versos desse trecho era "amabilidade".

No aniversário de cinco anos da Marmota, um texto assinado por “T." relembra o início da revista e a motivação para sua criação:

Era no meio de uma capital, cujo luxo cresce na razão da sua população, que notamos que não havia um periódico digno das famílias, que entretivesse o belo sexo; mas alheio às discussões políticas, às ridículas personalidades, às intrigas particulares, às travessuras dos partidos, e onde se não lessem esses fastidiosos anúncios, jactâncias pueris, desprezíveis serviços de inconsiderados e impertinentes amigos, e estúpidos admiradores; e, finalmente, essas pesadas colunas de importuna, insulsa e ronceira prosa metrificada, à qual a ignorância impinge o nome de verso ${ }^{69}$ !

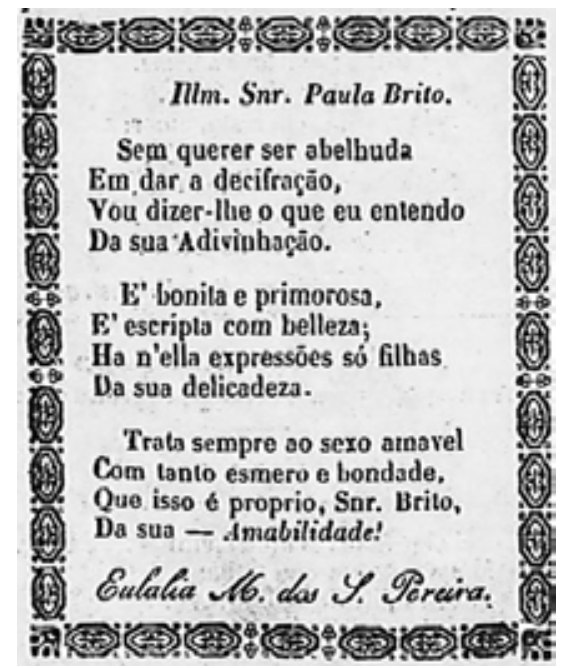

Figura 28. Resposta de uma leitora à adivinhação proposta por Paula Brito nos versos "Eu, e as Minhas Lembranças".
Mais uma vez, a própria Marmota divulga os objetivos de sua publicação: produzir matérias que pudessem ser consumidas pela família carioca, especialmente as mulheres, deixando de lado temas políticos, intrigas da sociedade, anúncios enfadonhos e textos bajuladores. Nesse texto, a poesia recebe destaque, pois é expressa a intenção de trazer literatura da melhor qualidade para instrução e divertimento.

A presença de artigos moralizadores já podia ser detectada desde o número de estréia da Marmota, que publicou o texto "Variedade - Os Hipócritas", em cujas primeiras linhas lê-se: "É hipócrita o mercador que dá esmola em público e leva usuras em oculto; é hipócrita a viúva que sai mui sisuda no gesto e no hábito e dentro em casa vive como ela quer e Deus não manda"70. Havia também uma série de matérias com títulos similares e aparecimento esporádico, semelhantes ao que hoje se entende por seção especializada, cujos nomes variavam entre

68. Marmota Fluminense, n. 440, p. 1, 31 jan. 1854.

69. Idem, n. 503 , p. 1,8 set. 1854 .

70. A Marmota na Corte, n. 1, p. 1, 7 set. 1849. 
"Visão Crítica, Moral e Salutar", que em outubro de 1849 tratou sobre o tema religião ${ }^{71}$, "Vista Científica, Moral e Higiênica", que condenou o exagero de carne na dieta das pessoas ${ }^{72}$, "Vista Instrutiva", que abordou os preceitos da educação ${ }^{73}$, e "Vista Séria e Instrutiva", que trouxe informações sobre higiene e salubridade $\mathrm{e}^{74}$.

Embora a Marmota, em sua vertente civilizadora, procurasse sempre manter suas leitoras a par das tendências da moda, as preocupações formadoras da folha também recaíam sobre esse assunto. Como exemplo de matéria que pretendeu corrigir os costumes relativos aos excessos das damas, podese citar "A Vaidade", em que se desaprova as "mulheres desmioladas" que por ostentação exigem que seus maridos comprem todos os enfeites que elas desejam, nem que para isso seja necessário roubar ${ }^{75}$, e "A Roupa ou o Vestuário", no qual se censura os alfaiates na corte que ganham mais que bacharéis de direito e mesmo que desembargadores por conta da "mania das modas" e "vaidade do luxo"76.

Em setembro de 1850, "Os Deveres dos Esposos" que buscava chamar a atenção para a moral dentro do casamento e estava sendo divulgado no Grátis, passou a aparecer na Marmota, atendendo aos pedidos de seus leitores, como argumentou Paula Brito $^{77}$. Trata-se, na verdade, do primeiro capítulo da obra La Morale Universelle, ou Les Devoirs de l'Homme Fondés sur la Nature, do Barão de Holbach, publicada em 1776. Embora o autor da obra se definisse como ateísta, determinista e materialista, ele tinha sido, paradoxalmente, um grande reformador social.

Novamente abordando a relação entre os sexos, a revista de Paula Brito divulgou o artigo "O Pudor da Mulher" do qual se transcreve o início:

O pudor é um dos mais belos atrativos de que a mulher está ornada: formosa, espirituosa, viva, graciosa, ela atrai tanto pelos encantos de seu espírito, como por suas qualidades físicas; porém ao mesmo tempo sabe dar valor aos seus favores, rodeada de uma barreira, cujo efeito é de ativar os desejos e de os tornar mais duráveis. É mister não desconhecer que os homens querem triunfos, não os ambicionam fáceis, e que a natureza, que nada faz sem um fim, quis, por um dique, suspender os gozos a fim de acumular de alguma maneira os resultados ${ }^{78}$.

Essa poderia ser uma leitura destinada tanto a rapazes como a moças, mas sabendo que o público-alvo da folha era constituído sobretudo por mulheres, é possível inferir que o autor buscava infundir em suas leitoras os princípios de decência considerados adequados para a época.

Nessa mesma linha moralizante, Paula Brito transcreveu em sua revista uma "Carta do Monsenhor José Antônio Marinho a Seus Discípulos”. Sobre esse religioso, Machado de Assis registrou: "Monsenhor Reis era um dos sacerdotes mais populares, entre nós; ele, o Mont'Alverne, monsenhor

71. A Marmota na Corte, n. 16, pp. 2-3, 30 out. 1849.

72. Idem, n. 94 , pp. 1-2, 20 set. 1850.

73. Idem, n. 94 , pp. 2-3, 20 set. 1850 .

74. Idem, n. 95, pp. 1-2, 24 set. 1850 .

75. Idem, n. 54, pp. 1-2, 22 mar. 1850.

76. Idem, n. 94 , pp. 3-4, 20 set. 1850.

77. Idem, n. 95, pp. 2-3, 24 set. 1850.

78. Idem, n. 225, pp. 1-2, 9 jan.1852. 
Marinho, frei Antônio, o franciscano, foram os nomes que a nossa infância ouviu pronunciar com mais freqüência e admiração [...]"79. A carta publicada na Marmota era dirigida a crianças, a quem o monsenhor pedia que obedecessem a seus pais:

[...] vede bem, meninos, na idade em que estais; sois ignorantes, fracos, e como que cegos; Deus vos deu em vossos pais os mestres que vos instruem, os sustentáculos em quem vos apoiais, os guias que vos mostram o caminho, que convém sigais $[\ldots]^{80}$.

Também pensando na "geração moderna", Paula Brito decidiu dar uma nova edição das Fábulas de Esopo em português na Marmota. No prólogo, ele afirma que "nada pois é mais útil e interessante do que as fábulas, as novelas, todas as vezes que são compostas de sorte que delas se possa tirar a moral"81. De modo que fica evidente que sua intenção era realmente oferecer a seus leitores uma nova fonte moralizadora. O tipógrafo certamente conseguiu sensibilizar seu público, pois depois recebeu uma carta assinada por "Seu Constante Leitor", em cujo início se lia: "Vosmecê publicou na Marmota uma elegante tradução das Fábulas de Esopo, para introduzir no povo brasileiro as lições de moralidade, que nelas se contêm. Além destas, vosmecê tem dado à luz as do poeta espanhol
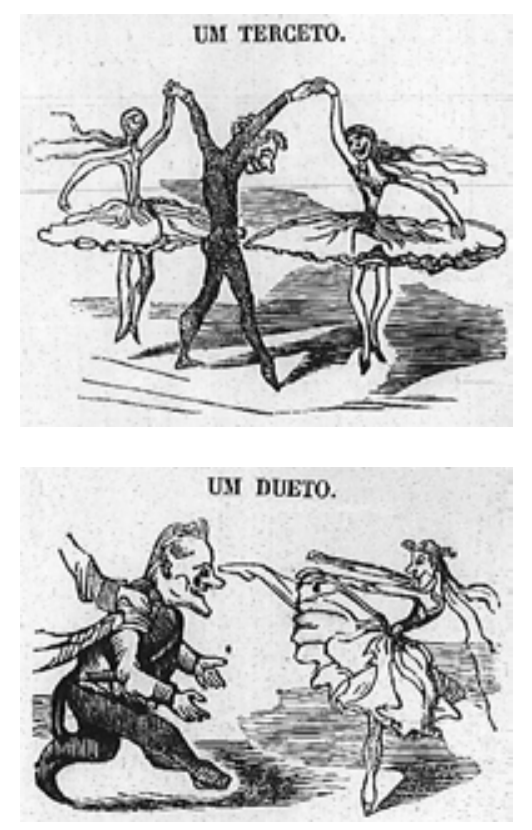

Figura 29. Exemplos de passos para a matéria "A Dança Moderna".
Yriarte" 82 . O leitor continuava seu texto discorrendo sobre o poeta inglês John Gray que havia elaborado algumas fábulas para a instrução de seus discípulos e remetia à Marmota a tradução, feita pelo visconde de Cairu, da primeira alegoria de Gray.

O proprietário da Marmota decidiu também criar um espaço destinado a publicar novamente trechos de diversas obras já editadas e consideradas essenciais para a cultura de uma família. Essas matérias seriam publicadas sob o título "Instrução Familiar", sendo que o primeiro desses artigos foi "Chefe de Estado e Chefe de Família"»3.

Os elementos civilizadores igualmente foram parte do conteúdo da Marmota. A idéia era sempre trazer aos leitores da revista informações capazes de conferir-lhes mais cultura e refinamento, aproximando-os do padrão europeu. As matérias consideradas instrutivas podiam ser tanto transcritas como adaptadas de outros periódicos, estrangeiros ou nacionais, redigidas pelos colaboradores da revista ou mesmo remetidas por leitores. Este último foi o caso de "Civilização", uma correspondência estampada no jornal:

79. Machado de Assis, Crônicas, vol. 4, pp. 175-176.

80. Marmota Fluminense, n. 423, pp. 2-3, 2 dez. 1853.

81. Idem, n. 440, pp. 1-2, 31 jan. 1854.

82. Idem, n. 584, p. 2, 22 maio 1855.

83. Idem, n. 443, p. 1, 10 fev. 1854. 
Tenho-te falado, nas minhas últimas, de alguns de nossos costumes públicos e domésticos que se não podem sustentar em face da civilização a que nossa terra aspira, hoje te ocuparei com uma pequena descrição que [...] representa verdadeira bisonhice e o atrasamento dos nossos costumes sociais dos tempos dos vice-reis, querendo dar o tom na sociedade no tempo do Senhor dom Pedro II. [...] imagina também qual não seria a minha surpresa quando, acabando de subir as escadas, achei-me em um salão, dividido ao meio por uma barreira de grades de pau, com uma cancela, que vinham até a altura do queixo de um homem: e vi de uma parte as senhoras todas, e de outra os homens todos. Estava na Sociedade Filarmônica da Capital do Império do Brasil ${ }^{84}$ !

O autor dessa carta chegou a chamar a situação descrita de "sátira afrontosa à mocidade fluminense" e de "ausência absoluta de boa educação".

Sempre tentando cultivar os melhores hábitos em seus leitores para a vida em sociedade, a Marmota chegou a publicar a matéria "O Prazer do Banho". Neste texto são descritas as vantagens físicas e psicológicas de lavar-se, "repara as fadigas, restabelece o equilíbrio das funções da vida, descentraliza os fluidos reconcentrados, e acalma as exacerbações do cérebro". Além disso, os banhos "vigoram as forças perdidas e nos lavam o corpo, pondo-nos em estado de andarmos na sociedade sem causar nojo aos nossos semelhantes, nem incomodar o nariz dos que junto de nós se assentam" ${ }^{85}$.

Sob o título "A Dança Moderna”, a Marmota publicou alguns artigos extraídos da L'Illustration de Paris apresentando a seus leitores - tanto aos de fora da corte, como àqueles que nela residiam, mas não costumavam ir aos teatros - a dança contemporânea. A idéia era precisamente informar o que há tempos já ocorria nos salões da Europa para que os brasileiros não ficassem desatualizados ${ }^{86}$.

Outra matéria que tinha por objetivo atualizar os leitores da Marmota sobre demonstrações de refinamento na época foi “Os Fumantes da Moda”. Seu autor, José Antônio, é categórico ao afirmar: "Não resta pois a menor dúvida, que, presentemente o charuto reina e governa a alta sociedade; que o charuto, enfim,
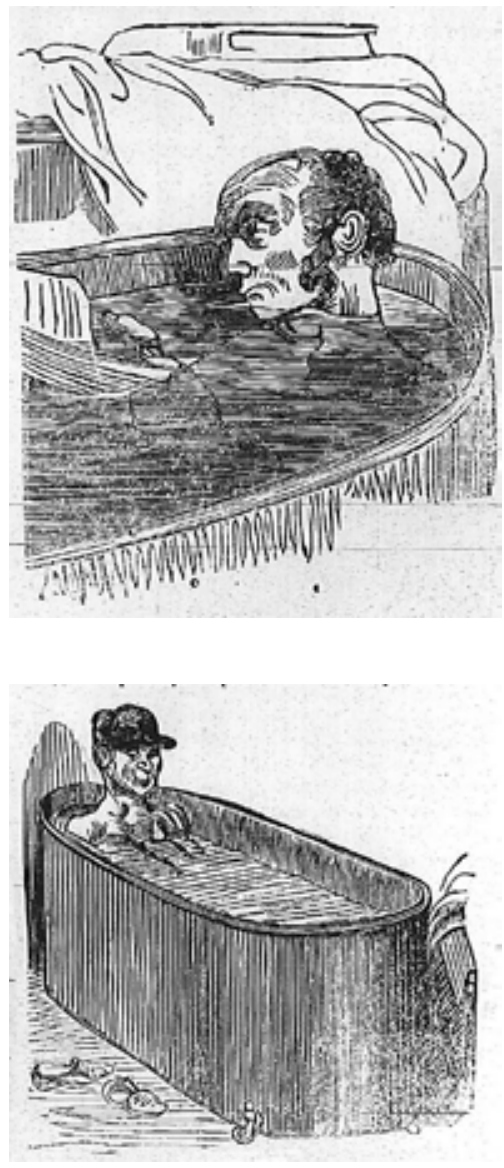

Figura 30. llustrações do artigo "O Prazer do Banho" na Marmota.

84. A Marmota na Corte, n. 37, p. 3, 18 jan. 1850.

85. Marmota Fluminense, n. 289, pp. 2-3, 20 ago. 1852.

86. Idem, n. 298, pp. 1-2, 21 set. 1852. 

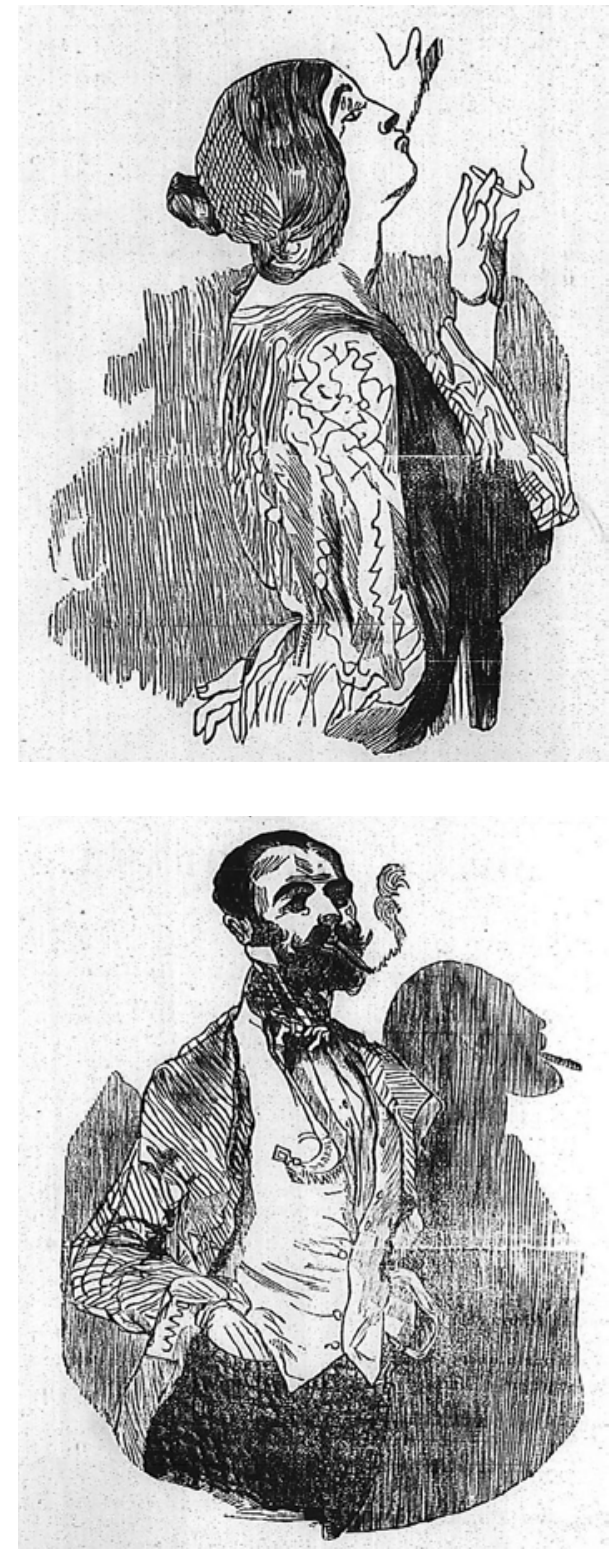

Figura 31. Gravuras para o artigo "Os Fumantes da Moda".

fuma passa por bisonho, e mostra não seguir a estrada da civilização e do progresso!" ${ }^{87}$. Boa parte do texto trata de elogiar o charuto, em detrimento do tabaco em pó, que era aspirado pelo nariz.

Sendo um periódico abertamente destinado ao público feminino, não faltaram à Marmota assuntos considerados interessantes às mulheres da época. Desde textos destinados a valorizar o espírito feminino, como "A Mulher" no qual se fala que é às mulheres que todos devem suas vidas, inclusive os escritores que injustamente as acusam de não ter a mesma capacidade intelectual que os homens ${ }^{88}$, até outros com certo teor orientador, como "As Moças". Neste último, Próspero Diniz aconselha as jovens cariocas a se portarem de forma adequada para não "perderem conceito" ou mesmo "nunca acharem casamentos", entre as atitudes que devem ser evitadas são citadas: excesso de risadas e de conversas, trejeitos e "macaquices" para tentar agradar forçosamente seu interlocutor, passar muito tempo nas janelas, falta de cuidado com o vestuário e com o corpo, dançar demais em bailes, mostrar muito desejo em casar, mentir, não saber costurar e cabelos mal cuidados ${ }^{89}$. Tratase, como anteriormente mencionado, de um artigo com função semelhante à exercida pelos manuais de civilidade da época.

Uma iniciativa notável de Paula Brito foi a Biblioteca das Senhoras, uma forma engenhosa de oferecer um produto a um público específico e, ao mesmo tempo, dar expandir a diretriz formadora de seu periódico para a esfera editorial. Segundo o tipógrafo, "esta obra, extraída da - Moral DA InfÂNCIA - Livro dos Domingos - e de outros deste gênero, é a mais interessante possível e compõe-se de peças escolhidas pelo editor para instrução e recreio da mocidade, principalmente das pensionistas de colégio"90. A Biblioteca da Senhora era composta em dois volumes contendo oito romances.

Os temas sobre moda foram igualmente muito freqüentes na Marmota. Já em 1850 mencionouse a intenção de iniciar os artigos sobre esse assunto: "A redação, para torná-la [Marmota] cada vez

87. Marmota Fluminense, n. 396, pp. 2-3, 30 ago. 1853.

88. A Marmota na Corte, n. 16, pp. 1-2, 30 out. 1849.

89. Idem, n. 35, pp. 2-3, 11 jan. 1850.

90. A Marmota, n.1.129, p. 4, 27 jan. 1860. 
mais interessante, mandou subscrever em Paris os mais acreditados jornais do grande tom, para servirem-lhe de guia nos artigos de modas, que começará breve a publicar [...]"191. E logo anunciou quais periódicos franceses serviriam de subsídios às matérias cariocas: Bom-Tom, Foullet, Caprice e Petit-Courrier de Dames ${ }^{92}$.

Em um de seus artigos sobre moda, a Marmota informou que segundo as revistas parisienses, com a mudança de estação que se aproximava, os tecidos empregados na fabricação de vestidos estavam sendo alterados. No mesmo artigo, noticiou-se que as modistas brasileiras sempre aguardavam inquietas o retorno do verão, uma vez que era impossível reproduzir no Rio de Janeiro os modelos do inverno europeu ${ }^{93}$.

Essa problemática da apropriação da cultura francesa é descrita na obra História da Vida Privada no Brasil:

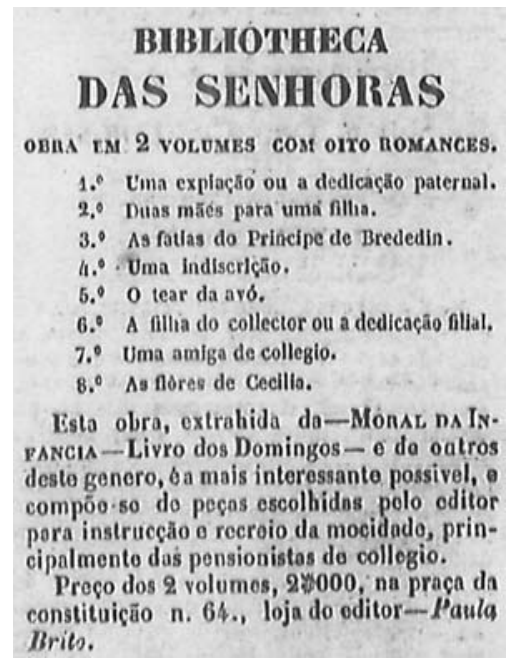

Figura 32. Anúncio da Biblioteca das Senhoras.

As crônicas dos jornais e das revistas faziam revisões semanais ou quinzenais de bailes e episódios recém-acontecidos, davam conselhos sobre o dia-a-dia, e tinham nas mulheres o seu público-alvo. O inverno, mesmo o tropical inverno da corte, levava o clima da cidade a aproximar-se do de Paris.

[...]

Tais publicações, ao mesmo tempo que informavam, conformavam certos tipos de comportamento, os quais, criados na corte com base em referências estrangeiras, eram propagados pelas províncias como modelos a ser seguidos ou como normas de conduta $^{94}$.

Na condição de meio de comunicação carioca do século XIX, a Marmota incumbe-se desse papel civilizador, que não abrange somente a esfera da moralidade. O propósito formador, nesse caso, se dá também por meio da busca de um estado de atualidade nos costumes, ditado, naquele momento, por Paris.

E é possível perceber que o jornal, de fato, tinha força para criar esse tipo de interferência civilizatória na conduta de seus leitores, como confirmado pelo exemplo a seguir:

Depois que a Marmota noticiou às suas leitoras a aparição desta moda [os penteados à Maria Stuart e à Chambord], temos visto muitas moças assim penteadas, e algumas, sabemos, pelas mãos dos cabeleireiros da rua do Ouvidor ${ }^{95}$.

91. A Marmota na Corte, n. 85, p. 1, 20 ago. 1850.

92. Idem, n. 125, p. 1, 21 jan. 1851.

93. Idem, n. 112, p. 1, 22 nov. 1850.

94. Ana Maria Mauad, "Imagem e Auto-imagem do Segundo Reinado", em Luiz Felipe de Alencastro (org.), História da Vida Privada no Brasil, pp. 208-209.

95. A Marmota na Corte, n. 140, p. 1, 14 mar. 1851. 


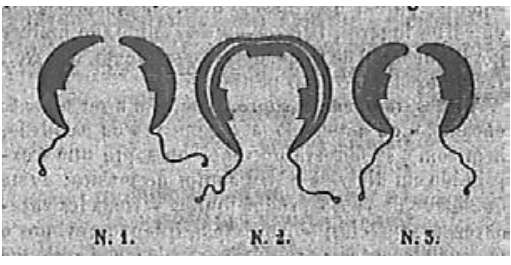

Figura 33. Modelos de cabelos: (1) penteado à Maria Stuart, (2) penteado à Chambord e (3) bandós (Marmota, 14 mar. 1851).

Tanto as ilustrações que o jornal incluía em suas páginas, para explicar, por exemplo, como se faziam determinados penteados, quanto os próprios figurinos com as últimas tendências de Paris, distribuídos aos assinantes do periódico, eram ferramentas empregadas para atualizar seus leitores. Do mesmo modo, os artigos em que se descreviam os bailes da cidade e os trajes de cada uma das figuras notórias funcionavam como uma espécie de instrumento de coerção, pois certificavam que a elite vestia exatamente o que o jornal pregava, a moda parisiense em suas intenções mais recentes.

O entretenimento igualmente esteve presente desde a primeira Marmota, na qual foi publicada uma charada que Próspero Diniz diz ter proposto ao Imperador, que em instantes a decifrou. Além dos jogos, a folha também publicava anedotas e breves textos de cunho humorístico, como o "Deus te Livre, Leitor!":

De negócio em mãos da Justiça.

De vizinhos que te incomodam.

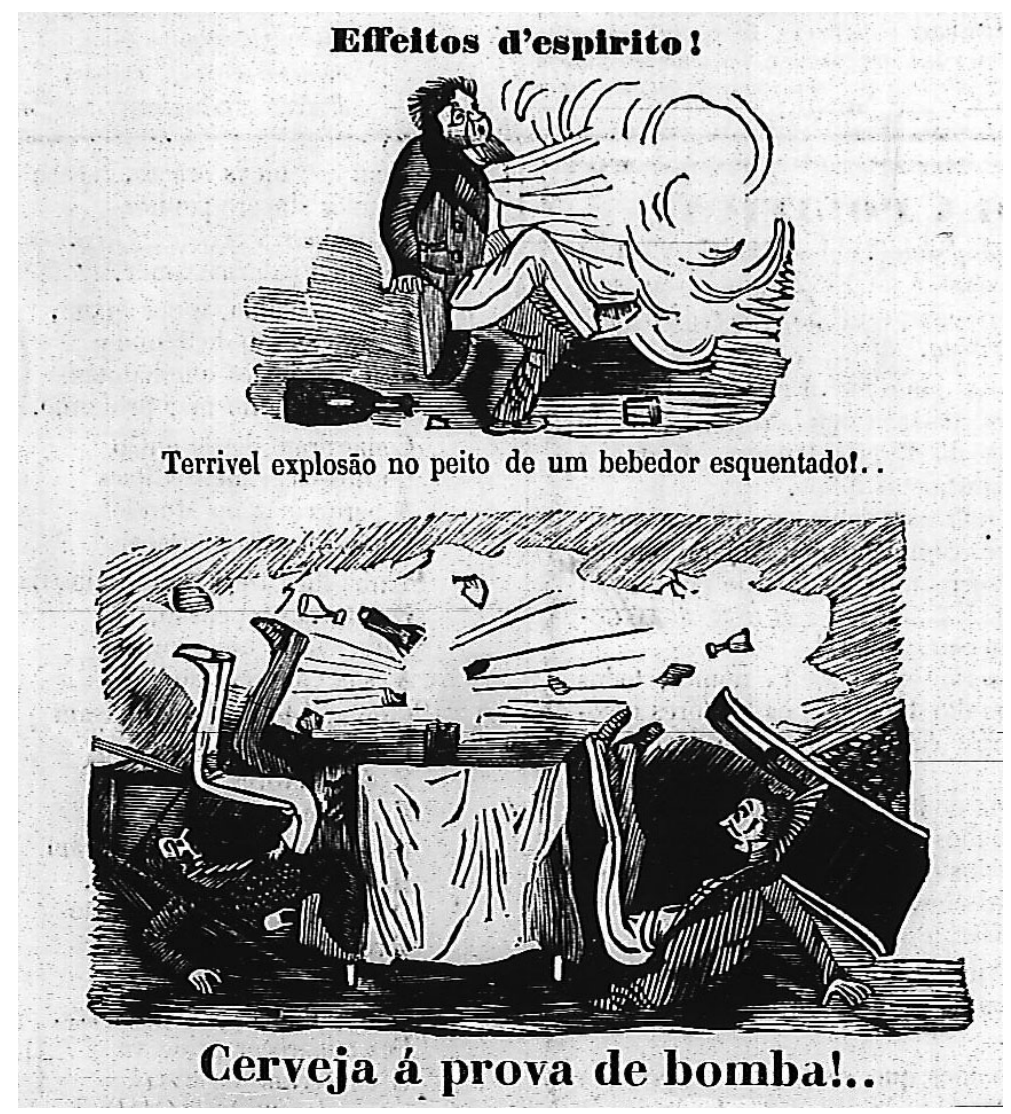

Figura 34. Charge sobre consumo de bebida alcoólica (Marmota, 26 nov. 1852). 
De inspetor de quarteirão, que inspeciona demais.

De exercícios findos no Tesouro Nacional.

De mulher, cuja balda acabe em eira ${ }^{96}$.

A Marmota também chegou a publicar charges, que apesar de não representarem críticas diretas à política, satirizavam alguns hábitos da época. Uma delas foi "A Febre na Praça em 1854", que gracejava com o tumulto que ocorreu entre as pessoas que tentavam comprar ações do Banco do Brasil, Banco Hipotecário e das empresas de estrada de ferro e de iluminação a gás ${ }^{97}$. A folha também reproduziu caricaturas veiculadas no francês Le Journal pour Rire, para, segundo sua redação, tornar a publicação "o mais variada e interessante que for possível"98.

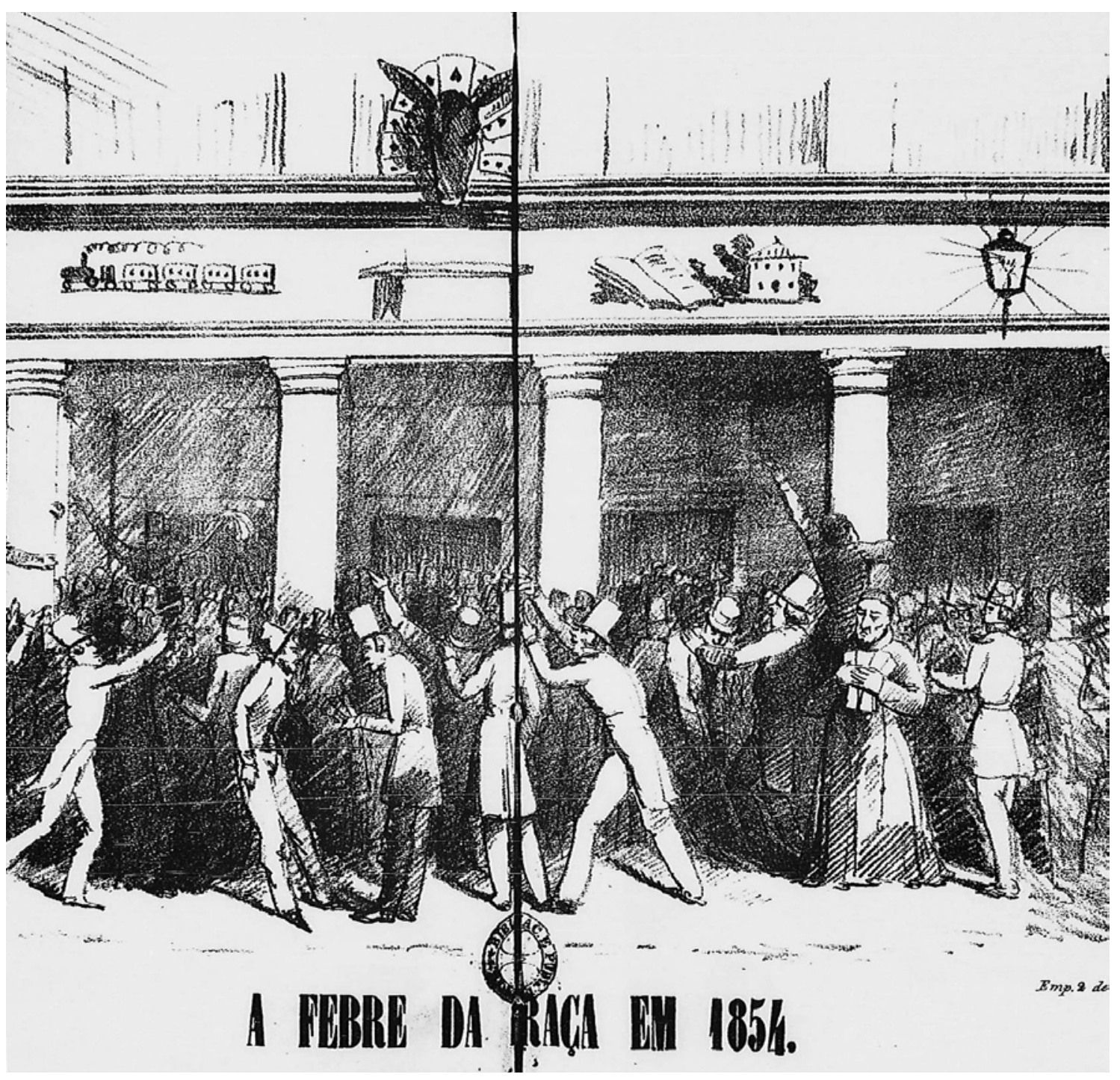

Figura 35. Charge "A Febre na Praça em 1854".

96. A Marmota na Corte, n. 136, p. 4, 28 fev. 1851.

97. Marmota Fluminense, n. 476, 6 jun. 1854.

98. Idem, n. 467, p. 1, 5 maio 1854. 


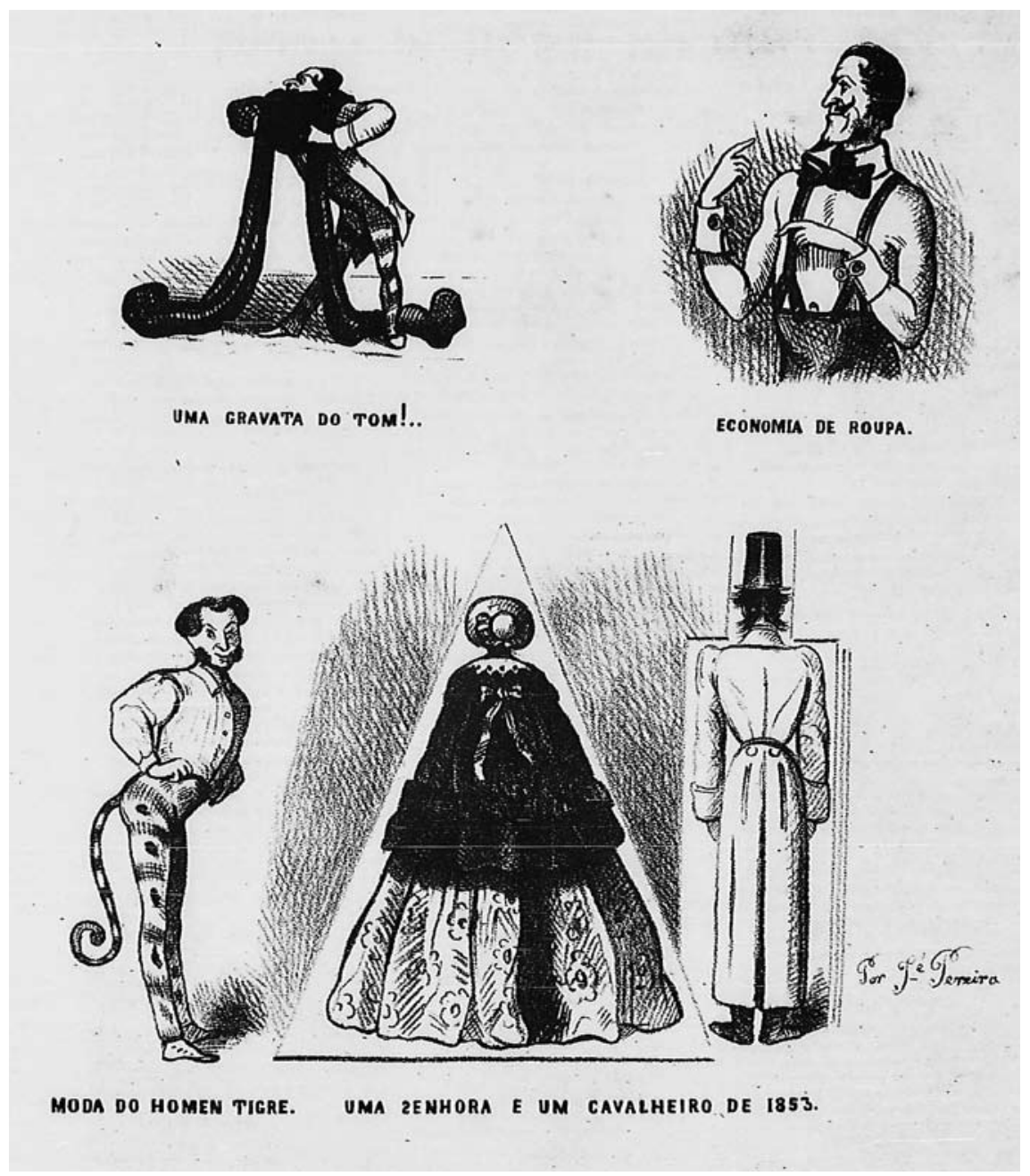

Figura 36. Essas caricaturas até foram esclarecidas pela redação da Marmota. "Uma gravata do tom": os embaraços que enfrenta o homem que quer acomodar no pescoço uma gravata enorme; "Economia de roupa": o homem sem camisa, vestindo punhos e colarinhos, pode se sentir na moda sem ter que gastar dinheiro com roupa lavada; "Moda do homem tigre": "um cavalheiro de suíças e cabelo à moda, calças pintadas e requebrando-se todo, pondo-se-Ihe um rabo é um tigre perfeito"; "Uma dama e um cavalheiro de 1853": a moça vestida no rigor da moda mais lembra um triângulo, enquanto o rapaz se parece com um retângulo (Marmota, 5 maio 1854).

Como periódico dedicado a entreter e instruir seus leitores, a Marmota não podia desdenhar as manifestações culturais ligadas à música e ao teatro. Em suas páginas foram publicados lundus e modinhas, sem esquecer as valsas, polcas e outras partituras que eram distribuídas gratuitamente aos assinantes da revista.

A "Ária da Negrinha-monstro", por exemplo, com letra de Paula Brito e música de J. J. Goyano saiu na revista em $1851^{99}$. Dois anos depois, foi publicado o lundu "Ponto Final", criado pela mesma dupla ${ }^{100}$. No entanto, a composição mais conhecida divulgado na Marmota foi o "Lundu

99. A Marmota na Corte, n. 136, pp. 3-4, 28 fev. 1851.

100. Marmota Fluminense, n. 383, pp. 3-4, 15 jul. 1853. 
da Marrequinha", resultado da parceira entre Paula Brito e o músico Francisco Manuel da Silva ${ }^{101}$.

A folha também fazia circular notícias sobre o teatro. Em 1852, informava sobre o sucesso alcançado pela senhora Stolz no papel de protagonista da tragédia lírica Semiramide, em que ela teria conquistado ainda mais admiradores que em A Favorita.

No mesmo ano, a revista divulgou um artigo extraído do periódico milanês Cosmorama Pittoresco, "A Malibran Preta"102. O título aludia a Maria Malibran, famosa soprano francesa da primeira metade do século XIX. No entanto, a cantora de quem o jornal italiano falava era uma negra, Maria Martinez, que por conta de seus padrinhos teve a oportunidade de aprender canto lírico. Essa moça acabou atraindo a atenção da rainha espanhola $e$ tinha se tornado a atração mais disputada de Paris.

Madame Charton encantou de tal maneira a redação da Marmota em sua interpretação da ópera de Bellini, La Sonnambula, no Teatro Lírico Fluminense que já estando composto o número seguinte da revista, decidiu-se criar um suplemento apenas para comentar sua atuação. Fala-se que: "Quem viu Mme. Charton cantar e representar, morre para vê-la outra vez, e sempre; quem não teve a satisfação de aprecia-la, tenha pesar disso e possua o desejo de vê-la, de admirá-la e de aplaudi-la, que o há de fazer freneticamente" ${ }^{103}$.

Para permanecer durante doze anos ininterruptos no mercado, exercendo seu papel de meio de comunicação moralizador e civilizador, a Marmota necessitava de recursos materiais de sobrevivência. É fácil notar que, nessa época, para a maioria dos periódicos científico-literários foi difícil, e até mesmo impossível, manter-se em circulação

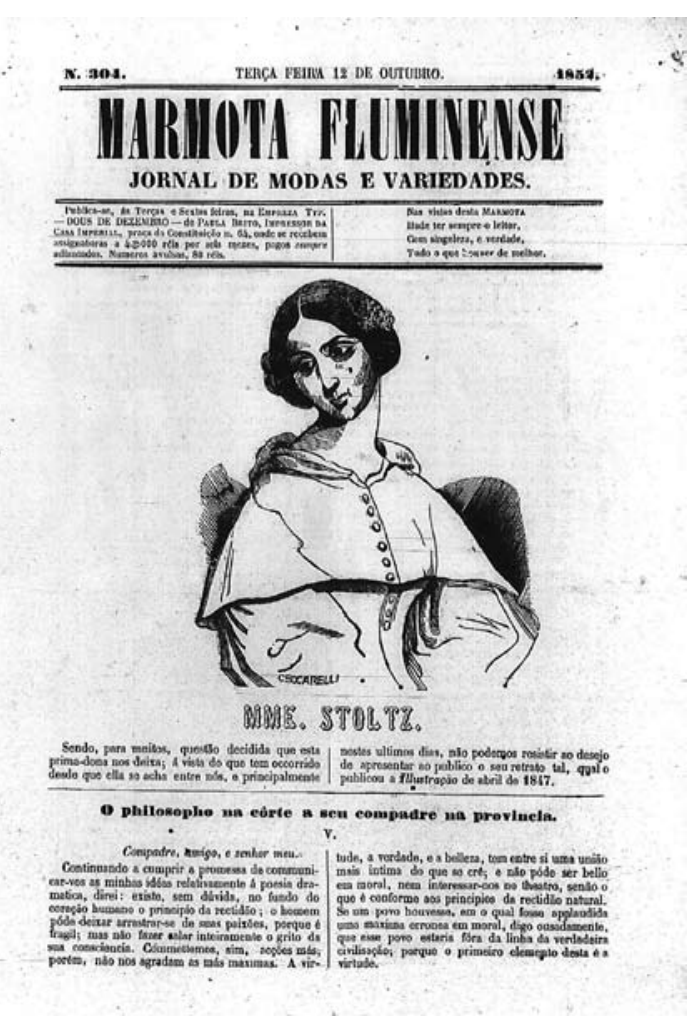

Figura 37. Retrato de madame Stolz ocupando grande parte da primeira página da Marmota (12 out. 1852).

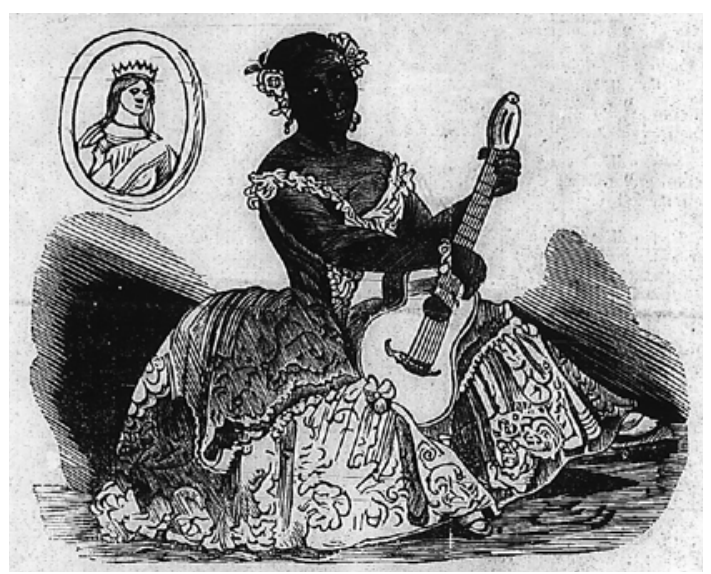

Figura 38. A gravura da "Malibran preta" estampou a primeira página da Marmota Fluminense.

101. Idem, n. 390, p. 4, 9 ago. 1853.

102. Idem, n. 301, p. 1, 1 out. 1852.

103. Suplemento à Marmota Fluminense n. 481, “Teatro Lírico Fluminense”, 23 jun. 1854. 
por muito tempo, haja vista o tempo médio de vida de alguns deles: Minerva Brasiliense, 1843 a 1845; Lanterna Mágica, 1844 a 1845; Íris, 1848 a 1849; O Beija-flor, 1849-1854; O Jornal das Senhoras, 1852 a 1855; O Espelho, 1859 a 1860.

Como Francisco de Paula Brito, tipógrafo sabidamente de escassos recursos financeiros, teria conseguido manter seu jornal por tanto tempo? A Marmota certamente não era a única folha nesse segmento de modas, literatura e entretenimento. E nem tampouco se pode imaginar que a oficina tipográfica de Paula Brito tenha, sozinha, sustentado o periódico por um período tão longo.

Neste estudo, levanta-se a hipótese de que, muito além de buscar valorizar e disseminar a cultura, a Marmota tenha se utilizado dela para sua subsistência. Desse modo, a divulgação de poesias, de romances nacionais e de novos autores, talvez tenha sido um modo de atrair os leitores e garantir a circulação do jornal. Principalmente na segunda metade do século XIX, quando se começou a edição de romances e autores brasileiros e a se fomentar a idéia de que era necessário "construir" uma cultura nacional.

Sabe-se que as seguintes obras foram publicadas originalmente na Marmota, antes de serem editadas em volume: Maria ou a Menina Roubada, de Antônio Gonçalves Teixeira e Sousa, de 1852 a 1853; A Carteira de Meu Tio e O Forasteiro de Joaquim Manuel de Macedo, ambos em 1855; O Canário, Conto do Cônego Schmidt, de Guilherme Cândido Bellegarde (o tradutor não é identificado), em 1856; O Prestígio da Lei, de Manuel de Araújo Porto-Alegre, em 1859; e Queda que as Mulheres Têm para os Tolos, tradução de Machado de Assis, em 1861.

A presente pesquisa pôde concluir que

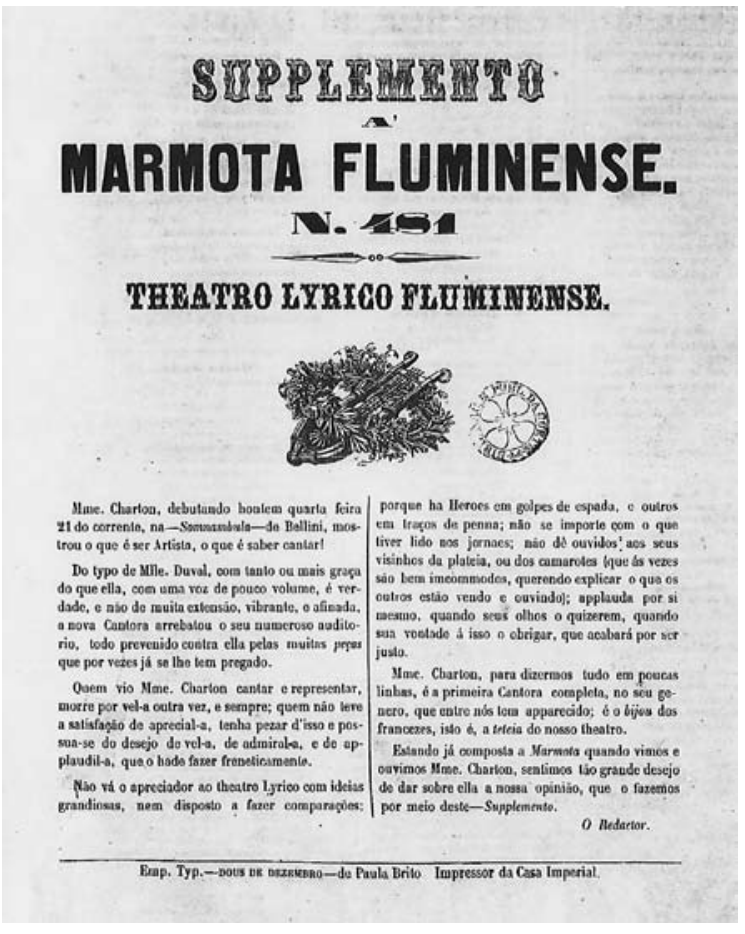

Figura 39. Suplemento da Marmota dedicado à apresentação de madame Charton no Teatro Lírico Fluminense. mais comum que essa situação - em que a primeira edição da obra se deu pelo jornal - foi a de uma nova divulgação no periódico de obra já editada em volume pelas oficinas de Paula Brito. Foi o caso de: Dores e Flores, de Augusto Emílio Zaluar, que foi editado em 1851 e divulgado no mesmo ano na Marmota; O Primo da Califórnia (ópera) e Vicentina (romance), ambos de Joaquim Manuel de Macedo, a primeira editada em 1858 e divulgada no jornal no mesmo ano, e o segundo editado em 1853 e republicado em 1854; Elogio Acadêmico da Senhora D. Maria I, de José Bonifácio de Andrada e Silva, editado por Paula Brito em 1839 e reproduzido em 1857; As Fatalidades de Dous Jovens (em volume e na folha no mesmo ano, 1856), Os Três Dias de um Noivado (editado em 1844 e divulgado no jornal em 1857), Tardes de um Pintor ou Intrigas de um Jesuíta (foi publicado pela Tipografia de Teixeira e C. ${ }^{a}$ em 1847 e veiculado na Marmota 
em 1857 e 1859) ${ }^{104}$, O Filho do Pescador (saiu como volume 1843 e republicado no jornal em 1859), Gonzaga ou a Conjuração do Tiradentes (o primeiro volume saiu pela Tipografia de Teixeira e C. ${ }^{a}$ em 1848 e o segundo, em 1851, foi republicado na Marmota em 1860), todos de Teixeira e Sousa; Excertos das Memórias e Viagens do Coronel Bonifácio do Amarante, de Tibúrcio do Amarante (pseudônimo de Manoel de Araújo Porto-Alegre), que saiu em volume em 1852 e na Marmota em 1859; A Filha do Coletor ou o Amor Filial, tradução de Bráulio Cordeiro, que foi editada em 1859 e divulgada no mesmo ano no jornal; Paulo, romance de Bruno Seabra, que se tornou volume e saiu na Marmota em 1861.

A iniciativa de promover nova edição de uma obra no jornal, em detrimento de reeditá-la na forma de volume, pode ser justificada do ponto de vista econômico com pelo menos duas razões. Por um lado, o custo de produção era diminuído, pois não havia a despesa de impressão e encadernação do exemplar em livro. Por outro, como esses textos já tinham sido publicados, era possível conhecer sua recepção entre os leitores, logo, presume-se que Paula Brito tenha escolhido para

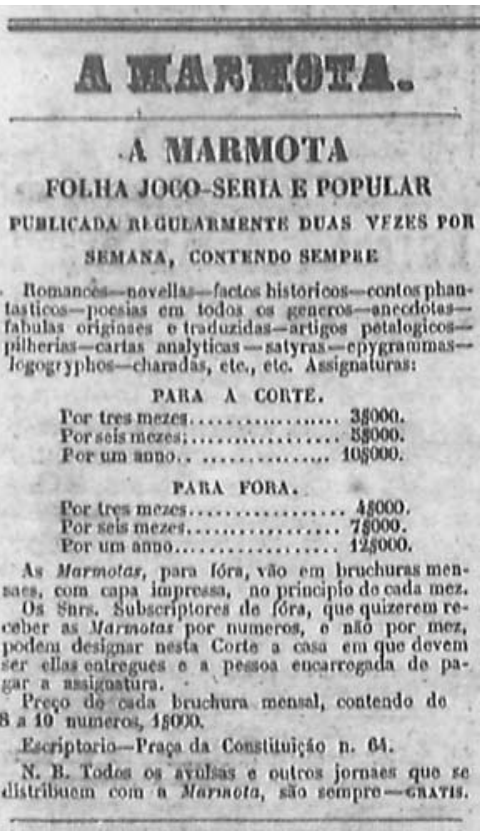

Figura 40. Nota informando que a Marmota era remetida na forma de brochuras mensais para fora da corte (27 jan. 1860). a Marmota os conteúdos mais bem aceitos. O tipógrafo também lançou mão desse recurso ao trazer novamente a público, em seu jornal, obras mais antigas como o poema épico Caramuru, de frei José de Santa Rita Durão, e O Uragaui, de José Basílio da Gama, ambos em $1855^{105}$.

Excluindo-se os trabalhos já citados, foram ainda publicados como folhetins na Marmota as seguintes obras: Judith ou o Camarote da Grande Ópera de Paris, de Eugène Scribe; Uma Fatalidade, de Méry; D. Narcisa de Villar, da Indígena do Ipiranga (Ana Luísa de Azevedo e Castro); Fases da Vida, de José Rufino Rodrigues Vasconcellos; É Preciso que uma Porta Esteja Aberta ou Fechada, adaptação da peça Il Faut qu'une Port Soit Ouvert ou Fermée de Musset; Joãozinho ou os Dous Soldos, tradução de Bráulio Cordeiro; A Sorte Grande, original alemão de Fanny Lewald, versão francesa por Ludwig Unger e Alphonse Pagés que serviu de base para a tradução para o português de J. J. da Rocha; A Providência, drama em três atos de José de Moraes Silva; Pedro Landais ou o Alfaiate Ministro, de Émile Souvestre; As Flores de Cecília, Th. Midy, entre outras

Em 1857, saiu na Marmota o artigo não assinado “As Letras no Brasil”. Trata-se de um desabafo de um "homem das letras" que reconhece que em seu país é impossível dedicar-se exclusivamente à literatura como profissão, para os amantes da pena, é preciso dedicar-se a ela apenas como prazer. Cita-se aqui o início dessa comunicação:

104. Segundo Paulo Berger em A Tipografia no Rio de Janeiro, p. 51, a Tipografia de Teixeira e C. a pertencia Antônio Gonçalves Teixeira e Sousa. Em 1849 foi comprada por Paula Brito, que se tornou sócio da empresa.

105. Em 1855 Paula Brito publicou também O Uraguai em volume. 
A nossa terra é por certo pouco literária; nisso não somos senão o malfadado eco de uma convicção que todos têm, e que muitos têm manifestado.

O Gênio de Homero, multiplicado pelo de Virgílio, se aparecesse entre nós, e compusesse sobre alguma grande tradição da pátria um poema mais sublime que a Ilíada, teria o desprazer de ficar com ele inédito, ou, se o imprimisse, de gastar para ter essa honra o seu dinheiro, e de andar se humilhando perante fastidiosos compradores para lhe aceitarem algum exemplar, para assinarem alguma subscrição ${ }^{106}$.

Paula Brito muitas vezes lançou mão do método de subscrição para imprimir obras em sua tipografia. Uma das obras editadas desse modo foi Lembranças de José Antônio, de José Antônio Frederico da Silva. Em 1857, lia-se na coluna "A Marmota": "Lembranças de José Antônio - Hoje distribuímos aos nossos leitores as listas para assinaturas, visto que a obra será publicada no final do corrente mês, e pedimos-lhes que as tomem em consideração"107. O mesmo aconteceu com Novas Poesias, de Faustino Xavier de Novaes, anunciou-se na Marmota: "Um volume de 300 páginas,
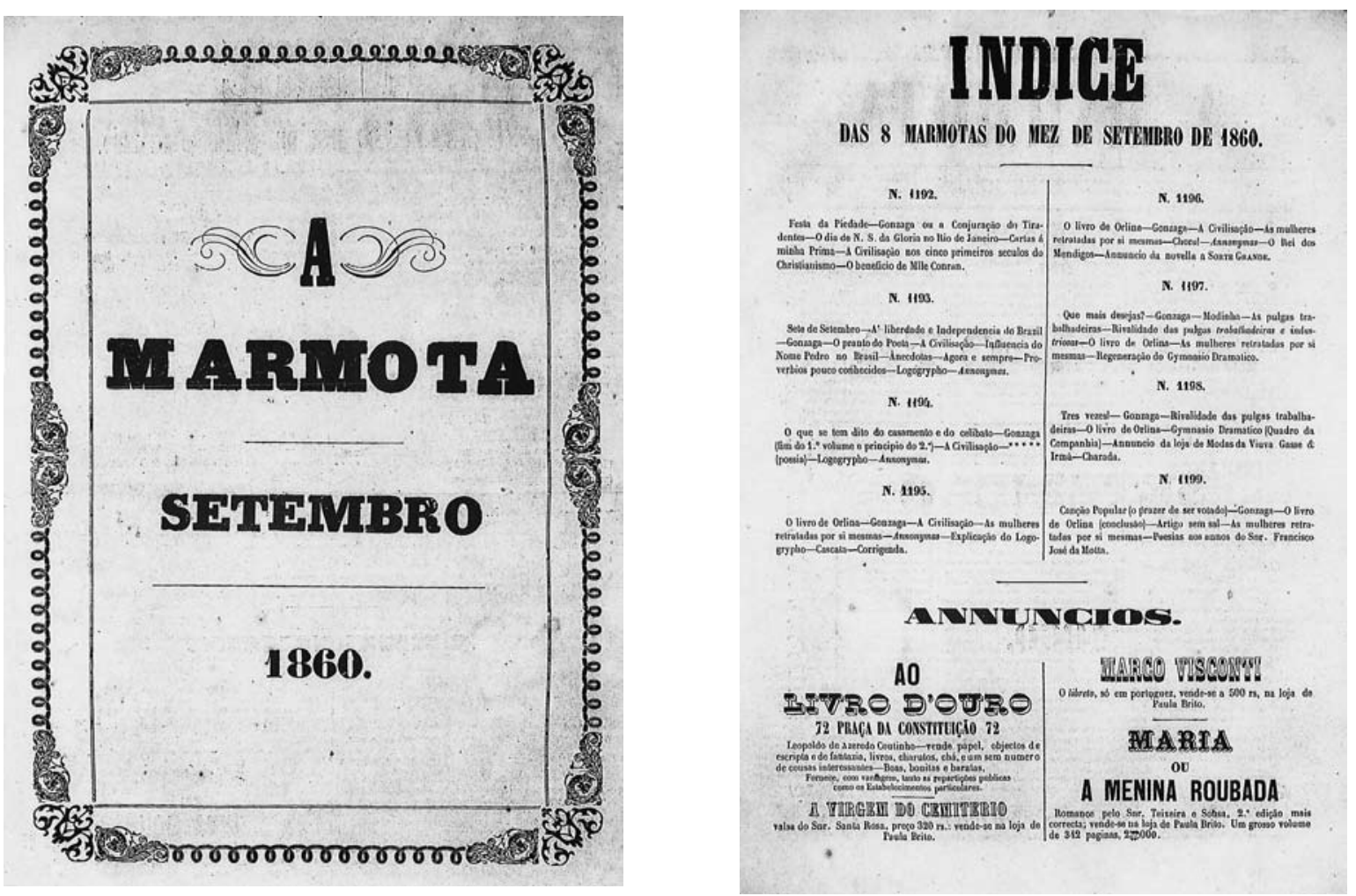

Figura 41. Capa e índice da brochura da Marmota de setembro de 1860, esse tipo de volume mensal era enviado para os assinantes de outras cidades. 
contendo poesias jocosas e satíricas, e um juízo crítico pelo Sr. Camilo Castelo Branco. Preço $3 \$ 000$ (moeda fraca). Subscreve-se na loja desta oficina, Praça da Constituição, n. 64”108.

Outra situação bastante peculiar era a das "amostras" de obras que Paula Brito veiculava em seu jornal. Os Últimos Cantos de Gonçalves Dias foram editados na tipografia de Paula Brito em 1851. Em março do mesmo ano, dois números seguidos da Marmota, por exemplo, traziam alguns poemas dessa obra. Segundo nota da redação, não cabia à folha avaliar os versos de alguém que já desfrutava de tanta fama, logo, esses trechos serviriam de base para que o leitor produzisse seu próprio julgamento. Isso era, certamente, um outro chamariz para o público. As pessoas buscariam adquirir a folha com o propósito de inteirar-se do lançamento, para conhecer a nova obra cujo autor integrava a galeria de célebres intelectuais brasileiros. Depois, caso os versos realmente despertassem interesse, iriam à loja de Paula Brito adquirir um exemplar.

Paula Brito também buscou alcançar, com sua folha, o público de fora corte. Para isso, a Marmota era remetida na forma de brochuras mensais. Além de mostrar o interesse do tipógrafo em fazer sempre crescer a circulação de seu jornal, essa iniciativa demonstra que realmente o periódico desprezava as matérias noticiosas, de consumo imediato. A literatura e o entretenimento, preocupações centrais da Marmota, poderiam ser desfrutados até meses depois de sua data de publicação original.

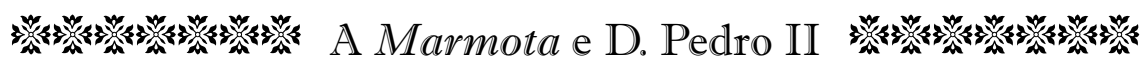

As matérias de exaltação e louvor oferecidas à família imperial brasileira estiveram sempre presentes na Marmota. Em 1854 o periódico, por exemplo, veio acompanhado de uma "Lira"; uma página extra com versos de Paula Brito - emoldurados em uma bela apresentação gráfica - dedicados à imperatriz, uma vez que o domingo anterior havia sido dia de Santa Tereza de Jesus, "nome de sua majestade, a senhora D. Tereza Maria Cristina"109. Pouco depois, foi a vez de o imperador ser homenageado, com um soneto, agora pelo dia de São Pedro de Alcântara - um dos santos de devoção da Casa de Bragança e que servira de inspiração para o nome de Pedro II e de seu pai ${ }^{110}$.

Além de artigos explicitamente dedicados aos soberanos, a Marmota também se valia de outros artifícios para fazer seus leitores lembrarem-se de seus governantes. Essa foi a intenção da matéria "O Nome Pedro ou Trezentos e Sessenta e Cinco Dias", uma espécie de levantamento, para cada dia do ano, de um marco histórico envolvendo alguma personalidade célebre chamada Pedro. Em um artigo, por exemplo, foram abordados três dias do mês de janeiro; no dia 9, em 1579, nasceu Pedro Tallizy Girão, duque de Ossuna; dia 10, em 1709, morreu Pedro Hotton, reconhecido botânico holandês; e em 11 de janeiro de 1592 morreu D. Pedro de Figueiró, cônego e doutor pela Universidade de Coimbra ${ }^{111}$. Essa matéria estendeu-se por diversos exemplares do periódico, até completar a meta dos 365 dias do ano.

108. Idem, n. 993 , p. 1,8 out. 1858.

109. Marmota Fluminense, n. 514, 17 out. 1854.

110. Lilia Moritz Schwarcz, As Barbas do Imperador, p. 45.

111. Marmota Fluminense, n. 539, 12 jan. 1855, p. 1. 


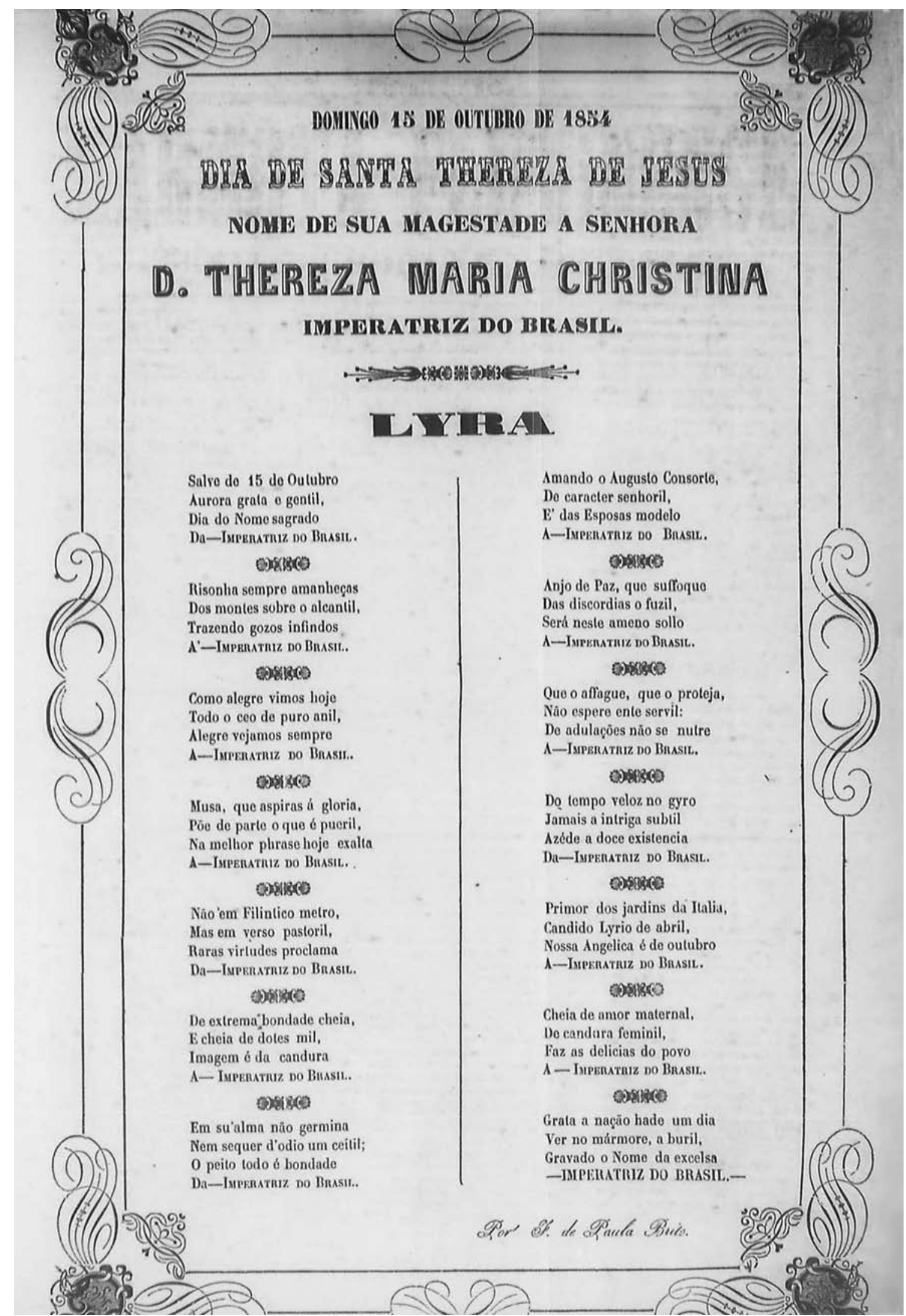

Figura 42. Lira oferecida por Francisco de Paula Brito à imperatriz na Marmota Fluminense (17 out. 1854). 
Figura 43. Soneto de Paula Brito desejando melhoras à saúde do imperador (6 jun. 1854).

Desde o primeiro número de $A$ Marmota na Corte, já era possível perceber essa característica da publicação, sua reverência à figura do imperador. No texto "Vista Séria - Pequeno Sinal de Gratidão do Súdito Reconhecido ao Monarca Obsequioso", Próspero Diniz informa que fora ao palácio de São Cristóvão “[...] com o fim de beijar a mão ao nosso Imperador, e participar-lhe que ia dar princípio a esta folha, para desta forma significar-lhe quanto desejo prestar a devida consideração à sua digna pessoa [...]"112. Prossegue contando que “[...] pedindo ao Imperador a mão para beijar-lha, prestou-se a dar-me esta honra com a afabilidade de um pai, e modéstia de um verdadeiro filantropo [...]". A narrativa continua com animados elogios, tanto destinados a Pedro II como aos

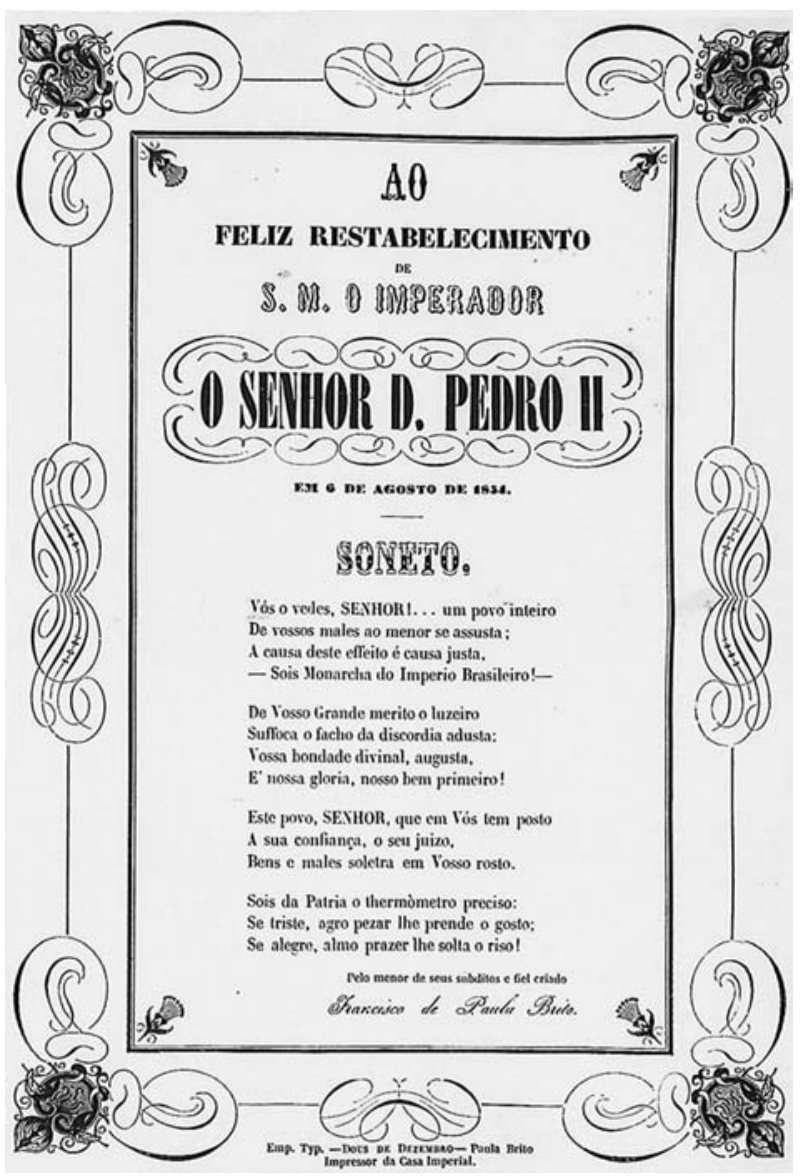
funcionários do palácio. O redator demonstra, por meio de suas colocações, grande preocupação acerca do juízo que o monarca faria de sua folha e busca uma forma de descrevêla como adequada sob todos os aspectos.

Poucos meses após o lançamento da Marmota, estampava sua primeira página um “Tributo de Saudade pela Mui Sentida Morte do Príncipe Imperial, o Senhor D. Pedro Afonso" assinado por Constantino José Gomes de Souza ${ }^{113}$. Embora essa matéria tratasse especificamente de um falecimento dentro da família real, a Marmota também costumava dar ênfase às mortes de personalidades de algum modo ligadas ao monarca. Foi o caso de José Clemente Pereira. Em 1854 a folha reproduziu um decreto do Ministério do Império no qual Pedro II, "querendo dar um testemunho pessoal do apreço" pelos serviços de Pereira, mandou que fizessem uma estátua dele, que ficaria na Santa Casa de Misericórdia, onde ele havia sido provedor. O português José

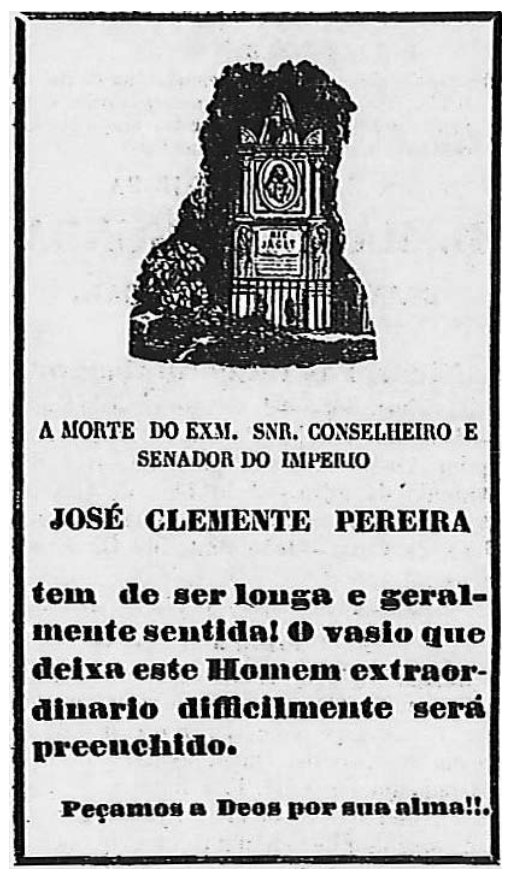

Figura 44. Nota pelo falecimento de José Clemente Pereira.

112. A Marmota na Corte, n. 1, p. 2, 7 set. 1849.

113. A Marmota na Corte, n. 37, 18 jan. 1850. 
Clemente Pereira era politicamente atuante desde a época de Pedro I, quando entregou ao príncipe regente uma lista com oito mil assinaturas, pedindo que não deixasse o país ${ }^{114}$.

Um ponto muito importante a ser destacado nesse quadro de encômio ao imperador é que no ano de lançamento da Marmota inicia-se um certo tipo de matéria que se tornará tradição no jornal: as homenagens ao aniversário de D. Pedro II. O dia dois de dezembro era feriado oficial no Império, de modo que a memória do imperador, celebrada pela lembrança de seu aniversário, era festejada pelo país afora ${ }^{115}$. Nesse dia, o imperador recebia os cumprimentos em pessoa na corte; e, nas províncias os presidentes, representantes da coroa, cumpriam esse papel.

Aparentemente o natalício do imperador destacava-se das demais datas cívicas comemoradas no Brasil, que podiam ser resumidas em: Ano-Bom em 1 de janeiro, juramento da Constituição do Império em 25 de março, ascensão de Pedro II ao trono em 7 de abril, abertura da Assembléia Nacional em 3 de maio, proclamação da Independência em 7 de setembro e aniversário do imperador em 2 de dezembro ${ }^{116}$.

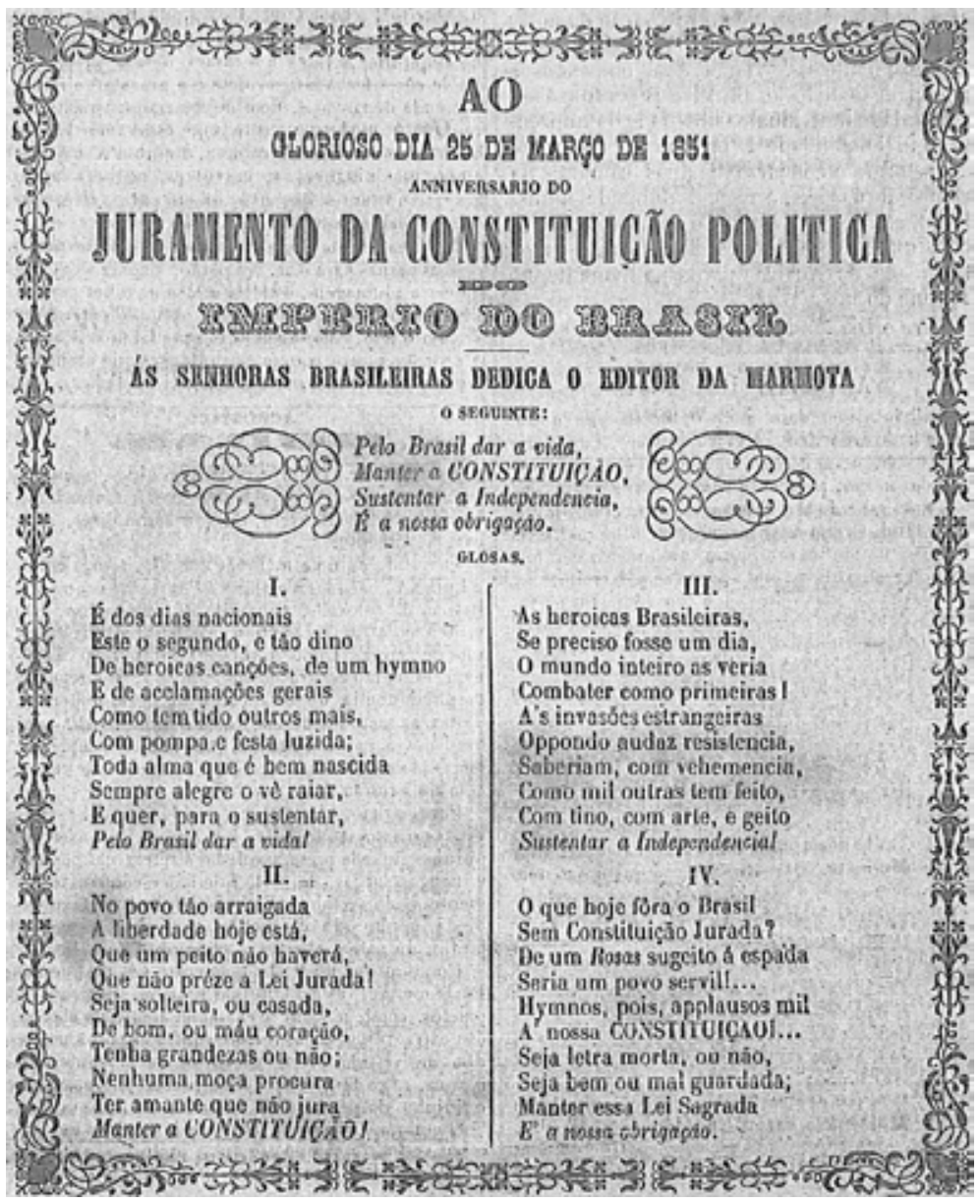

Figura 45. Glosa de Paula Brito comemorando o aniversário da Constituição do Brasil (Marmota na Corte, 25 mar. 1851).

114. Leslie Bethell (org.), História da América Latina, vol. III, pp. 216-217.

115. Daniel P. Kidder apud Lilia Moritz Schwarcz, As Barbas do Imperador, p. 255.

116. Idem, ib., p. 254. 
O texto de 1849 da Marmota sobre "O Dia Dous de Dezembro" foi redigido por Próspero Diniz, que narra sua participação nas as festividades do dia na corte: toque de cornetas pela manhã para lembrança da data, missa em solenidade ao imperador, parada com desfile da Guarda Nacional e da cavalaria, os cumprimentos que sua majestade distribuiu no largo do paço e o evento no teatro naquela mesma noite ${ }^{117}$. No ano seguinte, as honras da Marmota ao imperador foram prestadas por Paula Brito, que também comemorava seu aniversário em 2 de dezembro, e ofereceu a D. Pedro II um soneto, cujos últimos versos são:

\author{
Mas que tem que invejar de Tito a fama, \\ Pelo Renome que deixou no mundo \\ Quem do Rei justo as qualidades ama?.. \\ O Brasil, não; (em fatos eu me fundo); \\ Pois, mais jovem que Tito, já proclama \\ Novo Tito o Imortal - Pedro SEgundo ${ }^{118}$ !
}

A Marmota na Corte de 2 dezembro de 1851, mais uma vez, trouxe um texto de Próspero Diniz enaltecendo as qualidades do monarca e um trecho do poema Independência do Brasil, de Teixiera e Souza, como protesto de veneração e respeito ao governante em seu aniversário. Em 1852, além de um soneto não assinado, há na primeira página um artigo muito elogioso dedicado ao imperador, igualmente não assinado, que busca apresentar o monarca, também, como cidadão, marido, pai e pessoa religiosa:

Não é só porque o Brasil memore neste Magnífico Dia o feliz Aniversário de seu Augusto Monarca, não; mas é porque soleniza os Anos do Rei Magnífico, e do Cidadão Honrado, do Rei justiceiro, e do Homem piedoso; do Soberano religioso, e do Cidadão filósofo; do Monarca modelo, e do Homem esposo exemplar, Pai amante, Cidadão virtuoso e prestante, em cujo coração arde, com inextinguível chama, o santo fogo do amor da Pátria, o excelso raio do amor da Glória, a exímia luz do Talento que O constituem Protetor das Letras, das Ciências, das Artes e da Indústria ${ }^{119}$.

Em 2 de dezembro de 1853, novamente viu-se na primeira página da Marmota Fluminense um artigo encomiástico devotado ao monarca, seguido por uma ode composta por Teixeira e Sousa e por um soneto de autoria de Paula Brito dedicado ao soberano. No ano posterior, as homenagens foram impressas no dia primeiro do mês, mas do mesmo modo não faltaram sonetos e palavras repletas de veneração nas linhas oferecidas a D. Pedro II.

Em 1855, a primeira página da Marmota Fluminense foi totalmente devotada ao aniversário do imperador. Na coluna "A Marmota" o jovem Machado de Assis louvava D. Pedro II em seus versos, declarando-se, antes de suas iniciais, "seu reverente súdito", como se percebe pela transcrição:

117. A Marmota na Corte, n. 26, p. 1, 4 dez. 1849.

118. Idem, n. 115, p. 1, 3 dez. 1850.

119. Idem, n. 319, p. 1, 2 dez. 1851. 
Soneto a S. M. o Imperador, o senhor

D. Pedro II

Nesse trono, Senhor, que foi erguido

Por um povo já livre, e sustentado

Por ti, que alimentando as leis, o estado

Hás na História teu Nome engrandecido;

Nesse trono, Senhor, onde esculpido

Tem a destra do Eterno um nome amado,

Vês nascer este dia abrilhantado

Sorrindo a ti, Monarca esclarecido!

Eu te saúdo neste dia imenso!

Da Clemência, Justiça e sã Verdade

Queimando ás piras perfumoso incenso!

Elevado aos umbrais da imensidade

Terás fama, respeito, e amor intenso,

Um Nome transmitido á Eternidade!

Rio de Janeiro, 2 de dezembro de 1855

Pelo seu reverente súdito

J. M. M. d’Assis ${ }^{120}$

Ao lado, encontra-se o texto, não menos elogioso, de Paula Brito intitulado "Dous de Dezembro". Em seu primeiro parágrafo lê-se:

É este um Dia, cuja radiante aurora todos os Brasileiros deveriam saudar cheios de júbilo, e de um verdadeiro entusiasmo; porque depois do Dia 7 de Setembro de 1822, e do dia 25 de Março de $1824^{121}$, nenhum outro como ele deve ser desejado, porque, como ele, nenhum outro faz a gloria do Brasil, o orgulho dos Brasileiros!

Continuando a enaltecer as virtudes de seu monarca, o tipógrafo chega a repreender os fluminenses que se deixam tão pouco impressionar pela nobre figura que entre eles vive. E condena a indiferença com que os brasileiros em geral tratam “aqueles Dias da Pátria” - 7 de setembro e 25 de março - e "este Dia do Povo" - natalício de D. Pedro -, demonstrando um certo "vício" de sua educação.

120. Marmota Fluminense, n. 654, 2 dez. 1855. Este exemplar saiu em um domingo, que não costumava ser dia de circulação do jornal.

121. A primeira data refere-se ao aniversário da proclamação da Independência no Brasil. E em março de 1824 foi outorgada por Pedro I a primeira Constituição brasileira. 
Em 1857, a homenagem ao imperador circulou com um certo atraso, em 18 de dezembro, e oferecia apenas um soneto. Em 14 de dezembro de 1858, na coluna "A Marmota", a matéria "A Graça do Dia Dous" podia fazer pensar que se tratava de mais um texto devotado ao imperador. No entanto, o teor desse artigo era um tanto distinto. Tratava-se de uma crítica ao que tinha acontecido nas comemorações cívicas do natalício de Pedro II. Segundo a Marmota, algumas pessoas foram recompensadas com quantias em dinheiro e medalhas, sem serem merecedoras de semelhante reconhecimento, pelo auxílio às vítimas da epidemia de cólera de 1855 - que também ocorreu demasiadamente tarde, na perspectiva o jornal.

No ano de 1859, a comemoração ao natalício do monarca na folha resumiu-se a uma composição "copiada", como anunciado na primeira página do jornal: "Da Marmota na Bahia copiamos o seguinte Padre Nosso a S. M. o Imperador do Brasil" ${ }^{122}$. No ano seguinte, dois números da Marmota tiveram matérias dedicadas à data, 1.218 e 1.219. No primeiro, na segunda página, foi publicada uma alegoria de Francisco de Paula Brito, “A União do Império", devotada ao aniversário do monarca. E no exemplar 1.219 dois sonetos foram oferecidos ao real aniversariante, um de Paula Brito, outro assinado por R. Nesse mesmo número, Paula Brito publicou os seus "Versos a Mim Mesmo", nos quais falava sobre seu aniversário, uma dia de gala na corte graças à coincidência com o natalício de Pedro II, mas, com certo teor melancólico, constatava que do alto de seus 52 anos, "não tenho cousa que preste; / 'abro a mão, não acho nada'”.

Em 1861 realmente não encontrou Pedro II qualquer menção ao seu dia de nascimento na Marmota, isso porque no primeiro dia de dezembro desse ano, faleceu Antonio Gonçalves Teixeira e Sousa. Desse modo, Paula Brito dedicou uma matéria à morte do querido amigo na primeira página do dia 6 de dezembro. E, pouco tempo depois, o próprio tipógrafo faleceu, no dia 15 do mesmo mês.

Mesmo sendo possível notar que a partir de 1857 houve certa parcimônia em relação aos tributos prestados ao imperador no jornal de Paula Brito, os exemplos anteriores ratificam a idéia de que, evitando temas polêmicos do período, como a escravidão ou discussões políticas mais profundas, a Marmota buscava oferecer sempre apoio ao imperador e ao regime monárquico.

Um elemento interessante a se considerar neste contexto é a criação da Empresa Dous de Dezembro por Paula Brito, que, buscando verbas para expandir seu negócio, decidiu iniciar uma sociedade por ações. Segundo Eunice Ribeiro Gondim ${ }^{123}$ e conforme anúncio do Almanaque Laemmert ${ }^{124}$, Brito era seu principal proprietário, embora houvesse outros acionistas, entre eles, "Suas Majestades Imperiais" que são descritos como "protetores e primeiros acionistas".

O tipógrafo registrou, em uma de suas poesias publicada na Marmota, a relação de proteção entre sua empresa e os soberanos:

Das moças eu nunca tive

Motivo para queixar-me,

122. A Marmota, n. 1.114, p. 1, 6 dez. 1859.

123. Eunice Ribeiro Gondim, Vida e Obra de Paula Brito, p. 19.

124. Almanaque Laemmert, p. 269, 1851. 
Porque também sei com elas

Delicado comportar-me.

Eu sou, talvez, o Empresário

Que mais Damas Brasileiras

Conta Acionistas, bem como

Conta também Estrangeiras.

Espero que a minha Empresa

Prospere sempre feliz,

Tendo por Guarda O - Imperante,

E a Virtuosa - Imperatriz ${ }^{125}$.

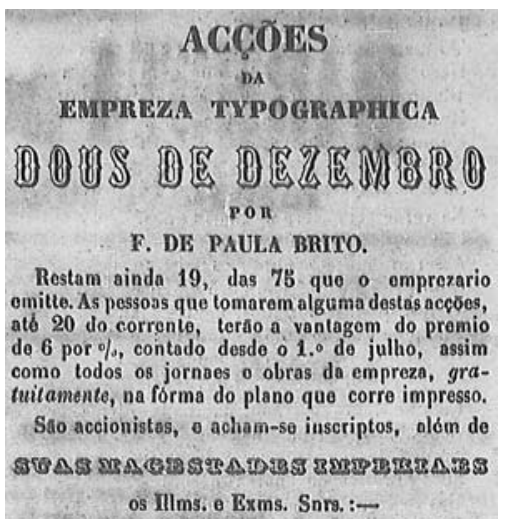

Figura 46. Paula Brito anuncia as ações da Empresa Tipográfica Dous de Dezembro que ainda estão disponíveis para a venda ( 2 dez. 1851).

O nome da empresa, que permaneceu ativa entre 1850 e 1857, é uma alusão à coincidência das datas de nascimento do tipógrafo e de D. Pedro II. A Marmota, então, trazia em seu cabeçalho: "Publica-se, às Terças e Sextas feiras, na Empresa Tip. - Dous de Dezembro - de Paula Brito, impressor da Casa Imperial [...]"126. Sobre essa informação de Paula Brito ser impressor da Casa de Bragança, Moreira de Azevedo afirma: "Pelos seus serviços o nomeará S. M. o Imperador seu criado particular e impressor de sua imperial casa ${ }^{127 ”}$. Imagina-se que tanto o fato de ter sido nomeado impressor da Casa Imperial como o da sociedade de Suas Majestades na empresa tipográfica envolvem uma espécie de relação de mecenato entre Pedro II e Paula Brito. A partir dessa idéia, é viável imaginar a Marmota, também, como uma forma de veículo do poder, buscando sempre legitimar os discursos estabelecidos pelo Segundo Reinado, e, ao mesmo tempo, evitando quaisquer temáticas que pudessem ensejar debates contra eles.

A condição de "patrocinador" e incentivador da cultura nacional começa a manifestar-se em Pedro II a partir dos anos de 1850, na tentativa de formular uma imagem para a nação - tipicamente brasileira e sem qualquer vínculo com a ex-metrópole - e de legitimar essa nobreza "tropical”. Uma das principais ferramentas utilizada na busca da autonomia cultural foi o Instituto Histórico e Geográfico Brasileiro (IHGB), que abrigou toda a geração romântica a partir de $1840^{128}$, mesma época em que

125. Marmota Fluminense, n. 440, p. 1, 31 jan. 1854.

126. Talvez a diminuição da intensidade dos elogios ao imperador, observada a partir de 1857 no jornal, tenha a ver com a liquidação da empresa. Depois de decretada sua falência, Paula Brito viu seus negócios recuarem de forma significativa.

127. Francisco de Paula Brito, Poesias de Francisco de Paula Brito, p. XX.

128. Conviveram ali, em uma relação estreita com Pedro II, Domingos José de Gonçalves Magalhães, Manuel de Araújo Porto-Alegre, Joaquim Norberto de Sousa e Silva, Joaquim Manuel de Macedo, Gonçalves Dias e Francisco 
o imperador tornou-se freqüentador assíduo da instituição. Nesse sentido, Lilia Moritz Schwarcz afirma:

Na verdade, é com a entrada de d. Pedro II no IHGB e seu mecenato que o romantismo brasileiro se transforma em projeto oficial, em "verdadeiro nacionalismo", e como tal passa a inventariar o que deveriam ser as "originalidades locais".

[...] Era d. Pedro II quem patrocinava, particularmente, projetos de pesquisa de documentos relevantes à história do Brasil, no país e no estrangeiro. [...] D. Pedro financiou ainda profissionais de diversas áreas, como advogados, agrônomos, arquitetos, um aviador, professores de escolas primárias e secundárias, engenheiros farmacêuticos, médicos, militares, músicos, padres e muitos pintores ${ }^{129}$.

Percebe-se que além de reforçar a figura de Sua Majestade, a Marmota acabou por ser parte do "projeto oficial" de nacionalização da cultura brasileira, por meio da divulgação de obras e autores românticos, especialmente aqueles com os quais Pedro II mantinha relações no IHGB. Mais um motivo para crê-la como meio de comunicação a serviço dos interesses do imperador.

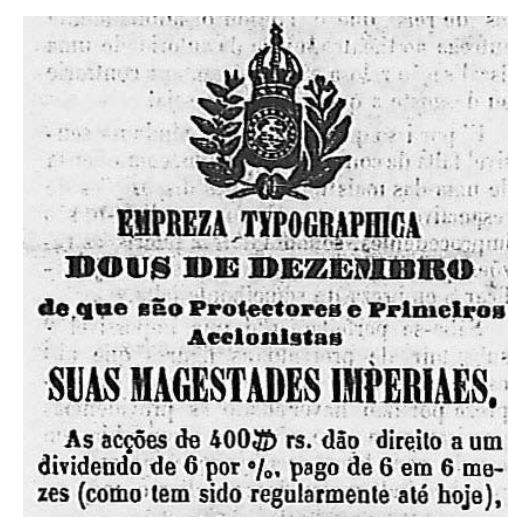

Figura 47. Marca da Empresa Tipográfica Dous de Dezembro (Marmota Fluminense, 15 set. 1854).

Adolfo Vernhagen. Com exceção deste último, os demais foram colaboradores da Marmota e freqüentadores da loja de Paula Brito.

129. Lilia Moritz Schwarcz, As Barbas do Imperador, p. 131. 



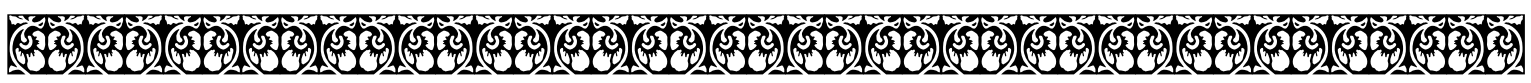 A Figura de Francisco de Paula Brito

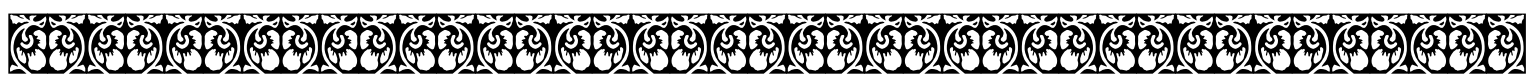

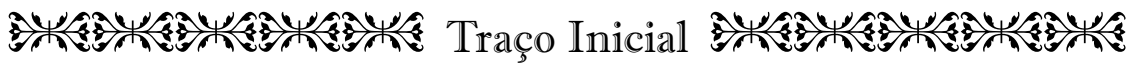

"Paula Brito foi o primeiro editor digno desse nome que houve entre nós ${ }^{1 "}$. Essas palavras de Machado de Assis tornaram-se parte importante do discurso criado sobre o tipógrafo carioca Francisco de Paula Brito (1809-1861).

As diversas falas que fazem parte da construção dessa figura - atualmente presente em textos sobre história do livro, da literatura e da cultura brasileira -, começaram a ser disseminadas logo após sua morte, em dezembro de 1861. Naquele mesmo mês, em sua coluna no Diário do Rio de Janeiro, Machado prestou uma homenagem ao amigo que acabara de falecer e, em sua crônica, registra alguns traços de sua personalidade:

Começou como impressor, como impressor morreu. Nesta modesta posição tinha em roda de si todas as simpatias.

Paula Brito foi um exemplo raro e bom. Tinha fé nas suas crenças políticas, acreditava sinceramente nos resultados da aplicação delas; tolerante, não fazia injustiça a seus adversários; sincero, nunca transigiu com eles.

Era também amigo, era sobretudo amigo. Amava a mocidade, porque sabia que ela é a esperança da pátria, e, porque a amava, estendia-lhe quanto podia a sua proteção.

Em vez de morrer, deixando uma fortuna, que o podia, morreu pobre como vivera, graças ao largo emprego que dava às suas rendas, e ao sentimento generoso que o levava na divisão do que auferia de seu trabalho.

Nestes tempos, de egoísmo e cálculo, deve-se chorar a perda de homens que, como Paula Brito, sobressaem na massa comum dos homens ${ }^{2}$.

Nessa descrição machadiana de Paula Brito, surgem elementos que serão exaustivamente repetidos, como o temperamento amigável e tolerante, o apoio que oferecia aos jovens, a escassez de recursos financeiros e o espírito generoso. Do mesmo modo, muito do que se falou posteriormente sobre o tipógrafo, foi graças à sua relação tão próxima com o autor de Dom Casmurro.

1. Diário do Rio de Janeiro, 3 jan.1865, em Machado de Assis, Crônicas, vol. 2, p. 264.

2. Idem, 24 dez. 1861, em Machado de Assis, Crônicas, vol. 1, pp. 95-96. 


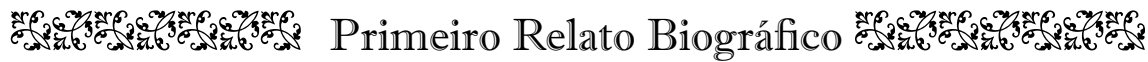

Embora as impressões de Machado de Assis sejam sempre lembradas e verdadeiramente relevantes - tanto pela proximidade existente entre ambos, como pelo valor literário de seus escritos - Manuel Duarte Moreira de Azevedo foi quem primeiro se prestou, de fato, ao papel de biógrafo de Paula Brito. Foi de sua autoria o artigo "Biografia do Sr. Francisco de Paula Brito", que saiu na seção "Publicações a Pedido" do Correio Mercantil, em 1862 (números dos dias 28 de fevereiro, 2 e 3 de março). Esse mesmo texto, posteriormente, foi incorporado às páginas iniciais de Poesias de Francisco de Paula Brito, edição póstuma organizada pelo próprio Moreira de Azevedo. O volume, editado em 1863 pela tipografia de Paula Brito (dirigida, então, por sua viúva), contava com 37 páginas pré-textuais e 208 de miolo. As primeiras eram constituídas por "Prefácio" e "Biografia”. As poesias foram divididas da seguinte maneira: "I - O Livrinho das Moças", "II - Poesias Diversas" e "III - Anônimas".

Logo no início da sucinta biografia, o autor comenta sobre os vultos da história que não tiveram sua genialidade reconhecida em vida, a exemplo de Homero e Camões:

É uma triste realidade: o dia da glória começa na noite da morte.

Só depois que a vida abandona o corpo, e que a alma transpõe os umbrais da eternidade, nasce para o finado o renome e a glória terrestre; é do túmulo que se ergue o anjo, que deve lembrar às idades futuras o nome do morto; é sobre o túmulo que se coloca a palma do martírio ${ }^{3}$.

Para ele, Paula Brito não foi exceção. Moreira de Azevedo oferece algumas informações sobre as origens de seu biografado, como o nascimento em 2 de dezembro de 1809, no Rio de Janeiro, em

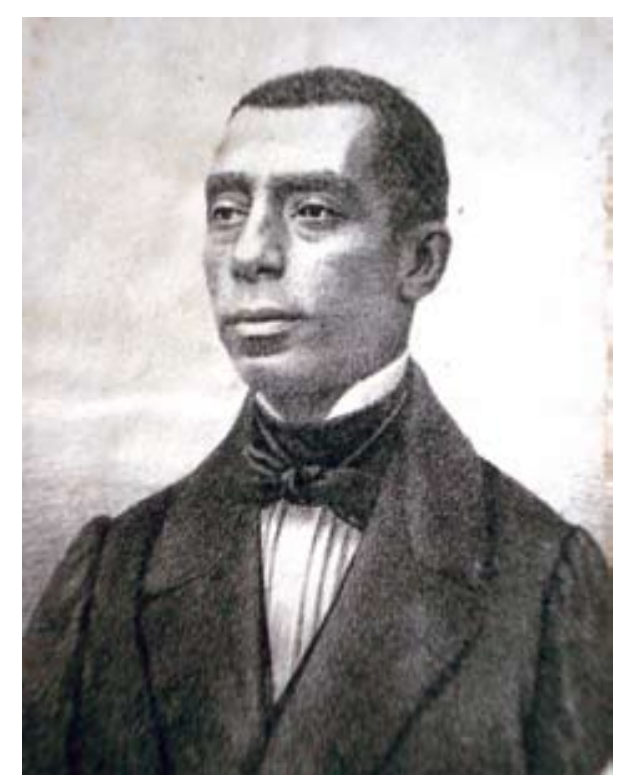

uma casa modesta. Ainda criança, em 1815, Brito mudou-se com a família para o interior do estado, tendo sido, então, alfabetizado por uma irmã mais velha. Com cerca de quinze anos, ele teria voltado para a capital do Império com seu avô materno.

A peculiar atenção dispensada por Moreira de Azevedo, em sua biografia, a Martinho Pereira de Brito, o avô, é interessante. Enquanto há poucas palavras para os pais de Paula Brito - fala-se apenas que o pai, Antunes Duarte, foi carpinteiro e a mãe, dona Maria Joaquina da Conceição, dedicava-se à família -, o avô é qualificado como

Figura 1. Gravura de Paula Brito constante nas páginas iniciais de sua obra póstuma.

3. Moreira de Azevedo, "Biografia", em Poesias de Francisco de Paula Brito, p. VII. 
um artista, um dos primeiros "ourives de martelo" da época, que esculpia lampadários de prata para igrejas ${ }^{4}$. Além disso, o autor informa que Martinho comandou o $4^{\circ}$ Regimento dos Milicianos, conhecido também como "regimento dos pardos", tendo alcançado o posto de sargento-mor. Esse modo de apresentação do avô de Paula Brito parece buscar subsídios para legitimar a posição em que o tipógrafo é enquadrado, como artista inserido no movimento cultural de seu tempo, neto de um homem que também o fora.

Em relação ao desenvolvimento profissional de Paula Brito, há indícios de que ele teria trabalhado em uma botica antes de se tornar aprendiz na Tipografia Imperial e Nacional, que foi, como se sabe, sucessora da Impressão Régia. Pouco depois, teria sido empregado na tipografia de René Ogier, passando posteriormente para o estabelecimento de Pierre Plancher, fundador e editor do Jornal do Commercio. Na tipografia de Plancher, Paula Brito teve a oportunidade de atuar em diversas funções, como compositor, diretor de prensas, redator e até tradutor.

Moreira de Azevedo afirma que em 1830 foi celebrado o casamento de Paula Brito e que, no ano seguinte, ele adquiriu de seu primo uma loja - oficina de encadernação onde também se comercializavam livros - e lá instalou sua tipografia. Ainda em 1831, o tipógrafo teria começado a oferecer seus serviços de impressão a diversas folhas e salienta-se: "de seus prelos saíam os periódicos que deviam acalmar a cólera das turbas; eram de sua oficina que partiam as idéias de ordem e de moderação"s. Essa colocação sobre publicação de idéias moderadas está relacionada ao período em que Paula Brito começou a atuar no mercado gráfico, o início da Regência, marcado, como se sabe, por inúmeras revoltas provinciais.

Segundo Morel e Barros, o intervalo entre 1831 e 1833 foi caracterizado pelo crescimento da imprensa periódica no Rio de Janeiro ${ }^{6}$. As crises política e de abastecimento, que culminaram com a abdicação de D.

4. Moreira de Azevedo, op. cit., p. X.

5. Idem, ib., p. XII.

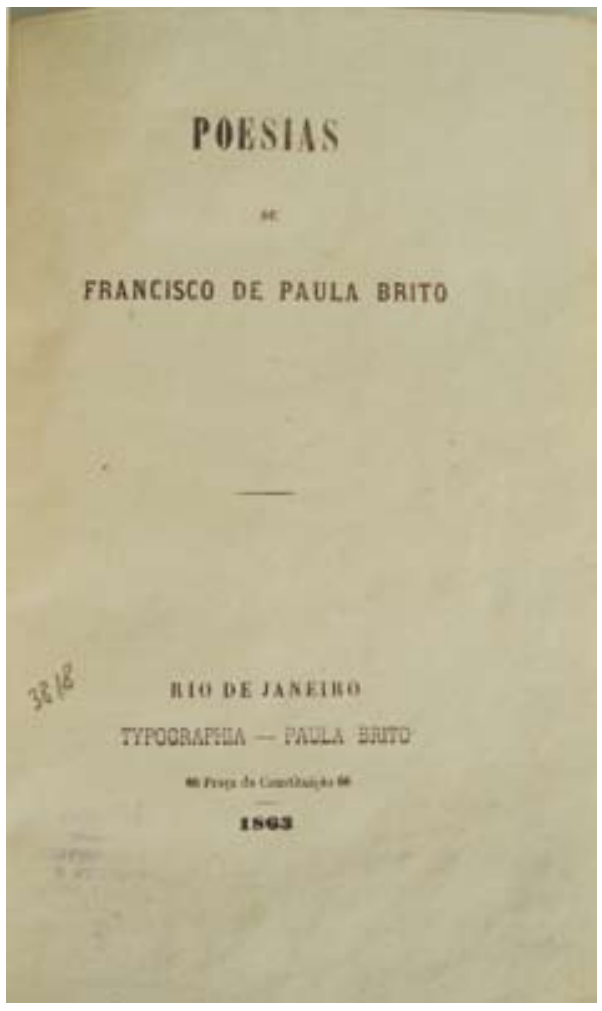

Figura 2. Frontispício de Poesias de Francisco de Paula Brito.

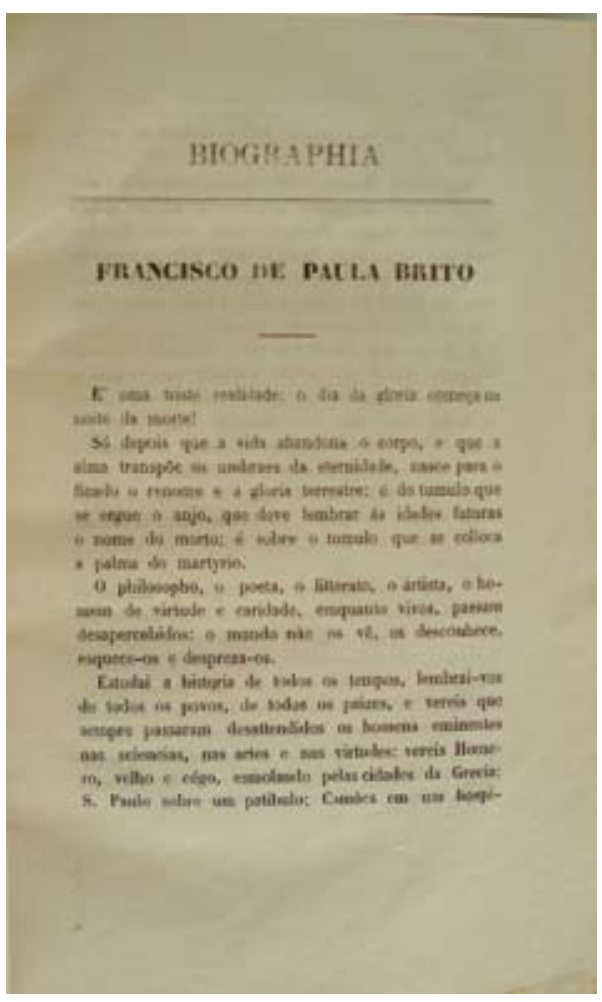

Figura 3. Página de abertura da biografia elaborada por Moreira de Azevedo.

6. Marco Morel e Mariana M. Barros, Palavra, Imagem e Poder, p. 29. 
Pedro I, fomentaram também agitações civis e militares nas ruas da capital do Império, que, por sua vez, redundaram em descrédito ainda maior ao poder monárquico (que já se encontrava em situação negativa em virtude do trono vazio), o que gerou uma explosão da palavra pública - com jornais, panfletos e toda sorte de pasquins.

Um dos pontos que Manuel Duarte Moreira de Azevedo busca resgatar é a participação política de Paula Brito nesse quadro tão conturbado, como fruto de seus esforços para superar uma condição sociocultural relativamente "inferior" quando comparada à de seus "adversários":

Ele, o tipógrafo-editor, dedicado ao trabalho, à pátria e aos amigos não descansava nunca. Enquanto arriscava a vida, publicando um jornal nesses dias de luta e de anarquia, procurava estudar, aprender consigo, para poder também lutar na imprensa com os seus adversários: as bagas do suor, que banhavam o rosto do artista, vinham cair nas páginas do livro do homem estudioso. E por si se fez escritor e chegou a ser poeta....

Mais tarde, o talentoso patriota Evaristo Ferreira da Veiga penetrava no interior de uma oficina, e entusiasmado abraçava um moço que fizera um belo hino à liberdade. Era Paula Brito o moço inteligente, o jovem patriota, que recebia essa prova de consideração de um dos homens mais distintos desses tempos.

Paula Brito, que não recebera instrução, que não conhecera mestres, conseguiu pelo seu trabalho, pela sua vontade, pela sua inteligência, alcançar lugar notável, não só entre os artistas, senão entre os políticos de sua época. Aquele, que começara como simples operário, chegou a ser artista hábil, patriota distinto, jornalista inteligente ${ }^{7}$.

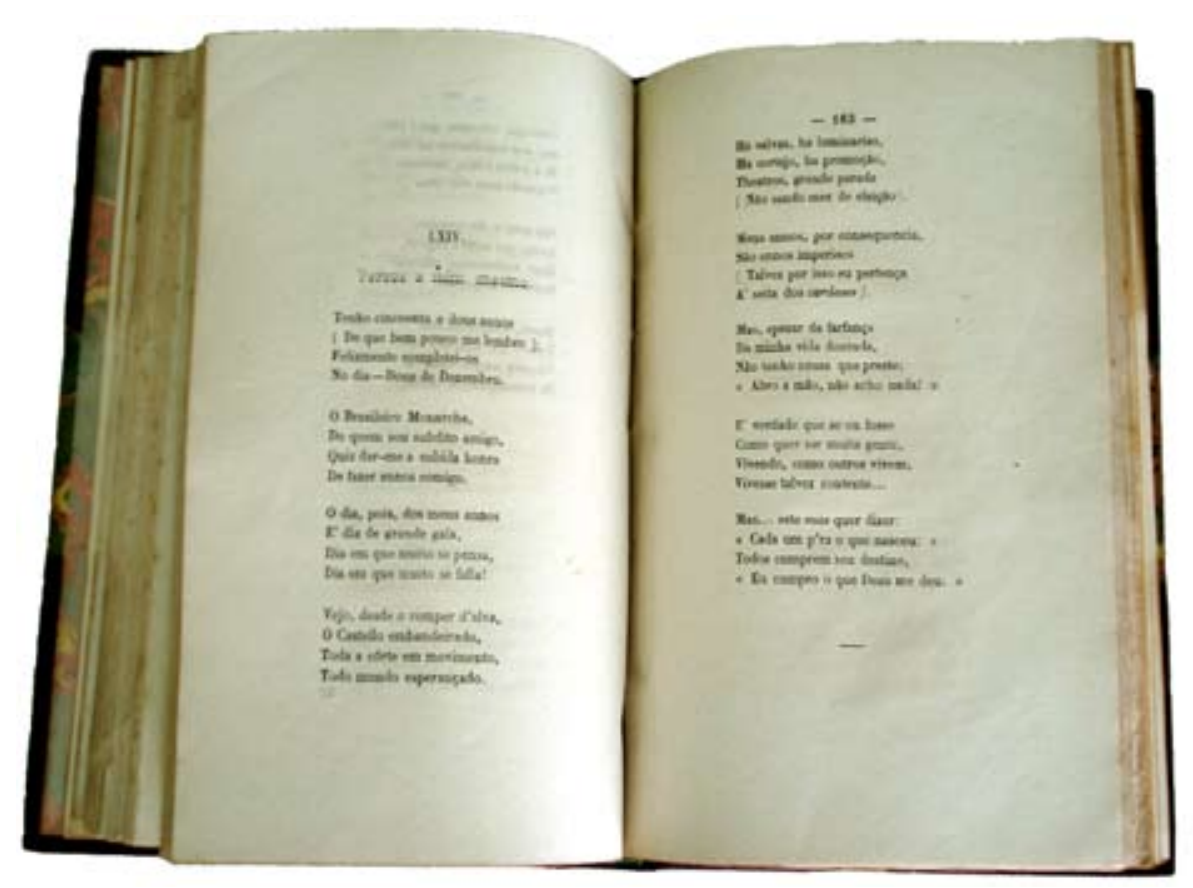

Figura 4. "Versos a Mim Mesmo" de Poesias de Francisco de Paula Brito.

7. Moreira de Azevedo, op. cit., p. XIII. 
Mais uma vez, o biógrafo busca valorizar seu objeto de estudo. Em sua perspectiva, Paula Brito teria acesso não apenas à elite cultural de seu tempo, mas também à elite política. Ele não era mais um simples tipógrafo, um operário, por esforço próprio teria agregado para si epítetos como: poeta, escritor, artista e jornalista.

Moreira de Azevedo também destaca que a bravura de Paula Brito não envolvia apenas a impressão de periódicos de cunho político em sua oficina. Nesse mesmo espaço, o tipógrafo oferecia aos amigos e freqüentadores da loja um local para encontro e debate de idéias, mesmo sendo uma prática proibida pelas autoridades governamentais da época.

Como se sabe, o Período Regencial foi um dos mais agitados da história política do país e, igualmente, um dos mais importantes. Naqueles anos, esteve em jogo a unidade territorial do país, de modo que o foco do debate político recaiu sobre temas como centralização ou descentralização do poder, o grau de autonomia das províncias e a organização das Forças Armadas. Foi um momento tão intricado da história brasileira que mesmo entre grupos e classes dominantes, não havia consenso sobre quais arranjos institucionais seriam mais convenientes a seus interesses. Ademais, não havia sequer clareza sobre qual seria o papel do Estado como organizador dos objetivos pretendidos por grupos dominantes, o que resultou, em determinados momentos, no sacrifício de interesses específicos, oriundos de determinado setor social ${ }^{8}$.

Durante a Regência Trina Permanente ${ }^{9}$, em 5 de dezembro de 1833, a agitação política no país teria atingido um nível crítico, em virtude do debate sobre a reforma constitucional e o banimento oficial de Pedro I, que já tinha deixado o trono e o país. Moreira de Azevedo relata que diversas tipografias foram destruídas e saqueadas no Rio de Janeiro - menos a de Paula Brito (por esquecimento ou consideração, não se sabe). E afirma que no dia seguinte saíram de suas oficinas folhetos contra as injustiças e arbitrariedades do povo que havia depredado o patrimônio privado.

"O modesto impressor chegou a ser pelo seu trabalho, perseverança e estudo, o mais importante editor do país; aquele, que começara como um simples prelo chegou a montar o nosso mais belo estabelecimento tipográfico" ${ }^{10}$, novamente, a tentativa é elaborar a imagem de Brito como homem que se fez por si próprio, que partiu das camadas mais baixas da sociedade e alcançou as mais elevadas. Esse argumento funda uma das facetas mais características do discurso sobre Francisco de Paula Brito que estava por vir.

Pretendendo louvar o tipógrafo por meio da conceituação de sua oficina, registra o autor:

Nenhum estabelecimento no Rio de Janeiro era mais conhecido do que a tipografia de Paula Brito na praça da Constituição n. 64. Esse estabelecimento se tornou popular, como o seu dono. Aí iam todos, ou para comprar algum livro que não havia em outra loja, ou para fazer alguma impressão rápida e importante, ou para fazer imprimir algum trabalho que não podia ser feito em outra parte por falta de meios $[\ldots]^{11}$.

8. Boris Fausto, História do Brasil, pp. 161-162.

9. Ativa entre 1831 e 1834, foi composta pelo deputado José da Costa Carvalho, deputado João Bráulio Muniz e pelo brigadeiro Francisco de Lima e Silva.

10. Moreira de Azevedo, op. cit., p. XVIII.

11. Idem, ib., p. XIX. 
Emp, Typ.- Dots be Dezexpno - de Paula Brito Impressor da Casa Imperial.

Figura 5. Rodapé da última página da Marmota Fluminense onde se lê a chancela do tipógrafo: "Impressor da Casa Imperial".
Talvez a idéia de que a loja de Paula Brito era um dos estabelecimentos mais conhecidos do Rio de Janeiro se aplique mais precisamente ao universo das livrarias e das tipografias da época, mas não deixa de ser um indício de que ela ocupava certo lugar de destaque no comércio carioca. Moreira de Azevedo assevera, ainda, que o imperador, D. Pedro II, nomeou Francisco de Paula Brito o impressor da Casa Imperial, e que este, mesmo sendo um fiel súdito, nunca havia usado essa chancela nas portas de sua loja ${ }^{12}$. Trata-se, realmente, de uma forma de apresentar o tipógrafo como indivíduo distante de ambições como ascensão social e reconhecimento público. Entretanto, a chancela "Impressor da Casa Imperial" constou tanto no cabeçalho do jornal Marmota Fluminense, pertencente a Paula Brito, como ao final da última página da publicação.

Sobre os jornais dirigidos por Paula Brito, menciona-se que em 1836 ele teria criado A Mulher do Simplício ou A Fluminense Exaltada, que circulou indeterminadamente e teria durado mais de oito anos. No entanto, atualmente, sabe-se que a folha foi criada em 1832 e há registros de sua circulação ainda em $1846^{13}$. Moreira de Azevedo avalia que: "muito apreciada foi essa publicação no seu tempo, e ainda hoje deve ser considerada como uma preciosidade, porque é o único periódico daquela quadra que trata das modas, dos divertimentos de então, narrando em verso os acontecimentos que se davam" ${ }^{14}$.

Dando continuidade à narração, o autor informa sobre outro periódico pertencente a Paula Brito, A Marmota na Corte, criado em 1849. Seu primeiro redator foi Próspero Diniz. Em 1852, o próprio Brito passou a ser responsável pela redação da folha, que foi renomeada como Marmota Fluminense. Em 1857 o título mudou mais uma vez, para A Marmota, e perdurou até seu final, em 1861.

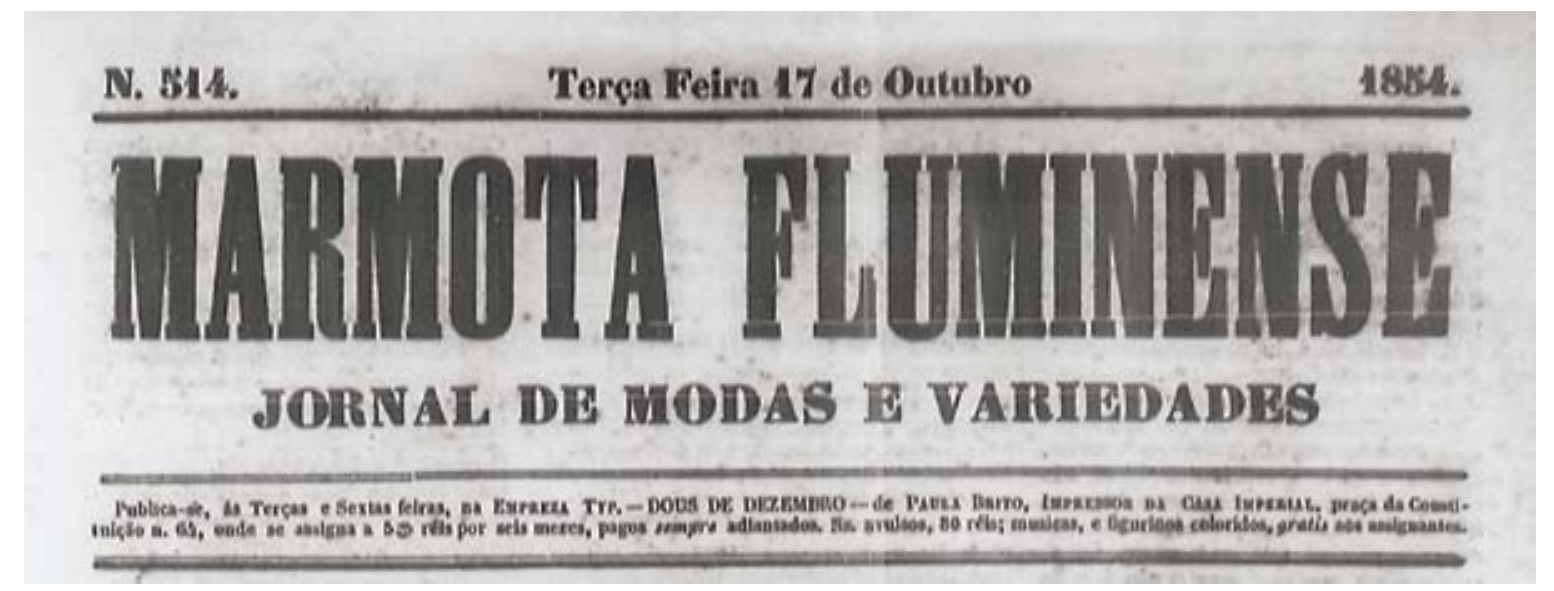

Figura 6. Cabeçalho da Marmota Fluminense em que consta o texto "Paula Brito, Impressor da Casa Imperial".

12. Idem, ib., p. XX.

13. O periódico está disponível para consulta na Biblioteca Nacional, informando seu período de circulação.

14. Moreira de Azevedo, op. cit., p. XXI. 
Moreira de Azevedo classifica o jornal como "agradável e variado", atribuindo como um de seus pontos principais o espaço aberto aos jovens, aos talentos nascentes.

A grande virtude conferida ao tipógrafo nesse texto foi seu incentivo à literatura brasileira - animando e protegendo os jovens autores -, pois "criara gazetas, revistas, para exercitar os moços na literatura, e mandava imprimir gratuitamente os seus dramas, romances e poesias"15.

Moreira de Azevedo garante que "era ainda vivo quandopedi-lhe apontamentos para escrever a sua biografia", ao que Paula Brito teria respondido: "nada mereço, doutor; lembre-se dos homens eminentes e não de mim"16.

Em 1 de dezembro de 1861 faleceu Teixeira e Sousa e, apesar de doente e acamado, Paula Brito não teria aberto mão de despedir-se pela última vez do amigo. Cogita-se a hipótese de que esse esforço, por parte do enfermo, tenha agravado sua própria doença, pois faleceu dias depois, em 15 de dezembro. Como se sabe, Teixeira e Sousa possui um perfil biográfico semelhante ao de Paula Brito. Mulato e pobre em uma sociedade escravista, teria, deixando de ser carpinteiro, vencido como artista por mérito e esforço pessoais, pois, como se verá abaixo, seu livro $O$ Filho do Pescador (1843) é considerado o primeiro romance da literatura brasileira. Não é difícil imaginar que a noção de que Paula Brito teria, no período grave de sua doença, deixado o leito para visitar o amigo pode ter sido criada para realçar uma possível identidade com o destino de Teixeira e Sousa.

Antes de morrer, Paula Brito ainda redigiu o necrológio do amigo, em que tornava público seu grande pesar pela perda de pessoa tão próxima e que o falecido deixava seis órfãos em situação de pobreza, de maneira que suplicava ao "respeitável corpo comercial" que refletisse antes de cobrar qualquer pendência da família. Observe-se um fragmento desse texto:

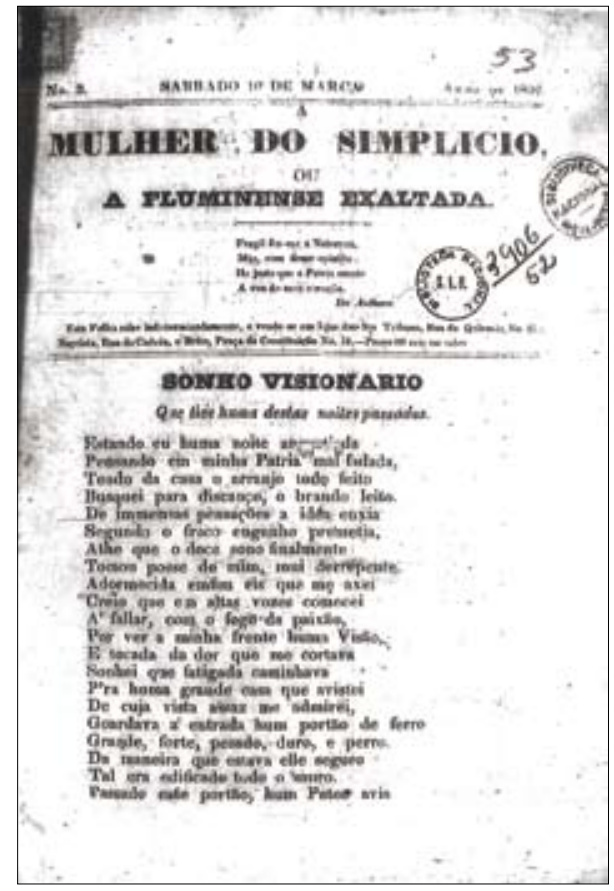

Figura 7. Primeira página de $A$ Mulher do Simplício ou A Fluminense Exaltada, de 10 de março de 1832.

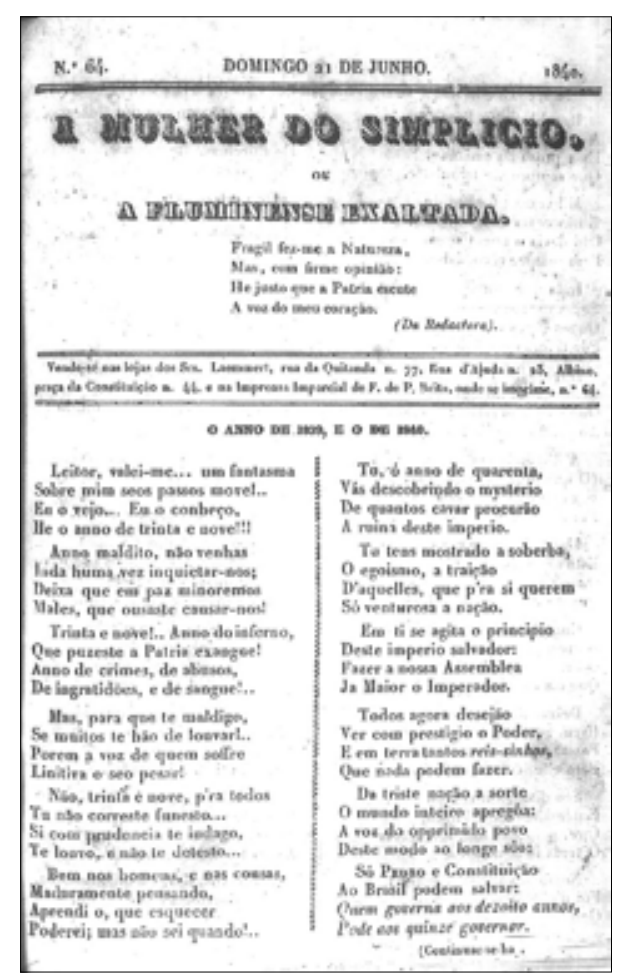

Figura 8. Primeira página de $A$ Mulher do Simplício, de 21 de junho de 1840. 
Nunca se passou o - Dia 2 de Dezembro - dia de nosso triste aniversário, sem que Teixeira e Sousa estivesse ao lado desse amigo, a quem prezava como a si próprio, no centro dessa família que ele amava como a sua: uma vez, porém, uma única vez, isto tinha de acontecer e aconteceu - foi ontem, porque ontem ele já não existia ${ }^{17}$.

Em seu leito de morte, afirma-se que Brito ainda dava conselhos a quem os procurasse e teria ditado várias cartas, uma, inclusive, destinada ao imperador solicitando proteção para sua família.

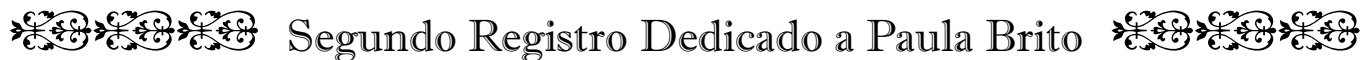

Quatro décadas após a publicação do texto de Moreira da Azevedo sobre Paula Brito, outra obra veio à luz com um ensaio biográfico sobre a mesma personagem. Artistas do Meu Tempo: Seguidos de um Estudo sobre Laurindo Rabelo, de Alexandre José de Melo Morais Filho ${ }^{18}$, dedica vinte de suas páginas ao tipógrafo. Os outros artistas abordados na obra, além de Brito e Rabelo, são Almeida Reis, João Caetano e Áreas, Carlos Kornis e Insley Pacheco, Dom José Amat, Carlos Gomes e Domingos Ferreira.

Percebe-se, facilmente, que o discurso de Melo Morais Filho funda-se no de Moreira de

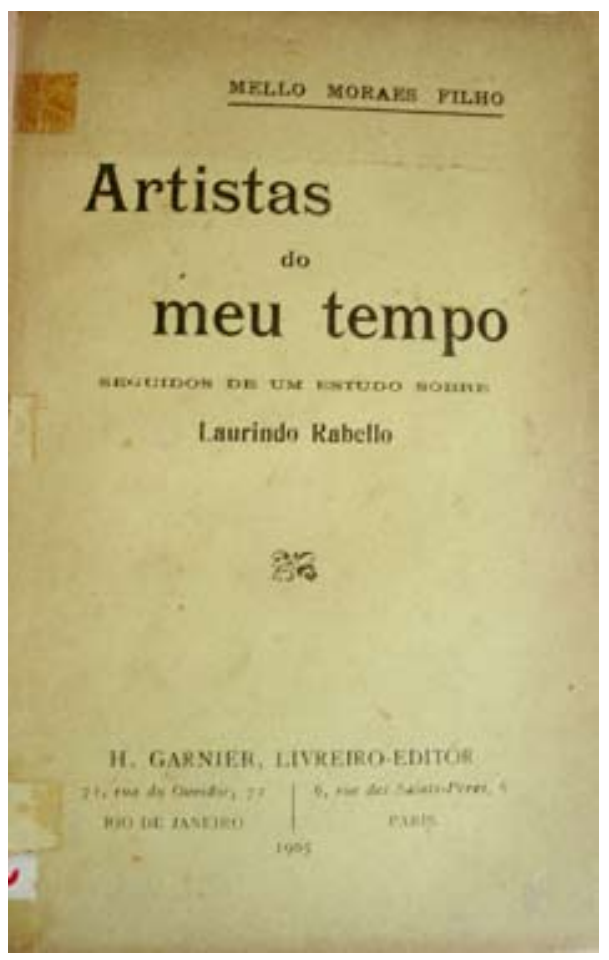
Azevedo, embora ambos procurem enfatizar aspectos distintos da vida da mesma personagem.

Melo Morais Filho inicia seu estudo informando que não pertence à geração que viu o tipógrafo florescer, mas àquela que o viu morrer. Talvez por isso, seu ensaio comece diretamente em 1831, ano em que Paula Brito adquiriu a loja de papel, cera e chá, no largo do Rossio, após ter sido impressor do Jornal do Commercio, que o autor afirma ser de propriedade de Plancher.

A seguir, Paula Brito teria adquirido um pequeno prelo e tipos, e montando no interior do estabelecimento uma tipografia. Aos poucos o local onde se lia "Loja de chá, do melhor que há" ${ }^{19}$ teria diminuído a venda desse tipo de produto,constituindo-seem espaçodedicadoprincipalmente ao comércio de livros e de serviços gráficos.

Melo Morais registra suas impressões sobre o tipógrafo:

Figura 9. Frontispício de Artistas do Meu Tempo.

17. A Marmota, n. 1.323 , p. 1, 6 dez. 1861

18. Rio de Janeiro, H. Garnier, 1905.

19. Melo Morais Filho, Artistas do Meu Tempo, p. 9. 
Quando conhecemos Paula Brito, já caminhava ele no declínio dos dias, sem os ardores das paixões patrióticas de outrora, na confiança inteira e segura dos radiosos destinos do Brasil.

De estatura mediana, de musculatura destituída de relevo, de cor tisnada como um califa dos contos árabes, o caráter dominante de sua fisionomia e do seu talento era uma mistura de bondade e delicadeza, fundidas em modéstia que se poderia confundir com humildade ${ }^{20}$.

Há pelo menos dois pontos de interesse nesse trecho: a caracterização, mesmo que não em termo literais, de Paula Brito como mulato e seu o exercício político.

Ao que se sabe, o verbo "tisnar" foi poucas vezes empregado na literatura brasileira, como por Gonçalves Dias no poema "O Homem Forte" e por Júlio Mário Salusse, no soneto "Cisnes". Embora o verbo tenha o sentido

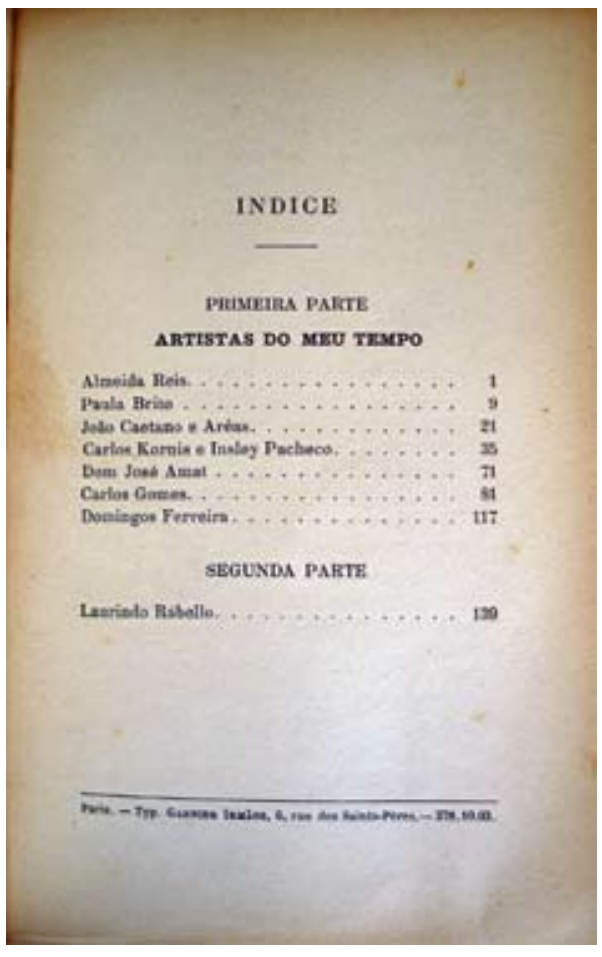

Figura 10. Índice da obra Artistas do Meu Tempo. primário de "enegrecer como carvão", há também uma certa conotação pejorativa que remete a "manchar" ou "macular". É interessante notar que após empregar essa palavra incomum, que pode ter sentido de desmerecimento, Melo Morais busca dignificar a figura do tipógrafo, conferindo-lhe o título de um soberano muçulmano. A comparação com um califa, além de imprimir enobrecimento, pode ser igualmente um artifício para amenizar certo preconceito contra a ascendência negra de Paula Brito.

De qualquer forma, pode-se conjeturar que em 1862, quando Moreira de Azevedo publicou o primeiro artigo sobre a vida de Paula Brito, ser mulato não era um traço com relevância suficiente para ser registrado, quatro décadas depois, tornou-se algo para ser divulgado.

Ao que parece, durante a sua juventude, o tipógrafo dedicou-se ativamente às questões políticas do país. Segundo Melo Morais, por exemplo, Paula Brito havia clamado pela regência de Dona Januária e combatido a favor da maioridade de Pedro II, como formas de ordenar o caos instaurado no país durante o Período Regencial. Seu retraimento, no campo político, talvez tenha atraído tanta atenção por ter se constituído em uma quebra do que seria antes uma atividade que envolvia muito empenho de sua parte.

Paula Brito contava apenas catorze anos quando Pedro I outorgou a primeira Constituição do Brasil, em março de 1824, após dissolver a Assembléia Constituinte com o apoio dos militares. A Constituição de 1824 - que vigorou com algumas alterações até o final do Império - definia o governo como monárquico, hereditário e constitucional. Entre outras regulamentações, ela instituiu o Poder 
Moderador, segundo o qual o soberano poderia nomear senadores, dissolver a Câmara, sancionar as decisões desta e do Senado, entre outros pontos. Logo, naquele momento o imperador, dominava a cena política no país.

No entanto, nos anos que se seguiram, Paula Brito pôde testemunhar o desgaste que a figura de seu monarca sofreu. O Brasil, que já havia pago pelo reconhecimento de sua Independência, endividou-se ainda mais com a guerra que declarou à Argentina e que perdeu em 1827, o Banco do Brasil já se encontrava em dificuldades e o custo de vida urbano aumentou. O Exército afastou-se de Pedro I, inconformado com a derrota e com a presença de portugueses no comando das tropas. O povo, levado à força para a frente de batalha, passou a rejeitar seu soberano. Os confrontos entre brasileiros e portugueses não cessavam. Além das crises internas e externas ligadas ao Brasil, pairava ainda sobre Dom Pedro a suspeita de que ele tentaria retroceder aos tempos de Reino Unido a Portugal e Algarves, caso assumisse o trono português (com a morte de D. João VI, em 1826). Em vista de todo esse cenário, Pedro I abdicou de coroa brasileira, em 7 de abril de 1831, em nome de seu filho de cinco anos e nomeou José Bonifácio como tutor da criança ${ }^{21}$.

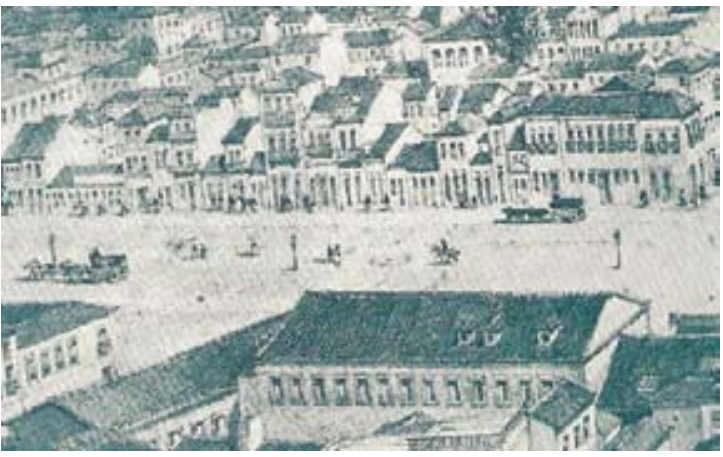

Figura 11. O Rossio em gravura de 1845, de Desmons. Na verdade, desde 1823 o nome oficial do local era praça da Constituição.
Dois meses depois da abdicação, formouse a Regência Trina Permanente, constituída por políticos liberais moderados. Estes se encontravam cercados pelas disputas entre exaltados, que defendiam a descentralização do poder, e absolutistas, que desejavam o retorno de Pedro I. Os arranjos feitos pelo imperador para garantir uma transição tranqüila do poder caíram imediatamente após sua partida e o país mergulhou em um período de turbulência generalizada ${ }^{22}$. Este era o panorama do Brasil quando Paula Brito começou a atuar em sua própria tipografia. Mesmo engajado

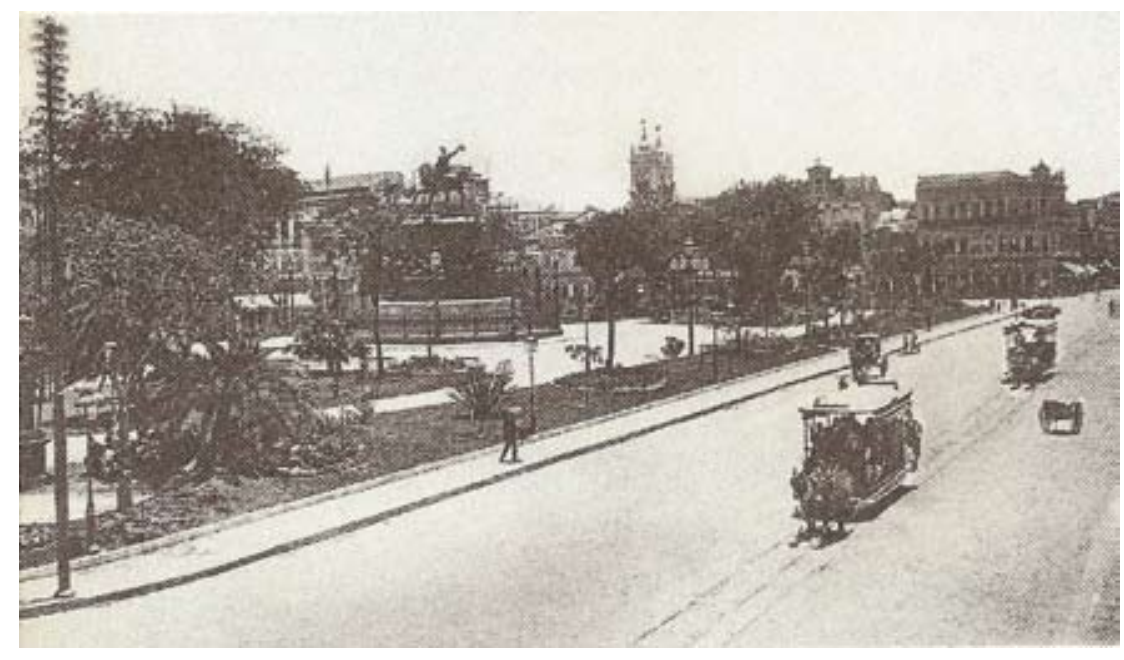

Figura 12. Após a Proclamação da República, a praça da Constituição foi rebatizada como praça Tiradentes. Fotografia de 1904 de Augusto Malta.

21. Boris Fausto, História do Brasil, pp. 154-158.

22. Eduardo Bueno, Brasil: Uma História, pp.179-180. 
na política, ele, ao mesmo tempo, buscava manter uma atmosfera relativamente pacífica dentro de seu estabelecimento, para garantir a presença do grupo que costumava freqüentá-lo.

Melo Morais Filho enfatiza a importância de Paula Brito como aglutinador da elite política de sua época:

Atravessando o período da Regência, sobrenadando ao ódio dos partidos em alarido nas ruas e praças, a tipografia de Paula Brito tornou-se por aquela época o cenáculo de eminentes personalidades, um terreno neutro onde vencedores e vencidos davam-se as mãos após os combates, ou temperavam as armas para mais veementes brigas ${ }^{23}$.

O autor enumera como freqüentadores da oficina do "artista mestiço": Justiniano José da Rocha, Alves Branco, Eusébio de Queirós, Honório Hermeto Carneiro Leão, Francisco Júlio Xavier, Joaquim Cândido Soares de Meireles, Firmino Silva, Bernardo de Vasconcelos, Montezuma, José Bonifácio e "dúzias de outros"24.

Buscando elementos para construir a figura de Paula Brito - entendida como uma personagem histórica e, portanto, resultante de discursos e pontos de vista - Melo Morais comenta sobre seu periódico, a Marmota:

De todo havia findado a sua missão política o eminente Paula Brito, quando, entregue aos esmeros de sua arte e ao cultivo das letras, redigia na segunda e terceira fase o distinto periódico que, com tanta superioridade, dera a nota espiritual e literária a esta sociedade, em rumo de aspirações altas.

Poeta de estreito vôo, escritor de boa índole, a publicação semanal da Marmota comprova a medida de seu talento literário e de seu valor poético ${ }^{25}$.

O autor talvez tenha sido o primeiro, mas não será o último, a questionar o valor de Paula Brito como poeta e escritor. No entanto, ele busca dar ênfase ao trabalho do tipógrafo apresentando sua loja como "poderoso centro em que o amor das letras, da pátria e da humanidade reunia os talentos, as

23. Melo Morais Filho, op. cit., p. 11.

24. Idem, ib., p. 12. Sobre os nomes citados: Justiniano José DA Rocha (1812-1862), jornalista e panfletário, dirigiu e fundou vários periódicos, entre os quais O Regenerador, publicado a partir de 1860; MANUEl Alves Branco (17971855), o visconde de Caravelas, foi juiz de fora, advogado, economista e político; Eusébio de QueIrós Coutinho Matoso DA CÂmara (1812-1868) foi magistrado e político brasileiro, durante sua atuação como ministro da Justiça foi o autor da Lei Eusébio de Queirós, que reprimia o tráfico negreiro e estabelecia sua posterior extinção; HoNóRIO Hermeto Carneiro Leão (1801-1856), primeiro e único visconde com honras de grandeza, conde e marquês de Paraná, atuou como diplomata, juiz de fora e político; Francisco Júlio Xavier (1809-1850) médico e político, recebeu o título de oficial da Ordem da Rosa por seus serviços durante uma epidemia de febre amarela; JOAQUiM CÂNDIdo SoARes de MeIreles (1797-1868) foi um médico cirurgião-mor e político brasileiro; Firmino Rodrigues SILVA (1816-1879) formou-se em direito, atuou como jornalista, político, poeta e foi senador do Império; BERNARDO Pereira de Vasconcelos (1795-1850) foi político, jornalista, juiz de fora e jurista brasileiro; Francisco GÊ Acaiaba de Montezuma (1794-1870), visconde de Jequitinhonha, foi advogado, jurista e político, mudou seu nome de batismo - Francisco Gomes Brandão - após a proclamação da Independência; José Bonifácio DE ANDRADA E Silva (1763-1838), conhecido como "Patriarca da Independência", foi naturalista, estadista e poeta.

25. Melo Morais Filho, op. cit., p. 16. 
classes, e até mesmo os partidos opostos"26. Registra que, durante o romantismo, o estabelecimento reunia expoentes da então "nova escola" como Magalhães, Gonçalves Dias, Porto-Alegre, Macedo, Teixeira e Sousa, e ainda que:

E quantos não deveram ao tipógrafo-editor fecundas animações, o enfeixamento em volume de esplêndidas produções, que figuraram sucessivas nas estantes e nos mostradores daquela livraria? Que o digam os colaboradores da Marmota, do Guanabara e outros periódicos; que o respondam Teixeira e Sousa, Martins Pena, Joaquim Norberto, Machado de Assis, Constantino Gomes de Souza, Bruno Seabra e a plêiade gloriosa das vocações de outrora, que encontravam em Paula Brito um ponto de vista às suas aspirações, um guia confiante e remontadas eminências ${ }^{27}$.

Para Melo Morais, a tipografia de Paula Brito não era apenas o ponto de encontro de políticos e literatos. Durante a existência da Ópera Nacional e nas temporadas mais concorridas do Teatro Lírico, sempre que alguma companhia chegava ao Rio de Janeiro, era a loja do Rossio que as celebridades buscavam, para encontros e debates sobre artes. Essa preferência não era gratuita, pois, segundo o autor, era na tipografia de Brito que muitas das poesias dedicadas às cantoras eram impressas, elaboradas pelos freqüentadores do local.

Ainda com referência às composições tipográficas que eram impressas na casa, mencionase: “[...] convém lembrar que de seus prelos saiu a Confederação dos Tamoios, de Domingos José de Gonçalves Magalhães, obra de tiragem especial, cujas provas passavam pela revisão do Imperador"28.

Propondo-se a divulgar um fato inédito sobre Francisco de Paula Brito, Melo Morais Filho atesta que em 1857 chegou à capital do Império, vindo da Bahia, um senhor "decaído de fortuna e de popularidade, à procura de uma migalha oficial para escapar à fome" ${ }^{29}$. Afirmou-se que essa pessoa seria o coronel Inácio Acióli de Cerqueira e Silva, historiador e autor de obras memorialísticas, que havia lutado pela Independência do Brasil. O homem, sem quaisquer recursos materiais, haveria se dirigido até a loja de Paula Brito e lá teria encontrado algum alívio para suas dificuldades, amparado pelo tipógrafo. Sem dúvida, essa observação acrescenta uma nota de piedade bastante compatível com o retrato romântico que então se compunha do impressor, ao qual não falta, como se vê, inteireza de caráter, dignidade, dedicação, empenho, esforço, identidade com a profissão, persistência e... pouco talento.

Após a morte de Brito, informa-se que carregaram seu caixão Eusébio de Queirós, Paranhos, Joaquim José Inácio, Saldanha Marinho, Paulino e dr. Severino Martins. As últimas palavras de Melo Morais sobre o perfil de Brito são: "Da arte tipográfica no Brasil foi ele o mais legítimo representante, a mais transcendente irradiação" ${ }^{30}$.

26. Melo Morais Filho, op. cit., p. 16.

27. Idem, ib., p. 17.

28. Idem, ib., p. 18.

29. Idem, ib., p. 19.

30. Idem, ib., p. 20. 


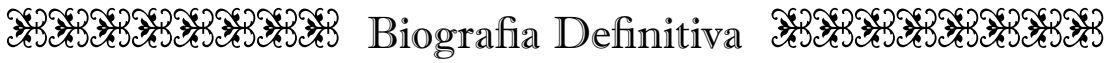

\section{Resgate das Idéias Iniciais}

Em 1965 veio à luz a primeira, e até onde se sabe, única, obra inteiramente dedicada ao tipógrafo, Vida e Obra de Paula Brito: Iniciador do Movimento Editorial no Rio de Janeiro (1809-1861), de Eunice Ribeiro Gondim.

Nas primeiras páginas de seu texto, informa-se que muitas são as obras que mencionam Paula Brito, intencional ou acidentalmente, ligando-o a grandes nomes da literatura, principalmente do período romântico. Isso porque ele teria apoiado e incentivado aqueles que em sua época eram jovens iniciantes, e depois se tornariam autores consagrados. Gondim, no entanto, afirma que é com pesar que encontra, em certos textos, definições acerca de Paula Brito nas quais é possível perceber a tentativa de desprestígio, "de torná-lo pequeno por sua origem humilde, pobre, por ser mestiço e não ter logrado fazer um curso regular" e continua:

Enganaram-se aqueles que assim pensaram. Toda a grandeza de Paula Brito está, justamente, em ter conseguido vencer todas essas adversidades, que lhe advieram independentes de sua própria vontade, pois a ninguém é dado escolher como e onde nascer. Como viver, sim, pertence ao indivíduo, no seu livre arbítrio, no poder que tem de escolher, bem ou mal, o seu caminho, a comando de sua vontade.

O tipógrafo, o livreiro, o editor, o poeta e o jornalista, surgiram da vontade férrea de um homem, encaminhado, sempre, pelo desejo patriótico do engrandecimento da terra natal, dependesse dele ou de outro alcançar esse fim. Não havia nele inveja das glórias alheias. Fazia-as suas, pôde senti-las, com a mesma alegria de alma de um pai, quando vê um filho receber honrarias ou merecer reconhecimento público de valor ${ }^{31}$.

No texto, chega-se a nomear Lúcia Miguel Pereira como uma das ensaístas que teria uma visão deturpada de Paula Brito, por julgá-lo e questionar sua contribuição à história da cultura sem tentar enquadrá-lo no período e nas condições em que viveu.

Eunice Ribeiro Gondim, como se percebe, dá continuidade às bases lançadas por Machado de Assis para o discurso sobre Paula Brito - personalidade amigável e tolerante, cujo espírito generoso buscava sempre apoiar os jovens, mesmo em virtude da escassez de recursos financeiros. Ela abandona, de certo modo, a pregação de Moreira de Azevedo, que busca infundir ares mais elitizados ao tipógrafo - qualificando-o como neto de artista e como participante da cena política de seu tempo. Do repertório desse autor, ela absorve a idéia do self made man - aquele que começou impressor e chegou a ser editor de destaque na capital do Império -, a de protetor da juventude e de incentivador da literatura nacional. Como Melo Morais Filho, que é o primeiro a caracterizar Paula Brito como

31. Eunice Ribeiro Gondim, Vida e Obra de Paula Brito, p. 10. 
negro, a autora resgata esse pormenor, no entanto, ela passa a usá-lo para criar a idéia de uma minoria excluída, chamando-o "pobre" e "mestiço".

Para bem definir o tipo de discurso elaborado por Eunice Ribeiro Gondim acerca de Francisco de Paula Brito, algumas de suas palavras iniciais são de grande importância: "estamos situados em um ângulo de admiração, que nos levará a fazer um retrato simples e fiel, embelezado pelo que é bom e digno na transparente personalidade de Paula Brito" 32 . A autora assume abertamente seu ponto de vista elogioso em relação ao objeto de estudo, chegando mesmo a gerar uma certa atmosfera subjetiva na biografia. Observa-se, ainda aqui, que, sendo escassas as fontes documentais, a biógrafa sente-se um pouco dona da matéria, compondo um retrato a partir de uma perspectiva um tanto livre, como se a identidade do biografado dependesse exclusivamente do estilo de seu texto. Enfim, essa noção não contradiz certa idéia segundo a qual a história, tal como a literatura, depende muito do estilo ou do ponto de vista do escritor.

Partindo das origens de Paula Brito, a autora informa que ele nasceu no Rio de Janeiro, em 2 de dezembro de 1809, na rua do Piolho, no 148, filho do carpinteiro Jacinto Antunes Duarte e Maria Joaquina da Conceição Brito. Aos seis anos, ele teria se mudado com a família para Suruí - que naquela época era um dos distritos da vila de Magé (hoje, uma das cidades da Baixada Fluminense). Paula Brito teria sido alfabetizado por uma irmã mais velha e ao completar quinze anos teria retornado à capital do Império na companhia do avô, o toreuta e sargento-mor Martinho Pereira de Brito.

Ao que se sabe, Paula Brito trabalhou na farmácia de Domingos Gonçalves Valle e depois conseguiu uma vaga como aprendiz de artes gráficas na Tipografia Imperial e Nacional. Tempos depois, transferiu-se para a Tipografia de R. Ogier e, posteriormente, para a de Pierre Plancher, em cujo periódico, o mencionado Jornal do Commercio, teria iniciado suas atividades de redator, além de aprofundado seus conhecimentos sobre tipografia.

Em 1831, conforme estabelecido por Moreira de Azevedo, Paula Brito adquiriu de seu primo um ponto comercial, na praça da Constituição ${ }^{33}$, local então conhecido como Largo do Rossio. Nesse estabelecimento ele instalou seu primeiro prelo, dando início a seus trabalhos tipográficos.

Segundo Gondim, funcionavam no Rio de Janeiro, por aqueles anos, a Tipografia Imperial e Nacional, a Tipografia do Diário, l'Imprimerie de Gueffier et Co., a Tipografia Imperial e Constitucional de Seignot-Plancher, a R. Ogier, a Astréa, a Imperial e Constitucional de J. Villeneuve, a de Laemmert e outras menores. Como se sabe, apesar do número considerável de estabelecimentos, grande parte das obras brasileiras ainda era impressa fora do país, principalmente em França e Portugal. Parte dessa iniciativa decorre, geralmente se supõe, da soberania cultural francesa na época. Por outro lado, havia também a questão da carência de recursos técnicos mais apurados no Brasil.

32. Idem, ib., p. 12.

33. Comentando sobre a loja comprada pelo tipógrafo, Moreira de Azevedo assevera: "Este estabelecimento era na Praça da Constituição n. 21" (ver: "Biografia”, em Poesias de Francisco de Paula Brito, p. XII). No entanto, Eunice Ribeiro Gondim afirma que todas as obras e jornais que consultou, editados entre 1832 e 1836, trazem como endereço da tipografia “praça da Constituição no 51" (op. cit., p. 37). 


\section{Homem das Letras}

Gondim busca, repetidamente, qualificar Paula Brito como possuidor de um nível cultural elevado, com colocações da seguinte espécie: "Foi impressor da Casa Imperial, e além de hábil artista era literato e poeta $[. .].]^{\prime 34}$. A autora chega até mesmo a justificar afirmações de seu biografado, quando este se assumia como pessoa pouco letrada. No soneto "A Moda dos Homens em 1828", primeiramente divulgado na Mulher do Simplício e depois republicado na Marmota Fluminense, Paula Brito escreve sobre si mesmo: "porque eu tinha então pouca leitura, e quase nenhuma instrução" ${ }^{35}$. Gondim rebate essa idéia, afirmando que ele estaria mais "externando a opinião ditada pela evolução, sempre crescente, de seus conhecimentos, do que dizendo uma verdade de fato"; pois para ela desde 1831 ele já escrevia com facilidade, tendo aprimorado sua técnica de redação posteriormente, tanto com o português como com o francês ${ }^{36}$. Como se percebe por essa passagem, a autora parece confundir a voz poética do texto de Paula Brito com o suposto eu empírico do biografado. Mesmo que essa afirmação surja em nota ao poema, parece aceitável admitir a nota como parte da ficção poética, e não como documento de valor propriamente histórico sobre o autor ${ }^{37}$.

Observe-se o poema gerador de tal controvérsia:

\section{O LiVRinho das MoçAS}

Poesias de Paula Brito

desde os 18 anos até hoje, e que algum dia serão impressos em um ou mais volumes.

\section{SONETO}

A Moda dos Homens EM 1828

Grossos bucres armados no cabelo,

Chapéu de finas abas enroladas,

Camisas de aberturas enfeitadas

Calças largas no fino tornozelo;

Casacas, que de caudas são modelo;

Sapatos sem tacão, meias rajadas;

Bengalinas de junco encastoadas

Dum cãozinho, duma ave, ou dum camelo;

34. Eunice Ribeiro Gondim, op. cit., p. 21.

35. Marmota Fluminense, 4 mar. 1856.

36. Eunice Ribeiro Gondim, op. cit., p. 20.

37. Ivan Teixeira propõe a idéia de que, geralmente, as notas aos textos poéticos partilham da mesma natureza ficcional dos poemas. Segundo essa hipótese, pode-se admitir que Paula Brito, em sua nota, adiciona um componente imaginoso ao argumento do texto, imitando o estilo documental dos textos históricos. Mas o efeito da nota é de adição à fantasia do texto, cuja estrutura parece seguir o padrão do conhecido soneto de Bocage "Magro, de olhos azuis, carão moreno". Cf.: “O Uraguai: Diatribre contra o Regicídio e contra a Monarcomaquia”, em Épicos, pp. 173-176. 
De amarelo metal grandes botões,

Hoje têm entre nós muito exercício,

Em fofos peitos que usam toleirões.

Mil graças sejam dadas ao Simplício (1)

Que, com suas freqüentes mangações,

Censura as modas e combate os vícios.

(1) - O Simplício foi o primeiro jornal faceto que apareceu no Rio de Janeiro; seguiu-se-lhe a MulHer do Simplício - de minha redação, e que foi sempre muito bem aceita nesta Corte, em cujo $1^{\circ}$ número lê-se este Soneto, menos castigado do que agora se acha, porque eu tinha então pouca leitura, e quase nenhuma instrução.

Com a finalidade de gerar argumentos para sua idéia de que Paula Brito, além de mestre das artes gráficas, foi também um expoente do movimento literário de seu tempo, Gondim seleciona ainda outros trabalhos divulgados em a Marmota, como o soneto a seguir, que foi publicado em 15 de janeiro de 1856:

Como talvez publiquemos algum dia um volume de nossas linhas rimadas, antigas e modernas; vamos, por ora, fazendo delas um pequeno depósito nas colunas dessa nossa folha; podendo desde já assegurar a nossos leitores, que aquilo que aparecer com nosso nome, bom ou mal - é nosso.

\section{Mote}

"Feliz quem junto a ti por ti suspira!"

SONETO

Eu quisera encontrar uma donzela

Que somente por mim se apaixonasse,

Que dia e noite só em mim pensasse

Ao ver-me noite e dia a pensar nela!

Embora com primor não fosse bela

Quisera que extremosa me afagasse!

Que de mim nunca os olhos apartasse,

Eu quisera encontrar uma donzela!

Se eu achasse uma assim; se assim houvesse

Mulher de arrebatar de um vate a lira,

Que ditoso no mundo me fizesse,

Tudo o que pode o amor, e o gênio inspira

Lhe dera, se uma só vez me dissesse:

"Feliz quem junto a ti, por ti suspira!"

1830 - Paula Brito 
Embora a autora entenda que a temática dos versos de Brito sejam recorrentes naquele período (chama-a "amorosa, fácil, leve, por vezes ingênua"); consciente das diferenças entre a qualidade literária das produções do tipógrafo e dos grandes nomes do período, ela destaca:

Não defendemos aqui, a grandeza da obra poética de Paula Brito, mas o valor do poeta sóbrio, sincero, do homem inteligente e culto, à altura dos que o eram em sua época, sem colocá-lo, entretanto, em confronto com os excepcionais valores, que brilharam na privilegiada época do romantismo brasileiro $[\ldots]^{38}$.

À parte sua crença, talvez excessiva, no valor da poesia romântica, ela busca apresentar um perfil intelectual daquele período que pareça adequado aos seus argumentos. A seu ver, os avanços alcançados pelo grupo da escola romântica constituíam, na verdade, uma exceção. Pois a cultura da população mediana não ultrapassava um nível considerado primário. As mulheres, em alguns casos, sequer eram alfabetizadas. E grande parte dos homens detinha-se nos conhecimentos necessários para o desenvolvimento de uma carreira comercial.

Para Gondim, havia duas alternativas para os espíritos interessados em estudar e adquirir um grau mais elevado de cultura. A primeira era guardada aos que dispunham de recursos financeiros suficientes para tornarem-se doutores, buscando muitas vezes na Europa sua formação acadêmica. A segunda, no entender da autora, era o do autodidatismo; da qual Paula Brito tomou parte, pois "procurou suprir deficiências com leitura constante e atenta dos bons autores portugueses, pela comparação e análise, mas conservando sempre intacta sua personalidade"39.

Com vistas a não deixar dúvidas de que Paula Brito foi um legítimo representante da poesia romântica, Gondim alude à obra organizada por Laudelino Freire, Sonetos Brasileiros, na qual são apresentados dois sonetos do tipógrafo, na primeira e na segunda edição. O soneto constante na edição de 1904, a primeira, é:

\section{SONETO}

O que viste, poeta? - O que não viste.

Ganhas ou perdes? - Perco a liberdade.

Que viste, pois? - Vi uma divindade.

Que ao teu amor resiste? - Não resiste.

Em amar-te, persiste? - Não persiste.

A verdade não falas? - A verdade!

Que almejas em querê-la? - A f'licidade.

Pois há isso sem amor? - Só nele existe.

38. Eunice Ribeiro Gondim, op. cit., p. 26.

39. Idem, ib., p. 27. 


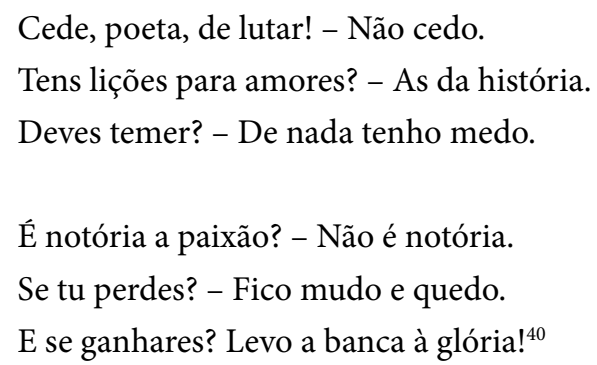

Buscando atribuir a seu biografado ainda outras qualidades intelectuais, Gondim lembra que Brito atuou também como redator e tradutor ${ }^{41}$.

Segundo ela, entre 1839 e 1840, mesmo depois de montar sua própria tipografia e fundar A Mulher do Simplício ou a Fluminense Exaltada, o tipógrafo continuou colaborando ativamente no Jornal do Commercio. São dele as traduções de "A Espiã ou o Segredo dos Carbonários", conto de Frédéric Soulié; "João sem Medo ou a Justiça dos Maridos", conto de Pitre Chevalier; o conto "O Pontífice e os Carbonários" e o romance Othon, o Arqueiro: Crônicas das Margens do Reno ambos de Alexandre Dumas; Madame Talon, romance de Jules A. David; além de outros textos de Émile Souvestre e Crétineau Joly. No mesmo periódico, Paula Brito publicou ainda trabalhos de sua autoria, como os contos “O Enjeitado" (1839), "A Mãe-irmã (História Contemporânea)” (1839) e "A Revelação Póstuma” (1839).

\section{As Tipografias}

Há um registro, por parte do próprio Paula Brito, sobre o início de seu trabalho como tipógrafo:

[...] O anunciante não tendo aprendido nenhuma outra arte, nem ofício, desde que deixou de ser caixeiro do Sr. Domingos Gonçalves Valle, farmacêutico nesta corte (hoje residente em S. João do Príncipe), para onde veio de Suruí, onde foi criado, tem empregado todo o seu tempo, cuidado, e gosto, em aumentar de dia em dia, à custa de penosos sacrifícios, a pequena tipografia que comprou ao Sr. E. C. dos Santos, com a qual principiou a desenvolver-se na arte que tanto estima $[. . .]^{42}$.

Sabe-se que após a aquisição do ponto comercial, em 1831, e posteriormente do maquinário tipográfico, Paula Brito instalou sua empresa na praça da Constituição, no 51 . Inicialmente, imprimia em seus trabalhos o nome Tipografia Fluminense de Brito \& Cia. e a partir de 1833 começou a empregar, também, a variação Tipografia Imparcial de Brito.

Alguns anos depois, em 1837, a empresa foi transferida para o no 66 da praça da Constituição.

40. Laudelino Freire, Sonetos Brasileiros, p. 51.

41. Eunice Ribeiro Gondim, op. cit., p. 22.

42. A Marmota na Corte, n. 36, p. 1, 15 jan. 1850. 
Em seguida, as instalações foram ampliadas, ocupando também o no ${ }^{-64}$. Este último endereço foi o mais conhecido de Paula Brito e, conseqüentemente, o mais divulgado.

Em 1850 - ano de lançamento da Empresa Tipográfica Dous de Dezembro - Brito aumentou, ainda mais, o número de estabelecimentos que dirigia. Além dos nos 64 e 66 da praça da Constituição, foram incorporados também os $\mathrm{n}^{\mathrm{os}} 68$ e 78; havia outro ponto na rua da Lampadosa, $\mathrm{n}^{\mathrm{os}} 35$ e 37 ; a litografia passou a funcionar na rua dos Ciganos, no 28, em 1855; e na rua dos Ourives, no 21, estava em atividade a Tipografia de Paula Brito.

Ao que parece, Brito criou a Empresa Tipográfica Dous de Dezembro abrindo capital e lançando ações para venda, com o objetivo de captar mais recursos financeiros para investir na ampliação do negócio. Em dezembro de 1851, ele anunciava a venda dos títulos e as vantagens para quem os adquirisse, usando como forma de "propaganda" a participação do imperador como acionista:

\section{Ações da Empresa Tipográfica Dous de Dezembro por F. De Paula Brito}

Restam ainda 19, das 75 que o empresário emite. As pessoas que tomarem alguma destas ações, até 20 do corrente, terão a vantagem do prêmio de 6 por \%, contado desde o 1으 de julho, assim como todos os jornais e obras da empresa, gratuitamente, na forma do plano que corre impresso.

São acionistas, e acham-se inscritos, além de Suas Majestades Imperiais, os Ilmos. e Exmos. Srs. [... $]^{43}$.

Eunice Ribeiro Gondim informa - como fez Gondin da Fonseca em estudo anterior ${ }^{44}$ - que a liquidação da Empresa Dous de Dezembro, em 1857, acarretou a Paula Brito, o principal proprietário, enorme prejuízo: "Perdeu quase tudo o que possuía. Assistiu, com tristeza, à venda pública dos seus instrumentos de trabalho, que com tanto esforço e sacrifício conseguira reunir” ${ }^{35}$. Em um artigo, o tipógrafo esclarece a situação e presta contas aos demais sócios do empreendimento:

Exposição de Francisco de Paula Brito, na Reunião, QUe ontem teve lugar, dos aCionistas e CREDORES da Empresa Dous de Dezembro

\section{$[\ldots]$}

A maior parte das ações da atual empresa estão convertidas, e à exceção de alguns poucos acionistas, que hesitam, o resto não duvida fazer tudo o que for preciso em benefício meu e da própria empresa.

Há credores que reclamam pagamento sem fazer concessão alguma [...].

Nesta colisão, procurei recursos ainda os mais extraordinários e do mais elevado grau; nada, porém, tendo podido conseguir, talvez pelas circunstâncias da atualidade, ou

43. A Marmota na Corte, n. 215, p. 4, 2 dez. 1851.

44. Gondin da Fonseca, Machado de Assis e o Hipopótamo, p. 88.

45. Eunice Ribeiro Gondim, op. cit., p. 40. 
da minha falsa posição, uma semelhante contrariedade resolveu para mim o problema de que a atual empresa devia cessar, embora mais de 60 pessoas, ou antes, mais de 50 famílias, ficassem em completo desarranjo ${ }^{46}$.

E nessa mesma matéria, ele continua sua exposição, informando que os acionistas deviam reavaliar a situação e buscar salvar a empresa, não por ele - "porque vigoroso ainda, ganharei em qualquer parte o pão diário com o suor do meu rosto" -, nem pelo país - "porque o país bem pouco se importa com o que se faz por ele, nem com aqueles que por amor dele se sacrificam" -, mas sim por seus próprios interesses. Pois Paula Brito acreditava que a empresa poderia ainda ter um "brilhante futuro", se fosse adequadamente conduzida e se surgissem interessados em ajudá-lo "em tantos e tão ativos trabalhos" ${ }^{37}$.

Apesar dos esforços, Brito não conseguiu evitar a liquidação da Empresa Tipográfica Dous de Dezembro. Alguns pontos comerciais onde funcionavam as lojas foram vendidos, outros fechados, mas ele conseguiu manter o endereço na praça da Constituição, no ${ }^{\circ 4}$, onde a Tipografia de Paula Brito permaneceria em atividade até o final de seus dias.

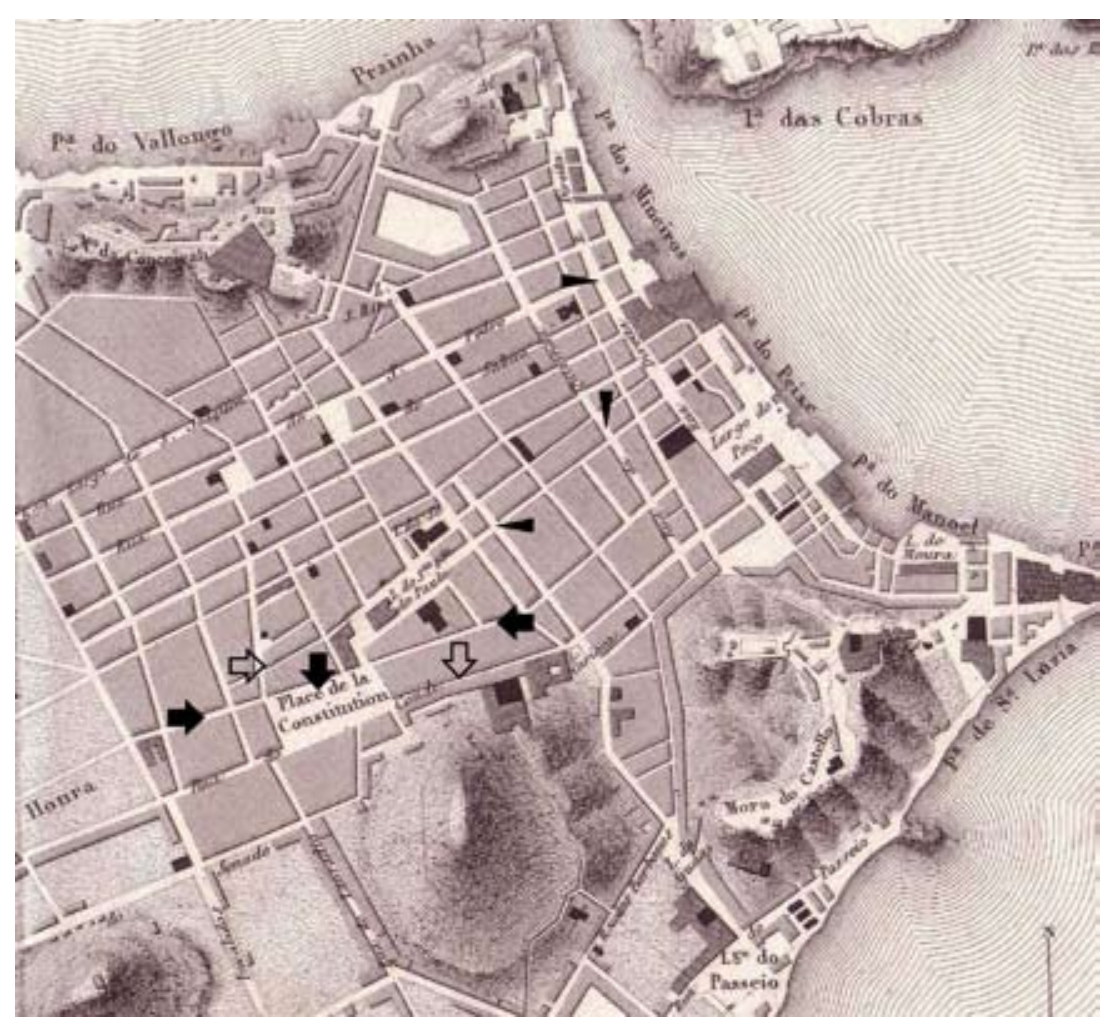

46. Marmota Fluminense, n. 790, p. 1, 28 out. 1856.

47. Idem, ib.
Figura 13. Detalhe do mapa da cidade do Rio de Janeiro em 1838, de Dufour e Desbuissons, publicado por Jules Renouard. As áreas escuras indicam igrejas ou conventos e as setas, ruas.

$\checkmark$ praça da Constituição; $\sqrt{ }$ rua da Carioca; $\Rightarrow$ rua da Lampadosa; rua do Cano; $\Rightarrow$ rua dos ciganos; | rua da Quitanda; - rua Direita; rua do Ouvidor. 


\section{Produção de Paula Brito}

Tendo durante toda a sua existência se dedicado às artes tipográficas, além de produzir e imprimir seus próprios periódicos, Paula Brito também oferecia seus serviços gráficos a quaisquer outras folhas que o contratassem. Além de tentar pontuar alguns desses jornais citados por Eunice Ribeiro Gondim, neste texto busca-se também indicar algumas das obras que saíram de suas oficinas, com a finalidade de caracterizar a produção editorial do tipógrafo.

Gondim pouco se detém em explicações sobre o primeiro periódico de propriedade de Paula Brito, A Mulher do Simplício ou A Fluminense Exaltada. Afirma que a folha teve uma boa aceitação em seu tempo e que permanece como uma fonte interessante de informações sobre a época, pois tratava de diversos assuntos - modas, divertimentos e crônicas diárias - na forma de versos. A autora oferece igualmente escassas informações sobre a Marmota, lembra que o nome da folha passou por alterações A Marmota na Corte (1849-1852), Marmota Fluminense (1852-1857) e A Marmota (1857-1861) - e que o periódico contou com diversos colaboradores, sobretudo amigos de Brito, durante sua existência. Há no presente trabalho um capítulo específico sobre a posição desse periódico na cultura brasileira.

Mencionam-se aqui alguns dos jornais e revistas impressos por Brito. Como o propósito do presente capítulo não é bibliográfico, não se oferece a relação completa de suas publicações. Com a finalidade de examinar a variedade dos temas dos periódicos editados pelo impressor, os títulos foram selecionados em virtude de sua data de circulação e de sua importância histórica ${ }^{48}$ :

- O Conciliador Fluminense: Jornal Político, Histórico e Miscelânico - Tipografia Fluminense de Brito \& C., 1832.

- O Restaurador - Tipografia Fluminense de Brito \& C., 1833.

- O Sentinela da Liberdade no Rio de Janeiro - Tipografia Brito \& C., 1833.

- O Tamoio Constitucional - Tipografia Fluminense de Brito \& C., 1833.

- O Estafeta Monárquico - Tipografia Fluminense de Brito, 1835.

- A Novidade - Tipografia Fluminense de Brito \& C., 1835.

- Revista Médica Fluminense - Tipografia Imparcial de Brito, 1835 a 1840. Após várias alterações de títulos, este periódico é publicado ainda hoje com o nome de Anais da Academia Nacional de Medicina.

- Seleta Católica: Jornal Religioso - Tipografia Imparcial de Brito, 1836 a 1837.

- O Repúblico - Tipografia de F. de Paula Brito, 1837.

- O Católico Fluminense - Tipografia Imparcial de Brito, 1838.

- D. Pedro II - Tipografia Imparcial de F. de Paula Brito, junho a setembro de 1838.

- O Monarquista do Século 19 - Imprensa de Brito e Imprensa Imparcial, agosto de 1839.

- O Ônibus de Niterói: Jornal Político e Literário - Tipografia Niterói de Rego e Tipografia Imparcial de Brito, 1840 a 1841.

48. A mais ampla relação de materiais impressos por Francisco de Paula Brito, que se tem conhecimento até o presente momento, encontra-se em: Eunice Ribeiro Gondim, op. cit., pp. 78-114. 
- A Regeneração - Tipografia Imparcial de Francisco de Paula Brito, circulou de agosto de 1840 a março de 1841.

- Arquivo Médico Brasileiro: Gazeta de Medicina, Cirurgia e Ciências - tomo I, Tipografia Imparcial de Paula Brito, 1844 (redigido por Ludgero da Rocha Ferreira Lapa).

- A Nova Gazeta dos Tribunais - Tipografia de Francisco de Paula Brito e Tipografia Brasiliense, 1848 a 1849.

- A Religião: Periódico Religioso e Político - Tipografia de Paula Brito e Tipografia do Diário de L. N. Viana, 1848 a 1850.

- Guanabara: Revista Mensal, Artística, Científica e Literária - dirigida por Manuel de Araújo Porto-Alegre, Gonçalves dias e Joaquim Manuel de Macedo, Tipografia da Empresa Dous de Dezembro, 1849 a 1856.

Ainda, na Fundação Biblioteca Nacional é possível consultar os seguintes títulos impressos por Paula Brito:

- O Clarim da Liberdade - circulou entre 1831 e 1833; foi impresso em várias tipografias além da Tipografia Fluminense de Brito, cita-se aqui: Tipografia de R. Ogier, Tipografia de Lessa e Pereira e Tipografia de Torres.

- O Homem de Cor - esta folha teve o título alterado a partir do terceiro número para O Mulato ou o Homem de Cor, foi impressa na Tipografia Fluminense de Brito \& C. e circulou entre setembro e novembro de 1833; ao que se sabe, foi o primeiro periódico brasileiro dedicado à luta contra o racismo.

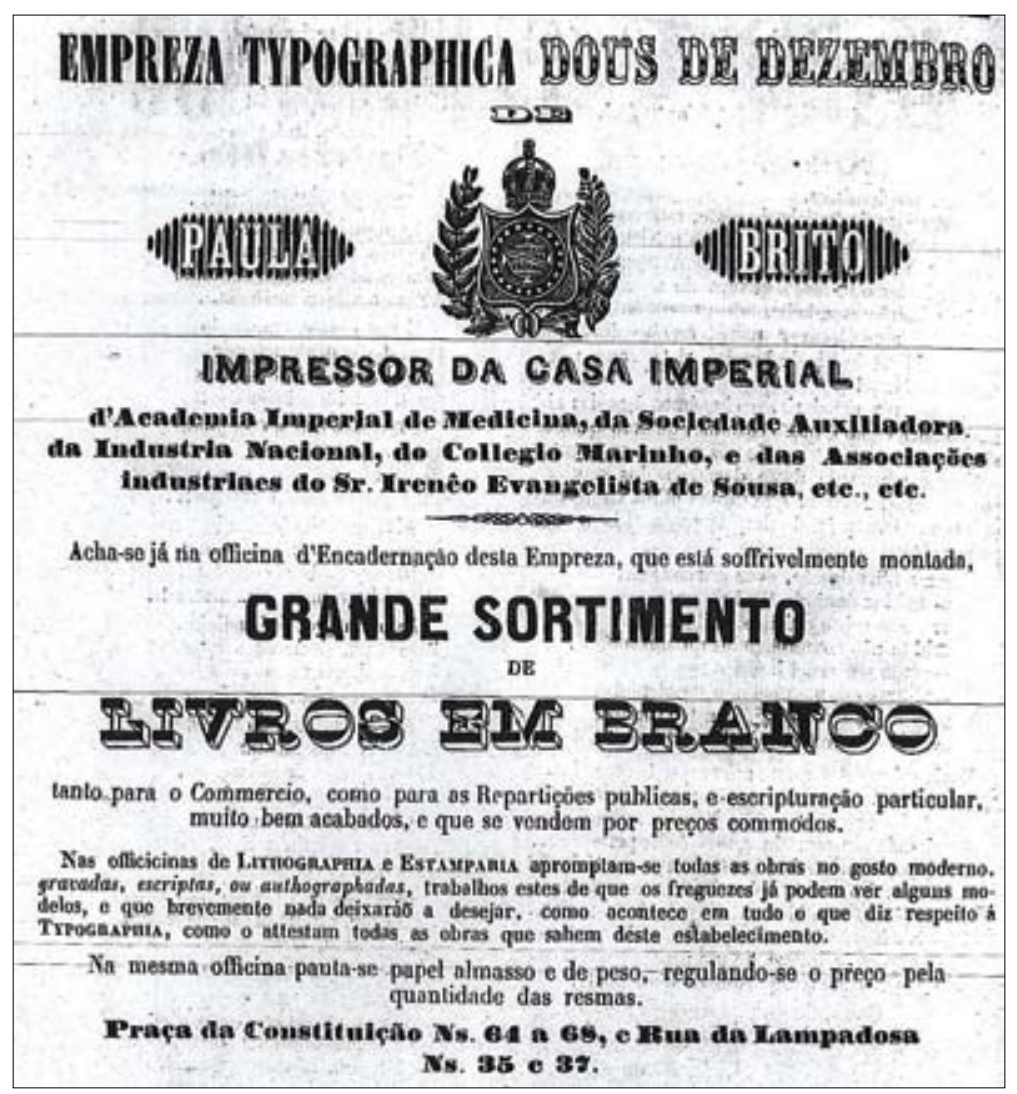

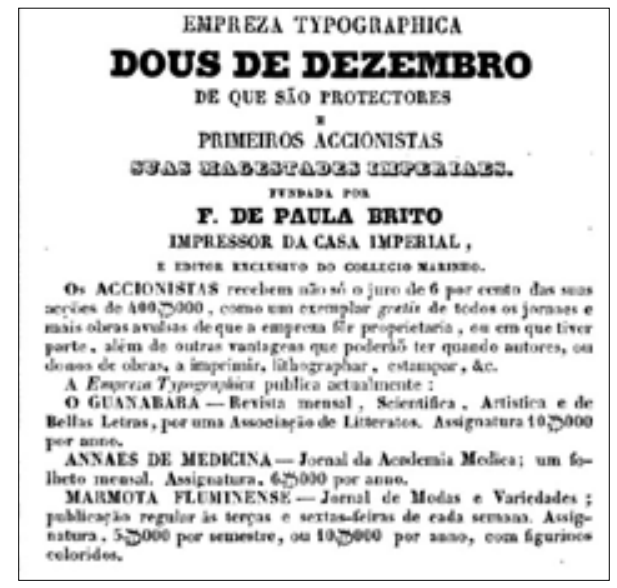

Figura 14. Anúncio da Empresa Dous de Dezembro no Almanaque Laemmert de 1853.

Figura 15. Anúncio da Empresa Tipográfica Dous de Dezembro na Marmota em 1853. 
- O Carioca: Jornal Político, Amigo da Igualdade e da Lei - Tipografia Fluminense de Brito \& C., 1833-1834.

- O Atlante - fundado por Justiniano José da Rocha, circulou de maio a agosto de 1836, impresso na Tipografia Imparcial de Brito, sua epígrafe citava Luís XII: "Les lois sont les souveraines des souverains".

- Liga Americana: Jornal Político - Tipografia Imparcial de F. de Paula Brito, outubro de 1839 a fevereiro de 1840; era redigido por Aureliano de Sousa e Oliveira Coutinho e Manuel Odorico Mendes, tendo sido um dos primeiros periódicos americanistas do Brasil.

- O Propugnador da Maioridade - Tipografia Imparcial de Brito, maio a julho de 1840.

- O Homem do Povo - Imprensa Imparcial de Brito, 1840.

- O Eco do Rio: Jornal Político e Literário - Tipografia Imperial de P. Brito, em circulação entre agosto de 1843 e março de 1844 e redigido por Tomás José Pinto de Siqueira.

Segundo Gondim, Paula Brito criou a Biblioteca Guanabarense em 1849. Tratava-se de uma coleção de obras - editadas pela então Empresa Tipográfica Dous de Dezembro - que era comercializada juntamente com a revista mensal Guanabara, que, como se sabe, é uma das principais publicações associadas ao início do romantismo no Brasil. Alguns títulos dessa coleção foram: o romance Rosa (1849) e o drama Cobé (1852), de Joaquim Manuel de Macedo; a comédia arqueológica A Estátua Amazônica (1851), de Manuel de Araújo Porto-Alegre; Excertos das Memórias e Viagens do Coronel Bonifácio do Amarante (1852), de Tibúrcio do Amarante (pseudônimo de Porto-Alegre); o drama Amador Bueno ou a Fidelidade Paulistana (1855), de Joaquim Norberto de Sousa e Silva; e a tragédia O Cavaleiro Teutônico ou a Freira de Marienburg (1855), de Antônio Gonçalves Teixeira e Sousa.

No que se refere à produção livreira, Gondim emite o seguinte juízo sobre o tipógrafo:

Paula Brito, que havia editado, em 1843, o primeiro romance brasileiro, O Filho do Pescador, de Teixeira e Sousa, formaria, com os nomes mais ilustres da nossa literatura, a mais extensa e valiosa série de primeiras edições, de que se tem notícia, publicada no período que vai de 1831, quando iniciou sua carreira de editor, até o fim de seus dias, em 1861, trabalho de trinta anos, árduo, mas rico de produtividade ${ }^{49}$.

Sem pretensões de originalidade bibliográfica, pois parece conclusa a pesquisa nesse setor, apresenta-se, a seguir, uma relação de obras editadas por Paula Brito, a partir da pesquisa de Gondin, que se tem seguido nesta unidade da dissertação. Como se viu, anteriormente foram examinados os biógrafos precedentes. Assim, com o propósito de caracterizar o perfil editorial do impressor e de examinar o discurso biográfico existente sobre ele, opera-se essa incorporação dos dados de Gondin, assimilados como suporte para o argumento geral da dissertação:

49. Eunice Ribeiro Gondim, op. cit., p. 45. 
- Prólogo Dramático, de Manuel de Araújo Porto-Alegre com música de Cândido José da Silva, publicado 1837 (Tipografia Imparcial de Brito). O prólogo foi representado no Teatro Constitucional Fluminense em 2 de dezembro de 1837.

- A primeira edição da tragédia Antônio José ou o Poeta e a Inquisição, de Gonçalves de Magalhães, em 1839 (Tip. Imparcial de F. de Paula Brito). Ao que se sabe, esta foi uma das primeiras peças teatrais concebida por um brasileiro que também abordava assuntos nacionais. Estreou no Teatro São Pedro de Alcântara em março de 1838 com a companhia de João Caetano.

- A primeira edição de Cânticos Líricos, de Antônio Gonçalves Teixeira e Sousa, em 1841 (Tip. Imparcial de F. de P. Brito). Trata-se da primeira obra poética do autor reunida em livro (dois volumes, o segundo saiu em 1842).

- Em 1843 Brito edita o primeiro romance brasileiro, O Filho do Pescador, de Antônio Gonçalves Teixeira e Sousa.

- Um Roubo na Pavuna, de Luís da Silva Azambuja Susano, em 1843. Embora a obra tenha sido impressa como anônima, sabe-se que seu autor - posteriormente reconhecido - produziu com este título o primeiro romance histórico do país.

- Em 1845, Paula Brito publica a segunda edição da obra de Nísia Floresta Brasileira Augusta, Conselhos à Minha Filha.

- Os Irmãos das Almas, de Martins Pena, em 1847. A segunda edição é de 1852. A comédia esteve em cartaz no Teatro São Pedro de Alcântara em novembro de 1844.

- O Caixeiro da Taberna, de Martins Pena, em 1847. A segunda edição da comédia é datada de 1852, também publicada por Paula Brito. A peça foi encenada no Teatro São Pedro de Alcântara em novembro de 1845.

- Quem Casa Quer Casa, de Martins Pena, em 1847. Igualmente, Brito foi responsável pela segunda edição em 1852. A comédia esteve em cartaz no Teatro São Pedro de Alcântara em dezembro de 1845.

- A Estátua Amazônica, comédia arqueológica de Manuel de Araújo Porto-Alegre, em 1848.

- Rosa, romance de Joaquim Manuel de Macedo lançado por Paula Brito na Biblioteca Guanabarense, em 1849.

- Indice Cronológico dos Fatos Mais Notáveis da História do Brasil (1500-1849), de Agostinho Marques Perdigão Malheiros, em 1850.

- Nênia à Morte Sentidíssima do Sereníssimo Príncipe Imperial Senhor Dom Pedro, de Gonçalves Dias, em 1850.

- Últimos Cantos, de Gonçalves Dias, em 1851.

- Cobé, drama em verso heróico de Joaquim Manuel de Macedo, publicado por Paula Brito para a Biblioteca Guanabarense em 1852.

- A Missão Especial de Outubro de 1844 a Outubro de 1846, de Miguel Calmon Du Pin e Almeida (Marquês de Abrantes), em 1853. Na obra, o autor relata sua missão diplomática ligada à independência da Província Cisplatina e do Paraguai. 
- Leituras em Verso ou Poesias Seletas para Uso da Infância de Ambos os Sexos, de Gonçalves Dias, em 1853.

- Vicentina, romance de Joaquim Manuel de Macedo, em 1853.

- Fisiologia das Paixões e Afecções, de Alexandre José de Melo Morais, 1854.

- Épicos Brasileiros, de Francisco Adolfo de Varnhagen, em 1855. Primeira edição brasileira (publicada em Portugal em 1843).

- Os Portugueses Perante o Mundo, de Alexandre José de Melo Morais, em 1856.

- As Primaveras, de Casimiro de Abreu, 1859.

- O Prestígio da Lei, drama lírico de Manuel de Araújo Porto-Alegre, com música de Francisco Manuel da Silva, em 1859.

- Segunda edição do romance Maria ou a Menina Roubada, de Teixeira e Sousa, em 1859 (é considerada a primeira, a publicação feita na Marmota Fluminense, em 1852).

- A Noite de S. João, comédia lírica de José de Alencar com música de Elias Álvares Lobo, em 1860. A ópera foi representada no Teatro São Pedro de Alcântara em dezembro do mesmo ano, sob a regência de Carlos Gomes.

- Luxo e Vaidade, comédia de Joaquim Manuel de Macedo, em 1861. Foi representada no Ginásio Dramático em setembro do mesmo ano.

- Queda Que as Mulheres Têm pelos Tolos, tradução de Machado de Assis, em 1861.

- Desencantos: Fantasia Dramática, de Machado de Assis, em 1861.

- Paula Brito publica os três primeiros volumes de Pequeno Panorama, de Moreira de Azevedo, em 1861. Os dois volumes finais foram editados em outra tipografia em 1862 e 1867.

Ainda, citam-se aqui algumas obras anunciadas na Marmota, em uma "lista do que se vende na rua do Cano - 44, nova tipografia e loja de Paula Brito, e praça da Constituição, 64", complementadas com a data da primeira publicaçãa ${ }^{50}$ :

- Olgiato, tragédia em cinco atos de Domingos José de Gonçalves de Magalhães, publicada em 1841. Foi representada no Teatro São Pedro de Alcântara em setembro de 1839.

- O Juiz de Paz na Roça, de Martins Pena, a primeira edição data de 1842. Essa comédia esteve em cartaz no Teatro São Pedro de Alcântara em outubro de 1838. A segunda e a terceira edições da obra, publicadas em 1843 e 1855, também saíram das oficinas de Paula Brito.

- A Família e a Festa na Roça, também de Martins Pena, de 1842. Comédia em um ato que foi representada no Teatro São Pedro de Alcântara em setembro de 1840. A segunda edição da peça, de 1853, foi igualmente publicada por Paula Brito. 
- Otelo ou O Mouro de Veneza, tragédia de Jean François Ducis traduzida por Domingos José Gonçalves de Magalhães, publicada em 1842.

- Os Três Dias de um Noivado, de Teixeira e Sousa, editada em 1844.

- O Judas em Sábado de Aleluia, de Martins Pena, em 1846. A comédia foi encenada no Teatro São Pedro de Alcântara em setembro de 1844. A segunda edição da obra foi impressa por Paula Brito em 1852.

- O Diletante, de Martins Pena, em 1846. Peça representada no Teatro São Pedro de Alcântara em fevereiro de 1845.

- A Independência do Brasil, poema épico de Teixeira e Sousa, publicado em 1847, em dois volumes.

- História e Descrição da Febre Amarela Epidêmica que Grassou no Rio de Janeiro em 1850, de José Pereira Rego, Barão de Lavradio, em 1851.

- Os Hinos de Minha Alma, de Constantino José Gomes de Sousa, em 1851.

- Fábia: Tragédia Herói-cômica em Três Atos, por Francisco Palha, 1852.

- Vocabulário Brasileiro para Servir de Complemento aos Dicionários da Língua Portuguesa, de Braz da Costa Rubim, editado em 1853.

- Ensaio Corográfico do Império do Brasil, de Alexandre José de Melo Morais e Ignácio Acciolli de Cerqueira e Silva, em 1853.

- O Noviço, de Martins Pena, em 1853. Comédia representada no Teatro São Pedro de Alcântara em agosto de 1845.

- A Carteira de Meu Tio, de Joaquim Manuel de Macedo, em 1855.

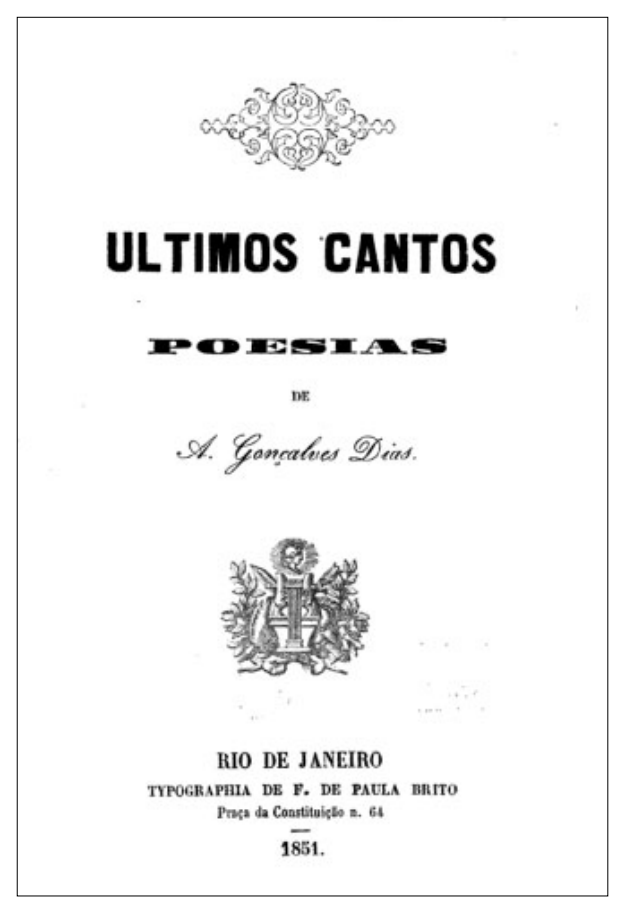

Figura 16. A obra Últimos Cantos, de Gonçalves Dias, foi editada pela Tipografia de F. de Paula Brito em 1851.

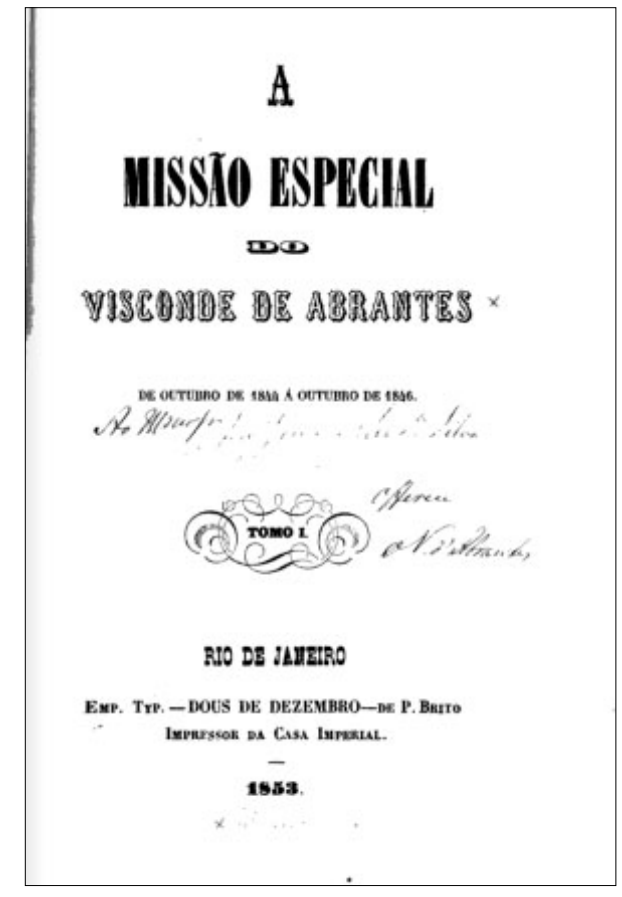

Figura 17. A Missão Especial do Visconde de Abrantes foi publicada pela Empresa Tipográfica Dous de Dezembro em 1853. 
- O Forasteiro, romance de Joaquim Manuel de Macedo, em 1855.

- Amador Bueno ou a Fidelidade Paulistana, drama histórico de Joaquim Norberto de Sousa Silva editado para a Biblioteca Guanabarense, em 1855.

- O Cavaleiro Teutônico ou a Freira de Marienburg, obra de Teixeira e Sousa para a Biblioteca Guanabarense, publicada em 1855.

- As Consolações, de Joana de Noronha, em 1856.

- A Confederação dos Tamoios, poema de Domingos José Gonçalves de Magalhães dedicado a Pedro II, em 1856. A primeira edição foi uma tiragem especial, em 1857 foi publicada a edição comum.

- O Fantasma Branco, ópera em três atos de Joaquim Manuel de Macedo, com música de Dionísio Vega, em 1856. A ópera esteve em cartaz no Teatro São Pedro de Alcântara em junho de 1851.

- A Fatalidade de Dous Jovens, romance de Teixeira e Sousa, em 1856.

- Cantos da Mocidade, obra de estréia da poetisa Beatriz Francisca de Assis Brandão, em 1856.

- A Poesia do Amor, de Antônio José de Araújo, em 1857.

- A sétima edição do poema O Uraguai, de Basílio da Gama, em 1858 (considera-se como sexta a que Paula Brito divulgou em seu periódico Marmota Fluminense, em 1855).

- O Primo da Califórnia, ópera de Joaquim Manuel de Macedo, em 1858. Foi encenada no Ginásio Dramático em abril de 1855.

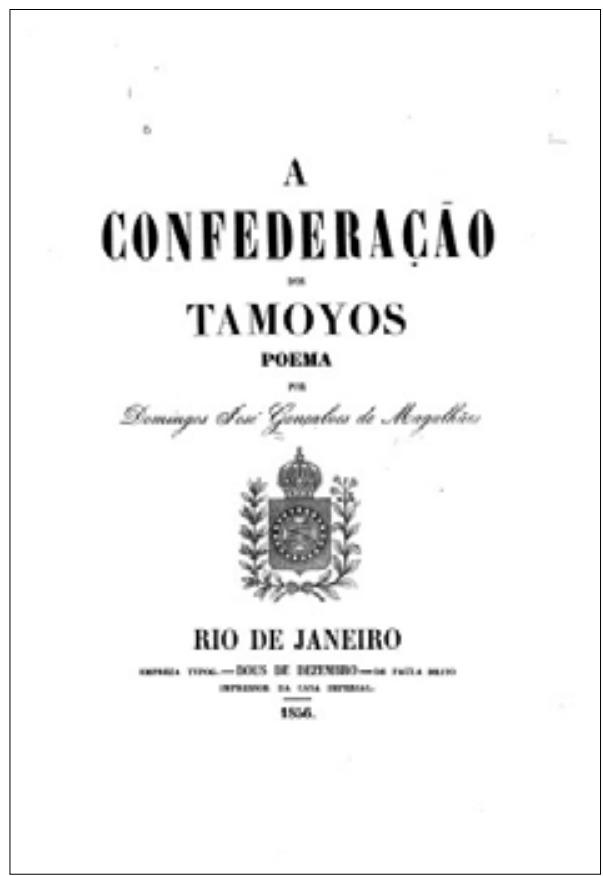

Figura 18. A Confederação dos Tamoios de Gonçalves de Magalhães publicada pela Tipografia Dous de Dezembro em 1856.

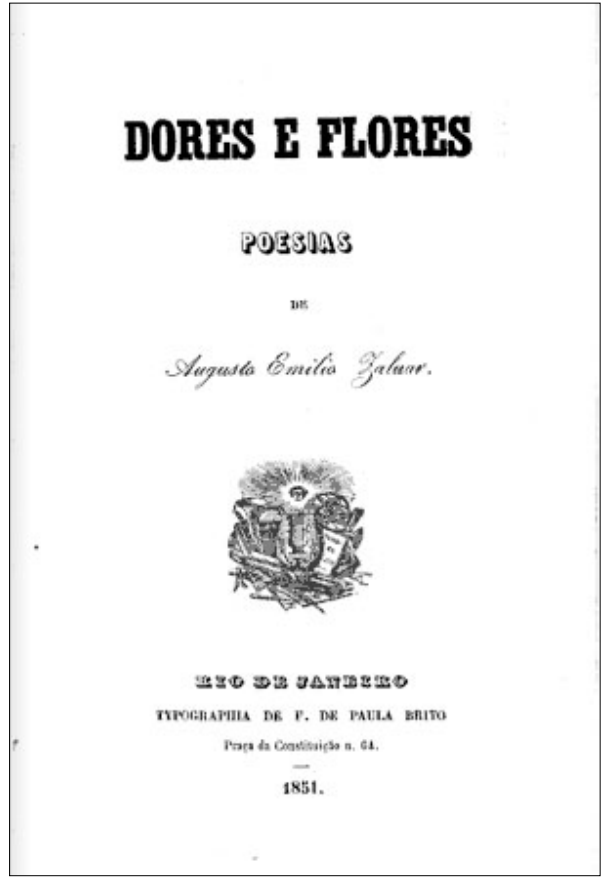

Figura 19. Dores e Flores, de Augusto Emílio Zaluar, foi editada pela Tipografia de F. de Paula Brito em 1851. 
- A Questão de Dinheiro, comédia de Alexandre Dumas Filho traduzida por Justiniano José da Rocha, em 1858.

Do inventário elaborado por Gondim de material não-periódico publicado por Paula Brito, é possível, igualmente, apontar quatro elementos predominantes: dramas, publicação de teses e dissertações, textos literários e obras históricas. Dentro desse grupo, as peças teatrais são maioria, consistindo em $37 \%$; seguidas pelas teses acadêmicas, com $29 \%$; e então as obras literárias, com $24,5 \%$, e sobre história, 9,5\%. Do mesmo modo, o tipógrafo fez rodar em suas prensas textos de diversos tipos, relatórios os mais variados, estatutos de diversas entidades, discursos, textos de divulgação jurídica e até algumas obras médicas.

Gondim aponta também duas iniciativas de Paula Brito, datadas de 1859, que foram bastante significativas. A primeira foi a criação da folha semanal Arquivo Municipal, destinada à publicação dos atos oficiais da Ilustríssima Câmara Municipal (atual Câmara dos Vereadores) ${ }^{51}$. A segunda foi a publicação da Biblioteca das Senhoras, uma coletânea de oito romances reunida em dois volumes destinada ao público feminino, principalmente as para jovens estudantes ${ }^{52}$.

\section{A Petalógica}

Eunice Ribeiro Gondim lembra que Paula Brito "com seu precioso dom de fazer amigos conseguiu reunir na sua pequena loja do Largo do Rossio, durante trinta anos, as figuras mais representativas das letras, das artes, da política e da sociedade"53. A tipografia havia se tornado ponto de encontro de grandes personagens da cena fluminense, que para lá se dirigiam para debater os mais variados assuntos. O grupo denominou-se Sociedade Petalógica, nome derivado de peta, mentira.

Na Marmota Fluminense saíram algumas quadrinhas sobre a agremiação, como a seguinte:

\section{FACÉCIAS}

Neste mundo em que se vive

Ora rindo, ora chorando,

Pouco não faz quem procura

"Ser útil, inda brincando"

(Da Redação)

O QUE HÁ DE NOVO? - é pergunta

Que faz qualquer, pra saber

Das cousas, sem o trabalho

De as indagar, nem de as ver.

51. Eunice Ribeiro Gondim, op. cit., p. 49.

52. Idem, ib., p. 51.

53. Idem, ib., p. 59. 


\author{
Por causa do - QUE HÁ DE NOvO \\ Arranjou-se a sociedade, \\ Que, tudo o que lhe parece \\ Vai dando por novidade. \\ (Com bem raras exceções \\ Também vemos hoje em dia \\ Pouca gente que não tenha \\ Lugar na - PETALOGIA)! ${ }^{54}$
}

Machado de Assis em muitos de seus textos recordava a Petalógica. Em uma de suas crônicas para um jornal diário, define o grupo da seguinte maneira:

Este livro é uma recordação, - é a recordação da Petalógica dos primeiros tempos, a Petalógica de Paula Brito - o café Procópio de certa época - onde ia toda a gente, os políticos, os poetas, os dramaturgos, os artistas, os viajantes, os simples amadores, amigos e curiosos - onde se conversava de tudo - desde a retirada de um ministro até a pirueta da dançarina da moda; onde se discutia tudo, desde o dó do peito do Tamberlick até os discursos do marquês de Paraná, verdadeiro campo neutro onde o estreante das letras se encontrava com o conselheiro, onde o cantor italiano dialogava com ex-ministros. [...] Cada qual tinha a sua família em casa; aquela [Petalógica] era a família da rua - le ménage em ville - entrar ali era tomar parte na mesma ceia (a ceia vem aqui por metáfora) porque o Licurgo daquela república assim o entendia, e assim o entendiam todos quantos transpunham os umbrais. Queríeis saber do último acontecimento parlamentar? Era ir à Petalógica. Da nova ópera italiana? Do novo livro publicado? Do último baile do E...? Da última peça de Macedo ou Alencar? Do estado da praça? Dos boatos de qualquer espécie? Não se precisava ir mais longe, era ir à Petalógica ${ }^{55}$.

\title{
Conclusão de Gondim
}

A autora chama de "bela e comovente" a figura de Paula Brito ${ }^{56}$. Afirma que por muitos anos o tipógrafo esteve quase esquecido, mas que seu nome nunca poderá ser olvidado, se não por outros motivos, ao menos por conta de sua contribuição para o desenvolvimento editorial do Brasil. Sem dúvida, Vida e Obra de Paula Brito: Iniciador do Movimento Editorial no Rio de Janeiro (1809-1861) é um trabalho competente. Em que pese seu valor e sua condição pioneira, talvez pudesse ser criticado pelo excesso de adesão da voz dissertativa ao objeto de estudo. Se fosse necessário operar um juízo crítico sobre esse admirável trabalho, talvez se pudesse pensar na hipótese de que a sua autoria se estabelece a partir de pressupostos um tanto próximos aos do próprio biografado. O maior indicador

54. Marmota Fluminense, 17 jun. 1856.

55. Diário do Rio de Janeiro, 3 jan. 1865, em Machado de Assis, Crônicas, vol. 2, pp. 262-263.

56. Eunice Ribeiro Gondim, op. cit., p. 69. 
dessa hipótese seria o conceito de biografia como elogio, e não como exercício crítico e interpretativo. Por outro lado, deve-se destacar a precisão dos dados e o útil levantamento bibliográfico apresentado. Podendo ser entendido como ponto de chegada de uma longa tradição biográfica, o esforço de Gondin é meritório e digno de apreço, porque, de fato, possibilita a inclusão crítica de Paulo Brito no discurso atual sobre a história da editoração no Brasil.

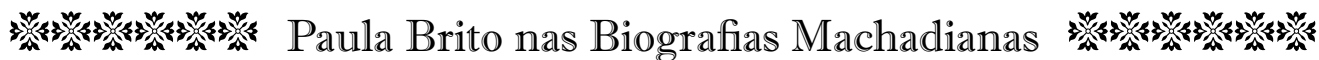

Francisco de Paula Brito é freqüentemente mencionado nas biografias dedicadas a divulgar a vida de Machado de Assis, especialmente naquelas que oferecem uma idéia mais palpável de sua juventude. Alfredo Pujol talvez tenha sido o primeiro biógrafo machadiano a mencionar a influência de Paula Brito na história do escritor. Em sua obra de 1917, Machado de Assis: Curso Literário em Sete Conferências na Sociedade de Cultura Artística de São Paulo, informa que a grande atração da adolescência de Joaquim Maria foi a loja de livros de Paula Brito, onde encontrou amizade e proteçã $0^{57}$. O autor busca oferecer aos seus leitores um esboço do tipógrafo utilizando as seguintes expressões: "curioso mestiço, de um ardente patriotismo e de uma delicada sensibilidade" 58 e “jornalista originalíssimo" ${ }^{9}$. Retomando o já estabelecido lugar-comum de recriar a loja de Paula Brito como uma espécie de academia informal, Pujol também lembra que o estabelecimento da praça da Constituição era ponto de encontro de políticos e escritores de todos os tipos e que circulou, à época, o boato de que o soneto "Formosa, Qual Pincel em Tela Fina”, de Maciel Monteiro, teria sido escrito nos balcões da loja ${ }^{60}$.

Outra tópica retomada nesse texto é a de que, apesar de sua limitada condição financeira, Paula Brito sempre procurou auxiliar os amigos que se mostrassem mais carentes. De acordo com Pujol, para levantar mais fundos Brito:

procurava explorar da maneira mais proveitosa a sua veia poética, quase sempre banal: escrevia versos para lenços, livros de sortes para as festas dos santos populares e inscrições poéticas "muito tocantes e sentimentais", como diziam os anúncios, para enterros, missas e catacumbas... ${ }^{61}$.

Pujol, desse modo, assente com Melo Morais Filho, que enquadra Paula Brito como "poeta de estreito vôo"62, e lembra que para garantir seu sustento e a prosperidade de seu negócio, o tipógrafo

57. Alfredo Pujol, Machado de Assis: Curso Literário em Sete Conferências na Sociedade de Cultura Artística de São Paulo, p. 5.

58. Idem, $i b$.

59. Idem, ib., p. 6.

60. Antônio Peregrino Maciel Monteiro (1804-1868), barão de Itamaracá, foi médico, poeta, diplomata brasileiro e político, chegou a atuar como deputado e ministro.

61. Alfredo Pujol, op. cit., p. 7.

62. Melo Morais Filho, op. cit., p. 16. 
não podia se valer apenas da venda das obras que publicava e da circulação de seus periódicos.

Para Elói Pontes, Paula Brito é um "espírito acolhedor". Chama-o ainda de "mulato, inteligente e astuto, duma estranha modéstia" ${ }^{\prime 3}$. Em seu entender, Brito reúne em sua loja tudo o que há de mais seleto na literatura de seu tempo. E, segundo Pontes, com a intenção de movimentar ainda mais esse espaço o tipógrafo teria fundado a Petalógica. Tampouco ele deixa de mencionar que Brito sempre publicava os trabalhos de poetas anônimos e autores iniciantes em suas revistas, além de ter oferecido ao jovem Machado o cargo de revisor de provas tipográficas.

Antes mesmo de mencionar a influência do tipógrafo na vida de Machado, a próxima biografia examinada, de Gondin da Fonseca, informa o patamar em que se encontravam as artes gráficas no período e faz a seguinte consideração:

Ampliada a Revolução Industrial, apareceram os editores em todos os grandes centros e também no Rio de Janeiro. Gregório de Matos nunca teve editor. Nem bastante depois dele, Cláudio Manoel da Costa, João Francisco Lisboa e José Bonifácio. Machado de Assis encontrou-os desde o seu primeiro livro ${ }^{64}$.

Especificamente sobre a relação entre Machado e seu primeiro editor, o autor considera que: "Nem teve necessidade de que alguém lho apresentasse. O jornalista era muito católico, não perdia missa cantada, nem sermão, dava-se com toda a gente" ${ }^{15}$. Não se conhece a origem da não necessidade de apresentação, mas o que se pode depreender é a intenção de registrar Paula Brito como uma personalidade marcadamente amigável e fraternal.

Gondin da Fonseca cita igualmente os periódicos que Brito dirigiu, os encontros que ocorriam em sua loja, as dificuldades financeiras que enfrentava e até mesmo menciona o fechamento de sua empresa em 1857. Registra ainda que: "além de católico e admirador do jovem D. Pedro II, era Paula Brito nacionalista e até jacobino. Quando um jornaleco satírico de Lisboa, Asmodeu, atacou a nossa terra, Paula Brito entrou de sola em cima dele apesar da força da colônia lusa" ${ }^{66}$.

Outra mostra de patriotismo a que Gondin da Fonseca alude ocorreu quando surgiram rumores de que a irmã de Pedro II, D. Maria II, rainha de Portugal, estaria interessada em casar seu filho com a com a princesa brasileira. Ao que se sabe, Paula Brito foi uma das vozes que combateu publicamente essa hipótese, condenando, inclusive, os demais órgãos da imprensa diária que não o fizeram.

Em Machado de Assis e o Hipopótamo, Gondin da Fonseca além de mencionar um amigo comum entre Machado de Assis e o tipógrafo, o padre-mestre Antônio José da Silveira Sarmento, registra igualmente o círculo literário encarnado na Petalógica e sua influência sobre o jovem escritor ${ }^{67}$.

63. Elói Pontes, Machado de Assis, p. 12.

64. Gondin da Fonseca, Machado de Assis e o Hipopótamo, p. 77.

65. Idem, ib., p. 87.

66. Idem, ib., p. 89.

67. O poema de Machado "A Morte no Calvário" é dedicado ao padre Silveira Sarmento, publicado em A Marmota, n. 939, 2 abr. 1858. Ao que se sabe, o sacerdote foi o professor de latim e francês de Machado de Assis. 
Como se sabe, a biografia escrita por Lúcia Miguel Pereira teve várias edições ${ }^{68}$. Nela, o que deveria ser fato ou hipótese torna-se quase que parte de um romance. Suas primeiras palavras sobre Paula Brito são:

Paula Brito, também mulato e pobre, começara a vida como tipógrafo na Tipografia Plancher, e, em 1831, estabelecera-se com oficina própria.

Dentro em breve, tornava-se a sua casa o centro da vida literária. Tão bom homem quanto mau poeta, generoso, serviçal, sempre pronto a auxiliar os escritores com a sua bolsa e com grandiloqüentes elogios na Marmota, por ele dirigida e editada, Francisco de Paula Brito foi realmente um grande animador.

Nos balcões da sua loja debruçavam-se para conversar todos os intelectuais do momento.

E o jovem Machado de Assis, feio e tímido, rondava-lhe a porta, faminto de alimento para o espírito, levado pela irresistível vocação literária.

Ali ficava, a admirar a gente que entrava, gente feliz que podia comprar e escrever $\operatorname{livros}^{69}$

Lúcia Miguel Pereira, como fez Gondin da Fonseca, tenta recompor o primeiro encontro entre Joaquim Maria e Paula Brito. Dada a escassez de informações sobre esse evento, o que se pode imaginar é que o jovem foi logo incorporado ao grupo do tipógrafo:

[...] ei-lo de novo, obstinado e irresoluto, a passar pela porta do Paula Brito, sem coragem de entrar.

[...] deve ter sido, logo de saída, bem acolhido pela bondade ativa do editor. E começou a freqüentar-lhe ativamente a livraria, onde encontrou o ponto de apoio para o início da sua carreira literária ${ }^{70}$.

E Machado de Assis teria se identificado tanto com o ambiente da loja de Paula Brito que, por isso, teria sido contratado como revisor de provas da tipografia, em 1858. No entanto, a autora levanta a hipótese de que a Sociedade Petalógica poderia ter sido uma influência negativa sobre Machado, pois defende que seus membros eram, em sua maioria, "indigentes intelectuais" de mau gosto "verdadeiramente incrível" loja de Paula Brito foram importantes, pois teriam funcionado como uma espécie de segunda família para o jovem ${ }^{72}$.

Em seu A Juventude de Machado de Assis, Jean-Michel Massa busca resgatar a importância de Paula Brito, de sua loja e de seu círculo literário na vida do escritor em formação. Sem também fugir

68. Lúcia Miguel Pereira, Machado de Assis: Estudo Crítico e Biográfico, 1939.

69. Idem, ib., p. 47.

70. Idem, ib., p. 49.

71. Idem, ib., p. 62.

72. Idem, ib., pp. 64-65. 
ao modelo discursivo estabelecido, Massa inicialmente descreve o tipógrafo como "mulato, saído de um meio bastante humilde de artesãos" e como "homem que se fizera por si mesmo"73. Adiciona, ainda, ao rótulo de menino pobre, a idéia de que Brito era também "patriota ardente", pois admirava Pedro II e freqüentemente lhe consagrava vibrantes poemas. Essa devoção, segundo o autor, rendeu preciosos frutos, pois o soberano "salvou em diversas oportunidades Paula Brito da falência e muito particularmente em 1857, concedendo-lhe uma subvenção, a fim de ressarcir indiretamente seus credores portugueses"74. Não se sabe de fato quais seriam as "diversas oportunidades", mas é certo que Suas Majestades eram acionistas da Empresa Tipográfica Dous de Dezembro, que decretou falência em 1857.

Massa tenta enfatizar a faceta de editor de Paula Brito, como incentivador da cultura brasileira. Sobre isso, comenta: "Paula Brito era um idealista e foi um benefício para a literatura brasileira o fato de que a ele tenha faltado realismo; sem um grão de fantasia ele jamais teria a audácia de acolher e lançar tantos poetas e escritores"75. E completa tal idéia, comentando que essa era uma característica que o distinguia de B. L. Garnier, “o bom ladrão Garnier”, que, mais realista, era menos desinteressado.

Raimundo Magalhães Júnior, no capítulo "Nos Tempos da Petalógica” de sua extensa biografia, pouco se detém na construção da figura do tipógrafo, apenas informa que o jovem Machado pertencia ao círculo de seus amigos mais íntimos e busca aprofundar-se nas inter-relações entre os membros da Petalógica e seu biografado ${ }^{76}$.

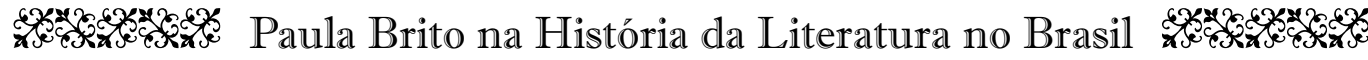

Em sua História da Literatura Brasileira, no capítulo "Os Próceres do Romantismo", José Veríssimo dedicou algumas linhas para expor quem foi Francisco de Paula Brito e qual foi sua contribuição para as letras do país:

De quase nenhumas letras, mas inteligente e curioso, despertou-se-lhe o gosto por aquelas e pelos seus cultores no trato de umas e outros, no exercício de seu ofício de tipógrafo. [...] Como fosse muito caroável de literatos, a quem com periódicos que fundou, como a Marmota (1849-1861), oferecia a satisfação de se verem publicados e louvados, a sua loja, no antigo largo do Rossio, tornou-se o prazo dado da mocidade literária do tempo, e, como era igualmente patriota ardente e chefe político de bairro, freqüentavam-no também homens públicos notáveis, doutores e outros letrados. Por ser a sua loja um centro de notícias, palestras e novidades da vida urbana que não seriam sempre de extrema veracidade e antes facilmente mentirosas, deu-lhe o povo a alcunha de "A Petalógica". Foram seus habituados todos os nossos primeiros e ainda muitos dos segundos românticos, de todas as graduações. Desse comércio com letrados, a inteligência

73. Jean-Michel Massa, A Juventude de Machado de Assis, p. 82.

74. Idem, ib., p. 83.

75. Idem, ib.

76. R. Magalhães Júnior, Vida e Obra de Machado de Assis, vol. 1, p. 56. 
aberta e pronta de mestiço de Paula Brito tirou o melhor proveito. Ele também se fez escritor e poeta ${ }^{77}$.

Interessante notar que na versão de Veríssimo, era chamada Petalógica não o grupo de literatos, mas a própria loja de Paula Brito. E, segundo esse registro, tal nome não teria partido dos próprios freqüentadores do local, mas do povo em geral. Mesmo chamando de medíocres as inclinações literárias de Brito, o autor as reconhece e as atribui ao ambiente instalado em sua tipografia. Esse comentário não chega a ser totalmente adequado, uma vez que se sabe que o tipógrafo tem trabalhos assinados desde a década de 1830, antes mesmo da consolidação da roda literária em sua loja.

Afrânio Coutinho, em A Literatura no Brasil, também enquadra Paula Brito como autor romântico, pertencente ao que ele chama de segundo grupo, que, como é amplamente sabido, tem como outros representantes Joaquim Manuel de Macedo, Antônio Gonçalves Dias e Bernardo Joaquim da Silva Guimarães ${ }^{78}$. Lembra o autor que, nessa segunda fase do romantismo, Paula Brito foi figura constante, principalmente por conta dos encontros diários de literatos que aconteciam em sua loja e pelo papel que o editor exercia como protetor dos jovens iniciados nas letras ${ }^{79}$.

Brito é pouco mencionado em Formação da Literatura Brasileira, de Antonio Candido. A primeira das escassas alusões a seu nome trata de trecho sobre Teixeira e Sousa ${ }^{80}$. Depois, fala-se que "outro tradutor foi Paula Brito, de importante função ancilar na literatura romântica, livreiro, editor, centro da Sociedade Petalógica" ${ }^{\text {"1 }}$. Adiante, no mesmo texto, novamente Teixeira e Sousa é abordado, e registra-se que: "como romancista, os poucos que lhe deram importância foram, excetuando-se Santiago Nunes Ribeiro, gente secundária: Paula Brito [... $]^{82}$.

Nelson Werneck Sodré procura lembrar Paula Brito como o editor de obras importantes na história da literatura nacional. Primeiro, ele é citado como o editor de O Filho do Pescador, primeiro romance brasileiro; a seguir é mencionado como tendo levado a público os Últimos Cantos de Gonçalves Dias, dois títulos de Macedo - O Forasteiro e A Carteira de Meu Tio -, As Fatalidades de Dous Jovens de Teixeira e Sousa e A Confederação dos Tamoios de Gonçalves de Magalhães ${ }^{83}$. Sodré também se propõe a traça um sucinto esboço dessa figura:

[...] Francisco de Paula Brito, político, jornalista, poeta, editor, mestiço de talento que deu às atividades literárias do seu tempo todo o estímulo e que teve um papel importante em quase todos os acontecimentos das letras na sua época. [...] tipógrafo que se tornou literato e protetor de homens de letras, acabando a vida pobre, embora não esquecido, depois de ter, no mesquinho ambiente da época, dado à atividade editorial o impulso máximo a que ela se poderia sujeitar então ${ }^{84}$.

77. José Veríssimo, História da Literatura Brasileira, vol. 3, 1963, p. 159.

78. Afrânio Coutinho (org.), A Literatura no Brasil, 1955, vol. I, tomo 2, p. 588.

79. Idem, ib., p. 649.

80. Antonio Candido, Formação da Literatura Brasileira: Momentos Decisivos, p. 75.

81. Idem, ib., p. 121.

82. Idem, ib., p. 126.

83. Nelson Werneck Sodré, História da Literatura Brasileira, pp. 215-216.

84. Idem, ib., p. 220. 
$\mathrm{O}$ autor ainda guarda um trecho de suas notas de capítulo para apresentar uma breve biografia de Brito. Nela, são descritos os poucos recursos da infância, a profissão de tipógrafo, os jornais por ele fundados, a loja freqüentada pelos grandes nomes da literatura de seu tempo, o trabalho como editor de jovens talentos e suas poesias postumamente publicadas que, segundo Sodré, "carecem de expressão"85.

Seguindo a mesma linha de Sodré, Brito Broca afirma que Paula Brito foi o primeiro editor brasileiro de obras literárias:

[...] enquanto de Paula Brito, está bem patente que procurava lançar por sua conta e risco os novos da época (no despontar do nosso Romantismo não havia, aliás, "velha geração"), o que nos leva a dar-lhe o título de nosso primeiro editor de obras literárias. Curiosa, simpática e digna da admiração da posteridade, era a figura desse mulato fluminense de origem modesta e pele escura, indissoluvelmente ligada à vida de vários escritores românticos e sobretudo à glória de Machado de Assis ${ }^{86}$.

Broca nomeia abertamente Moreira de Azevedo como fonte de seus dados sobre o tipógrafo e ainda ressalta um aspecto pouco explorado de sua biografia, o de homem empreendedor bastante dedicado às suas iniciativas comerciais ${ }^{87}$. Afinal, ele chegou a dirigir vários pontos comerciais onde oferecia seus serviços gráficos, além de produzir e distribuir suas próprias folhas - A Mulher do Simplício e posteriormente a Marmota, em suas três fases. O autor também não se esquece de mencionar que houve muito empenho da parte do tipógrafo para apoiar os que se iniciavam na literatura, por isso, resgata um epíteto empregado por José Veríssimo para definir Paula Brito, o de mecenas pobre ${ }^{88}$. Sobre a veia literária do tipógrafo, Broca é categórico ao dizer que suas poesias eram de pouco valor. No entanto, discute que a parte intitulada "O Livrinho das Moças" de sua obra póstuma está adequada a uma das tendências românticas do período, mais voltada para os recitais de salões. Do mesmo modo, "Anônimas", de teor mais lírico, encontrou público entre as jovens de sua época.

Na obra que organizou, Barbosa Lima Sobrinho se propõe a resgatar os primórdios do conto no Brasil ${ }^{89}$. Sua intenção não foi coligir obras-primas do gênero, mas tentar apresentar as primeiras produções e seus autores, que muitas vezes eram conhecidos por outro tipo de contribuição artística. Entre os trabalhos presentes no volume, estão os de Justiniano José da Rocha, Firmino Rodrigues da Silva, Luis Carlos Martins Pena e Francisco de Paula Brito. Do tipógrafo, dois contos foram selecionados: "A Mãe-irmã: História Contemporânea" e "O Enjeitado", ambos originalmente publicados no Jornal do Commercio no ano de 1839. O primeiro trata da história de uma moça, de família tradicional da corte, que engravida ainda solteira e cria o filho como se fosse seu irmão. No início do conto, Paula Brito, dando vazão à idéia de nacionalismo pregada pelo romantismo, descreve uma personagem com características típicas do hemisfério sul:

85. Idem, ib., p. 246.

86. Brito Broca, Românticos, Pré-românticos, Ultra-românticos, p. 64.

87. Idem, ib., p. 66.

88. Brito Broca, op. cit., p. 67 apud José Veríssimo, op. cit., p. 159.

89. Barbosa Lima Sobrinho, Panorama do Conto Brasileiro: Os Precursores do Conto no Brasil, 1960. 
Alzira tinha dezesseis anos; não era uma dessas fisionomias que tanta bulha fazem nos romances que vêm da velha Europa; era cá da América, e era bela quanto podia ser; não tinha essa cor de leite, que tanta gente faz entusiasmar, mas tinha um moreno agradável, próprio dos trópicos $[\ldots]^{90}$.

"O Enjeitado" narra a vida de um homem que, buscando a identidade de seus pais, abandona a mulher que ama. E é esta mesma jovem quem depois lhe revela a verdade: ele foi o fruto de um adultério. Seu pai havia sido assassinado pelo marido da mãe, que antes de morrer encarcerada, sofrera anos de tortura. Após uma longa separação, os protagonistas se encontram, ela está à beira da morte e ele é o religioso que vai ministrar-lhe a extrema unção.

Novamente, buscando tons de brasilidade para seu conto, o autor compara o trabalho dos romancistas brasileiros com o dos europeus, que dispõem de histórias antigas, castelos feudais, condes, salões dourados, palácios, pontes levadiças:

[...] custará a crer que nos apresentamos ao público com tão singelas narrações; mas nós, cuja vida é de ontem, cuja história é toda contemporânea, cujos anais ainda não estão escondidos no pó dos velhos cartapácios enterrados no fundo das bibliotecas, contamos só o que vemos e ouvimos, emprestando-lhe apenas alguns vestidos ${ }^{91}$.

Em A Vida Literária no Brasil durante o Romantismo ${ }^{92}$, de Ubiratan Machado, Paula Brito é primeiramente lembrado em capítulo dedicado à análise do papel das livrarias em seu tempo. Como se sabe, as primeiras gerações românticas iniciaram a tradição das reuniões de escritores em livrarias, que se converteram em uma espécie de clube literário, onde havia espaço para a leitura de poemas, debates teóricos, conversas triviais e até mesmo para a consulta das novidades de Paris. Nesses termos, a loja de Paula Brito é considerada a herdeira da Livraria de Mongie, que funcionou de 1832 a 1853 e teria sido o primeiro ponto de encontro de intelectuais. O tipógrafo, neste texto, é descrito da seguinte forma:

Figura humana excepcional, modesto mas muito firme em suas resoluções e de uma lealdade a toda prova. Francisco de Paula Brito começou a congregar intelectuais ao seu redor em 1849, quando lançou A Marmota na Corte. [...] Homem precavido e conciliador, Brito antecipava-se a possíveis desentendimentos não admitindo discussões, principalmente políticas, em sua loja ${ }^{93}$.

Toda a plêiade de personalidades da literatura, da política, do jornalismo e do meio artístico que freqüentavam o estabelecimento do tipógrafo também é citada neste texto. Inclusive, segundo Ubiratan Machado, foi esse ambiente informal e descontraído que despertou a idéia da criação da sociedade Petalógica.

90. Idem, ib., p. 185.

91. Idem, ib., p. 197.

92. Ubiratan Machado, A Vida Literária no Brasil durante o Romantismo, 2001.

93. Idem, ib., p. 56. 
Falando sobre as dificuldades encontradas pelos primeiros românticos para terem suas obras publicadas - como o fato de que as tipografias costumavam imprimir e comercializar especialmente folhetos políticos e manuais de devoção, cabendo aos próprios autores arcar com os custos de seu volume - Ubiratan Machado comenta que Paula Brito foi um dos primeiros a trabalhar para que esse quadro fosse alterado ${ }^{94}$. Uma vez que ele publicou trabalhos de autores contemporâneos por seu próprio risco, sem qualquer ônus para os autores ${ }^{95}$. Do modo similar, o tipógrafo laçou mão do regime de subscrição para publicar diversas obras nacionais; assim, o autor não tinha qualquer encargo e era mais certo que a tipografia não arcaria com prejuízos. Quando lhe parecia que algum texto poderia cair no gosto dos leitores de seu periódico, Brito convocava os interessados, por meio de anúncios, indicando o local onde deveriam assinar a lista para solicitar um exemplar do livro. Quando o número de subscritores atingia o de exemplares programados para a edição, o manuscrito entrava no prelo.

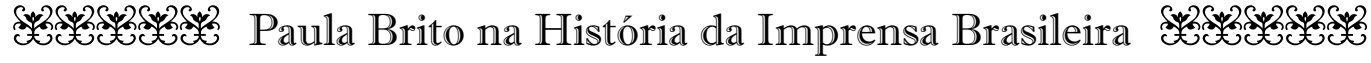

Até o momento, a história da imprensa no Brasil ainda não foi exaustivamente estudada. Diversos pesquisadores dedicaram-se ao tema, outros continuam nessa área de atuação. No entanto, há poucas obras que ofereçam um panorama histórico suficientemente abrangente para o entendimento do desenvolvimento desse aspecto da comunicação no Brasil.

História da Imprensa no Brasil é uma das obras de referência nesse campo de estudo. Nela, Nelson Werneck Sodré comenta sobre Francisco de Paula Brito quando discorre sobre a imprensa no Império. O autor informa que em 1855 Machado de Assis estreou na Marmota, o jornal de Brito que "anunciava romances e novelas anônimas, fabricadas aos montes para distrair o espírito das sinhazinhas e dos estudantes"96. Sobre o proprietário da folha, fala-se que foi "figura singularíssima", pois sendo oriundo de família de poucos recursos financeiros, conseguiu, a custa de seu trabalho, fundar dois periódicos, montar sua própria tipografia e ainda reunir em seu entorno personalidades de relevo de sua época, tanto intelectuais como artistas e políticos. Sodré também informa que Paula Brito fez traduções, produziu peças teatrais, dramas e comédias, além de ter criado o Arquivo Municipal da cidade do Rio de Janeiro ${ }^{97}$.

Em Contribuição à História da Imprensa Brasileira (1812-1869)98, de Hélio Viana, há muito mais trechos citando o nome de Paula Brito e de suas tipografias do que buscando, propriamente, informar sobre sua pessoa. Como o autor desta obra se propôs a estudar o que considerou apenas a pequena imprensa do Primeiro Reinado e da Regência, além de jornalistas e panfletários do período, também não há comentários mais profundos sobre os jornais de Brito. Na obra, foram citadas como

94. Ubiratan Machado, op. cit., p. 68.

95. Idem, ib., p. 70.

96. Nelson Werneck Sodré, História da Imprensa no Brasil, p. 222.

97. Idem, ib., p. 223.

98. Hélio Viana, Contribuição à História da Imprensa Brasileira, 1945. 
impressas nas oficinas do tipógrafo as seguintes folhas: O Trinta de Julho (1833), O Limão de Cheiro (1833), O Mestre José (1833), O Homem de Cor (1833), O Restaurador (1833), A Formiga (1833), A Novidade Extraordinária (1835), A Rolha (1838), O Pregoeiro (1839) e O Sova (1839).

Ao contrário do reportado por Ubiratan Machado99, sobre a loja de Paula Brito ter sido a sucessora das reuniões literárias que anteriormente aconteciam na livraria de Louis Mongie, Laurence Hallewell considerou que ambas chegaram a concorrer neste mérito. Em seu entendimento: "como ponto de encontro literário, todavia, Mongie foi totalmente eclipsado pela importância da Sociedade Petalógica na loja de Francisco de Paula Brito, na praça da Constituição"100.

Hallewell ainda registra a hipótese de que a popularidade da loja do tipógrafo era, em parte, derivada da "personalidade marcantemente amistosa e afável" de seu dono, "da qual quase todos os seus contemporâneos dão testemunho"101. Além disso, o fato de que Brito tinha declarado seu estabelecimento um campo neutro dentro das discussões políticas também concorria para ampliar sua aceitação. $\mathrm{O}$ que certamente não contava a favor da loja era sua localização, fora do perímetro mais elegante e freqüentado da cidade, que naquela época correspondia aos arredores da rua do Ouvidor. O autor também afirma que até Paula Brito, quase todos os impressores e livreiros de maior destaque no Brasil eram imigrantes ou filhos de imigrantes, nenhum deles era proveniente de família brasileira.

O Livro no Brasil descreve brevemente, ainda, a história de vida do tipógrafo e comenta sobre a criação da Empresa Tipográfica Dous de Dezembro:

A própria idéia de fundar uma companhia por ações (por mais desastrosa que tenha sido) revela como Paula Brito era capaz de enxergar longe, pois tal iniciativa só se tornara possível exatamente naquele ano, com a promulgação do novo Código Comercial ${ }^{102}$.

Outra informação interessante nesse texto é a de que, ao contrário de muitos "editores" de sua época, que procuravam concentrar os títulos que publicavam em uma determinada área, Paula Brito procurava produzir para o "leitor comum". Nesse sentido, fala-se igualmente que ele foi um dos primeiros tipógrafos a encorajar a literatura brasileira, pois muito além de publicar autores contemporâneos em regime de subscrição, chegou a arcar sozinho com as despesas de edições literárias.

Destacando novamente pontos já bastante explorados sobre Paula Brito - como as origens humildes, o trabalho como tipógrafo, as reuniões em sua loja -, Gráfica: Arte e Indústria no Brasil também expõe algumas informações mais técnicas sobre seu trabalho. Por exemplo, fala-se que ele adquiriu uma impressora a vapor, cinco vezes mais cara que uma manual, e grande quantidade de tipos

99. Ubiratan Machado, op. cit., p. 56.

100. Laurence Hallewell, O Livro no Brasil, p. 154.

101. Idem, ib., p. 155.

102. Idem, ib., p. 159. 
para atender ao gosto cada vez mais refinado de seus leitores ${ }^{103}$. E que com o uso da estereotipia ${ }^{104}$, com matriz de papelão especial de fácil duplicação, ele conseguiu economizar os gastos com chumbo imobilizado em paquês ${ }^{105}$. Também se afirma nesse texto que "Paula Brito foi o primeiro editor no sentido moderno da palavra, já que passou a assumir o risco das edições"106.

\section{Paula Brito na História da Cultura}

Em 1876, foi publicado o Ano Biográfico Brasileiro, organizado por Joaquim Manuel de Macedo a pedido da Comissão Superior de Exposição Nacional ${ }^{107}$. Trata-se de uma coletânea de breves biografias de pessoas que marcaram a história da cultura brasileira naquele período, arranjadas pela data de morte de cada uma, de modo a completar todos os dias do ano.

No terceiro volume da obra, encontra-se o dia 15 de dezembro, dedicado a Francisco de Paula Brito. Logo no início do texto afirma-se que Brito tinha sido "homem de coração generoso, de inteligência feliz e brilhante, a que só faltou ilustração para resplender, distinto artista laborioso e hábil”"108.

Embora as informações biográficas sejam basicamente as mesmas das demais fontes, o organizador busca salientar a vertente política do tipógrafo. Informa que em 1831, quando Brito já trabalhava como compositor, sobrevieram os acontecimentos que culminaram com a abdicação de Pedro I. Ele menciona a insurreição ocorrida no campo de Santana às vésperas do 7 de abril, quando Evaristo da Veiga - nome de destaque entre os liberais moderados e responsável pela edição da folha Aurora Fluminense - teria solicitado ao jovem Paula Brito que improvisasse versos, destinados às tropas e ao povo, pregando ordem, e teria sido prontamente atendido ${ }^{109}$. Alguns anos mais tarde, no entanto, o tipógrafo aparentemente rompeu com Evaristo e tornou-se opositor ao governo regencial. Tempos depois, esse entusiasmo político de Brito arrefeceu, e de exaltado e andradista, ao que consta, ele passou a conservador.

Particularmente sobre as habilidades de Paula Brito, Macedo comenta o seguinte:

Paula Brito foi metrificador, nunca porém chegou a ser poeta: não tinha nem imaginação, nem instrução suficiente para sê-lo: em seus dramas, em suas cenas cômicas, não subiu além do vulgar; em suas traduções para o teatro, não podia ser feliz. Na literatura pátria só teria obscuro lugar.

$[\ldots]$

103. Margarida Cintra Gordinho (org.), Gráfica: Arte e Indústria no Brasil - 180 Anos de História, p. 36.

104. Processo pelo qual se duplica uma composição tipográfica, transformando-a em fôrma compacta, por meio de moldagem de uma matriz, usualmente o flã, sobre a qual se vaza metal-tipo.

105. Paquê, em tipografia, é conjunto de linhas de composição manual ou mecânica, ainda não paginado, e que se ata com um fio para tirar prova.

106. Margarida Cintra Gordinho (org.), op. cit., p. 36.

107. Joaquim Manuel de Macedo (org.), Ano Biográfico Brasileiro, 1876.

108. Idem, ib., p. 545.

109. Idem, ib., p. 546. 
Francisco de Paula Brito foi um dos homens que mais contribuiu para o desenvolvimento aperfeiçoado da arte tipográfica no Rio de Janeiro. Com sua infatigável atividade e tendo estabelecido relações ou correspondentes em quase todas as províncias do Brasil, por estas espalhava numerosas publicações saídas de suas oficinas, tornando-se desse modo verdadeiro elemento de civilização.

Como editor soube animar a juventude talentosa, e por vezes com prejuízo próprio publicou as primícias de inteligências que ensaiavam os primeiros vôos ${ }^{110}$.

Wilson Martins alude à figura de Paula Brito ao dissertar sobre o período que chama de "o reinado do dramalhão" da cultura brasileira. Segundo ele, uma nova orientação estética que perpassa toda a vida social, do teatro à ficção e da poesia à política. Na literatura, cita os mais reconhecidos integrantes da primeira geração romântica, que se repetem aqui, em favor do juízo crítico, que se transcreve em seguida: Gonçalves de Magalhães, Porto-Alegre, Sales Torres-Homem, Justiniano José da Rocha, Firmino Rodrigues Silva e Francisco de Paula Brito. Todos eles, em suas palavras, seriam: "literariamente, medíocres e menos que medíocres, mas tiveram, coletiva e individualmente, um papel histórico de extraordinária importância: são eles os verdadeiros introdutores do novo gosto no Brasil"111. A relevância da Petalógica também é lembrada nesse texto como um centro de produção e difusão de todo o nascente ideário romântico.

Uma peculiaridade pouco mencionada sobre Paula Brito é o seu envolvimento com a música popular brasileira. Em sua História da Música Popular Brasileira, José Ramos Tinhorão busca trazer à luz uma pequena parcela da contribuição do tipógrafo nessa área. Para ele, o surgimento do romantismo - com seu apelo aos sentimentos individuais - levou os poetas da época a encontrar nas modinhas cheias de amores e suspiros o clima ideal para desenvolver o lirismo que caracterizaria a escola. Esse cenário teria contribuído para o aparecimento da moderna música popular urbana - sob a forma das modinhas em parceria - destinada ao consumo de camadas mais amplas da população ${ }^{112}$. Ao que se sabe, a mais antiga formação de uma parceria para criação de música popular aconteceu entre o introdutor do romantismo no Brasil, Gonçalves de Magalhães, e um músico português naturalizado brasileiro, Rafael Coelho Machado. Tinhorão levanta a hipótese de que a dupla teria se conhecido na loja de Paula Brito ${ }^{113}$. Segundo o autor, entre as figuras do movimento romântico que freqüentavam a loja de Brito, as que mais influenciaram na história da música popular brasileira foram o próprio tipógrafo e Laurindo Rabelo, o poeta Lagartixa.

O mais famoso lundu com versos de Paula Brito, "A Marrequinha de Iaiá", foi produzido em parceria com o músico Francisco Manuel da Silva - autor de outra composição que mais tarde se tornaria o Hino Nacional Brasileiro - e impresso em 1853 na Tipografia Dous de Dezembro. Para Tinhorão, esse lundu já começava por um jogo de palavras, pois em seu título a palavra "marrequinha"

110. Idem, ib., p. 547.

111. Wilson Martins, História da Inteligência Brasileira, p. 247.

112. José Ramos Tinhorão, História Social da Música Popular Brasileira, p. 131.

113. Idem, ib., p. 134. 
poderia ser interpretada tanto como uma parte do vestuário feminino (tecido pregueado aplicado ao vestido que era amarrado em um laço posterior, na altura das nádegas), como também pelo órgão sexual feminino. Cita-se aqui a letra música, que saiu sob o título "Lundu da Marrequinha" no jornal de Paula Brito:

Os olhos namoradores

Da engraçada iaiazinha, Logo me fazem lembrar Sua bela marrequinha.

Iaiá, não teime,

Solte a marreca,

Senão eu morro,

Leva-me a breca.

Se dançado à brasileira,

Quebra o corpo a iaiazinha,

Com ela brinca pulando

Sua bela marrequinha.

Iaiá, não teime, etc.

Quem a vê terna e mimosa, Pequenina e redondinha, Não diz que conserva presa

Sua bela marrequinha.

Iaiá, não teime, etc.

Nas margens da Caqueirada, Não há só bagre e tainha;

Ali foi que ela criou

Sua bela marrequinha.

Iaiá, não teime, etc.

Tanto tempo sem beber...

Tão jururu... coitadinha!...

Quase que morre de sede

Sua bela marrequinha.

Iaiá, não teime,

Solte a marreca,

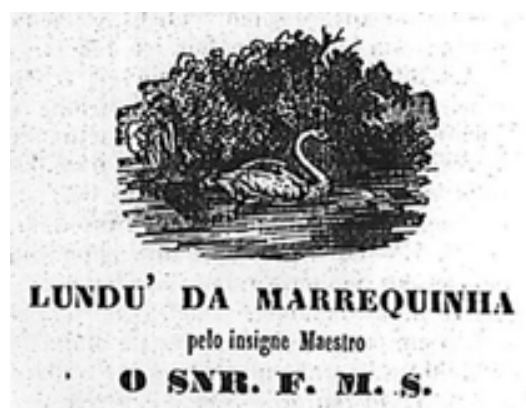

Figura 20. Vinheta que adornava o "Lundu da Marrequinha" na Marmota Fluminense. 
Senão eu morro,

Leva-me a breca ${ }^{114}$.

Paula Brito foi ainda autor da letra dos lundus "Ponto Final", composto em parceria com o músico J. J. Goiano, e "Viva São João", este apenas com a indicação "música de um baiano".

Retomando a questão da afro-descedência do tipógrafo, suscitada por Melo Morais, há relativamente poucos ensaios que o apresentem a partir dessa característica. Talvez um dos primeiros seja o artigo de Gonzaga Duque, publicado em 1941, na revista Dom Casmurro. Neste texto, a memória do tipógrafo é resgatada para fazer parte da construção do perfil de Cruz e Souza:

Depois de Paula Brito, que foi mais versejador do que poeta, não se conhece na literatura pátria outro negro que, como Cruz e Souza, houvesse chegado a um destaque tão evidente.

Convém notar a tempo que a reputação conquistada por Paula Brito resultou mui especialmente do seu instinto de coletivismo; Paula Brito era uma vocação mercantil e possuía como todos os indivíduos dessa espécie a habilidade inata da sociabilidade, e foi reunindo em torno de sua afável e inteligente pessoa todos os homens intelectuais do seu tempo, alguns apenas incipientes nas letras como Casimiro de Abreu e Machado de Assis, que o seu nome cresceu na estima da gente culta.

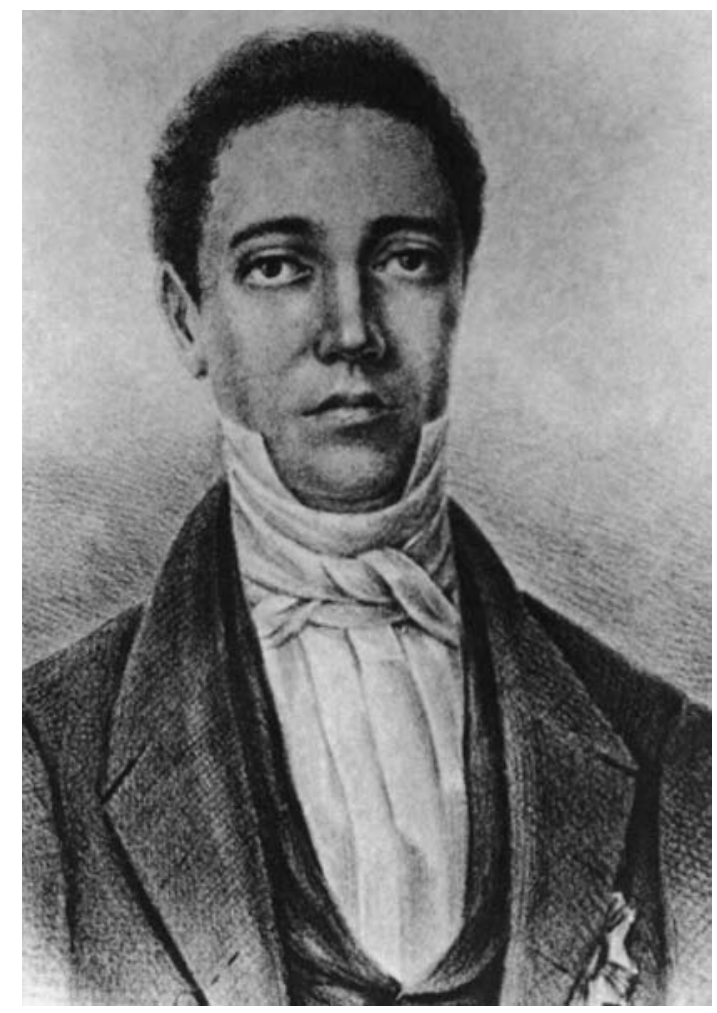

Cruz e Souza era unicamente poeta, e por ser exclusiva, organicamente poeta, faltava-lhe de todo o jeito atraente dos sociáveis, que são excessivamente comunicativos $^{115}$.

Paula Brito também é mencionado no catálogo da exposição "Mostra do Redescobrimento", em um volume totalmente dedicado à arte afrobrasileira. No texto que apresenta uma sucinta biografia do tipógrafo, ele é descrito como "uma das figuras intelectuais mais interessantes do Segundo Reinado" e "primeiro editor brasileiro"116. Há também neste catálogo um retrato pouco divulgado de Brito, uma litografia assinada por Louis Aléxis Boulanger (c. 1840-1845).

Figura 21. Retrato de Francisco de Paula Brito (c. 18401845), litografia de Louis Alexis Boulanger.

114. Marmota Fluminense, n. 390, p. 4, 9 ago. 1853. Após a letra do lundu, há a seguinte informação: "Vende-se a 400 réis, na loja do editor, praça da Constituição, n. 64, unicamente".

115. Gonzaga Duque, “O Poeta Negro”, Dom Casmurro, p. 4, 8 mar. 1941.

116. Fundação Bienal de São Paulo, Mostra do Redescobrimento: Arte Afro-brasileira, p. 219. 


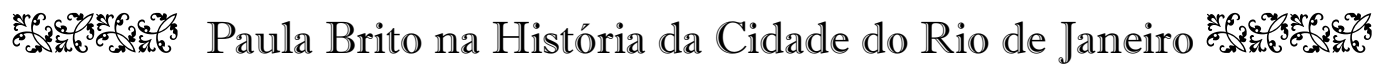

Em sua obra Aparência do Rio de Janeiro, Gastão Cruls se propõe a resgatar a história da cidade descrevendo alguns de seus pontos principais. Em trecho dedicado à "Praça do Rossio", o autor comenta:

Famosos, também, nessa mesma Praça foram a tipografia e a Loja do Canto, de Francisco de Paula Brito, também intitulada Loja do Chá, do melhor que há. Ficava na face em que está o Teatro João Caetano e a tipografia dava fundos para a rua da Lampodosa. Paula Brito, que exerceu as funções de mestre de arte tipográfica do imperador D. Pedro II, foi redator-chefe de vários periódicos, sobretudo A Marmota, e da sua oficina saíram várias obras de escritores nacionais, como A Confederação dos Tamoios, As Primaveras, os romances de Teixeira e Sousa e as comédias de Martins Pena ${ }^{117}$.

Cruls lembra que além de serem impressos em loja de Paula Brito versos dedicados a consagrar artistas de renome na época, como Stolz e Candiani, muitas dessas poesias eram lá mesmo compostas, pelos intelectuais freqüentadores do local.

Em obra de temática semelhante, Vivaldo Coaracy igualmente se recorda da oficina de Paula Brito localizada no Largo do Rossio e das afamadas reuniões de figurões que ali tinham lugar. Para ele, "a livraria de Paula Brito desempenhou papel de relevo na evolução da cultura nacional"118.

Delso Renault, em estudo dedicado a delinear o perfil da cidade do Rio de Janeiro por meio de anúncios em jornais, faz algumas alusões à Paula Brito. Inicialmente, comenta que "as lojas, boticas e tipografias são os centro de reunião, onde se discute a política e se fala de literatura. A tipografia de Paula Brito tem uma ação marcante: concentra o grande movimento literário, que abrange o período romântico de 1840 a 1860"119. Investigando algumas peculiaridades dos anúncios, o autor chega a registrar que Paula Brito, assim como outros donos de tipografia, oferece para o dia de finados "em prosa ou verso, em papel, cartão ou cetim - Inscrições - para catacumbas"120.

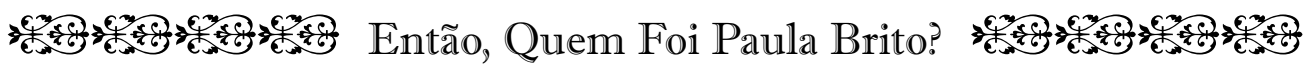

Foi ele o primeiro editor que realmente pôde ostentar esse nome, como afirmou Machado de Assis ${ }^{121}$ ? Foi o tipógrafo-editor que por si se fez escritor e chegou a ser poeta, como registrou

117. Gastão Cruls, Aparência do Rio de Janeiro, vol. 2, p. 369.

118. Vivaldo Coaracy, Memórias da Cidade do Rio de Janeiro, pp. 97-99.

119. Delso Renault, O Rio Antigo nos Anúncios de Jornais (1808-1850), p. 160.

120. Idem, ib., p. 199.

121. Machado de Assis, Diário do Rio de Janeiro, 3 jan. 1865, em Machado de Assis, Crônicas, vol. 2, p. 264. 
Moreira de Azevedo ${ }^{122}$ ? Ou foi o mais legítimo representante e a mais "transcendente irradiação" das artes tipográficas no Brasil, como declarou Melo Morais ${ }^{123}$ ? Talvez, ainda, tenha sido uma mistura de tudo - tipógrafo, livreiro, editor, poeta e jornalista - motivada por ardores patrióticos, como sugeriu Eunice Ribeiro Gondim ${ }^{124}$.

Claro está que Francisco de Paula Brito foi mestre-impressor e que, tendo adquirido sua própria oficina, além de comercializar as obras que ali imprimia, chegou ali a exercer funções de editor, no sentido atual do termo, entendido como aquele que, além de escolher e coordenar a edição de um título, promove minimamente a coesão de um grupo em torno de um princípio cultural. Talvez os papéis que desempenhou como poeta, tradutor e jornalista possam ser considerados efeitos secundários da sua principal dedicação à tipografia.

Pode-se dizer também que Paula Brito foi um empreendedor. Findados os ardores políticos da década de 1820 e os tumultos que tiveram espaço na década de 1830, o Segundo Reinado tornou-se um período de relativa estabilidade. Entrava em cena a idéia de criação de perfil de nação para o Brasil e o nascente romantismo tomava parte na campanha, encarregado da nacionalização literária. Ao mesmo tempo, a nobreza improvisada, que não podia se orgulhar de ser tradicional nem tampouco de sua linhagem, podia apenas gabar-se de sua "cultura"; e nisso foi prontamente seguida pela burguesia urbana. Paula Brito conseguiu enxergar o que se passava na corte, viu que havia espaço para o comércio de textos literários, especialmente de autores brasileiros, divisou a possibilidade de lançar seus próprios periódicos de variedades para a burguesia interessada em cultura e assim o fez. Com isso, como conseqüência, ele acabou oferecendo ferramentas a muitos jovens aspirantes à produção literária, uma vez que, como bem lembrou Brito Broca, não havia "velha geração" no romantismo nascente ${ }^{125}$.

122. Moreira de Azevedo, op. cit., p. XIII.

123. Melo Morais Filho, op. cit., p. 20.

124. Eunice Ribeiro Gondim, op. cit., p. 10.

125. Brito Broca, op. cit., p. 64. 


\section{Capítulo 3}

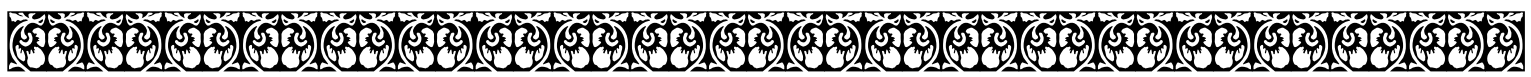 Machado de Assis na Marmota

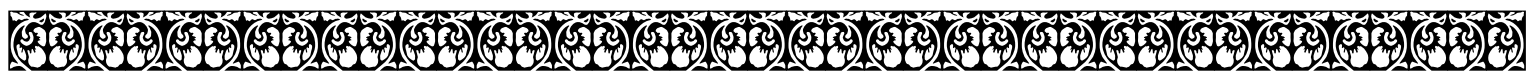

Alguns aspectos do discurso histórico sobre Joaquim Maria Machado de Assis funcionam mais para caracterizar a origem desse discurso do que propriamente o autor e a configuração de sua obra. Um deles em particular auxilia uma possível visão do escritor e consiste no fato de que ele sempre foi muito ajustado a grupos, tendo passado pela vida em meio a companheiros aos quais se unia sobretudo pelo interesse às Letras. O primeiro desses grupos foi A Petalógica, que se criou em torno da Marmota e o último, a Academia Brasileira de Letras, que ele, ao lado de Lúcio de Mendonça, ajudou a fundar em 1897, presidindo-a desde então até sua morte em 1908. Tendo nascido no Rio de Janeiro em 1839, já aos quinze anos publicava versos no Periódico dos Pobres ${ }^{1}$. Outra informação recorrente é sua origem racial e social, que enfatiza o fato de seu pai ter sido pobre, pardo forro e pintor de paredes. Segundo a mesma tradição, a mãe era portuguesa, da Ilha de São Miguel, e morreu quando o menino tinha dez anos. Em 1855, aos dezesseis, aproxima-se da revista de Paula Brito e aí prossegue publicando as composições do período inicial, como os poemas "Ela"2 e "A Palmeira", na fase em que o jornal se chamava Marmota Fluminense. Em 1858, já na fase em que a revista se intitulava A Marmota, o escritor publicou o seu primeiro conto, "Três Tesouros Perdidos"4.

Como se sabe, Machado de Assis foi poeta, cronista, contista, romancista, crítico e autor teatral. Era autodidata, tendo freqüentado apenas o ensino básico. Quase tudo o que escreveu, desde a juventude até a vida madura, passou primeiro pela imprensa: poesias, artigos, contos, crônicas, críticas e romances. Esse fato, se estimulava a produção do autor, pela publicação imediata, trazia também particularidades específicas, que eram dadas pelas características do periódico em que os textos eram veiculados, o que implica a idéia de um possível perfil de leitor. O elemento da vida política e institucional também deve ser levado em conta, pois a presença do poder imperial e a dependência de muitos intelectuais exercem papel importante na formação do artista e do homem.

Como se viu anteriormente, a Marmota foi o primeiro periódico em que o jovem Machado de Assis colaborou continuamente, desde o primeiro texto aí publicado em 1855 até 1861 . Não se pode precisar a data em que Machado de Assis e Paula Brito se conheceram. Para Lúcia Miguel Pereira, “o

1. Trata-se de "À Ilma. Sra. D. P. J. A", soneto identificado por Raimundo Magalhães Jr. em Vida e Obra de Machado de Assis, vol. 1: Aprendizado, pp. 17-21. Atualmente, é conhecido como "Soneto à Petronília", visto ter sido dedicado a uma mulher com esse nome.

2. Marmota Fluminense, n. 539, 12 jan. 1855.

3. Marmota Fluminense, n. 540, 16 jan. 1855.

4. A Marmota, n. 914, 5 jan. 1858. 
conhecimento deve datar de princípios de 1855", quando "começou então a atividade intelectual de Machado de Assis, atividade que se manteve ininterrupta durante 53 anos, até 1908, até sua morte" Gondin da Fonseca, no entanto, imaginou que tal encontro se tenha dado em meados de 1854, quando o jovem Machado começou a circular pelos pontos mais movimentados da capital do império ${ }^{6}$.

Ao que tudo indica, Joaquim Maria logo estabeleceu relações com os demais colaboradores do periódico, assim como com os freqüentadores da livraria de Paula Brito. Nesse sentido, muito se fala sobre a amizade com Casimiro de Abreu, também colaborador da Marmota, e sobre Caetano Filgueiras ${ }^{7}$. Este se tornou o que hoje pode ser considerado uma espécie de ícone célebre da juventude machadiana, especialmente lembrado pelo prefácio às Crisálidas, no qual se recorda dos tempos de mocidade quando cinco amigos - o próprio Filgueiras, Casimiro de Abreu, José Joaquim Cândido de Macedo Júnior, Gonçalves Braga e Machado de Assis - se reuniam na sala de seu escritório, após o expediente habitual, para "palestras literárias".

Jean-Michel Massa afirma que existe uma certa tendência em crer que Caetano Filgueiras, o mais velho do grupo dos cinco companheiros, foi o primeiro "mestre literário" e confidente de Machado, embora, ao seu ver, este papel tenha sido desempenhado por Francisco Gonçalves Braga". Braga, nascido em Portugal, em 1836, foi igualmente colaborador da Marmota, onde publicou diversas poesias que mais tarde foram reunidas em volume, as Tentativas Poéticas, de 1856.

De fato, parece aceitável julgar que Francisco Gonçalves Braga tenha sido um dos modelos para os primeiros trabalhos literários de Machado de Assis. A poesia "Ela", primeiro texto machadiano aparecido na Marmota, tem como epígrafe versos de Braga. Já seu segundo poema divulgado no mesmo periódico, "A Palmeira", é "oferecido, dedicado e consagrado" a Francisco Gonçalves Braga. Seguindo a cronologia de publicação, o quarto poema, "Saudades", além de ser dedicado a Braga e ter como epígrafe versos do poeta português, também descreve a dor causada pela ausência do amigo que estava em Portugal. Logo na primeira estrofe, o poeta tematiza o sentimento de saudade ao companheiro ausente:

\footnotetext{
Recebe, ó Braga, o meu canto,

Que eu cá de longe t’envio;

São orvalhadas do pranto

Secas flores do estio;

É a prova da lealdade

Duma constante amizade ${ }^{10}$.
}

5. Lúcia Miguel Pereira, Machado de Assis: Estudo Crítico e Biográfico, p. 49.

6. Gondin da Fonseca, Machado de Assis e o Hipopótamo, p. 87.

7. Alfredo Pujol, Machado de Assis, pp. 8-9.

8. Machado de Assis, Crisálidas: Poesias, Rio de Janeiro, Livraria de B. L. Garnier, 1864. O autor manifestou vontade de que esse prefácio jamais fosse reimpresso, mas pode ser lido, por exemplo, nas Obras Completas da Jackson.

9. Jean-Michel Massa, A Juventude de Machado de Assis, p. 160.

10. Marmota Fluminense, n. 578, 1 maio 1855. 
Explorando o mesmo tema, uma segunda poesia intitulada "A Saudade"11 traz como epígrafe versos novamente extraídos de Braga:

\author{
Saudade! ó casta virgem, \\ Qu'inspiraste a Bernardim, \\ Nos meus dias de tristeza \\ Consolar tu vens a $\mathrm{mim}^{12}$
}

Ainda em 1855, talvez após o retorno de Braga ao Brasil, saiu nas páginas da Marmota a poesia "No Álbum do Sr. F. G. Braga"13, aberta com versos de Gonçalves de Magalhães. Neste trabalho, Machado compara o amigo a Bernardim Ribeiro, Garrett e Virgílio. Braga respondeu também em versos a esses elogios:

\author{
Ao SENHOR J. M. M. D’Assis \\ (em resposta) \\ Com que expressões eu hei de agradecer-te \\ Meu bom e caro amigo, \\ Os versos sonorosos com que honraste \\ A minha estéril musa? \\ Na mente confundida em vão procuro \\ Uma idéia somente \\ Que diga a emoção que sinto n’alma \\ A ler os versos teus, \\ Construídos de frases lisonjeiras \\ Que confundem meu estro! \\ Mas qu'importa que a mente esteja rude \\ Se tem fogo meu peito, \\ Se sente, e os lábios meus dizer-te podem \\ Seus puros sentimentos \\ Em dous termos somente reunidos: \\ Gratidão, Amizade ${ }^{14}$ ?
}

11. Marmota Fluminense, n. 632, 5 out. 1855. O primeiro trabalho com esse nome foi publicado na mesma revista, n. 564, 20 mar. 1855.

12. Francisco Gonçalves Braga, “A Saudade”, em Tentativas Poéticas, pp. 59-60.

13. Marmota Fluminense, n. 634, 9 out. 1855

14. Francisco Gonçalves Braga, Marmota Fluminense, n. 636, 14 out. 1855. 


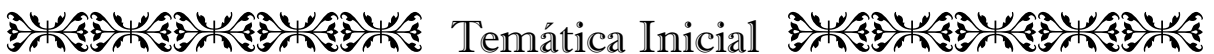

Parece claro que, embora a proximidade com Francisco Gonçalves Braga tenha oferecido estímulo para a produção inicial de Machado de Assis, o poeta português foi apenas uma personagem secundária de um cenário romântico que então se configurava. Endossando um pensamento existente, José Aderaldo Castello concorda que o romantismo brasileiro foi projetado de fora para dentro ${ }^{15}$. A poética e os ideais românticos ocidentais, assim como os reconhecidos estilos de época, vieram ao encontro da herança colonial, e convergiram para a configuração do que, na época, se entendia como "identidade nacional". Juntamente com a elaboração da forma brasileira da língua portuguesa, esses elementos instruíram aquela geração com características próprias para o romantismo no Brasil.

A poesia, como se sabe, foi o produto imediato dos debates crítico-teóricos sobre o romantismo e apresentou, inicialmente, mais destaque que a prosa, desencadeando a reforma na literatura brasileira, até então projetada sobre moldes europeus. Logo após a repercussão da produção de Gonçalves Magalhães, entre o lançamento de Niterói e de Suspiros Poéticos e Saudades até o surgimento de revistas literárias de renome na década de 1840, como a Minerva Brasiliense e Guanabara, começaram a surgir os grandes nomes da poesia romântica no Brasil. Eles ampliaram as propostas iniciais, formais e temáticas, e delinearam a poesia romântica brasileira. Tais poetas tematizaram o lirismo amoroso de feição pessoal, o indianismo épico e lírico, a natureza, o patriotismo, a religiosidade, associados a algumas tópicas sociais e libertárias. A tradição consolidou alguns dos poetas que, em diferentes períodos da mesma época, escreveram conforme o código romântico, entre os quais, além de Magalhães, permanecem ainda lembrados e estudados: Gonçalves Dias, Casimiro de Abreu, Fagundes Varela, Álvares de Azevedo, Junqueira Freire, Castro Alves e Sousândrade ${ }^{16}$.

Gonçalves Dias, como é sabido, abordou praticamente todos os temas românticos: o indianismo, a natureza e sua evocação associada à idéia de Deus, impulsos de solidão e contemplação, saudosismo pátrio e o amor ideal. Muito atento ao ambiente local, Machado de Assis explora esses mesmos assuntos, então bastante freqüentes nos poetas brasileiros. Do mesmo modo, ele não desdenha a experiência da língua portuguesa na Europa, especialmente, a de Almeida Garrett. Anos mais tarde, já maduro e reconhecido, o autor de Dom Casmurro lembra as sugestões literárias de sua mocidade, em crônica sobre o centenário de nascimento do poeta e romancista romântico português:

Estávamos perto do óbito do poeta [Garrett]; tínhamos balbuciado as suas páginas, como as de outros, que também foram poetas ou prosadores, romancistas ou dramaturgos, oradores ou humoristas, quando ele foi tudo isso a um tempo, deixando um primor em cada gênero. Éramos moços todos. [...]

Nem só éramos moços, éramos ainda românticos; cantava em nós a toada de Gonçalves Dias, ouvíamos Alencar domar os mares bravios da sua terra, naquele poema em prosa que nos deixou, e Álvares de Azevedo era o nosso aperitivo de Byron

15. José Aderaldo Castello, A Literatura Brasileira, vol. 1, p. 185.

16. Idem, ib., pp. 221-229. 
e Shakespeare. De Garrett até as anedotas nos encantavam. Cá chegavam por cima dos mares o eco dos seus tempos verdes e maduros, os amores que trouxera, a amizade que eles e a poesia deram e mantiveram entre o poeta luso e o nosso Itamaracá, o pico dos seus ditos e finalmente as graças teimosas de seus últimos anos ${ }^{17}$.

Dessa maneira, Machado rearticula em seus trabalhos elementos captados de seu momento cultural. Tome-se por exemplo a poesia "A Palmeira", dedicada a Braga, que descreve uma planta nativa, uma manifestação da natureza exterior, assunto que sempre esteve no escopo do românticos, haja vista o primeiro verso da "Canção do Exílio", "Minha terra tem palmeiras"18. Em "A Palmeira", além de caracterizar a árvore, o poeta segreda-lhe suas amarguras e pede que ela esconda o seu pranto:

$$
\begin{aligned}
& \text { Como é linda e verdejante } \\
& \text { Esta palmeira gigante } \\
& \text { Que se eleva sobre o monte! } \\
& \text { Como seus galhos frondosos } \\
& \text { S'elevam tão majestosos } \\
& \text { Quase a tocar no horizonte! } \\
& \text { [...] } \\
& \text { Adeus, palmeira! ao cantor } \\
& \text { Guarda o segredo de amor; } \\
& \text { Sim, cala os segredos meus! } \\
& \text { Não reveles o meu canto, } \\
& \text { Esconde em ti o meu pranto } \\
& \text { Adeus, ó palmeira!... adeus }{ }^{19} \text { ! }
\end{aligned}
$$

Como se sabe, a Lua foi igualmente motivo importante na poética romântica. Dentre os trabalhos que desenvolveram o tema, talvez "A Lua de Londres" ${ }^{20}$, de João de Lemos, tenha sido um dos mais difundidos influentes em seu tempo. Gonçalves Dias, do mesmo modo, participou da tendência, no hino "A Lua"21. Joaquim Maria, novamente, não se esquivou desse costume e produziu "A Lua", poema em que, de certo modo, ele descreve o astro, ao mesmo tempo em que sugere que sua imagem no firmamento é capaz de amenizar a melancolia do eu lírico:

\section{Se brilhas no etéreo cume \\ Cessam meus ardentes prantos}

Cessa a dor.

17. Gazeta de Notícias, 4 fev. 1899, em Machado de Assis, Crítica Literária, pp. 253-254.

18. A. Gonçalves Dias, Cantos: Coleção de Poesias, p. 3.

19. Marmota Fluminense, n. 540, 16 jan. 1855.

20. João de Lemos, Cancioneiros, p. 27.

21. A. Gonçalves Dias, op. cit., p. 176. 


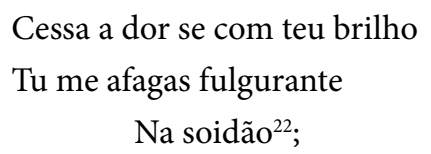

Partilhando ainda do discurso poético dominante, Machado aplicou-se à poesia de cunho descritivo, como se observa em "O Pão d'Açúcar". Nesse texto, a voz poética incorpora um aspecto da paisagem carioca como meio não só de participar do discurso poético do tempo, mas também como forma de dialogar com as tópicas associadas à idéia de brasilidade, que excedia a esfera da poesia $\mathrm{e}$ penetrava o âmbito das discussões em torno das consolidações dos valores do Segundo Reinado. $\mathrm{O}$ poema inicia com os seguintes versos:

Salve, altivo gigante, mais forte

Que do tempo o cruel bafejar,

Que avançado campeias nos mares,

Seus rugidos calado a escutar ${ }^{23}$.

Além do diálogo com os elementos culturais mencionados acima, deve-se destacar que o poema de Machado relaciona-se de modo particular com um texto bem conhecido de Gonçalves Dias, decisivo para a formação do ideário romântico do período. Trata-se do poema "Gigante de Pedra”, publicado um pouco antes, no último grande livro do autor de Primeiros Cantos:

Gigante orgulhoso de fero semblante,

Num leito de pedra lá jaz a dormir!

Em duro granito repousa o gigante

Que os raios somente poderão fundir ${ }^{24}$.

Se um texto evoca o outro, não será demais perceber que ambos evocam o acidente geográfico que marca a paisagem do Rio de Janeiro e que viria a se constituir num símbolo da cidade e de seu ambiente natural. Conforme a sensibilidade da época, tratava-se de exaltar em versos a força da natureza que aos poucos também se impunha como um monumento cultural, visto que, com o auxílio da poesia, cultura e natureza se fundem para dar lugar a um ícone da cidade e do país. Consciente da importância da poesia na criação dos mitos do Segundo Reinado, o jovem poeta demonstra sensibilidade atuante ao participar do processo.

Depois de compor poemas à palmeira, à Lua e ao Pão de Açúcar, Machado fecha, na Marmota, o ciclo de poemas em que tematiza a transformação da natureza em cultura, publicando no mesmo periódico "Dormir no Campo", cujos primeiros versos são:

22. Marmota Fluminense, n. 601, 17 jul. 1855.

23. Idem, n. 651, 23 nov. 1855.

24. A. Gonçalves Dias, Últimos Cantos, p. 1. 


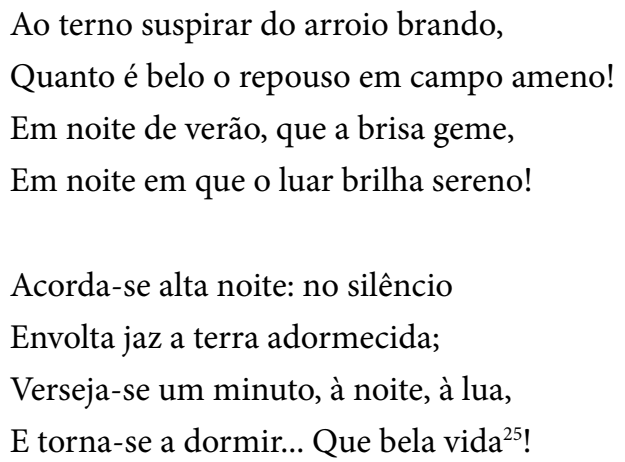

Da literatura de Almeida Garrett, esta peça recupera a ambientação campestre, tão marcada em um dos romances importantes do romantismo português, Viagens na Minha Terra. Como se sabe, esta obra revela, entre outras coisas, o Portugal do interior rural, da vida de trabalho em contato com a natureza, em que, supostamente, a vida flui com mais sinceridade do que no ambiente urbano. Em "Dormir no Campo", observa-se elogio semelhante à natureza amena, o que é, enfim, uma retomada da tópica do locus amoenus da poesia árcade, muito estimada tanto por Garrett quanto por Machado. Mas nesse poema, há renovação do tema bucólico, visto que o eu lírico repousa em campo aberto, sob as estrelas, e acorda com o romper do dia. Ele canta as alegrias de sua vida simples, que não trocaria por outra, "ainda que bela", e vai à procura de sua "rústica donzela".

Ao abordar o romantismo, Afrânio Coutinho aponta como propriedade típica desse estilo o individualismo (subjetivismo, egotismo), uma vez que a atitude romântica é pessoal e íntima. Desse modo, o artista compõe textos que sugerem a idéia de singularidade, insinuando um modo pessoal de ver e compreender o mundo ${ }^{26}$. Anteriormente, José Veríssimo já havia asseverado que "talvez se pudesse dizer que pronunciam o individualismo romântico assuntos e títulos como 'À saudade,' 'A volta do exílio' e outras inspiradas de motivos pessoais [...]"27. Mais uma vez, Machado de Assis não deixou de partilhar das convicções de seu tempo, e consagrou três peças, publicadas em um intervalo de sete meses, ao tema saudade. A primeira, "A Saudade" - dedicado ao seu primo, Henrique José Moreira - joga com dois sentidos da palavra-título, o de lembrança nostálgica e o nome de uma flor (conhecida como saudade ou escabiosa):

\footnotetext{
Mimosa flor do campo, eu te saúdo; Quanto és bela sem seres perfumada! Que te inveja o jasmim, a rosa e o lírio Com todo o seu perfume?
}

Repousa linda flor, num peito f'rido, A quem crava sem dó a dor funesta,

25. Marmota Fluminense, n. 685, 21 fev. 1856.

26. Afrânio Coutinho (org.), A Literatura no Brasil, p. 568.

27. José Veríssimo, História da Literatura Brasileira, p. 149. 
O horrível punhal, que fere e rasga

Um débil coração ${ }^{28}$.

A segunda, "Saudades", como já se mencionou, evoca o sentimento por conta da ausência de Francisco Gonçalves Braga. A terceira, "A Saudade", também anteriormente citada, tem sua epígrafe captada de uma peça homônima do poeta português. Na poesia de Braga, além de "casta virgem" expressão inserida na citação feita por Machado -, a saudade é:

\author{
Meiga Deusa do proscrito \\ Nas horas da solidão, \\ Que lhe afagas com carinhos \\ As penas do coração ${ }^{29}$;
}

O texto de Machado de Assis, de modo similar, incorpora as imagens mitológicas ao seu trabalho, evidenciando uma vez mais que seu romantismo, como o de Garrett, possui ainda estreito laços com a poética setecentista:

Doce virgem do Olimpo rutilante,

Que co’a taça na destra à terra baixas

E o agro, doce líquido entornando

Em coração aflito, meiga esparges ${ }^{30}$

Além da "virgem do Olimpo", nas estrofes seguintes fala-se de "clara Febe" em lugar de Lua. Trata-se do primeiro trabalho machadiano publicado na Marmota a empregar expressões ligadas à mitologia. Nesse sentido, será também o primeiro a demonstrar pretensão de retomar a sintaxe trabalhada da poesia do século anterior, o que pode ser visto como índice de que, além do ambiente imediato de sua cultura, o jovem poeta já demonstrava inclinação pela pesquisa de outros códigos. De fato, a sintaxe desse texto denuncia leituras que vão um pouco além da cultura específica do momento. Havia os modelos de Garrett e Gonçalves Dias, poetas românticos de formação clássica, mas a essa altura, Machado talvez estivesse preocupado em trazer para as páginas da Marmota um traço da poesia histórica do mundo peninsular.

Pode-se identificar também nos trabalhos iniciais de Machado de Assis uma série cuja temática principal é o amor por uma mulher, entendida como personagem lírica. "Júlia", "Lembrança de Amor", "Teu Canto", "Meu Anjo", "Um Sorriso" e "Como Te Amo" foram publicados em um intervalo de três meses e neles o eu lírico idealiza sua amada, que é transposta para um plano mais elevado que o dele próprio.

Há, nesses poemas, determinadas expressões e imagens que de certa forma acabam por se

28. Marmota Fluminense, n. 564, 20 mar. 1855.

29. Francisco Gonçalves Braga, "A Saudade", op. cit.,1856, p. 59.

30. "A Saudade", Marmota Fluminense, n. 632, 5 out. 1855. 
repetir, em "Júlia" pode-se encontrar: "rosa do prado", "purpúreo seio", "aurora formosa", "perfumada brisa", "candura", "anjo" e "meiga virgem”" ${ }^{1}$. Em "Lembrança de Amor", já o primeiro verso retoma o título do trabalho anterior e ressurgem os termos prado e flores:

\author{
Vem, ó Júlia, vem ao prado \\ Vem colher mimosas flores, \\ Para ornar teu níveo seio, \\ Onde vivem os amores. \\ Olha o rubor desta rosa \\ Que simboliza a paixão; \\ Toma-a, põe-na, minha Júlia, \\ Põe-na sobre o coração ${ }^{32}$.
}

O nome da musa a quem se dedica o poema, Júlia, pode não ter consistido em uma escolha aleatória. Segundo Massa, ele pertence a uma tradição literária que remete a Rousseau (Nouvelle Héloise, 1761) e a Byron (Don Juan, 1819) ${ }^{33}$. Igualmente, Garrett, Musset, Emílio Zaluar, Bulhão Pato e outros adotaram esse nome poético. Como se sabe, o mesmo ocorreu nos dois séculos imediatamente anteriores a Machado com os nomes Marília e Anarda. Particularmente na primeira quadra, evidenciam-se ecos das pequenas odes de Tomás Antônio Gonzaga, em que Marília encarna as forças do amor e da elegância feminina.

Em “Teu Canto", Machado, muito preocupado em produzir harmonia poética e em se apropriar da tradição da poesia dialógica (o diálogo campestre), elabora um idílio que retoma a mesma tradição da ode anacreôntica, que ele deve ter aprendido em Gonzaga e em Garrett. Ao comparar a "donzela" com os encantos das flores, o texto imita (repetição, aliteração, eco) também a possível melodia de sua voz, sobretudo na parte final, em que se percebe um adensamento da arte verbal do poeta, em franco processo de maturação:

\author{
Tu és tão sublime \\ Qual rosa entre as flores \\ De odores \\ Suaves; \\ Teu canto é sonoro \\ Que excede ao encanto \\ Do canto \\ Das aves ${ }^{34}$.
}

31. Marmota Fluminense, n. 583, 18 maio 1855.

32. Idem, n. 587, 1 jun. 1855.

33. Jean-Michel Massa, A Juventude de Machado de Assis, p. 136.

34. Marmota Fluminense, n. 600, 15 jul. 1855. 
Este poema é dedicado "a uma italiana" e leva como epígrafe os versos nono e décimo de "Meu Anjo"35. Pagando tributo às conviçcões de seu tempo, que procurava o sentido da poesia na necessária relação do poeta com sua possível biografia, Lúcia Miguel Pereira acredita que a destinatária dessas estrofes seria Anetta Casaloni:

A quem rimaria assim o pobre bardo namorado? Talvez à Casaloni, a primadona italiana em honra de quem versejam todos os poetastros da Marmota, a quem parece dedicada a terceira poesia publicada pelo jovem poeta [sétima, tomando-se a ordem de publicação], com uma expressiva epígrafe do próprio autor ${ }^{36}$.

Preocupado ainda com a relação poesia-biografia, Jean-Michel Massa defende que a musa de Machado de Assis, nesse caso específico, seria Augusta Candiani, outra cantora lírica italiana que foi muito venerada em seu tempo ${ }^{37}$. De qualquer forma, deve-se destacar que a relação mais evidente desse poema seria talvez com a tradição das poesias de amor em que se sugere um possível vínculo imaginário entre vida e texto, ao mesmo tempo que o oculta em favor da dúvida insinuante. Seria igualmente importante também o vínculo com as preferências rítmicas oferecidas pela tradição grega de Anacreonte, que chegam ao português sobretudo por meio de Bocage, Garrett e Gonzaga $^{38}$.

Como se viu acima, "Meu Anjo" é poema de relevo entre os que Machado publicou na Marmota. Empresta os versos "Um anjo desejei ter a meu lado... / E o anjo que sonhei acheio-o em ti!...” do português Carlos Augusto de Sá como epígrafe. Machado novamente constrói um singelo idílio de amor, comparando, dessa vez, a amada com um anjo descido dos céus:

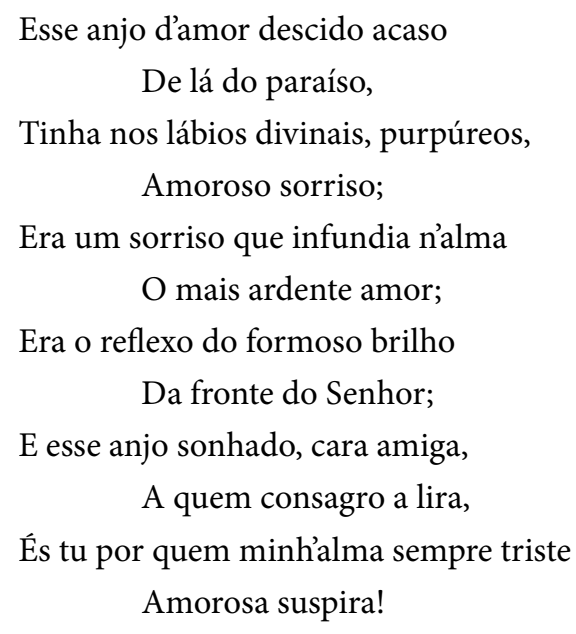

35. Idem, n. 603, 24 jul. 1855.

36. Lúcia Miguel Pereira, op. cit., p. 50.

37. Jean-Michel Massa, A Juventude de Machado de Assis, pp. 126-135.

38. Antonio Candido, em Formação da Literatura Brasileira, ao analisar Marília de Dirceu, explica a força dessa tradição na poesia setecentista de língua portuguesa, à qual ele filia boa parte do livro de Tomás Antônio Gonzaga. 
Em "Um Sorriso" ${ }^{39}$, Machado chama sua amada de "virgem mimosa", "meiga donzela" e "linda rosa". A epígrafe dessa poesia são versos quinto e sexto extraídos de "A Minha Rosa”, de Almeida Garrett:

\author{
Quem, se uma vez pôs os olhos \\ Naquela - face tão bela, \\ Não viu nela - a sua estrela, \\ Rainha dos seus amores? \\ Em seus lábios um sorriso \\ É a luz do paraíso; \\ E o corar da face linda \\ É desabrochar de rosa \\ Que a manhã, com a sua vinda, \\ Debruçou n’hástea mimosa \\ Para inveja das mais flores \\ - Assim fora ela - singela, \\ A minha rosa tão bela, \\ Nem mudasse assim amores \\ Como as outras folha e cores ${ }^{40}$ !
}

Não é difícil perceber que o vocabulário pouco varia. Tanto o poeta português como o jovem brasileiro falam de suas amadas comparando-as a "rosas". Além disso, é possível detectar em seus textos a presença de substantivos como "manhã", "paraíso" e "flores"; e adjetivos como "mimosa", "bela" e "singela". Destacam-se aqui esses vocábulos e imagens para demonstrar a hipótese segundo a qual o aparente romantismo do texto paga antes tributo ao gênero poético do retrato feminino do que a qualquer beleza em particular. Assim, o poeta de ambientação romântica vai alargando o seu horizonte de referência e se filia à conhecida tradição da poesia neoclássica da ode anacreôntica, que deve, como se viu anteriormente, ter vindo a Machado tanto por meio de Garrett quanto de Tomás Antônio Gonzaga.

Da mesma maneira, em "Como Te Amo", Machado emprega comparações com elementos da natureza para tentar realçar a beleza da entidade feminina imaginada por seu texto:
Eu amo-te como a florinha
Quer bem à serena brisa,
Quando meiga se desliza
Sobre campina relvosa;
Eu te amo como a rola
Ama o bosque solitário
Onde vai por seu fadário

39. Marmota Fluminense, n. 609, 10 ago. 1855.

40. João Batista de Almeida Garrett, Flores sem Fruto, pp. 151-152. 
Carpir-se com voz chorosa.

Eu amo-te como o zéfiro

Ama um flórido jardim

Como a Deus um serafim,

Como o sol azul dos Céus;

Eu amo-te como o Vate

Ama rutilante estrela,

Que é imagem da donzela,

Objeto d'amores seus ${ }^{41}$.

Esse texto retoma o tom mais acentuadamente romântico de três dos primeiros textos machadianos publicados na Marmota e comentados acima: "A Palmeira", "Ela" e "Lua". Em que sentido? No sentido de preferir vocábulos e imagens supostamente mais associados ao repertório sentimental do século XIX do ao mundo rococó das odes anacreônticas de Bocage e Gonzaga. Essa idéia pode se confirmar não só pelo ritmo, mas também pelos sintagmas "bosque solitário", "voz chorosa", "azul do céu" e "rutilante estrela". Nesse aspecto, o texto filia-se à tradição melancólica de Casimiro de Abreu, sem deixar de ser também garrettiano. É forte a presença do termo "rola", que conduz o poema para o lamento nostálgico do poeta de As Primaveras. Por outro lado, persistem seqüências típicas do arcadismo neoclássico, como "zéfiro", "campina relvosa" e "flórido jardim". Tomando esse poema como modelo, pode-se dizer que, no conjunto, a natureza da poesia machadiana da Marmota dividese entre o jardim bucólico da poesia neoclássica e a roça melancólica da recente tradição brasileira. Em outros termos, pretende-se dizer que o poeta, cujo estilo se acha apenas em embrião, oscila entre a tradição européia que lhe era possível (aquela da língua portuguesa de Garrett e Bocage) e a sugestão mais à mão do romantismo brasileiro da revista de Paula Brito.

Como se percebe pelas notas bibliográficas, todos os poemas comentados anteriormente são de 1855, quando Machado de Assis contava dezesseis anos. Era ainda um adolescente que buscava um caminho próprio para trilhar com seu canto poético. Seus primeiros trabalhos apresentam marcada sugestão do círculo de amizade mais próximo, como dão testemunho as várias alusões a Francisco Gonçalves Braga e as sugestões de Casimiro de Abreu, sem desprezar também modelos mais distantes no tempo e no espaço, mas igualmente próximos de sua sensibilidade, como seriam Gonçalves Dias e, sobretudo, Almeida Garrett.

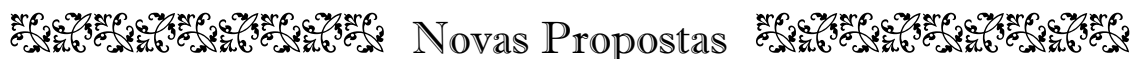

A partir da segunda metade de 1855, Machado de Assis continuava seu exercício poético, mas parecia buscar novas direções, diferentes temas e a experimentação de novas formas. Exemplo dessas 
novas tentativas foi "Paródia". Para Massaud Moisés, paródia "designa toda a composição literária que imita, cômica ou satiricamente, o tema ou/e a forma de outra obra. O intuito é ridicularizar uma tendência ou um estilo que, por qualquer motivo, se torna apreciado ou dominante" 42 . Embora essa definição seja útil, talvez fosse conveniente adicionar que nem toda paródia procura ridicularizar sua matriz, podendo esta servir de motivo inicial para variações da mesma estrutura ou do mesmo tema. Os trechos da peça seguinte de Machado exemplificam, em parte, esse segundo aspecto do conceito de paródia:

\author{
Se eu fora poeta de um estro abrasado \\ Quisera teu lindo semblante cantar; \\ Gemer eu quisera bem junto a teu lado, \\ Se eu fora uma onda serena do mar; \\ Se eu fora uma rosa de prado relvoso, \\ Quisera essa coma, meu anjo, adornar; \\ Se eu fora um anjinho de rosto formoso \\ Contigo quisera no espaço voar; \\ $[\ldots]$ \\ Mas eu não sou astro, poeta, ou anjinho. \\ Nem eco, favônio, nem onda do mar; \\ Nem rosa do prado, ou ave ligeira; \\ Sou triste que a vida consiste em te $\operatorname{amar}^{43}$.
}

Tratando-se de imitação irônica da linguagem típica do romantismo, esse tipo de poesia parece estar inserido em uma tradição bastante difundida no século XIX. Talvez o modelo mais próximo para tal procedimento seja, no Brasil, a segunda parte de Lira dos Vintes Anos, de Álvares de Azevedo, em que se nota o jogo humorístico com os esquemas mais consagrados da linguagem que ele próprio adota na primeira parte do volume. O volume Lísia Poética ou Coleção de Poesias Modernas de Autores Portugueses $^{44}$, por exemplo, apresenta diversos trabalhos de teor semelhante:
No Bom Jesus
Se eu fora das noites o astro formoso, em teu lindo colo quisera brilhar
Teus negros cabelos soltara nos ares,
Se eu fora nas praias a brisa do mar.

42. Massaud Moisés, Dicionário de Termos Literários, p. 340.

43. Marmota Fluminense, n. 611, 14 ago. 1855.

44. José Ferreira Monteiro (org.), Lísia Poética ou Coleção de Poesias Modernas de Autores Portugueses, pp. 167-173. 
Se eu fora dos montes o eco sentido,

Tua fala inspirada quisera imitar;

Se eu fora dos ares a ave mais linda,

No braço da neve te iria pousar.

$[\ldots]$

Mas eu não sou astro, nem lira, nem eco,

Nem ave, nem trova, nem brisa do mar,

Sou homem, que sinto, que sofro, que gemo,

Que o ver-te na terra me pode matar.

[Anônimo]

\section{Ao Autor dos Versos Antecedentes}

Se eu fora das belas o ente mais caro,

Em teu peito amável quisera habitar;

Teus versos tão meigos ouvira com gosto,

Se eu fora mulher capaz de te amar.

Se eu fora d'Enéas igual no cantor,

As trovas, que fazes, quisera imitar,

Se eu fora uma c'roa tecida nos céus

$\mathrm{Na}$ fronte divina t'iria pousar.

$[\ldots]$

Mas eu não sou c'roa, nem bela, nem Stael,

Nem rica soberana capaz de te amar:

Sou fraca mulher, que, virgem d'amores,

Amando os teus versos começo a pensar.

\section{Paródia}

Se eu fora de amor a imagem perfeita,

Teu colo tão meigo quisera habitar;

Se eu fora o mais lindo d'esbeltos mancebos,

Ufano quisera a teus pés me curvar.

Se eu fora a mais terna, fagueira avezinha, 


\begin{abstract}
Teus lábios divinos quisera beijar; Se eu fora o bafejo da brisa amorosa, Suave, em teu peito m'iria infiltrar.<smiles>[AlH2]</smiles>

Mas eu não sou Nume, nem ave, nem flor, Perfume, nem brisa, nem rei do cantar; sou jovem que amo, que gemo e suspiro, Sem ter quem a vida me venha adoçar!
\end{abstract}

\title{
Joaquim Augusto da Cunha Porto
}

Ao se propor a desenvolver uma forma razoavelmente conhecida de poesia, pode-se imaginar que Machado de Assis se sentia mais seguro em sua técnica. Trata-se de um tipo de peça em que prevalece o trabalho com as palavras, rico em metáforas, sem tantas preocupações líricas. Ao contrário do gênero lírico, essa espécie de texto manifesta-se por meio do humor e do virtuosismo técnico, pois pressupões o controle de formas e fórmulas dominante em determinado período. Enfim, essa será a maneira pela qual o futuro grande romancista será conhecido e consagrado, tal como deixam ver as páginas de ironia contra a tradição de Memórias Póstumas de Brás Cubas, Papéis Avulsos e Quincas Borba - livro em que o princípio da paródia exerce papel importante.

"O Gênio Adormecido"45 é dedicado a Antônio Gonçalves Teixeira e Sousa, figura presente na roda literária instalada na loja de Paula Brito e amigo muito próximo do tipógrafo. A terceira estrofe do poema começa com "E tu dormes, Poeta?!" e logo se acrescenta: “Após nela [na lira] entoar linda epopéia, / Que mau condão funesto à nossa pátria / Faz soporoso o Vate!”. Ainda que a intenção primeira da peça seja prestar homenagem a Teixeira e Sousa, chamado de "gênio americano", a "epopéia" a que se faz referência era o poema de sua autoria $A$ Independência do Brasil ${ }^{46}$, que permanecia inacabado desde a publicação dos primeiros cantos, em $1847^{47}$. Desse modo, talvez, a composição machadiana tivesse a intenção de levantar as atenções dos leitores da Marmota para o final do poema épico que seria lançado em breve. O jovem poeta também compara seu homenageado a Alphonse de Lamartine, “[...] o Bardo excelso, / Da França o belo Gênio!", sendo esta a primeira citação do autor francês que influenciou o romantismo tanto em seu próprio país como no restante do mundo ${ }^{48}$.

Dando a entender que seu repertório poético se expandiu, logo após a publicação da poesia em que cita Lamartine, vai a público, na Marmota, "O Profeta"4, cuja epígrafe são versos de Manuel

45. Marmota Fluminense, n. 642, 28 out. 1855.

46. A Independência do Brasil: Poema Épico em Doze Cantos Dedicado, Oferecido e Consagrado a sua Majestade Imperial o Senhor D. Pedro II e Oferecido às Augustas Viúva e Filhas do Herói do Poema foi publicado em dois tomos pela Tipografia Dous de Dezembro de Paula Brito, em 1847 e 1855.

47. Eunice Ribeiro Gondim, Vida e Obra de Paula Brito, p. 111.

48. Massaud Moisés, A Literatura Portuguesa, p. 15.

49. Marmota Fluminense, n. 644, 2 nov. 1855. 
Antônio Álvares de Azevedo: “. ungido crente, / Alma de fogo, na mundana argila"50. Tal como o poema do qual emprestou a epígrafe, Machado insere um subtítulo em seu trabalho: "Fragmento". No entanto, enquanto Álvares de Azevedo de certo modo retrata seu ambiente, o jovem Machado dirige-se ao universo e fala como intermediário de Deus.

Em "Cognac!"51, a influência azevediana é mais presente. Inclusive, Pires de Almeida descreve uma das cenas compostas pelos estudantes paulistanos em um cemitério da cidade, em que os jovens, celebrando o macabro e bebendo na fonte de Byron, recitam diversas poesias, entre elas o "Cognac!" de Machado de Assis:

À distância do cenáculo byroniano, entretanto, o então jovem e inspirado poeta, Machado de Assis leva ao grande templo, em que eram oficiantes Álvares de Azevedo, Bernardo Guimarães e Aureliano Lessa, o tributo de suas adesões, o fogo do seu estro, para aviventar as flamas do ponche com um fervoroso hino ao Conhaque. Por esta poesia, tão espontânea e tão significativa bem se vê que o cantor das Falenas é um desertor de escola, um trânsfuga de bandeira ${ }^{52}$.

Em virtude de sua constância e trabalho ativo, Machado de Assis certamente conquistou seu espaço entre os colaboradores da Marmota. Em dezembro de 1855, como era tradição da folha, foram publicados textos em homenagem ao aniversário de D. Pedro II. O segundo deles, como de costume, era de autoria do editor Francisco de Paula Brito. O primeiro, um soneto, que estampava a página inicial do periódico era assinado por Joaquim Maria Machado de Assis ${ }^{53}$. O relevo tipográfico do soneto e sua posição na folha podem ser interpretados como conquista de um certo prestígio literário, o que, levando em conta a idade do poeta e o número de colaboradores da revista, não era pouco nem sem relevo.

Ratificando a idéia de que suas leituras se tornavam cada vez mais diversificadas, em "A Uma Menina” Machado cita versos do poeta espanhol Manuel José Quintana, datados de 1795:

\footnotetext{
Crece; que el lírio y la purpúrea rosa

tiñan tus gratos miembros a la porfía;

el sol de mediodía

la lumbre encienda de tus ojos bellos;

que el tímido pudor la temple em ellos;

la esencia de las flores

tu dulce aliento sea ${ }^{54}$
}

50. Álvares de Azevedo, "Idéias Íntimas", Obras de Manuel Antônio Álvares de Azevedo, p. 232.

51. Marmota Fluminense, n. 707, 12 abr. 1856.

52. Pires de Almeida, A Escola Byroniana no Brasil, p. 213.

53. Marmota Fluminense, n. 654, 2 dez. 1855.

54. A epígrafe de Machado são os dois últimos versos, trata-se de trecho de "A La Hermosura", em Albert Derozier (ed.), Manuel José Quintana: Poesías Completas, p. 137. 
Nessa poesia, Machado compõe um elogio à inocência de uma moça bonita:

\author{
Nas gotas da pureza inda se anima \\ A tu'alma infantil; \\ Não te nutre inda o peito da malícia \\ Mortífero réptil ${ }^{55}$.
}

Como se vê, o tema da inocência associa-se à infância, visto que o advérbio "ainda" faz pressupor clara insinuação pessimista, muito em moda na poesia byroniana do período. Com o propósito de estabelecer relações entre a prática machadiana e a do grupo de poetas da Marmota, talvez fosse relevante observar que Augusto Emílio Zaluar desenvolveu temática semelhante em "Iaiá":
Eu juro pelos teus olhos,
E a minha jura não mente!
Nunca vi anjo tão belo,
Como tu, lírio inocente!
Dez anos terás apenas...
São dez rosas num rosal;
Todas dez abotoadas,
Num mistério virginal ${ }^{56 !}$

"Um Anjo" 57 ostenta como dedicatória: "À memória de minha irmã". Nesse poema, Machado ficcionaliza o tema da lembrança da morte da irmã, aplicando a tópica geral ao seu caso pessoal, visto que ele perdeu sua irmã caçula aos quatro anos de idade, em 1845. Escreve: "Rasgaste o manto da vida, / E anjo subiste ao céu". A epígrafe dessa peça é de autoria de Zaluar, que registra em "À Morte do Príncipe Imperial D. Pedro Afonso" o falecimento de outra criança e assim expressa seu consolo: "Se da vida deixa o porto, / Tem outra vida nos Céus!" ${ }^{58}$. Machado, no entanto, tomou certa liberdade com os versos e utilizou o tempo verbal passado ao mesmo tempo em que inverteu alguns termos da primeira sentença.

Meses após a publicação do poema dedicado à irmã, o autor divulgou "Minha Mãe"59 - sobre as lembranças de sua infância da falecida figura materna - cujo subtítulo é "Imitação de Cowper". Massa buscou estabelecer uma relação entre o trabalho do poeta inglês, "On the Receipt of My Mother's Picture Out of Norfolk" ${ }^{\prime 60}$, e a poesia do jovem brasileiro ${ }^{61}$. O crítico francês considerou improvável

55. Marmota Fluminense, n. 639, 21 out. 1855.

56. Augusto Emílio Zaluar, Dores e Flores, p. 27.

57. Marmota Fluminense, n. 702, 1 abr. 1856.

58. Augusto Emílio Zaluar, op. cit., p. 84.

59. Marmota Fluminense, n. 767, 2 set. 1856.

60. William Cowper, Poems by William Cowper, vol. 1, pp. 317-322.

61. Jean-Michel Massa, A Juventude de Machado de Assis, pp. 145-147. 
que Machado, em 1856, tenha lido a composição no original em inglês, ao mesmo tempo em que tampouco encontrou indícios de uma versão do trabalho para a língua portuguesa na época. Para ele, a resposta ao impasse encontra-se nos estudos do crítico literário francês Charles Augustin SainteBeuve que divulgou vários trabalhos sobre Cowper e sua escola, inclusive no jornal Le Moniteur, do qual a Marmota, ao que parece, fez algumas transcrições. Semelhante tentativa de transformar um possível afeto pessoal em tópica geral dá a medida do esforço do poeta, que, é possível supor, já vinha se exercitando no conhecimento objetivo das formas poéticas em busca de um conceito de poesia como exercício de imaginação e linguagem.

Em "Minha Musa" ${ }^{62}$, Machado reflete sobre o sentido da poesia e quais seus pressupostos de criação. Trata-se de uma poética bem caracterizada, conforme a tradição dos poemas metalingüísticos. Embora ele se mostre consciente do lirismo sempre presente em suas composições, parece inclinado a ampliar sua temática. Trata-se de uma declaração de princípios poéticos. Se a poesia podia desenvolver os temas da alegria e da tristeza, normalmente identificados como expressão de verdades emotivas, também podia incorporar motivos mais conceituais, como seriam a religiosidade e o patriotismo. Braga abriu suas Tentativas Poéticas com meditação semelhante em "A Cruz e a Lira”, em que canta a incumbência do poeta no mundo, dizendo em seu último verso: "Cumpre assim a missão: - PADECE E CANTA. - "63.

Na Semana Santa de 1856 foi publicado “Consumatum est!" tipográfica ou falha do autor, fato é que a expressão latina foi grafada incorretamente ${ }^{65}$. O título da poesia remete a um trecho da tradução latina da Biblia Sacra Vulgata, "(Tudo) está consumado", as últimas palavras de Jesus Cristo na cruz. João de Lemos também compôs um "Consummatum est"66, do qual Machado de Assis extraiu sua epígrafe, que igualmente aborda os momentos derradeiros da vida de Cristo. Versos diferentes da mesma peça de Lemos serviram de mote para Gonçalves Braga, que compôs o seu "Mortus est Jesus!" em celebração à mesma Semana Santa de 1856 e dedicado ao padre-mestre Francisco de Monte Alverne.

Dois anos depois de publicar “Consumatum est!", Machado volta a usar essa mesma citação bíblica, agora abrindo os versos de "A Morte no Calvário"68, dedicado "ao meu amigo o padre Silveira Sarmento". Esta peça trata do mesmo assunto que a anterior, a crucificação de Jesus Cristo. Entretanto, o apelo religioso nesta parece mais humano e menos grandiloqüente que o da precedente. Sobre sua relação com o padre Silveira Sarmento, posteriormente, o autor comentou o seguinte:

A dedicatória desta poesia ao padre-mestre Silveira Sarmento é um justo tributo pago ao talento, e à amizade que sempre me votou este digno sacerdote.

62. Marmota Fluminense, n. 690, 4 mar. 1856.

63. Francisco Gonçalves Braga, op. cit., p. 14.

64. Marmota Fluminense, n. 698, 22 mar. 1856.

65. Segundo Paulo Rónai, em Não Perca o Seu Latim, p. 44, o correto é Consummatum est (a letra “m” deve ser dobrada).

66. João de Lemos, op. cit., pp. 191-204.

67. Francisco Gonçalves Braga, op. cit., pp.205-212.

68. A Marmota, n. 939, 2 abr. 1858 
Pareceu-me que não podia fazer nada mais próprio do que falar-lhe de Monte Alverne, que ele admirava, como eu.

Não há nesta poesia só um tributo de amizade e de admiração: há igualmente a lembrança de um ano de minha vida. O padre-mestre, alguns anos mais velho do que eu, fazia-se nesse tempo um modesto preceptor e um agradável companheiro.

Circunstâncias da vida nos separaram até hoje $\mathrm{e}^{69}$.

Revendo as matérias que remetem a Álvares de Azedo, Machado de Assis, que havia anteriormente composto "Cognac!" (derivação pessoal de parte de "Idéias Íntimas", de Lira dos Vinte Anos), volta a visitar a temática do poeta paulista e publica "O Sofá", cujas duas primeiras estrofes são:

\author{
Oh! Como é suave os olhos \\ Sentir de gozo cerrar, \\ Sobre um sofá reclinado \\ Lindos sonhos a sonhar, \\ Sentindo de uns lábios d’anjo \\ Um medroso murmurar! \\ Um sofá! Mais belo símbolo \\ Da preguiça outro não há... \\ $\mathrm{Ai}$, que belas entrevistas \\ Não se dão sobre um sofá, \\ E que de beijos ardentes \\ Muita boca aí não dá! ${ }^{70}$
}

Como se vê, também aqui, o poeta da Marmota dialoga com o poeta byroniano, remetendo ao fragmento 9 de "Idéias Íntimas". No número seguinte ao da publicação de "O Sofá", Machado mais uma vez resgata a figura do autor de Lira dos Vinte Anos e divulga "Álvares d'Azevedo", dedicado a Manuel Antônio de Almeida. A peça, que cita inicialmente Porto-Alegre: "Vejo em fúnebre cipreste / Transformada a ovante palma!", sugere que Azevedo, ao morrer, não deixou de existir, pois se tornou imortal graças ao legado de sua obra:

\footnotetext{
Voltaste à terra só! - Não morrem Byrons,

Nem finda o homem na friez da campa!

Homem, tua alma aos pés de Deus fulgura,

Teu nome, poeta, no porvir se estampa ${ }^{71}$ !
}

69. Trata-se de uma nota ao poema "Monte Alverne" coligido na edição de 1864 de Crisálidas. O trabalho foi originalmente divulgado no Jornal do Commercio, em 6 de janeiro de 1858, poucos dias após a morte do frei franciscano. Ver: Lúcia Miguel Pereira, op. cit., p. 54; e Jean-Michel Massa, A Juventude de Machado de Assis, p. 184.

70. “O Sofá”, A Marmota, n. 915, 8 jan. 1858.

71. A Marmota, n. 916, 12 jan. 1858. 
Essa estrofe possui particular interesse, visto que a homenagem se dá por meio da imitação artística do estilo do homenageado, processo que indica já bem formada a habilidade de Machado em incorporar estilos da tradição, manipulando-os em criações originais. Isso será, como se sabe, um dos motivos de valor como artista na maturidade. Mesmo buscando novos caminhos para sua poesia, Machado de Assis não abandou o lirismo. Prosseguiu investigando, nas páginas da Marmota, temas como a tristeza apaixonada, amor, timidez e embaraço diante da amada. Em "Não?", o poeta compõe um hino à beleza de uma figura feminina, falando de seu rosto, de seu talhe, de seu olhar e diz que espera ela apenas uma resposta positiva:

\author{
Um sim! E ao som do teu falar suave \\ Da minha voz extinguirei o som \\ Onde gorjeia uma garganta de ave; \\ Que vale ao homem da palavra o dom? \\ Íntima frase que só nasce d'alma \\ Terei nos olhos pra dizer-t'o então \\ E em troca dela pra colher a palma \\ Do teu amor, anjo terrestre... não ${ }^{72}$ ?
}

Poemas desse tipo talvez ganhem mais interesse, se se aplicar a eles o conceito de poesia como operação imaginosa da linguagem. Assim os lamentos, em vez de expressão de sentimentos, podem ser entendidos como resultado da imaginação construtiva, algo próxima da poesia dramática, em que o eu lírico deve ser entendido como aquele que sente.

"Resignação" ${ }^{73} \mathrm{e}$ "Vai-te" ${ }^{74}$ fazem alusões à situações paralelas. Na primeira, o poeta conformase com o tema do amor não correspondido, pede desculpas à musa por sua ilusão e despede-se. Na segunda, ao que tudo indica, ocorre o tema do retorna da amada, após ter abandonado o eu lírico e partido. Parece tratar-se, igualmente, do tema do amor não correspondido; mas é o eu lírico que implora para que a mulher o deixe, visto que seu coração se encontra "morto". Ambas as composições apresentam similaridades com o "Adeus" de Garrett ${ }^{75}$, em que o emissor pede à sua amada que parta, pois ele não se julga digno de tal sentimento.

Em "Amanhã", o cantor pede ao seu objeto de afeição que não o esqueça após sua morte e em suas últimas estrofes, ele suplica:

\footnotetext{
Um olhar, um olhar desses teus olhos!

Eu o peço, mulher! sobre o meu túmulo

Um olhar de afeição!

Assim o sol - o ardente rei do espaço
}

72. Idem, n. 882,15 set. 1857 .

73. Idem, n. 887,2 out. 1857.

74. Idem, n. 920, 26 jan. 1858.

75. João Batista de Almeida Garrett, Folhas Caídas, pp. 17-22. 
Deixa um raio cair nas folhas secas

Que matizam o chão!

Um olhar, uma lágrima, uma prece,

É quanto basta em única lembrança.

Teresa, ao teu cantor.

Chora, reza, e contempla-me o sepulcro

E na outra vida de um viver mais puro

Terás o mesmo amor ${ }^{76}$.

Experimentando situação poética contrária a esta, no poema "A..." ${ }^{\text {”7 }}$ o eu lírico deseja ardentemente estar próximo de sua amada, quer sentir seu hálito, quer dar-lhe um beijo e entregar-lhe todo o amor. A composição tem como epígrafe versos de Victor Hugo, a primeira citação machadiana do autor francês, "Viens, je suis dans la nuit, mais je puis voir le jour!"78. Tais variações do mesmo motivo contribuem para o estudo da experiência do autor com os temas e formas da tradição, que, aos poucos, vai se transformando e mudando de volume e tonalidades. A inclusão de Victor Hugo em seu horizonte deve ser notada como índice importante na formação de seu referencial técnico e temático.

"Deus em Ti" ${ }^{2}$, no entanto, evoca a presença de Deus em sua amada, não há um amor que necessite de proximidade. Basta apenas observá-la e ouvir a voz dela, para que o eu lírico experimente sensações que, de tão intensas, o aproximam de Deus. Trata-se, como se vê, do tema platônicopetrarquista associado ao conceito de que o amor é projeção da grandeza de Deus ou da idéia do Bem.

A poesia "Esta Noite" apresenta estrutura bem distinta das demais. Trata-se apenas de seis versos em uma única estrofe:

Os teus beijos ardentes,

Teus afagos mais veementes,

Guarda, guarda-os, anjo meu;

Esta noite entre mil flores,

Um sonho todo de amores

Nos dará de amor um céu ${ }^{80}$ !

Apropriando da tradição clássica do poema volitivo, este consiste na expressão do desejo do eu lírico. Por se tratar de um desejo sensual, que aspira à posse da amada, é possível entender o texto como experiência nova nas poesias machadianas da época da Marmota. "Reflexo" 81 também

76. A Marmota, n. 893, 23 out. 1857.

77. Idem, n. 910, 22 dez. 1857.

78. Victor Hugo, Odes et Ballades, “A Toi", p. 169.

79. A Marmota, n. 911, 25 dez. 1857.

80. A Marmota, n. 926, 16 fev. 1858.

81. Idem, n. 936, 23 mar. 1858. 
apresenta uma estrutura enxuta, duas estrofes de seis versos, nas quais o emissor diz que assim como as madonas do céu se refletem nas águas em noites claras de verão, a imagem de sua amada se reflete bem fundo em seu coração.

Sobre os trabalhos inicias de Machado de Assis publicados na Marmota, paira incerteza com relação àqueles cuja atribuição se baseia nas assinaturas "M. A." e "M. de A.", por conta da presença de outro colaborador da folha que poderia usá-las como acrônimo de seus sobrenomes, Moreira de Azevedo. Com respeito às poesias do período, apenas "Ao Carnaval de 1860" se enquadra nessa dificuldade. No entanto, há uma nota da redação do periódico, no número em que foi divulgada a peça, informando aos leitores que Machado de Assis participava daquela edição. Nessa poesia, o eu lírico saúda a festa popular:

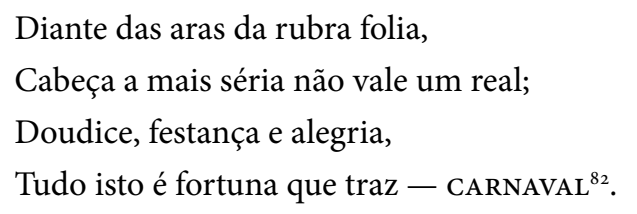

Independentemente das motivações possivelmente empíricas para essa saudação, não se pode esquecer da tradição de versos bacanais, nos quais a tradição clássica saudava as grandes festas, sobretudo aquelas em homenagem a Baco. Mais especificamente, havia também a tradição da poesia satânico-byroniana de São Paulo. Assim, é possível interpretar essa estrofe de maneira mais objetiva, vendo nela não só a festa carioca, mas também o uso da tradição da poesia.

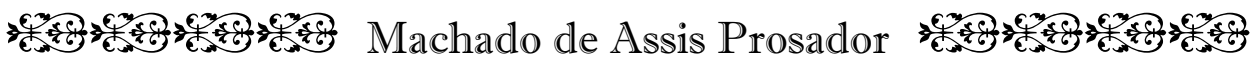

Como quase todos os autores iniciantes de seu período, Joaquim Maria dedicou-se inicialmente à poesia. Desde sua estréia na imprensa, ele havia publicado apenas poemas até junho de 1856 . Até essa data, com exceção de "A Madame Arsène charton Demeur" ${ }^{83}$ e soneto "À Petronília", todas suas composições foram divulgadas na Marmota. Foi então que ele começou uma série de três textos com o título "Idéias Vagas" - em que compôs suas observações sobre diferentes gêneros literários - e que representam sua estréia na prosa.

O primeiro desses trabalhos foi "Idéias Vagas - A Poesia", aberto com uma citação de Lamartine, extraída de suas Méditations Poétiques ${ }^{84}$. Como o poeta francês, Machado buscou definir a poesia como um sentimento inspirado pela natureza que fala à alma. Para ele, tratava-se, da mesma maneira, de um êxtase da alma e dos sentidos em harmonia com o mundo criado por Deus, ou seja, era linguagem do coração, e não da razão. Esse tipo de conclusão, podendo ser interpretado como

82. A Marmota, n. 1.136, 21 fev. 1860.

83. Diário do Rio de Janeiro, 7 fev. 1856, apud Jean-Michel Massa, A Juventude de Machado de Assis, p. 642.

84. Alphonse Marie de Lamartine, "Des Destinées de la Poésie”, Oeuvres Completes, pp. 45-91. 
criação da fantasia, costuma conduzir ao entendimento da poesia romântica como expressão sincera da alma, perspectiva que se tem evitado no presente trabalho. Depois dessas primeiras considerações, o autor procurou traçar uma breve história da poesia, a partir da Grécia. Finalmente, conclui seu artigo com as seguintes palavras:

Aqui terminam as minhas idéias sobre a poesia, e sobre os poetas. Perdoai, leitores, a minha fraca linguagem; é de um jovem que estréia nas letras, e que pede proteção e benevolência. Ainda existem alguns Mecenas piedosos: animai o escritor.

Continuarei as minhas - idéias vagas ${ }^{85}$.

Talvez o "mecenas piedoso" a quem ele se referia fosse, de fato, Francisco de Paula Brito, que além de oferecer-lhe as páginas de sua folha para seu aprendizado literário, era também quem o introduzira ao grupo de intelectuais que freqüentava sua oficina.

Em "Idéias Vagas - A Comédia Moderna”, Machado de Assis abre suas meditações com a seguinte frase: "O teatro, assim como a imprensa, é uma página brilhante pela qual se conhece o estudo e o grau de civilização de um povo"86. Nessa peça, o autor reage contra a farsa vulgar, pois para ele o teatro é uma ferramenta para distração e ensino, a única forma verdadeira de civilizar a sociedade. Mais uma vez, ele cita o tipógrafo Paula Brito no final de seu texto:

Vou acabar. - Cumpre mesmo não tomar muito espaço em uma folha onde se publica um poema de Lord Byron (entre parênteses; dou os emboras ao Sr. Paula Brito por uma publicação tão útil quão agradável).

Nunca escrevi tão vagamente as minhas idéias como hoje: é porque estou com bastante pressa ${ }^{87}$.

O último artigo da série é "Idéias Vagas - Os Contemporâneos: Mont’Alverne" ${ }^{88}$, que evoca a figura do frei franciscano Francisco de Monte Alverne, célebre orador daquele período, como registra Sacramento Blake:

Na tribuna, como escreveu o dr. Teixeira de Mello, suplantou a lembrança de seus predecessores e fez obscurecer a fama dos pregadores seus contemporâneos; a pompa, a poesia de seu estilo, a riqueza e a novidade de sua imaginação produziam milagres ${ }^{89}$ !

Ao que parece, depois de atingir certo reconhecimento, o frei ficou cego e recolheu-se em um convento. Posteriormente, ele foi convidado a abandonar o claustro pelo imperador, que desejava sua volta à pregação. O texto machadiano é um longo elogio a essa figura, primeiro comparando-o a

85. Marmota Fluminense, n. 731, 10 jun. 1856.

86. Idem, n. 753, 31 jul. 1856.

87. Idem, ib.

88. Idem, n. 768 e 769, 4 e 6 set. 1856.

89. Augusto Sacramento Blake, Dicionário Bibliográfico Brasileiro, p. 49. 
Bossuet, depois o descrevendo como herói romântico - solitário, em uma cela escura, inspirado por Deus - e, finalmente, tentando expressar como surgia uma irradiação formidável que emanava do frei durante seus sermões.

"A Literatura durante a Restauração" Machado de Assis, que verteu para o português um trecho do original francês de Lamartine, Histoire de la Restauration ${ }^{91}$.

Do mesmo modo, "Três Tesouros Perdidos" é o conto machadiano mais antigo de que se tem notícia. Logo, é provável que essa narrativa marque sua estréia no gênero. Nela, o ficcionista constrói uma estória rápida, com uma só célula dramática, isto é, com unidade de ação bem estabelecida. Como a narrativa funda-se basicamente no diálogo, a participação do narrador reduz-se ao mínimo, particularidade que confere impressão de visualidade dinâmica ao texto. Ele focaliza os momentos finais da uma estória razoavelmente longa, embora o texto seja muito curto. Por essa técnica, que implica o respeito pela noção de unidade de tempo do teatro clássico, o narrador, focalizando o presente das personagens, traz para a frente do leitor o passado delas, que é restaurado por meio das conversas entre elas.

Trata-se de um texto muito bem construído, que explora de maneira leve um tema grave para o tempo: o adultério. Sendo essencialmente uma anedota - no sentido de narrativa com princípio, meio e fim - as personagens não possuem nome, identificando-se como Senhor F, Senhor X e Senhora E. Em breve resumo, pode-se dizer que a trama é mais ou menos a seguinte: um marido enciumado procura o suposto amante da esposa e oferece-lhe dinheiro para que ele abandone a cidade. O suposto amante, que nem conhecia a esposa do outro, pega o dinheiro e deixa o lugar. Ao retornar a casa o marido traído terá de enfrentar uma realidade não muito favorável ao seu projeto de corrigir a esposa por meio da expulsão do suposto amante. O título do conto, sendo muito irônico, faz referência aos três tesouros que talvez não sejam tão valiosos quanto se pode supor à primeira vista. A leitura atenta do texto revela bom domínio de recursos cênicos e muita aptidão para a narrativa de humor.

Em fevereiro de 1858, Paula Brito, como de costume, ofereceu aos seus leitores um mote para ser glosado:

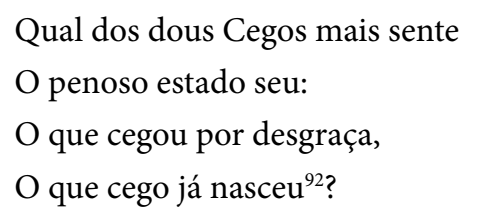

Além dos versos, o tipógrafo teceu alguns comentários sobre o tema e pediu a participação do público: "podem as pessoas, mais ou menos habilitadas, mandar-nos suas composições, quer

90. A Marmota, n. 882, 883, 886, 888, 897, 899, 905; 15, 18 e 29 set., 6 out., 6 e 13 nov., 4 dez. 1857.

91. Alphonse de Lamartine, "Livre Quinzième", Histoire de la Restauration, pp. 391-411.

92. A Marmota, n. 925, 12 fev. 1858. 
em prosa, quer em verso, que as publicaremos pela ordem em que nos chegarem à mão"93. Estavam lançadas as sementes para a polêmica "Os Cegos".

O primeiro a responder ao apelo de Paula Brito foi "Jq. Sr.", para ele: "Não ver, é uma privação; ter visto e não ver, é um castigo" ${ }^{\text {". }}$. Respondendo ao primeiro autor, que era Joaquim Serra e viria a ser grande amigo do antagonista na questão, seguiu-se a reflexão de Machado de Assis, que assinando apenas "As., iniciou da seguinte forma seu texto:

Esperávamos que alguém agitasse esta questão; e esperávamos na sombra, sem a ninguém comunicar as nossas intenções, os nossos pensamentos. Um artigo publicado no n. 929 da Marmota, decide-nos; vamos entrar na questão, expender as nossas idéias com a simplicidade e firmeza, filhas da convicção; certos da atenção e benevolência dos leitores ${ }^{95}$.

Machado defendia a idéia de que nascer cego seria mais doloroso do que perder a visão acidentalmente. Pois, no último caso, a pessoa é capaz de formar uma idéia de tudo que existe pelos "olhos do espírito e da memória", donde resulta maior dor.

Em "Réplica ao Sr. As." ${ }^{\prime 9}$, Jq. Sr. afirma que de modo algum se ofendeu com os ataques do outro autor e que escrevia novamente não para sustentar seus argumentos iniciais, mas para mostrar como eram inconseqüentes os do outro.

A polêmica não envolveu apenas As. e Jq Sr., outros autores igualmente deram suas contribuições. Como Alcipe, que concordou com Jq. Sr., anunciando: "O que perdeu a vista é mais infeliz do que o que nunca a teve. Quem nunca gozou, não pode ter saudades; e a saudade, Sr. Redator, é um dos maiores, senão o maior, dos tormentos da vida!"'97.

Machado de Assis não se conteve e lançou sua “Tréplica ao Sr. Jq. Sr.", em que passou a tratar seu opositor como "sua senhoria" (no lugar do "senhor" dos textos anteriores). No texto, afirma inicialmente que buscou refutar os argumentos falsos de seu oponente pois "receávamos que espíritos menos fortes se deixassem impressionar por uma linguagem que tão bem soube dourar uma aluvião de paradoxos" 98 . Após muitos parágrafos de dura crítica, ele fecha suas considerações dizendo que: "Se não respondemos mais em tempo é pela afluência de trabalho que nos pesa; algumas horas vagas que nos restam, ocupamos na conclusão de alguns trabalhos literários a que estas questões prejudicam um pouco"'99.

Em sua última resposta, Jq. Sr. deu-se por vencido. Concordou que seu primeiro artigo apresentava um tom mais humorístico e enfatizou que não teve qualquer intenção de chamar seu oponente As. de materialista. Em sua comunicação final, Machado comentou seu próprio triunfo:

93. Idem, ib.

94. Idem, n. 929, 26 fev. 1858, p. 1.

95. Idem, n. 931, p. 1, 5 mar. 1858.

96. Idem, n. 932, p. 2, 9 mar. 1858.

97. Idem, ib., pp. 2-3.

98. Idem, n. 934, p. 2, 16 mar. 1858.

99. Idem, ib., p. 3 . 
"Sucedeu o que esperávamos: o nosso adversário recuando passo a passo encontrou a parede a que o levaram os nossos argumentos sensatos e conseqüentes"100.

Praticamente poucos dias haviam se passado desde a divulgação do último embate pertencente à polêmica "Os Cegos", quando Machado editou o seu primeiro ensaio de crítica literária, intitulado "O Passado, o Presente e o Futuro da Literatura". Refletindo sobre a relação entre política e literatura, sobre as condições da literatura brasileira em relação à estrangeira, sobre a qualidade das traduções de seu tempo, Machado - preocupado com uma cultura em formação - mostra clara consciência acerca dos problemas da literatura nacional, assim como sobre a importância da crítica para o sistema literário brasileiro.

Envolto por essa visão, declara que "é mais fácil regenerar uma nação, que uma literatura"101. Adverte que os talentos literários daquela atualidade não são contrários ao progresso material, mas à sua exclusividade, já que podem reduzir as tendências literárias a um marasmo apático, implicando uma decadência prematura. Continuava a advertir que de cópias e traduções de romances e dramas, respectivamente, estava vivendo a literatura brasileira. Contra esses males era preciso lançar-se, já que "raros, bem raros, se têm dado ao estudo de uma forma tão importante como o romance; apesar mesmo da convivência perniciosa com os romances franceses"102. Em relação ao drama, ao teatro, afirmava: "somos o povo mais parvo e pobretão entre as nações cultas. Dizer que temos teatro é negar um fato; dizer que não o temos, é publicar uma vergonha. [...] e à parte meia dúzia de tentativas bem sucedidas, sem dúvida, o nosso teatro é uma fábula, uma utopia"103.

Machado se colocava contra a dependência cultural e conclamava que obstáculos fossem removidos, que o teatro nacional fosse criado. E, finalmente, quanto ao público que se formava para a literatura e a arte em geral, pouco sagaz a acolher talentos, afirmava que era um dever educá-lo.

Em 1859, aparecem na Marmota os textos "Bagatela", “Cousas Que São Maçantes" e "Madalena”. A primeira peça é um conto traduzido e que, em virtude de sua extensão, teve sua publicação dividida em vários números da folha. Em alguns desses trechos, logo após o texto, constava: "Trad. de M. A.. Embora essa assinatura pudesse gerar dúvidas quanto à atribuição, sabese que essa é uma colaboração machadiana devido a introdução da matéria, feita pela redação do periódico:

O Sr. Machado de Assis, cujo nome e de cujas produções literárias já os nossos leitores têm conhecimento, pelo que de sua pena se tem publicado; mimoseou-nos com a seguinte tradução, que muito lhe agradecemos, cujo trabalho não é, como o título diz, uma [Bagatela $]^{104}$

100. Idem, n. 937, p. 2, 26 mar. 1858.

101. A Marmota, n. 941, p. 1, 9 abr. 1858.

102. Idem, n. 945 , p. 1, 23 abr. 1858.

103. Idem, ib.

104. Idem, n. 1.054, p. 1, 10 maio 1859. 
Os dois outros trabalhos - "Cousas Que São Maçantes"105, texto humorístico, e "Madalena"106, chamado de "romance original", mas que pode igualmente ser entendido como conto - são de autoria de "M. de A.". Novamente a dúvida: Machado de Assis ou Moreira de Azevedo. Galante de Sousa conclui que ambos são machadianos e os insere em sua Bibliografia ${ }^{107}$, embora ele mesmo em uma nota no fim do volume expresse alguma dúvida em relação à autoria do conto ${ }^{108}$.

Jean-Michel Massa, no entanto, reluta em aceitar essas atribuições. Para ele, "Cousas Que São Maçantes" é "uma enumeração engraçada que parece, no fundo, anônima" e relativamente a "Madalena", ele sentencia: "com suas alusões ao passado do Brasil, é inteiramente no gênero dos textos que Moreira de Azevedo assinava" ${ }^{109}$. Para dar ainda mais força à sua teoria, o crítico francês encontrou uma alusão a um texto intitulado "Madalena" de Moreira de Azevedo que teria sido veiculado em uma publicação popular, Folhinhas ${ }^{110}$.

"Carniceira a Vapor", "Anedota" e "O Termômetro Parlamentar" são igualmente objeto de certa dúvida, pois todos são subscritos "M. A." O primeiro artigo é uma crônica, em que o autor descreve para seus leitores a inovação de um matadouro norte-americano que emprega máquinas a vapor para o abate de porcos, o que torna o trabalho infinitamente mais rápido e mais cruel, um “açougue dos monstros". Sua intenção, com a descrição do local e de seus métodos, é gerar reflexão sobre o progresso:

Terminemos a nossa missão de levar o leitor a visitar o estabelecimento de M. Roviello, nos Estados Unidos.

Agora resta-nos entregá-lo à liberdade de seu pensar, para que julguem até onde se tem empregado as máquinas movidas a vapor ${ }^{111}$.

"Anedota"112, como o próprio título informa, é apenas um breve relato jocoso de poucas linhas. Pelo que o presente trabalho pode apurar, o texto "O Termômetro Parlamentar" ${ }^{113}$ é uma tradução adaptada do artigo "Le Thermomètre Parlamentaire", publicado em 1857 no jornal L'Ami des Sciences ${ }^{114}$. A matéria relata uma notícia de um jornal belga, uma suposta invenção que consiste em um termômetro capaz de registrar a "temperatura real das sessões" parlamentares, o que serviria "muito para animar os bons oradores e afugentar os maçantes". Do mesmo modo, funcionaria como ferramenta para averiguar a veracidade daquilo que é publicado após os debates, pois enquanto um redator registra que determinada matéria foi muito aplaudida, outro informa que houve silêncio após o mesmo discurso.

105. A Marmota, n. 1.096, 4 out. 1859.

106. Idem, n. 1.096, 1.097, 1.098, 1.099, 1.100, 1.101, 1.102, 1.104 e 1.105; 4, 7, 11, 14, 18, 21 e 25 out.; 1 e 4 nov. 1859.

107. J. Galante de Sousa, Bibliografia de Machado de Assis, pp. 206-207.

108. Idem, ib., p. 702.

109. Jean Michel-Massa, A Juventude de Machado de Assis, p. 237.

110. Idem, ib.

111. A Marmota, n. 1.158 , p. 2, 8 maio 1860.

112. A Marmota, n. 1.159, p. 4, 11 maio 1860.

113. Idem, n. 1.164, p. 2, 29 maio 1860.

114. “Le Thermomètre Parlamentaire”, L'Ami des Sciences, 24 maio 1857, p. 336. 
Após "Idéias Vagas - A Comédia Moderna", que pode ser considerado um de seus primeiros ensaios de crítica teatral, Machado retomou brevemente o tema, na Marmota, no artigo "O Passado, o Presente e o Futuro da Literatura", comentado acima.

"O Conservatório Dramático"115, igualmente, examina o teatro brasileiro. Aparentemente, esse texto foi uma republicação, com pequenas modificações, de um artigo previamente veiculado em $O$ Espelho, em dezembro de 1859, sob o título "Idéias sobre o Teatro III - O Conservatório Dramático", terceiro ensaio crítico de uma série. O primeiro deles apresenta um diagnóstico pessimista do que se passa nos palcos e nas platéias fluminenses. Machado constata que o teatro no Brasil é muito carente de realizações significativas do ponto de vista estético, pois apenas acidentalmente surge algum talento verdadeiro. No segundo trabalho, ele inicialmente lamenta que os problemas não se encontram apenas no palco, mas também na dramaturgia. Por falta de incentivo e de apoio do público - já viciado pela imensa quantidade de traduções que lhe foram impostas apenas excepcionalmente surge um dramaturgo capaz de concorrer com os estrangeiros.

Na terceira crítica, publicada também na Marmota, Machado de Assis reforça seus argumentos em favor de uma reforma no Conservatório Dramático, no sentido de conferir-lhe a autoridade de uma censura literária. Não quer que os censores se vejam obrigados a aprovar "as frioleiras mais insensatas que o teatro entendesse qualificar de composição dramática"116. Quer que o Conservatório tenha o direito de "reprovar e proibir por incapacidade intelectual"; que se torne um "uma muralha de inteligências às irrupções intempestivas que o capricho quisesse fazer no mundo da arte, às bacanais indecentes e parvas que ofendessem a dignidade do tablado" ${ }^{117}$. Ao demandar maior autoridade para a instituição, o autor quer vê-la composta por membros inteligentes e instruídos, com vistas a proteger a platéia da má literatura, do mau teatro, além de propiciar o desenvolvimento da literatura dramática no Brasil.

Dando continuidade aos seus trabalhos ligados ao teatro, Machado publicou "Hoje Avental, Amanhã Luva"118. Trata-se de tradução adaptada da comédia francesa Chasse au Lion, de Gustave Vattier e Emile de Najac, representada pela primeira vez em Paris, no teatro Odéon, em maio de $1852^{119}$. Toda a ação da cena dramática foi transposta para o Brasil, Machado, inclusive, insere referências de sua esfera cotidiana como marcadores da vida na corte, quando uma das personagens se queixa sobre a vida na roça, dizendo: "Nem teatro lírico, nem rua do Ouvidor, nem Petalógica" ${ }^{120}$.

No número seguinte ao da publicação da última parte de "Hoje Avental, Amanhã Luva", Machado de Assis veiculou nas páginas da Marmota a "Odisséia dos Vinte Anos"121. A "fantasia em um ato" é constituída por apenas algumas cenas. Está inacabada e não foi assinada. A autoria foi indicada apenas nos índices da revista que eram remetidos mensalmente para assinantes de fora da

115. A Marmota, n. 1.142 e $1.143,13$ e 16 mar. 1860.

116. Idem, n. 1.43 , p. 3, 16 mar. 1860.

117. A Marmota, ib., p. 4.

118. A Marmota, n. 1.144, p. 2, 20 mar. 1856.

119. Jean-Michel Massa, Dispersos de Machado de Assis, p. 502.

120. A Marmota, n. 1.144, p. 2, 20 mar. 1856.

121. Idem, n. 1.147, 30 mar. 1860. 
cidade. Esse fragmento dramático consta principalmente de uma fala da personagem principal que enumera suas desgraças.

Em 1861, Machado de Assis estampou em cinco números da Marmota o texto que viria a constituir o seu primeiro volume editado em livro, "Queda Que as Mulheres Têm para os Tolos". Inicialmente, acreditou-se que se tratava de escrito original, como declara Lúcia Miguel Pereira:

[...] enumerado por Mário de Alencar entre as traduções de peças teatrais que se perderam, parece ter desafiado a argúcia do dedicado amigo de Machado de Assis. Nem é comédia, nem está perdido, e não será tão pouco tradução.

É um pequeno opúsculo crítico sobre as mulheres e a preferência que dão aos tolos sobre os homens de espírito, publicado na Marmota em 1861 e editado no mesmo ano na tipografia de Paula Brito.

Embora diga explicitamente "tradução do Sr. Machado de Assis", sem todavia declarar o nome do autor, é tão pessoal, tem tanto o aspecto de um desabafo, que parece original ${ }^{122}$.

Posteriormente, a autoria foi descoberta. "Queda é sem a menor dúvida uma tradução", confirmou Massa após encontrar o original De l'Amour des Femmes por les Souts, obra de Victor Hénaux publicada em Liège e Paris, $1859^{123}$.

Após a publicação de "Queda Que as Mulheres Têm para os Tolos", não se encontrou mais nenhum trabalho machadiano na Marmota, o que é totalmente compreensível quando se tem em conta que a revista praticamente deixou de circular consistentemente no final de 1861, após a morte de Paula Brito, e depois apresentou apenas alguns números esparsos em 1864.

122. Lúcia Miguel Pereira, op. cit., pp. 97-98.

123. Jean-Michel Massa, A Juventude de Machado de Assis, p. 319. 



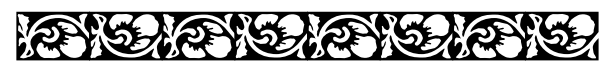

$$
\begin{aligned}
& \text { Parte } 2 \\
& \text { EdiçÃo }
\end{aligned}
$$

सम 



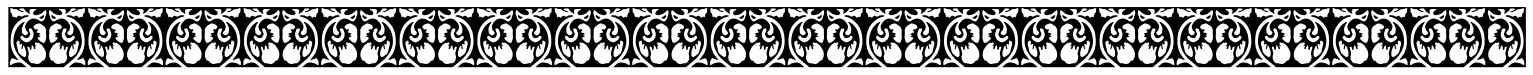 Lista dos Textos Machadianos

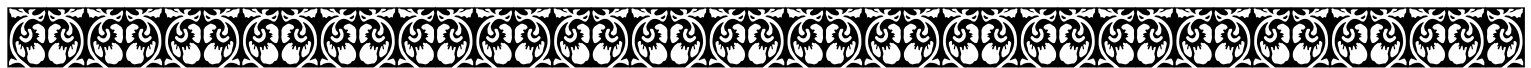

Apresenta-se, a seguir, uma relação dos textos machadianos originalmente publicados na Marmota e suas primeiras edições em volume:

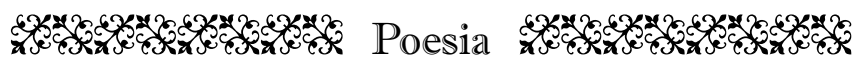

"Ela"

- Marmota Fluminense, n. 539, p. 3, 12 de janeiro de 1855

- J. Galante de Sousa (org.), Machado de Assis: Poesia e Prosa, São Paulo, Civilização Brasileira, 1957, p. 21

"A Palmeira"

- Marmota Fluminense, n. 540, p. 3, 16 de janeiro de 1855

- J. Galante de Sousa (org.), Machado de Assis: Poesia e Prosa, São Paulo, Civilização Brasileira, 1957, p. 17

"A Saudade"

- Marmota Fluminense, n. 564, p. 4, 20 de março de 1855

- Jean Michel Massa (org.), Dispersos de Machado de Assis, Rio de Janeiro, MEC/INL, 1965, p. 3

"Saudades"

- Marmota Fluminense, n. 578, p. 4, 1 de maio de 1855

- Jean Michel Massa (org.), Dispersos de Machado de Assis, Rio de Janeiro, MEC/INL, 1965, p. 4

"Júlia"

- Marmota Fluminense, n. 583, p. 4, 18 de maio de 1855

- Jean Michel Massa (org.), Dispersos de Machado de Assis, Rio de Janeiro, MEC/INL, 1965, pp. 6-7

"Lembrança de Amor"

- Marmota Fluminense, n. 587, pp. 3-4, 1 de junho de 1855

- Jean Michel Massa (org.), Dispersos de Machado de Assis, Rio de Janeiro, MEC/INL, 1965, pp. $4-6$ 
"Teu Canto"

- Marmota Fluminense, n. 600, p. 4, 15 de julho de1855

- J. Galante de Sousa (org.), Machado de Assis: Poesia e Prosa, São Paulo, Civilização Brasileira, 1957, p. 25

"A Lua"

- Marmota Fluminense, n. 601, p. 4, 17 de julho de 1855

- Jean Michel Massa (org.), Dispersos de Machado de Assis, Rio de Janeiro, MEC/INL, 1965, pp. $9-10$

"Meu Anjo"

- Marmota Fluminense, n. 603, pp. 3-4, 24 de julho de 1855

- Jean Michel Massa (org.), Dispersos de Machado de Assis, Rio de Janeiro, MEC/INL, 1965, pp. 7-9

"Um Sorriso"

- Marmota Fluminense, n. 609, p. 4, 10 de agosto de 1855

- Jean Michel Massa (org.), Dispersos de Machado de Assis, Rio de Janeiro, MEC/INL, 1965, pp. 13-15

"Como Te Amo"

- Marmota Fluminense, n. 610, p. 2, 12 de agosto de 1855

- Jean Michel Massa (org.), Dispersos de Machado de Assis, Rio de Janeiro, MEC/INL, 1965, pp. $12-13$

"Paródia"

- Marmota Fluminense, n. 611, p. 4, 14 de agosto de 1855

- Jean Michel Massa (org.), Dispersos de Machado de Assis, Rio de Janeiro, MEC/INL, 1965, p. 15

"A Saudade"

- Marmota Fluminense, n. 632, p. 3, 5 de outubro de 1855

- Jean Michel Massa (org.), Dispersos de Machado de Assis, Rio de Janeiro, MEC/INL, 1965, pp. 16-17

"No Álbum do Sr. F. G. Braga"

- Marmota Fluminense, n. 634, pp. 3-4, 9 de outubro de 1855

- Jean Michel Massa (org.), Dispersos de Machado de Assis, Rio de Janeiro, MEC/INL, 1965, pp. 20-21

"A uma Menina"

- Marmota Fluminense, n. 639, p. 4, 21 de outubro de 1855

- Jean Michel Massa (org.), Dispersos de Machado de Assis, Rio de Janeiro, MEC/INL, 1965, pp. 19-20

"O Gênio Adormecido"

- Marmota Fluminense, n. 642, pp. 3-4, 28 de outubro de 1855

- Jean Michel Massa (org.), Dispersos de Machado de Assis, Rio de Janeiro, MEC/INL, 1965, pp. $22-23$ 
"O Profeta"

- Marmota Fluminense, n. 644, p. 3, 2 de novembro de 1855

- Jean Michel Massa (org.), Dispersos de Machado de Assis, Rio de Janeiro, MEC/INL, 1965, pp. 18-19

"O Pão d’Açúcar"

- Marmota Fluminense, n. 651, p. 3, 23 de novembro de 1855

- Jean Michel Massa (org.), Dispersos de Machado de Assis, Rio de Janeiro, MEC/INL, 1965, pp. 24-25

"Soneto - A S. M. o Imperador, o Senhor D. Pedro II"

- Marmota Fluminense, n. 654, p. 1, 2 de dezembro de 1855

- Jean Michel Massa (org.), Dispersos de Machado de Assis, Rio de Janeiro, MEC/INL, 1965, p. 25

"Dormir no Campo"

- Marmota Fluminense, n. 685, p. 4, 21 de fevereiro de 1856

- Jean Michel Massa (org.), Dispersos de Machado de Assis, Rio de Janeiro, MEC/INL, 1965, pp. 11-12

"Minha Musa"

- Marmota Fluminense, n. 690, pp. 2-3, 4 de março de 1856

- J. Galante de Sousa (org.), Machado de Assis: poesia e prosa, São Paulo, Civilização Brasileira, 1957 , p. 28

“Consumatum Est!"

- Marmota Fluminense, n. 698, p. 1, 22 de março de 1856

- Jean Michel Massa (org.), Dispersos de Machado de Assis, Rio de Janeiro, MEC/INL, 1965, pp. 26-27

"Um Anjo"

- Marmota Fluminense, n. 702, p. 3, 1 de abril de 1856

- J. Galante de Sousa (org.), Machado de Assis: Poesia e Prosa, São Paulo, Civilização Brasileira, 1957, p. 31

"Cognac!"

- Marmota Fluminense, n. 707, p. 4, 12 de abril de 1856

- Afrânio Coutinho (org.), Machado de Assis: Obra Completa, Rio de Janeiro, José Aguilar, 1959, vol. III, p. 310

"Minha Mãe"

- Marmota Fluminense, n. 767, p. 4, 2 de setembro de 1856

- Afrânio Coutinho (org.), Machado de Assis: Obra Completa, Rio de Janeiro, José Aguilar, 1962, vol. III, p. 286

"Não?"

- A Marmota, n. 882, p. 2, 15 de setembro de 1857

- Jean Michel Massa (org.), Dispersos de Machado de Assis, Rio de Janeiro, MEC/INL, 1965, pp. 35-36 
"Resignação"

- A Marmota, n. 887, p. 4, 2 de outubro de 1857

- Jean Michel Massa (org.), Dispersos de Machado de Assis, Rio de Janeiro, MEC/INL, 1965, p. 36

"Amanhã"

- A Marmota, n. 893, p. 4, 23 de outubro de 1857

- Jean Michel Massa (org.), Dispersos de Machado de Assis, Rio de Janeiro, MEC/INL, 1965, pp. 47-48

"A***"

- A Marmota, n. 910, p. 2, 22 de dezembro de 1857

- Jean Michel Massa (org.), Dispersos de Machado de Assis, Rio de Janeiro, MEC/INL, 1965, p. 48

"Deus em Ti"

- A Marmota, n. 911, pp. 2-3, 25 de dezembro de 1857

- Jean Michel Massa (org.), Dispersos de Machado de Assis, Rio de Janeiro, MEC/INL, 1965, p. 49

"O Sofá"

- A Marmota, n. 915, p. 4, 8 de janeiro de 1858

- Afrânio Coutinho (org.), Machado de Assis: Obra Completa, Rio de Janeiro, José Aguilar, 1959, vol. III, p. 311

"Álvares de Azevedo"

- A Marmota, n. 916, p. 3, 12 de janeiro de 1858

- Afrânio Coutinho (org.), Machado de Assis: Obra Completa, Rio de Janeiro, José Aguilar, 1959, vol. III, p. 313

"Vai-te"

- A Marmota, n. 920, p. 4, 26 de janeiro de 1858

- Afrânio Coutinho (org.), Machado de Assis: Obra Completa, Rio de Janeiro, José Aguilar, 1959, vol. III, p. 312

"Esta Noite"

- A Marmota, n. 926, p. 4, 16 de fevereiro de 1858

- Jean Michel Massa (org.), Dispersos de Machado de Assis, Rio de Janeiro, MEC/INL, 1965, p. 49

"Reflexo"

- A Marmota, n. 936, p. 4, 23 de março de 1858

- Afrânio Coutinho (org.), Machado de Assis: Obra Completa, Rio de Janeiro, José Aguilar, 1959, vol. III, p. 314

"A Morte no Calvário"

- A Marmota, n. 939, p. 2, 2 de abril de 1858

- Afrânio Coutinho (org.), Machado de Assis: Obra Completa, Rio de Janeiro, José Aguilar, 1959, vol. III, p. 315 
"Ao Carnaval de 1860"

- A Marmota, n. 1.136, 21 de fevereiro de 1860

- Jean François Botrel, Jean-Michel Massa, Armelle Poupet, Études Luso-brésiliennes, Rennes, Faculté des Lettres et Sciences Humaines, 1966, pp. 40-41

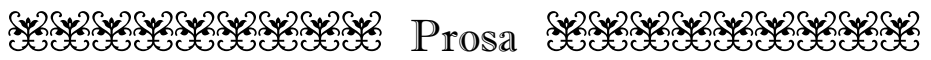

"Idéias Vagas - A Poesia"

- Marmota Fluminense, n. 731, pp. 2-3, 10 de junho de 1856

- Jean Michel Massa (org.), Dispersos de Machado de Assis, Rio de Janeiro, MEC/INL, 1965, pp. 29-31

"Idéias Vagas - A Comédia Moderna"

- Marmota Fluminense, n. 753, pp. 1-2, 31 de julho de 1856

- Jean Michel Massa (org.), Dispersos de Machado de Assis, Rio de Janeiro, MEC/INL, 1965, pp. 31-33

"Idéias Vagas - Os Contemporâneos - Mont'Alverne"

- Marmota Fluminense, n. 768, pp. 1-2, 4 de setembro de 1856

- Jean Michel Massa (org.), Dispersos de Machado de Assis, Rio de Janeiro, MEC/INL, 1965, pp. 33-35

"A Literatura durante a Restauração"

- A Marmota, n. 882 (p. 1), 883 (p. 1), 886 (p. 3), 888 (p. 4), 897 (pp. 1-2), 899 (pp. 3-4), 905 (pp. 2-3); 15, 18 e 29 de setembro de 1857, 6 de outubro de 1857, 6 e 13 de novembro de 1857, 4 de dezembro de 1857

- Jean Michel Massa (org.), Dispersos de Machado de Assis, Rio de Janeiro, MEC/INL, 1965, pp. 37-46

"Três Tesouros Perdidos"

- A Marmota, n. 914, pp. 2-3, 5 de janeiro de 1858

- Machado de Assis, Páginas Recolhidas, Rio de Janeiro, W. M. Jackson, 1937, p. 215

"Os Cegos"

- A Marmota, n. 925 (p. 3), 931 (pp. 1-2), 932 (pp. 2-3), 933 (pp. 1-2), 934 (pp. 2-3), 935 (p. 2 ) e 937 (pp. 2-3); 12 de fevereiro de 1858, 5, 9, 12, 16, 19 e 26 de março de 1858

- Jean Michel Massa (org.), Dispersos de Machado de Assis, Rio de Janeiro, MEC/INL, 1965, p. 50-67

"O Passado, o Presente e o Futuro da Literatura"

- A Marmota, n. 941 (pp. 1-2) e 945 (pp. 1-2), 9 e 23 de abril de 1858

- Afrânio Coutinho (org.), Machado de Assis: Obra Completa, Rio de Janeiro, José Aguilar, 1959, vol. III, p. 799 
"Bagatela"

- A Marmota, n. 1.054 (pp. 1-2), 1.055 (pp. 2-3), 1.056 (p. 2), 1.061 (pp. 2-3), 1.064 (pp. 1-2), 1.085 (pp. 3-4) e 1.086 (p. 2); 10, 13 e 17 de maio de 1859; 3 e 14 de junho de 1859; 26 e 30 de agosto de 1859

- Jean Michel Massa (org.), Dispersos de Machado de Assis, Rio de Janeiro, MEC/INL, 1965, pp. 85-98

"Cousas Que São Maçantes"

- A Marmota, n. 1.096, p. 4, 4 de outubro de 1859

- Jean Michel Massa (org.), Dispersos de Machado de Assis, Rio de Janeiro, MEC/INL, 1965, pp. 106-107

"Madalena"

- A Marmota, n. 1.096 (pp. 3-4), 1.097 (p. 3), 1.098 (pp. 3-4), 1.099 (pp. 3-4), 1.100 (pp. 3-4), 1.101 (pp. 2-3), 1.102 (pp. 3-4), 1.104 (pp. 2-3) e 1.105 (pp. 2-3); 4, 7, 11, 14, 18, 21 e 25 de outubro de 1859; 1 e 4 de novembro de 1859

- Jean Michel Massa (org.), Dispersos de Machado de Assis, Rio de Janeiro, MEC/INL, 1965, p. 107-129

"O Conservatório Dramático"

- A Marmota, n. 1.142 (pp. 2-3) e 1.143 (pp. 2-3), 13 e 16 de março de 1860

- Afrânio Coutinho (org.), Machado de Assis: Obra Completa, Rio de Janeiro, José Aguilar, 1959, vol. III, p. $810^{1}$

"Hoje Avental, Amanhã Luva"

- A Marmota, n. 1.144 (pp. 2-3), 1.145 (pp. 3-4) e 1.146 (pp. 1-3); 20, 23 e 27 de março de 1860

- Jean Michel Massa (org.), Dispersos de Machado de Assis, Rio de Janeiro, MEC/INL, 1965, pp. 135-149

"Odisséia dos Vinte Anos"

- A Marmota, n. 1.147, p. 3, 30 de março de 1860

- Jean Michel Massa (org.), Dispersos de Machado de Assis, Rio de Janeiro, MEC/INL, 1965, pp. 149-151

"Carniceira a Vapor"

- A Marmota, n. 1.158, pp. 1-2, 8 de maio de 1860

- Jean Michel Massa (org.), Dispersos de Machado de Assis, Rio de Janeiro, MEC/INL, 1965, pp. 152-153

"Anedota"

- A Marmota, n. 1.159, p. 4, 11 de maio de 1860

1. A matéria publicada na Marmota sob o título "O Conservatório Dramático" foi inserida na Obra Completa como uma continuação do texto "Idéias sobre o Teatro III - O Conservatório Dramático", publicado por Machado de Assis no jornal O Espelho, em 25 de dezembro de 1859. Comparando-se os textos de ambos os periódicos, pode-se notar que o artigo da Marmota é uma versão ampliada do anterior, com poucas distinções nos trechos iniciais. 
- Jean Michel Massa (org.), Dispersos de Machado de Assis, Rio de Janeiro, MEC/INL, 1965, pp. 153-154

"O Termômetro Parlamentar"

- A Marmota, n. 1.164, pp. 1-2, 29 de maio de 1860

- Jean Michel Massa (org.), Dispersos de Machado de Assis, Rio de Janeiro, MEC/INL, 1965, pp. 154-155

"Queda Que as Mulheres Têm para os Tolos"

- A Marmota, n. 1.257 (pp. 2-3), 1.258 (pp. 2-3), 1.259 (pp. 2-3), 1.260 (pp. 2-3) e 1.261 (pp. 2-3); 19, 23 e 26 de abril de 1861, 3 de maio de 1861

- Queda Que as Mulheres Têm para os Tolos, tradução de Machado de Assis, Tipografia de Francisco de Paula Brito, 1861 



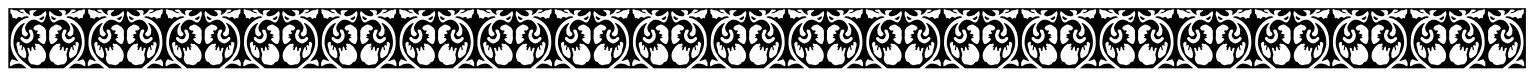 \\ Edição dos Textos Machadianos

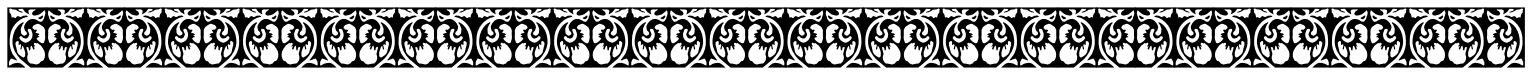

\section{Poesia}


ELA

Nunca vi, - não sei se existe

Uma deidade tão bela,

Que tenha uns olhos brilhantes

Como são os olhos dela!

F. G. Braga

Seus olhos que brilham tanto,

Que prendem tão doce encanto,

Que prendem um casto amor

Onde com rara beleza,

Se esmerou a natureza

Com meiguice e com primor.

Suas faces purpurinas

De rubras cores divinas

De mago brilho e condão;

Meigas faces que harmonia

Inspira em doce poesia

Ao meu terno coração!

Sua boca meiga e breve,

Onde um sorriso de leve

Com doçura se desliza,

Ornando purpúrea cor,

Celestes lábios de amor

Que com neve se harmoniza.

Com sua boca mimosa

Solta voz harmoniosa

Que inspira ardente paixão,

Dos lábios de Querubim

Eu quisera ouvir um - sim -

Pra alívio do coração!

Vem, ó anjo de candura,

Fazer a dita, a ventura

De minhalma sem vigor;

Donzela, vem dar-lhe alento, 
Faz-lhe gozar teu portento,

"Dá-lhe um suspiro de amor!"

Assis

\section{A Palmeira \\ O. D. C.}

A Francisco Gonçalves Braga

Como é linda e verdejante

Esta palmeira gigante

Que se eleva sobre o monte!

Como seus galhos frondosos

Selevam tão majestosos

Quase a tocar no horizonte!

Ó palmeira, eu te saúdo,

Ó tronco valente e mudo,

Da natureza expressão!

Aqui te venho ofertar

Triste canto, que soltar

Vai meu triste coração.

Sim, bem triste, que pendida

Tenho a fronte amortecida

Do pesar acabrunhada!

Sofro os rigores da sorte,

Das desgraças a mais forte

Nesta vida amargurada!

Como tu amas a terra

Que tua raiz encerra,

Com profunda discrição;

Também amei da donzela

Sua imagem meiga e bela,

Que alentava o coração.

Como ao brilho purpurino 
Do crepusc'lo matutino

Da manhã o doce albor;

Também amei com loucura

Essalma toda ternura

Dei-lhe todo o meu amor!

Amei!... mas negra traição

Perverteu o coração

Dessa imagem da candura!

Sofri então dor cruel,

Sorvi da desgraça o fel,

Sorvi tragos d'amargura!

Adeus, palmeira! ao cantor

Guarda o segredo de amor;

Sim, cala os segredos meus!

Não reveles o meu canto,

Esconde em ti o meu pranto

Adeus, ó palmeira!... adeus!

Rio de Janeiro, 6 de janeiro de 1855

Assis

\section{A SAUdAde}

O. D. e C. ao meu primo o Sr. Henrique José Moreira

Meiga saudade! - Amargos pensamentos

A mente assaltam de valor exausta,

Ao ver as roxas folhas delicadas

Que singelas te adornam.

Mimosa flor do campo, eu te saúdo;

Quanto és bela sem seres perfumada!

Que te inveja o jasmim, a rosa e o lírio

Com todo o seu perfume?

Repousa linda flor, num peito f'rido, 
A quem crava sem dó a dor funesta,

O horrível punhal, que fere e rasga

Um débil coração.

Repousa, linda flor, vem, suaviza

A frágua devora um peito ansioso,

Um peito que tem vida, mas que vive

Envolto na tristeza!...

Mas não... deixo-te aí causando inveja;

Não partilhes a dor que me consome,

Goza a ventura plácida e tranqüila,

Mimosa flor do campo!

Por - J. M. M. de Assis

SAUdAdES

Ao Ilmo. Sr. F. G. Braga

Vai oh! meu saudoso canto

Dizer um nome - Saudade!

F. G. Braga

Recebe, ó Braga, o meu canto,

Que eu cá de longe t’envio;

São orvalhadas do pranto

Secas flores do estio;

É a prova da lealdade

Duma constante amizade.

Recebe, que o pensamento

Tenho em Deus, na pátria em ti;

Das privações no tormento

Do tempo, que te não vi:

São flores, dá-lhe cultura,

Dá-lhe o porvir da ventura.

No mar do mundo enganoso 
Há procelas, há bonanças;

Procela, é quando saudoso

Vive um peito co'as 'speranças;

Bonança, é quando amizade

Goza paz e f'licidade.

Sofri procela; meus olhos

Te não viram com ventura;

Soçobrei ante os escolhos

Da desgraça e desventura;

A dor ceifou da esperança

A flor que a saudade alcança.

Cruel ausência! que dias

Tão amargos não passei;

Que imenso mar d’alegrias

Ter contigo não sonhei!

Tudo quimera, ilusão,

Bem sabia o coração!

Não viçavam minhas flores,

Era escuro o firmamento;

Não via nele os fulgores

Só via meu sofrimento,

Só via pranto, saudade;

Era a pura realidade.

Saudade! bebi na taça

O fel amargo da dor;

Quis horrífica desgraça

Que te não visse, cantor;

Dei de rojo o corpo ao leito,

Sufoquei a dor no peito!

Adeus... não pode minh'alma

Entre suspiros cantar;

Minha dor somente acalma

Se ouvir teu doce trovar,

Que entre o fel, que o peito traga,

Um nome me adoça é - BRAGA - 
Rio de Janeiro, 25 de fevereiro de 1855

J. M. M. de Assis

\section{JÚLIA}

Teu rosto meigo e singelo

Tem do Céu terno bafejo.

Tu és a rosa do prado

Desabrochando ao albor;

Abrindo o purpúreo seio,

Abrindo os cofres de amor.

Tu és a formosa lua

Percorrendo o azul dos céus,

Retratando sobre a linfa

Os seus alvacentos véus.

Tu és a aurora formosa

Quando d’além vem surgindo;

E que se ostenta garbosa

Áureas flores espargindo.

Tu és perfumada brisa

Sobre o prado derramada,

Que goza os doces sorrisos

Da formosa madrugada.

Tua candura e beleza

Tem de amor doce expressão;

És um anjo, minha Júlia,

Donde nasce a inspiração.

Quando a terra despe as galas

E os mantos da noite veste,

Vejo brilhar tua imagem

Lá na abóbada celeste. 
Nela vejo as tuas graças,

Nela vejo um teu sorriso,

Nela vejo um volver dolhos

Nascido do paraíso.

És, ó Júlia, meiga virgem

Que temente ora ao Senhor;

São teus olhos duas setas,

O teu todo é puro amor.

Maio de 1855

J. M. M. de Assis

\section{LEMBRANÇA DE AMOR}

Vem, ó Júlia, vem ao prado

Vem colher mimosas flores,

Para ornar teu níveo seio,

Onde vivem os amores.

Olha o rubor desta rosa

Que simboliza a paixão;

Toma-a, põe-na, minha Júlia,

Põe-na sobre o coração.

Não temas que da roseira

Longe fique emurchecida;

Junto a ti tudo é brilhante,

Junto a ti tudo tem vida.

Olha a cândida pureza

Deste tão alvo jasmim,

Linda flor que brilha, impera

Que dá beleza ao jardim. 
Põe também junto da rosa

Esta flor de alabastrino,

Que doce contraste opera

Junto ao alvo, o purpurino!

Fresca e bela és como a rosa,

Como o jasmim tens pureza,

Teus dotes são dotes celestes,

Que te deu a natureza.

Olha, vê, querida Júlia,

este lindo amor perfeito,

Bela flor que simboliza

Da nossa paixão o efeito.

Toma-a, põe-na junto à rosa, Junto também do jasmim,

Transforma teu seio excelso

No mais formoso jardim.

Que doce junção não faz

Com essas a tenra flor!

Da paixão e da candura

Só nasce um perfeito amor.

Se algum dia nosso afeto

For por alguém perturbado,

E longe um doutro estas prendas

Lembrarem teu bem amado;

Conserva sempre em teu seio

Estas prendas - puro amor;

Seja querida lembrança

Do nosso extremado ardor.

Maio 10, de 1855

J. M. M. de Assis 


\section{Teu Canto}

A uma italiana

É sempre nos teus cantos sonorosos

Que eu bebo inspiração

Do Autor

Tu és tão sublime

Qual rosa entre as flores

De odores

Suaves;

Teu canto é sonoro

Que excede ao encanto

Do canto

Das aves.

Eu sinto nest'alma,

Num meigo transporte,

Meu forte

Dulçor;

Se soltas teu canto

Que o peito me abala,

Que fala

De amor.

Se soltas as vozes

Que podem à calma,

Minh'alma

Volver;

Minh'alma se enleva

Num gozo expansivo

De vivo

Prazer.

Donzela, esta vida

Se eu tanto pudera,

Quisera

Te dar;

Se um beijo eu pudesse

Ardente e fugace 
$\mathrm{Na}$ face

Pousar.

29 de junho de 1855

J. M. M. d'Assis.

\section{A LUA}

Poesia oferecida ao meu amigo o Ilmo. Sr.

\section{F. A. Vaz da Mota}

Vem acolher meu suspiro, Ver como por ti respiro,

Que quero deste retiro

Me leves um - ai - a Deus!...

(E. D. Vilas-Boas - A Lua)

É noite: fulgura a lua

E esparge à campina amena

Branda lua;

Contempla a beleza sua

Sobre a linfa, que serena

Geme a flux.

Em sua fronte marmórea

Tem estampada a beleza

Lá do céu;

Sua luz é merencória,

Cobre-lhe a tez da pureza

Branco véu.

Lá no campo, sobre as flores,

Dardeja seus brandos raios

Cor de prata,

Parece falar amores

Em seus cândidos desmaios

Que arrebatam.

Como a sua luz é pura

Sobre as águas tão serenas

Deste lago! 
Como a taça da doçura

Me faz libar toda, apenas

$$
\text { Dum só trago! }
$$

Longe as dores: vibro a lira

Descanto amoroso endeixa

De minh'alma

Do coração que suspira

Já não solto triste queixa:

Tenho calma.

Meiga lua, tu és pura;

São divinos teus encantos;

Teu sorrir;

Tem candor a tua alvura;

Tu me dás prazeres santos

Num luzir.

Tu me inspiras; és meu Nume,

E eu sou de teus encantos

\section{O Cantor;}

Se brilhas no etéreo cume

Cessam meus ardentes prantos

Cessa a dor.

Cessa a dor se com teu brilho

Tu me afagas fulgurante

Na soidão;

Se teu encanto partilho

Dás prazer ao meu amante

Coração.

Rio de Janeiro, 27 de junho de 1855

J. M. M. d'Assis

\section{Meu AnJo}

Um anjo desejei ter a meu lado...

E o anjo que sonhei achei-o em ti!...

C. A. de Sá

És um anjo d'amor - um livro d'ouro, 
Onde leio o meu fado

És estrela brilhante do horizonte

Do Bardo enamorado

Foste tu que me deste a doce lira

Onde amores descanto

Foste tu que inspiraste ao pobre vate

D’amor festivo canto;

É sempre nos teus cantos sonoros

Que eu bebo inspiração,

Risos, gostos, delícias e venturas

Me dá teu coração.

É teu nome que trago na lembrança

Quando estou solitário,

Teu nome a oração que o peito reza

D’amor um santuário!

$E$ tu que és minha estrela, tu que brilhas

Com mágico esplendor,

Escuta os meigos cantos de minh'alma

Meu anjo, meu amor.

Quando sozinho, na floresta amena

Tristes sonhos modulava,

Não em lira d'amor - na rude frauta

Que a vida me afagava,

Tive um sonho damor; sonhei que um anjo

Estava ao lado meu,

Que com ternos afagos, com mil beijos

Me transportava ao céu.

Esse anjo d'amor descido acaso

De lá do paraíso,

Tinha nos lábios divinais, purpúreos,

Amoroso sorriso;

Era um sorriso que infundia n'alma

$\mathrm{O}$ mais ardente amor;

Era o reflexo do formoso brilho

Da fronte do Senhor;

E esse anjo sonhado, cara amiga,

A quem consagro a lira,

És tu por quem minhalma sempre triste

Amorosa suspira! 
Quando contigo, caro bem, d'aurora

O nascimento vejo

Em um berço florido, e de ventura

Gozarmos terno ensejo;

Quando entre mantos d'azuladas cores

A meiga lua nasce

E num lago de prata refletindo

Contempla a sua face;

Quando num campo verdejante e ameno,

Dum aspecto risonho,

Ao lado teu passeio; eu me recordo

Do meu tão belo sonho,

E lembra-me esse dia venturoso

Em que a vida prezei,

Que vi teus meigos lábios me sorrirem,

Que logo te adorei!

Nesse dia sorriu a natureza

Com mágico esplendor,

Parecia augurar ditoso termo

Ao nosso puro amor.

E te juro, anjo meu, ditosa amiga,

Por tudo que há sagrado,

Que esse dia trarei junto ao teu nome

No meu peito gravado.

$E$ tu que és minha estrela, tu que brilhas

Com mágico esplendor,

Escuta os meigos cantos de minh'alma

Meu anjo, meu amor!

Rio, 21 de junho de 1855

J. M. M. d'Assis 


\section{UM SORRISO}

Em seus lábios um sorriso

É a luz do paraíso.

Garrett

Não sabes, virgem mimosa,

Quanto sinto dentro d'alma

Quando sorris tão formosa

Sorriso que traz-me a calma;

Brando sorriso d'amores

Que se desliza entre as flores

De teus lábios tão formosos;

Doce sorriso que afaga

Do peito a profunda chaga

De tormentos dolorosos.

Quando o diviso amoroso

Por sobre as rosas vivaces

Torno-me louco, ansioso,

Desejo beijar-te as faces;

Corro a ti... porém tu coras

Logo súbito descoras

Arrependida talvez...

$\mathrm{Na}$ meiga face t'imprimo

Doce beijo, doce mimo

Da paixão que tu bem vês.

Eu gosto, meiga donzela,

De ver-te sorrindo assim

Semelhas divina estrela

Que brilhas só para mim

És como uma linda rosa

Desabrochando mimosa

Ao respiro da manhã:

És como serena brisa

Que no vale se desliza

Seu mais terno e doce afã. 
O brando favônio ameno;

Da fonte o gemer sentido;

Da lua o brilho sereno

Sobre um lago refletido

Não tem mais doces encantos

Que, sobre os puníceos mantos

Dos lábios teus um sorriso,

Sorriso que amor me fala

Como d'alva o encanto, a gala

Quando serena a diviso.

Sorri, sorri, que teu sorriso brando

Minhas penas acalma;

É como a doce esp'rança realizada

Que as ânsias desvanece!

E se queres em troca dum sorriso

Uma prova de amor

Vem pra perto de mim mescuta ao peito

$\mathrm{Na}$ face um beijo toma...

Rio de Janeiro, 4 de agosto de 1855

J. M. M. d'Assis

\section{Como Te Amo}

Eu amo-te como a florinha

Quer bem à serena brisa,

Quando meiga se desliza

Sobre campina relvosa;

Eu te amo como a rola

Ama o bosque solitário

Onde vai por seu fadário

Carpir-se com voz chorosa.

Eu amo-te como o zéfiro

Ama um flórido jardim

Como a Deus um serafim,

Como o sol azul dos Céus; 
Eu amo-te como o Vate

Ama rutilante estrela,

Que é imagem da donzela,

Objeto d'amores seus.

Eu te amo com ternura

Como ama o pobre nauta

Merencória e rude frauta;

Como o zagal o arrabil,

Eu te amo com afeto

Qual da noite o lindo astro

Em seu carro d'alabastro

Ama o Céu da cor d'anil.

"Eu amo-te como a aurora"

Entre manto auri-rosado

Ama o lírio que orvalhado

Retrata d'alva o esplendor;

Eu amo-te com ternura

Como a donzela formosa

Ama a nota sonorosa

Da harpa do trovador

Eu te amo com afeto

Como a donzela ama as flores;

Porque tu és o objeto

De meus plácidos amores.

Rio, 1 de agosto de 1855

J. M. M. d'Assis

\section{PARÓDIA}

Se eu fora poeta de um estro abrasado

Quisera teu lindo semblante cantar;

Gemer eu quisera bem junto a teu lado,

Se eu fora uma onda serena do mar; 
Se eu fora uma rosa de prado relvoso,

Quisera essa coma, meu anjo, adornar;

Se eu fora um anjinho de rosto formoso

Contigo quisera no espaço voar;

Se eu fora um astro no céu engastado

Meu brilho, quisera pra ti só brilhar;

Se eu fora um favônio de aromas pejado

Por sobre teu corpo me iria espraiar;

Se eu fora das selvas umave ligeira

Meus cantos quisera pra ti só trinar;

Se eu fora um eco de nota fagueira

Fizera teu canto no céu ressoar;

Mas eu não sou astro, poeta, ou anjinho.

Nem eco, favônio, nem onda do mar;

Nem rosa do prado, ou ave ligeira;

Sou triste que a vida consiste em te amar.

Rio de Janeiro, 5 de agosto do 1855

J. M. M. d'Assis

\section{A SAUdAde}

Saudade! ó casta virgem, Qu'inspiraste a Bernardim,

Nos meus dias de tristeza

Consolar tu vens a mim.

F. G. Braga

Saudade! d'alma ausente, o acerbo impulso,

Mágico, doce sentimento d'alma

Místico enleio que nos cerra doce

O espírito cansado!... Oh! saudade,

Para que vens pousar-te envolta sempre

Em tuas vestes roxeadas, tristes,

Nas débeis cordas de minh'harpa débil?!... 
Doce chama me ateias dentro d'alma,

Meiga esperança que me nutre em sonhos

De cândida ventura!... Ó saudade,

D’alma esquecida o despertar pungente;

Doce virgem do Olimpo rutilante,

Que co’a taça na destra à terra baixas

$\mathrm{E}$ o agro, doce líquido entornando

Em coração aflito, meiga esparges

Indizível encanto, que deleita,

Melancólicas horas num letargo

D’espírito cansado, d'alma aflita,

Que plácida flutua extasiada,

$\mathrm{Na}$ etérea região, morada excelsa

Do sidéreo esplendor que a mente inflama;

Tu que estreitas minhalma, em doce amplexo

Preside ao canto meu, ao pranto, às dores.

Quando a noite vaporosa,

Silenciosa,

Cinge a terra em manto denso;

Quando a meiga, a clara Febe.

Cor de neve

Branda corre o espaço imenso.

Quando a brisa suspirando,

Sussurrando,

Move as folhas do arvoredo,

Qual eco dum som tristonho

Que num sonho

Revela ao Vate um segredo.

Quando, enfim, se envolve o mundo

Num profundo

Silêncio que ao Vate inspira,

Vens a meu lado sentar-te,

Vens pousar-te

Nas cordas de minha lira.

E me cinges num abraço

Doce laço

Que se aperta mais, e mais; 
E depois entre os carinhos,

Teus espinhos

Em minh'alma repassais!

Entre a melancolia

De poesia

Me dais santa inspiração

Da alma solto uma endeixa,

Triste queixa,

Triste queixa, mas em vão.

Na morada estelífera vagueia

Minh'alma em teus carinhos absorta.

D’aéreo berço, sobre ameno encosto

Adormece de amor, junto a teu lado,

E geme melancólica... e suspira,

Té que desponte da ventura a aurora!

Rio, 1 de setembro de 1855

J. M. M. de Assis

\section{No Álbum do Sr. F. G. Braga}

\section{Pago ao gênio um tributo merecido \\ Que a gratidão me inspira;}

Fraco tributo, mas nascido d'alma.

MAG. Saudades

Qual descantou na lira sonorosa

O terno Bernardim com voz suave;

Qual em tom jovial cantou Elmano

Brandas queixas de amor, tristes saudades

Que em seus cantares mitigou; oh! Vate,

Assim da lira tu, ferindo as cordas,

Cantas amores que em teu peito nutres,

Choras saudades que tu'alma sente;

Ou ergues duradouro monumento

À cara pátria que distante choras. 
Do Garrett divino - o Vate excelso

Renasce o brilho inspirador das trovas,

Das mimosas canções que o mundo espantam

Nesse canto imortal sagrado aos manes

Do famoso Camões, cantor da Lísia ${ }^{1}$

São carmes que te inspira o amor da Pátria.

Nele relatas em divinos versos

O exímio Trovador, a inteira vida

Já no campo de Marte; já no cume

Do Parnaso bradando aos povos todos

Os feitos imortais da lusa gente!

Nessa epopéia, monumento excelso

Que em memória do Vate à pátria ergueste,

Ardente se desliza a etérea chama,

Que de Homero imortal aos sucessores

Na mente ateia o céu com forte sopro!

Euterpe, a branda Euterpe nos teus lábios

Da taça d'ouro, derramando o néctar

Deu-te a doce com que outrora

Extasiou Virgílio ao mundo inteiro!

"Empunha a lira d'ouro, e canta altivo

Um Tasso em ti se veja - o estro excelso

De Camões imortal, te assoma à mente;

E de verde laurel cingida a fronte

Faz teu nome soar na voz da fama!"

Foram estas frases com que Apolo

Poeta te fadou quando nasceste,

E em doce gesto te imprimiu na fronte

Um astro de fulgor, que sempre brilha!

Ah! que não possam estes pobres versos, Que náureas folhas de teu belo livro Trêmulo de prazer c'oa destra lanço, Provar-te o assombro, que ao ouvir-te sinto!

Embora!... entre os arquejos de minh'alma

1. Um belo poema do Sr. Braga intitulado - Camões [N. do A.]. 
Do opresso coração entre os suspiros

As brandas vibrações da pobre lira

Vão em tua alma repetir sinceros

Votos dest'alma que te prove o assombro

Que sinto ao escutar-te as notas d'harpa!

Rio de Janeiro, 1855

J. M. M. d'Assis

\section{A uma Menina}

\section{La esencia de las flores \\ Tu dulce aliento sea.}

(Quintana)

Desabrochas ainda; tu és bela

Como a flor do jardim;

És doce, és inocente, como é doce

Divino Querubim.

Nas gotas da pureza inda se anima

A tu’alma infantil;

Não te nutre inda o peito da malícia

Mortífero réptil.

Quando sorris trasbordam de teus lábios

As gotas d'inocência;

No teu sorriso se traduz o encanto

Da tua pura essência.

És anjo, e são os anjos que confortam

Os tormentos da vida;

Vive, e não haja em teu semblante a prova

De lágrima vertida!

Rio, 19 de setembro de 1855

J. M. M. d'Assis 


\section{O GÊNIO AdORMECIDO}

O. D. C. ao Ilmo. Sr. Antônio Gonçalves Teixeira e Sousa

Do Grego Vate expande-se a harmonia

Em teus sonoros carmes! Na harpa d'ouro

Do sacro Apolo, Trovador, dedilhas

Doces cantos que o espírito arrebata

Ao recinto celeste!

Em cit'ra de marfim, com fios d'ouro

Cantaste infante, para que mais tarde

A fama ativa as tubas embocando

Com voz imensa proclamasse aos mundos

Um Gênio Americano!

E tu dormes, Poeta?! Da palmeira

No verde tronco penduraste a lira.

Após nela entoar linda epopéia,

Que mau condão funesto à nossa pátria

Faz soporoso o Vate!

Vate! Vate!... Que morre harmonioso!

Semelha um som ao respirar das brisas

Nas doces cordas do alaúde d’ouro

Pendurado no ramo da palmeira,

Que sombreia o regato!

Desperta, ó Vate, e libertando o estro

Desprende a voz, e os cânticos divinos;

Deixa entornar-se em teus ungidos lábios

Como a ribeira deslizando o corpo

Cercado de boninas.

Sim, ó Vate, o teu canto é tão sonoro

Como os sons da Seráfica harmonia

Dos sonorosos cantos sublimados

Do doce Lamartine - o Bardo excelso,

Da França o belo Gênio!

Toma a lira de novo, e um canto vibra, 
E depois ouvirás a nossa terra

Orgulhosa dizer: - Grécia, emudece,

Dos Vates berço, abrilhantado surge

O Gênio adormecido!

Rio - outubro de 1855

J. M. M. d'Assis

\section{O Profeta}

(fragmento)

ungido crente,

Alma de fogo, na mundana argila.

M. A. A. Azevedo

Do sacro templo, sobre as negras ruínas

Lá medita o profeta

Com fatídica voz, dizendo aos povos

Os decretos de um Deus;

Ao rápido luzir do raio imenso

Traçando as predições.

Dos soltos furacões, libertas asas

Adejam sobre a terra;

Do sacro templo em denegridos muros

Horríssono gemendo

Lá fende o seio de pesadas nuvens

$\mathrm{O}$ fulminoso raio

Sinistro brilho, que o terror infunde.

Que negro e horrível quadro!

Propínquo esboço da infernal morada!...

E o profeta ergue a fronte, a fronte altiva

Cheio de inspiração, de vida cheio;

Revolvem-se na mente escandescida

Inspiradas idéias que Deus cria

Nesse cofre que encerra arcanos sacros;

Revolvem-se as idéias, pensamentos

Que num lampejo abrangem as idades 
Rápidas aglomeradas

Nesse abismo que os séculos encerra!

Profeta, em que meditas

O espírito de Deus que te revela?

Um novo cataclismo,

Que a terra inunde e a humanidade espante?

De guerras sanguinosas longa série?

A desgraça talvez dum povo inteiro?

Enviado de Deus, conta-me os sonhos

Que te revelam do futuro as sortes

Quando absorto em sacros pensamentos

A fronte reclinando tu dormitas

Essas visões que à hora do silêncio

Quando reina o pavor, e as trevas reinam

Os céus ensaiam quo porvir revelam:

E quando é bela a noite, quando brilha

A prateada lua

Lâmpada argêntea, que alumia as trevas

Quando fulguram meigos

Formosos, belos astros, que semelham

Longa série de luzes

Que a lousa aclaram do sepulcro imenso:

$\mathrm{O}$ que te inspira o céu?

Já sossega a tormenta; - refreados

Jazem mudos os ventos; só a brisa

Plácida expele as condensadas nuvens;

Envolta em negro véu lá brilha acaso

Medrosa estrela que sorri medrosa:

'Stá muda a atmosfera! Lá se ergue

De súbito o profeta, (sacra gota

Na mente lhe verteu do Eterno a destra).

Do Supremo Arquiteto o mando grava

No extenso muro do arruinado templo!...

Rio de Janeiro, 11 de setembro de 1855

J. M. M. d'Assis 


\section{O PÃO D’AÇúCAR}

Salve, altivo gigante, mais forte

Que do tempo o cruel bafejar,

Que avançado campeias nos mares,

Seus rugidos calado a escutar.

Quando Febo ao nascente aparece

Revestido de gala e de luz,

Com seus raios te inunda, te beija,

Em tua fronte brilhante reluz.

Sempre quedo, com a fronte inclinada,

Acoberto dum véu denegrido;

Tu pareces gigante que dorme

Sobre as águas do mar esquecido.

És um rei, sobranceiro ao oceano,

Parda névoa te cobre essa fronte,

Quando as nuvens baixando em ti pairam

Matizadas do sol no horizonte.

Fez-te o Eterno surgir dentre os mares

C'uma frase somente, c'um grito;

Pôs-te à fronte gentil majestade,

Negra fronte de duro granito.

Ruge o mar, a procela te açoita,

Feros ventos te açoitam rugindo;

O trovão lá rebrama furioso,

E impassível tu ficas sorrindo.

E da fouce do tempo se solta

Sopro fero de breve eversão,

Quer feroz te roubar para sempre;

Tu sorris, qual sorris ao trovão.

Salve, altivo gigante, mais forte

Que do tempo o cruel bafejar, 
Que avançado campeias nos mares,

Seus rugidos calado a escutar.

Rio, 30 de outubro de 1855

J. M. M. d'Assis

\section{Soneto a S. M. o Imperador, o Senhor \\ D. PEDro II}

Nesse trono, Senhor, que foi erguido

Por um povo já livre, e sustentado

Por ti, que alimentando as leis, o estado

Hás na História teu Nome engrandecido;

Nesse trono, Senhor, onde esculpido

Tem a destra do Eterno um nome amado,

Vês nascer este dia abrilhantado

Sorrindo a ti, Monarca esclarecido!

Eu te saúdo neste dia imenso!

Da Clemência, Justiça e sã Verdade

Queimando às piras perfumoso incenso!

Elevado aos umbrais da imensidade

Terás fama, respeito, e amor intenso,

Um Nome transmitindo à Eternidade!

Rio de Janeiro, 2 de dezembro de 1855

Pelo seu reverente súdito

J. M. M. d'Assis

\section{Dormir NO CAMPO}

Ao terno suspirar do arroio brando,

Quanto é belo o repouso em campo ameno! 
Em noite de verão, que a brisa geme,

Em noite em que o luar brilha sereno!

Acorda-se alta noite: no silêncio

Envolta jaz a terra adormecida;

Verseja-se um minuto, à noite, à lua,

E torna-se a dormir... Que bela vida!...

Se se ouve o piar d'ave noturna

Solta-se a ela mesma um doce canto,

Lança-se extremo olhar da lua ao brilho

E torna-se a dormir sob seu manto.

Não há vida melhor por certo; eu juro

Não a trocar por outra inda que bela;

Não há nada no mundo mais sublime

Que um homem contemplar a sua estrela.

É belo o despertar, abre-se os olhos

Suavemente as pálpebras se erguendo

Divisa-se a serena e branda aurora,

Que vai rubra madeixa desprendendo.

Senta-se abrindo os olhos, bocejando,

Lançando à banda a destra agarra a lira,

Preludia-se um canto, um canto d'alma

E o terno coração terno suspira.

Erguendo-se sacode a véstia, as calças,

Compõe-se o vestuário com asseio.

E cuidadoso segurando a lira,

Vai-se dar pelo campo almo passeio.

Procura-se depois uma serrana

E se tece uma endeixa após um beijo

(Que é de beijos que o vate se sustenta)

Embora à face ardente assome o pejo. 
Não há vida melhor, por certo, eu juro

Não a troco por outra, inda que bela;

Não há nada no mundo mais sublime

Que amar-se alguma rústica donzela!

Rio, 19 de julho de 1855

J. M. M. d'Assis

\section{Minha Musa}

A Musa, que inspira meus tímidos cantos,

É doce e risonha, se amor lhe sorri;

É grave e saudosa, se brotam-lhe os prantos,

Saudades carpindo, que sinto por ti.

A Musa, que inspira-me os versos nascidos,

De mágoas que sinto no peito a pungir,

Sufoca-me os tristes e longos gemidos,

Que as dores que oculto me fazem trair.

A Musa, que inspira-me os cantos de prece,

Que nascem-me d'alma, que envio ao Senhor.

Desperta-me a crença, que às vezes 'dormece

Ao último arranco de esp’ranças de amor.

A Musa, que o ramo das glórias enlaça,

Da terra gigante - meu berço infantil,

De afetos um nome na idéia me traça,

Que o eco no peito repete: - Brasil!

A Musa, que inspira meus cantos é livre,

Detesta os preceitos da vil opressão,

O ardor, a coragem do herói lá do Tibre,

Na lira engrandece, dizendo: - Catão! 
O aroma da esp'rança, que n'alma recende,

É ela que aspira, no cálix da flor;

É ela que o estro na fronte me acende,

A Musa que inspira meus versos de amor!

Rio, 22 de fevereiro de 1856

J. M. M. d'Assis

\section{Consumatum Est! ${ }^{2}$}

Povos, curvai-vos

A redenção do mundo consumou-se.

João de Lemos

I

$\mathrm{Na}$ treva sombria de sacra tristeza,

Gemendo se envolvem a terra e os céus,

$\mathrm{E}$ a alma do crente num cântico acesa,

Revolve na idéia, suplício de um Deus.

Recorda a cidade que outrora folgando

Sorria descrente de um Deus à paixão,

E hoje proscrita lá dorme escutando

Do Eterno a palavra que diz: "Maldição!"

De Cristo os martírios, a dor tão intensa

De santa humildade, são provas fiéis,

E as gotas de sangue, as bases da crença,

Da crença que fala nos povos, nos reis!

Entremos no Templo, e um cântico d’alma

Em ondas de incenso mandemos aos céus,

E ao mestre divino, de mártir co’a palma,

Curvados oremos num cântico a Deus!

II

2. O título está conforme o original publicado na Marmota, no entanto o correto seria "consummatum". 
Senhor! entre apupadas dos algozes

Foste levado ao cimo do Calvário

Para a morte sofrer!

De Deus ouviste as tão sagradas vozes,

Cheio de sangue envolto em um sudário

Tu quiseste morrer!

Quiseste, porque assim se revogava

Da pena eterna a tão fatal sentença

Que o pecado traçou!

E o sangue que teu corpo derramava

Era alto preço e animava a crença,

Que o pecado abismou!

E caminhaste ao Gólgota, levando

A cruz onde por nós foste cravado:

Cruenta imolação!

O sangue teu em jorros borbotando,

E teu corpo de açoutes tão chagado,

Sem dó, sem compaixão!

Oh! Cristo! e tu sofreste tais injúrias!

Foste arrastado ao cimo do Calvário,

Morto a plebe te quis!

Não quiseste embargar o ardor das fúrias,

Tu, cuja voz a Lúcifer tartáreo

Curva a negra cerviz!

"Perdoai-lhes, Senhor!" disseste, quando

Quase a expirar os olhos levantaste

Ao céu anuviado,

E já da morte gélido arquejando,

Com fraca e triste voz pronunciaste:

“Tudo está consumado!”

III

E o mundo remiu-se! De Deus à morada,

Gozando outra vida, se eleva Jesus!...

Cristãos! penetremos a casa sagrada, 
E a Cristo adoremos em torno da cruz!

Semana Santa de 1856

M. M. d'Assis

UM ANJO

(À memória de minha irmã)

Se deixou da vida o porto

Teve outra vida nos céus.

A. E. Zaluar

Foste a rosa desfolhada

Na urna da eternidade,

Pra sorrir mais animada,

Mais bela, mais perfumada

Lá na etérea imensidade.

Rasgaste o manto da vida,

E anjo subiste ao céu

Como a flor enlanguecida

Que o vento pô-la caída

E pouco a pouco morreu!

Tu'alma foi um perfume

Erguido ao sólio divino;

Levada ao celeste cume

C'os Anjos oraste ao Nume

Nas harmonias dum hino.

Alheia ao mundo devasso,

Passaste a vida sorrindo;

Derribou-te, ó ave, um braço,

Mas abrindo asas no espaço

Ao céu voaste, anjo lindo.

Esse invólucro mundano

Trocaste por outro véu; 
Deste negro pego insano

Não sofreste o menor dano

Que tu’alma era do Céu.

Foste a rosa desfolhada

Na urna da eternidade

Pra sorrir mais animada,

Mais bela, mais perfumada

Lá na etérea imensidade.

Rio, outubro de 1855

J. M. M. d'Assis

\section{Cognac!...}

Vem, meu Cognac, meu licor d'amores!...

É longo o sono teu dentro do frasco;

Do teu ardor a inspiração brotando

O cérebro incendeia!...

Da vida a insipidez gostoso adoças;

Mais val um trago teu que mil grandezas;

Suave distração - da vida esmalte,

Quem há que te não ame?

Tomado com o café em fresca tarde

Derramas tanto ardor pelas entranhas,

Que o já provecto renascer-lhe sente

Da mocidade o fogo!

Cognac! - inspirador de ledos sonhos,

Excitante licor - de amor ardente!

Uma tua garrafa e o Dom Quixote,

É passatempo amável! -

Que poeta que sou com teu auxílio!

Somente um trago teu m'inspira um verso;

O copo cheio o mais sonoro canto;

Todo o frasco - um poema! - 


\section{Minha MÃe \\ Imitação de Cowper}

Quanto eu, pobre de mim! quanto eu quisera Viver feliz com minha mãe também!

C. A. de Sá

Quem foi que o berço me embalou da infância

Entre as doçuras que do empíreo vêm?

E nos beijos de célica fragrância

Velou meu puro sono? Minha mãe!

Se devo ter no peito uma lembrança

É dela que os meus sonhos de criança

Dourou: - é minha mãe! -

Quem foi que ao entoar canções mimosas

Cheia de um terno amor - anjo do bem

Minha fronte infantil - encheu de rosas

De mimosos sorrisos? - Minha mãe!

Se dentro do meu peito macilento

O fogo da saudade me arde lento

É dela: minha mãe.

Qual anjo que as mãos me uniu outrora

$E$ as rezas me ensinou que d'alma vêm?

$\mathrm{E}$ a imagem me mostrou que o mundo adora,

E ensinou a adorá-la? - Minha mãe!

Não devemos nós crer num puro riso

Desse anjo gentil do paraíso

Que chama-se uma mãe?

Por ela rezarei eternamente

Que ela reza por mim no céu também;

Nas santas rezas do meu peito ardente

Repetirei um nome: - minha mãe!

Se devem louros ter meus cantos d'alma

Oh! do porvir eu trocaria a palma

Para ter minha mãe! 
NÃo?

Vi-te: em teu rosto voluptuoso e belo

O anjo formoso dos amores vi!

Amor ardente num olhar, num elo

Destes teus olhos divinais senti!

Vi-te: e prendeu o teu esbelto talhe

O mimo, a graça do teu corpo em flor.

E esses teus lábios como a flor de um baile

Que às auras murcham de festivo amor.

Vi-te: e eras minha ao meu olhar magnético

$\mathrm{E}$ te prendias a fugir de mim!

Fronte de lírios de um candor angélico

Em um perfume me darás um - sim!

Um sim de envolta àquele olhar ardente

Luz de teus olhos, divinal fulgor.

Um sim de envolta àquele rir demente

Reflexo d'alma a delirar de amor!

Um sim! E ao som do teu falar suave

Da minha voz extinguirei o som

Onde gorjeia uma garganta de ave;

Que vale ao homem da palavra o dom?

Íntima frase que só nasce d'alma

Terei nos olhos pra dizer-t’o então

E em troca dela pra colher a palma

Do teu amor, anjo terrestre... não?

25 de abril (1857)

J. M. M. A. 


\section{RESIGNAÇÃO}

Adeus! é o meu suspiro derradeiro!

É a última ilusão que me embebia!

Apagou-se-me o sol das esperanças

E veio a noite sepulcral, sombria...

Adeus... perdoa a um doudo apaixonado

Uma hora de ilusão e de delírio:

Era fatalidade. Após um sonho

Veio a c'roa da dor e do martírio!

Se ao hálito fatal da desventura

Emurcheceu a flor dos meus afetos,

Se não pousaste em minha fronte ardente

Amorosa uma vez teus olhos pretos;

Não te crimino, não; teu culto é livre,

Viver nas ilusões é minha sina:

Não fui fadado pra banhar meus lábios

Nos raios dessa fronte peregrina!

30 de julho 1857

J. M. M. d'Assis

\section{Amanhẽ}

Amanhã quando a lâmpada da vida

$\mathrm{Na}$ minha fronte se apagar, tremendo, Ao sopro do tufão,

Oh! derrama uma lágrima sincera

Sobre o meu peito macilento e triste,

E reza uma oração!

Será uma saudade verdadeira,

Uma flor que me arome a sepultura, 
Um raio sobre o gelo...

Ouvirei a canção das tuas dores,

E levarei saudades bem sombrias

Deste meu pesadelo.

Lembrarei além-túmulo essas noites

Misteriosas, festivais e belas

Da estação dos amores!...

Noites formosas, para amor criadas,

Que coroavam nosso amor tão puro

De ventura e de flores!

Lembrarei nosso amor... E o teu pranto

Ardente como a luz de um sol do estio

Irá banhar-me a campa

$\mathrm{E}$ as lágrimas leais que derramares,

$\mathrm{O}$ astro beijará - que pelas noites

No oceano se estampa!

Um olhar, um olhar desses teus olhos!

Eu o peço, mulher! sobre o meu túmulo

Um olhar de afeição!

Assim o sol - o ardente rei do espaço

Deixa um raio cair nas folhas secas

Que matizam o chão!

Um olhar, uma lágrima, uma prece,

É quanto basta em única lembrança.

Teresa, ao teu cantor.

Chora, reza, e contempla-me o sepulcro

E na outra vida de um viver mais puro

Terás o mesmo amor.

Machado d'Assis 


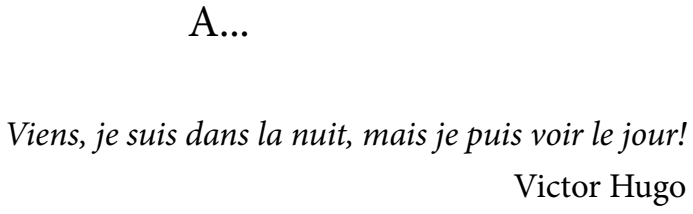

Oh! se eu pudesse respirar num beijo

O teu hálito ardente e vaporoso,

E na febre do amor e do delírio

Sobre o teu seio estremecer de gozo!

Oh! se eu pudesse nessa fronte bela

A coroa depor dos meus amores,

E embevecer-me como em sonho aéreo

De teus olhos nos mágicos fulgores.

Ai! respirara então inda uma vida,

Ó pálida visão!

Nessa flor que os sentidos embriaga

E aroma o coração!

Vem; - dá-me o teu amor; careço dele

Como do sol a flor,

Reanima a cinza de meu peito morto,

Ai! dá-me o teu amor!

Novembro de 1857

Machado d'Assis

\section{Deus em TI}

É quando eu sinto embriagar-me o peito

Um místico vapor,

E à luz fecunda desses olhos belos

Da minh'alma ter vida e alento - a flor;

É quando as tranças dessa fronte loura

Prendem o meu olhar,

E sinto o coração tremer ardente, 
Como uma flor aos zéfiros do mar;

É ao ouvir-te as místicas idéias

Tão cheias de paixão,

Nessa eloqüência lânguida e profunda

Que fala ao coração;

É ao sentir as tuas asas brancas,

Ó meu anjo d'amor,

Que eu reconheço a mão do rei da terra

E creio no Senhor! -

Dezembro de 1857

Machado d'Assis

\section{O SofÁ}

Oh! Como é suave os olhos

Sentir de gozo cerrar,

Sobre um sofá reclinado

Lindos sonhos a sonhar,

Sentindo de uns lábios d'anjo

Um medroso murmurar!

Um sofá! Mais belo símbolo

Da preguiça outro não há...

$\mathrm{Ai}$, que belas entrevistas

Não se dão sobre um sofá,

E que de beijos ardentes

Muita boca aí não dá!

Um sofá! Estas violetas

Murchas, secas como estão

Sobre o seu sofá mimoso,

Cheirosas, vivas então,

Achei um dia perdidas,

Perdidas: por que razão! 
Talvez ardente entrevista

Toda paixão, toda amor

Fizesse ali esquecê-las...

Quem não sabe? sem vigor

Estas flores só recordam

Um passado encantador!

Um sofá! Ameno sítio

Para colher um troféu,

Para cingir duas frontes

De amor num místico véu,

E entre beijos vaporosos,

Da terra fazer um céu!

Um sofá! Mais belo símbolo

Da preguiça outro não há...

$\mathrm{Ai}$, que belas entrevistas

Não se dão sobre um sofá,

E que de beijos ardentes

Muita boca aí não dá!

Dezembro, 1857

Machado d'Assis

\section{Álvares d’Azevedo}

Ao Sr. Dr. M. A. d'Almeida

Vejo em fúnebre cipreste Transformada a ovante palma!

Porto Alegre

Morrer, de vida transbordando ainda,

Como uma flor que ardente calma abrasa!

Águia sublime das canções eternas:

Quem no teu vôo espedaçou-te a asa?

Quem nessa fronte que animava o gênio,

A rosa desfolhou da vida tua? 
Onde o teu vulto gigantesco? Apenas

Resta uma ossada solitária e nua!

E contudo essa vida era abundante!

$\mathrm{E}$ as esperanças e ilusões tão belas!

E no porvir te preparava a pátria

Da glória as palmas e gentis capelas!

Sim, um sol de fecunda inteligência

Sobre essa fronte pálida brilhava,

Que à face deste século de indústria

Tantos raios ardentes derramava!

E pôde a morte destruir-te a vida!

$\mathrm{E}$ dar à tumba a tua fronte ardente!

Pobre moço! saudaste a estrela d'alva,

E o sol não viste a refulgir no Oriente!

Morrer, de vida transbordando ainda,

Como uma flor que ardente calma abrasas!

Águia sublime das canções eternas:

Quem no teu vôo espedaçou-te a asa?

Voltaste à terra só! - Não morrem Byrons,

Nem finda o homem na friez da campa!

Homem, tua alma aos pés de Deus fulgura,

Teu nome, poeta, no porvir se estampa!

Não morreste! estalou a fibra apenas

Que a alma à vida de ilusões prendia!

Acordaste de um negro pesadelo,

E saudaste o sol do eterno dia!

Mas cá fica no altar do pensamento

Teu nome como um ídolo pomposo,

Que a fama com o turíbulo dos tempos

Perfuma de um incenso vaporoso!

E ao ramalhete das brasílias glórias,

Mais uma flor angélica se enlaça, 
Que a brisa ardente do porvir passando

Trêmula beija e a murmurar abraça!

Byron da nossa terra, dorme embora

Envolto no teu fúnebre sudário,

Murmure embora o vento dos sepulcros

Junto do teu sombrio santuário.

Resta-te a c'roa santa de poeta,

E a mirra ardente da oração saudosa,

E pelas noites calmas do silêncio

Os séculos da lua vaporosa!

Ela te chora, e ali com ela a pátria,

Pobre órfã de teus cânticos divinos,

E das brisas na voz misteriosa,

Da saudade da dor sagram-te os hinos!

Dorme junto de Chatterton, de Byron,

Frontes sublimes, pra sonhar criadas,

Almas puras de amor e sentimento,

Harpas santas, por anjos afinadas!

Dorme, na tua fria sepultura

Guarda essa fronte vaporosa, ardente,

$\mathrm{Tu}$, que apenas saudaste a estrela d'alva

E o sol não viste a refulgir no Oriente!

Joaquim Maria Machado d'Assis

\section{VAI-TE}

Por que voltaste? Esquecidos

Meus sonhos, e meus amores

Frios, pálidos morreram

Em meu peito. Aquelas flores

Da grinalda da ventura 
Tão de lágrimas regada,

Nesta fronte apaixonada

Cingida por tua mão,

Secaram, mortas estão.

Pobre pálida grinalda!

Faltou-lhe um orvalho eterno

De teu belo coração.

Foi de curta duração

Teu amor: não compreendeste

Quanto amor esta alma tinha.

Vai, leviana andorinha,

A outro clima, outro céu:

Meu coração? já morreu

Para ti e teus amores,

E não pode amar-te - vai!

O hino das minhas dores

Dir-to-á a brisa, à noite.

Num terno, saudoso - ai -

Vai-te !- e possa a asa do vento

Que pelas selvas murmura

Da grinalda da ventura

Que em mim outrora cingiste,

Inda um perfume levar-te,

Morta assim: como um remorso

Do teu olvido... eu amar-te?

Não, não posso; esquece, parte;

Eu não posso amar-te... vai!

$1^{\circ}$ de janeiro de 1858

Machado d'Assis

\section{Esta NoIte}

Os teus beijos ardentes,

Teus afagos mais veementes,

Guarda, guarda-os, anjo meu;

Esta noite entre mil flores, 
Um sonho todo de amores

Nos dará de amor um céu!

Machado d'Assis

\section{REFLEXO}

Olha: vem sobre os olhos

Tua imagem contemplar,

Como as madonas do céu

Vão refletir-se no mar

Pelas noites de verão

Ao transparente luar!

Olha e crê que a mesma imagem

Com mais ardente expressão

Como as madonas no mar

Pelas noites de verão,

Vão refletir-se bem fundo,

Bem fundo - no coração!

Machado d'Assis

A Morte no CAlvário

Ao meu amigo o Padre Silveira Sarmento

Consummatum est!

I

Ei-lo, vai sobre o alto do calvário

Morrer piedoso e calmo em uma cruz!

Povos! naquele fúnebre sudário

Envolto vai um sol de eterna luz! 
Ali toda descansa a humanidade;

É o seu salvador, o seu Moisés!

Aquela cruz é o sol da liberdade

Ante o qual são iguais povos e reis!

Povos, olhai! - As fachas mortuárias

São-lhe os louros, as palmas, e os troféus!

Povos, olhai! - As púrpuras cesáreas

Valem acaso em face do Homem-Deus?

Vede! mana-lhe o sangue das feridas

Como o preço da nossa redenção.

Ide banhar os braços parricidas

Nas águas desse fúnebre Jordão!

Ei-lo, vai sobre o alto do calvário

Morrer piedoso e calmo em uma cruz!

Povos! naquele fúnebre sudário

Envolto vai um sol de eterna luz!

II

Era o dia tremendo do holocausto...

Deviam triunfar os fariseus...

A cidade acordou toda no fausto,

E à face das nações matava um Deus!

Palpitante, em frenético delírio

A turba lá passou: vai imolar!

Vai sagrar uma palma de martírio,

E é a fronte do Gólgota o altar!

Em derredor a humanidade atenta

Aguarda o sacrifício do Homem-Deus!

Era o íris no meio da tormenta

O martírio do filho dos Hebreus!

Eis o monte, o altar do sacrifício

Onde vai operar-se a redenção. 
Sobe a turba entoando um epinício

E caminha com ele o novo Adão!

E vai como ia outrora às sinagogas

As leis pregar do Sião e do Tabor!

É que no seu sudário as alvas togas

Vão cortar os tribunos do Senhor!

Planta-se a cruz. O Cristo está pendente;

Cingem-lhe a fronte espinhos bem mortais;

E cospe-lhe na face a turba ardente,

E ressoam aplausos triunfais!

Ressoam como em Roma a populaça

Aplaudindo o esforçado gladiador!

É que são no delírio a mesma raça,

A mesma geração tão sem pudor!

Ressoam como um cântico maldito

Pelas trevas do século a vibrar!

Mas as douradas leis de um novo rito

Vão ali no calvário começar!

Sim, é a hora. A humanidade espera

Entre as trevas da morte e a eterna luz.

Não é a redenção uma quimera,

Ei-la simbolizada nessa cruz!

É a hora. Esgotou-se a amarga taça;

Tudo está consumado, ele morreu.

E aos cânticos da ardente populaça

Em luto a natureza se envolveu!

Povos! realizou-se a liberdade,

E toda consumou-se a redenção!

Curvai-vos ante o sol da cristandade

E as plantas osculai do novo Adão!

Ide, ao som das sagradas melodias,

Orar junto do Cristo como irmãos, 
Que os espinhos da fronte do Messias

São as rosas da fronte dos cristãos!

Semana Santa de 1858

Machado de Assis

\section{Ao Carnaval de 1860}

Morreste, seriedade!

Momo, o deus das zombarias,

Usurpou-te, por três dias,

Teu esplêndido bastão!

De um exílio temporário

Toma a longa e nova rota;

Agora reina a chacota

E o carnaval folgazão!

Diante das aras da rubra folia,

Cabeça a mais séria não vale um real;

Doudice, festança e alegria,

Tudo isto é fortuna que traz - CARNAVAL.

Homem sério e bem formado,

Neste dia é contrabando;

Respeitado e venerando

É cousa que não se diz;

A razão abrindo os lábios,

Onde tem berço o juízo,

Vestiu um chapéu de guizo,

E pôs um falso nariz!

Nem pai de família, nem velho empregado,

Doutor, diplomata, caixeiro ou patrão,

Ninguém, ó loucura, no dia aprazado,

Não pode negar-te seu grande quinhão.

Tudo a loucura nivela,

Nem há luta de inimigos: 
Esqueçam-se ódios antigos

De algum ferrenho eleitor;

Há tréguas por três dias

No campo dos candidatos,

Que o feijão ferve nos pratos

E os guizos falem melhor.

Esqueça-se tudo, são todos convivas,

Os ódios se apaguem no abraço comum:

Que doce batalha! Que lutas festivas!

Daqui deste campo não foge nem um!

Todas as belas amáveis

Podem ter parte na festa:

Sacerdotisas e Vesta,

Acendei os corações!

Pra sustentar a empresa

Não tendes armas faceiras?

É não tirar as pulseiras

E conservar os balões.

Daí das janelas olhando curvadas.

Sem dar um só passo na luta venceis:

Ao fogo, que corre das vossas sacadas

Aquiles se curvam e algemam-se reis.

Os reis, conquanto pintados,

Sempre são reis por três dias;

E sabem as galhardias

Das vossas armas leais.

Nós somos a Roma inerte

Com a invasão peregrina,

Que os Hunos de crinolina

São mais que os outros fatais.

M. A. 


\section{Prosa}




\section{IDÉIAS VAGAS}

A POESIA. A poesia, como tudo que é divino, não pode ser definida por uma palavra, nem por mil. É a encarnação do que o homem tem de mais divino no pensamento, do que a natureza divina tem de mais magnífico nas imagens, de mais melodioso nos sons.

Lamartine

Sabeis o que é a poesia?

É difícil explicá-la: é um sentir sem definição; é uma palavra que o anjo das harmonias segreda no mais íntimo d’alma, no mais fundo do coração, no mais recôndito do pensamento. A alma, e coração, e o pensamento compreendem essa palavra, compreendem a linguagem em que lhe foi revelada - mas não a podem dizer nem exprimir.

O que vos inspira o oceano plácido e sereno - em uma noite de verão quando a lua brilha em um céu límpido e azul - e quando uma viração suave respira com voluptuosidade e frescura?

O que vos inspira aquela melodia santa e pura do órgão no recinto do templo, quando a Igreja celebra alguma das passagens da história da nossa religião? O que vos inspira aquele quadro sublime quando no cume de uma montanha devassais com olhar e com espírito - o vale dourado pelos últimos reflexos do sol e o mar afogueado recebendo em seu seio o rei da luz? O que vos inspira tudo isto?

O que vos inspira toda a natureza sorrindo com seus trajes embelecidos e decorados pela mão do Sábio - o Supremo Pintor?

Um sentimento doce - um êxtase d'alma e dos sentidos que faz adormecer o espírito e o pensamento; um sentimento que só a alma o compreende, mas que e indefinível.

É isto a Poesia!

É uma bela filha da imaginação do Criador; uma rosa criada por ele, e por ele depositada na fronte de Homero, o chefe divino e supremo dessa nação que se tem estendido por todo o universo, e que dominará todas as demais nações. - É magnífico o vaso para o qual Deus transplantou essa rosa, - cujo perfume foi a Ilíada e a Odisséia.

Floresceu pois na Grécia; ali viu ela os seus incansáveis cultivadores ocupados no seu engrandecimento, sacrificando-lhe o sossego, os interesses e o repouso para alcançarem as bênçãos de uma posteridade agradecida.

A emulação favorecia então o engrandecimento da poesia. O poeta que nas suas lucubrações sacrificava as horas de descanso, só tinha em vista o brilhante prêmio - a coroa de vencedor com que nos jogos olímpicos tinha de adornar a sua fronte. Era no meio de aplausos que ele cingia e abençoava as horas que havia consagrado às suas vigílias e meditações.

Não há dúvida, a poesia reinava então; umas vezes guerreira e marcial como o clangor das trombetas nas batalhas; outras vezes terna e cheia de amor como os sorrisos de Vênus, a filha do mar - e o protótipo das graças e da formosura.

Esses aplausos fervorosos, contudo, e esse acolhimento das obras do poeta - não os pode livrar dessa fatalidade horrível, cujo selo lhe está marcado na fronte! - É uma sentença que decretalhe um fim desgraçado e miserável! - Inevitável destino! 
A Grécia deixou mendigar o cantor das suas glórias - o selo de todos estes reis, que adornam o céu límpido, o céu da poesia, o criador da mais bela parte da sua história, e daí todas as mais nações seguiram este exemplo de vergonha e d'ignomínia!

A raça lusitana coberta de glórias pelas suas imortais conquistas na África e na Ásia só teve para o divino cantor dos Lusíadas um pobre leito de miséria. Pátria homicida que até negou o beijo materno extremo ao seu mais belo filho!

Debalde se cansa o gênio em varrer de todos os lábios esse sorriso de indiferença que faz gelar n’alma as mais belas concebidas esperanças: - o mundo não os escuta. Bocage no seu poetar de ironias não pôde reformar aquela sociedade de homens indiferentes esmagadores de talento - em que vivia!

É horrível - mas é verdade! É a realidade descarnada com toda a sua hediondez, com o seu aspecto pavoroso e negro: - é o fim do poeta!

Ele tem uma missão a cumprir neste mundo - uma missão santa e nobre, porque é dada por Deus! - É um pregador incansável - um tradutor fiel das idéias do Onipotente.

O mundo, porém, não compreende aquela alma tão grande como o universo - tão divina como a mais bela porção do espírito de Deus.

Tarde o mundo conhece o que perde no poeta que morre. O sangue já havia desaparecido da face do cadafalso, quando a França conheceu que havia perdido dous gênios em Foucher ${ }^{3}$ e A. Chénier. - Sacrificaram às conveniências políticas dous poetas - dous mártires que abandonando sobre a terra a argila mundana remontaram-se puros e radiantes ao seio de Deus!

Eis pois o que são perante o mundo aqueles para quem a poesia é incentivo da sua linguagem ardente e animada. O leito de Gilbert, - o cadafalso de Foucher, e a masmorra de T. Tasso, são exemplos para aqueles cujas idéias divinas e ardentes se vertem em candenciosos hinos de melodiosas harpas.

Aqui terminam as minhas idéias sobre a poesia, e sobre os poetas. - Perdoai, leitores, a minha fraca linguagem; é de um jovem que estréia nas letras, e que pede proteção e benevolência. Ainda existem alguns Mecenas piedosos: animai o escritor.

Continuarei as minhas - idéias vagas.

As.

\section{IDÉIAS VAGAS \\ A COMÉdia Moderna}

O teatro, assim como a imprensa, é uma página brilhante pela qual se conhece o estudo e o grau de civilização de um povo. - É isto uma verdade teórica - conhecida por todos - e que felizmente está

3. Jean-Michel Massa afirma que embora o texto registre "Foucher", o nome correto é "Roucher". Cf. Dispersos de Machado de Assis, p. 487. 
ao salvo de quaisquer contestações, porque é inegável que a França, a sede das civilizações modernas, o foco luminoso da literatura e das ciências, mostra nas suas composições teatrais o esplêndido e alto grau de sua civilização - e progresso intelectual.

Assim é: e graças a essa demonstração da vencedora de Malakoff - nós vemos que a locomotiva não tem esmagado na sua celeridade - as obras da imaginação - e que a matéria está ainda longe de eclipsar o espírito.

Mas, todavia, o progresso material absorve as atenções, e o espírito inventivo trata de pensar, estudar, e corrigir o mundo na sua construção material - dando-lhe um aspecto novo! - Viva Deus! - Inglaterra! Inglaterra! Rainha da Indústria! - centro de toda a revolução material! - Eis-te aí - desmentindo a distância com teus dourados pensamentos de civilização! Eis-te aí excêntrica e vaidosa, falando em progressos, mas ocultando debaixo dessas idéias progressistas os projetos de uma desmedida ambição! Culpado!... Evitai que no meio de teus banquetes com o último rei de Babilônia alguma mão invencível trace a tua sentença de morte!

No meio, pois, destes desvarios, de progressos e civilização, é o teatro olhado como o verdadeiro lugar de - distração e ensino; - o verdadeiro meio de civilizar a sociedade e os povos.

Ao teatro! Ao teatro ver as composições dramáticas da época, as produções de Eméry ${ }^{4}$ e Bourgeois! - Ao teatro ver a sociedade por todas as faces: frívola, filosófica, casquilha, avara, interesseira, exaltada, cheia de flores e espinhos, dores e prazeres, de sorrisos e lágrimas! - Ao teatro ver o vício em contato com a virtude; o amor no coração da mulher perdida, como a pérola no lodo do mar; o talento separado da ignorância apenas por um copo de champanhe! - Ao teatro ver as cenas espirituosas da comédia moderna envolvendo uma lição de moral em cada dito gracioso; ver a interessante coquette que jura amor em uma valsa e perjura em uma quadrilha; ver o literato parasita que não se peja de subir as escadas de mármore do homem abastado, mas corrupto, curvar-se cheio de lisonja para ter a honra de sentar-se a seu lado e beber à sua saúde!

Ao teatro! Ao teatro!

Oh! que é sublime! O gosto dramático adotado pelo século é assaz belo, e mostra a emblemidade das idéias progressivas dos talentos da época!

Entre nós, porém, (desculpe-me, se há erro em dizê-lo) este modernismo é pouco aplaudido. Não sei se é a nova era das edificações líricas e celebridades cantantes, o motivo desta indiferença para com os progressos do teatro dramático; em todo caso, porém, para mim, é evidente que o motivo dessa indiferença é em grande parte a perniciosa existência entre nós de alguns frenéticos apreciadores da farsa antiga e sem gosto, das clássicas cabriolas e da atroadora pancadaria empregada quando o espírito falece em fastiosos e insípidos diálogos.

Destes apreciadores de que acabo de falar eu conheço alguns que me têm dito muitas vezes: “- Vale mais apreciar os admiráveis saltos do Recrutamento n’Aldeia, do que uma cena do Amigo Grandet" (!).

4. Segundo Massa, há três diferentes formas de se grafar corretamente o nome desse dramaturgo: Ennery, d'Ennery ou Dennery. Cf. Dispersos de Machado de Assis, p. 487. 
É isto verdade puríssima; mas como nesta terra nem todas as verdades se dizem, já eu estou arrependido: enfim, já está escrito, e agora o que está, está.

Como disse, pois, as tendências pouco favoráveis ao desenvolvimento da comédia moderna, nascem sem dúvida em grande parte desta classe do nosso povo. O leitor reflexionando sobre o que acabo de dizer concordará com as minhas idéias.

Vou acabar. - Cumpre mesmo não tomar muito espaço em uma folha onde se publica um poema de Lord Byron (entre parênteses; dou os emboras ao Sr. Paula Brito por uma publicação tão útil, quão agradável).

Nunca escrevi tão vagamente as minhas idéias como hoje: é porque estou com bastante pressa.

Humilde servo.

As.

\section{IDÉIAS VAGAS}

\section{Os CONTEMPorÂneos}

\section{Monte Alverne}

A humanidade flutua entre dous pontos totalmente opostos: - o bem e o mal -. Os sectários do mal são os inimigos declarados da virtude; são os viciosos, esses que têm uma crença por necessidade e não por convicção, para quem o nome de Deus é uma expressão vulgar e à qual se não deve respeito algum. Os sectários do bem são os adversários do vício: são os virtuosos, em cujo coração convicto se aninha a fé e a crença com todo o ardor e pureza, com todo o respeito e entusiasmo.

Ora, o bem e o mal são dous caminhos diversos no aspecto e no termo; o primeiro é cheio de abrolhos; o segundo, de flores: no fim do primeiro há flores; no do segundo, espinhos. As almas fracas, as naturezas superficiais, deixam-se levar pelas aparências, e, trilhando a senda do mal, aspiram o perfume venenoso dessas flores que vegetam debaixo de seus pés; os espíritos profundos e filosóficos, observadores dos dogmas sagrados, lançam-se ao bem e enxugam nas flores do termo do seu caminho o sangue vertido de seus pés pelo contato dos espinhos.

Se não tivera de escrever as minhas idéias tão rapidamente, eu evocaria as veneráveis sombras daqueles mártires da Idade Média, mártires pela fé, e pelo dogma, cuja história tão sanguinolenta foi cantada pelo imortal Chateaubriand. Evocaria, porque vou falar de um homem tão crente, tão resignado, tão virtuoso, como os ilustres batalhadores cruzados que nas épocas calamitosas da Cristandade deram seu sangue a prol da religião. Mas essa evocação poder-me-ia levar insensivelmente a reflexões por demais longas, e é força que eu seja breve, muito breve. 
E, pois, duas palavras podem servir para uma invocação:

- Religião, inspirai-me!

A eloqüência, da tribuna profana, está muito aquém da do púlpito. Cícero, o maior eloqüente da Antigüidade, é menos que Bossuet, porque no mundo profano os espíritos apaixonados defendem os seus interesses e as suas opiniões; no mundo religioso, há só um ponto fixo onde estão todas as vistas, e à roda do qual se volvem todas as idéias; esse ponto é grande e sublime, e se se falar dele com a mais simples linguagem, isso mesmo será eloqüente.

Mont'Alverne é um nome de uma extensão infinita, que desperta em nossos corações as sensações mais profundas, o entusiasmo mais férvido, porque - Mont'Alverne - quer dizer - uma glória do Brasil, um primor do púlpito, um Bossuet nascido nas plagas brasileiras e inspirado na solidão do claustro!

Vede-o no fundo de uma cela sombria e humilde, pálido e abatido pela idade e pelos sofrimentos; vede-o ali com a mais severa humildade. É um inspirado de Deus. Mas infeliz! Em vão seus olhos procuram ver a luz do sol; estão fechados para sempre! Só a luz do gênio, uma lâmpada erguida num santuário, ilumina aquele espírito tão sublime, tão admirável como esse círculo de fogo, que brilha constante no universo!

Olhe-o! Contemplai aquela nobre fronte empalidecida pelos anos, e pela disciplina, iluminada pelo gênio e pela fé; deixai-vos impressionar por todas as idéias que essa contemplação vos lançar na imaginação, e reconhecei nele o homem virtuoso, eloqüente, admirável, a expressão mais sublime da grandeza de Deus!

Falai-lhe, procurais ouvir-lhe aquela voz eloqüente e poderosa, ouvi-lhe aquelas frases, pesai bem a sublimidade de sua linguagem; e se quando penetrastes naquele retiro, levastes o ceticismo no coração, trareis, no sair dele a crença e a fé, porque a eloqüência daquele homem sagrado, convence ao cético da existência de Deus, e planta a fé na alma do ateu!

Um apóstolo de Cristo, pregando e convencendo as turbas da sua existência, não lega a Deus só a sua alma, ele lhe dá também mil outras, que com a sua palavra faz entoar no grêmio da fé e do Catolicismo! E pois: quantos corações, alentados por uma crença duvidosa, ou totalmente descrentes dos dogmas sagrados, não se terão convertido ao ouvir a sublime linguagem daquele Apóstolo sagrado?

Mont'Alverne, o homem eloqüente e virtuoso, cuja vida se tem passado na austeridade e solidão do Claustro, é uma prova da solidez dos nossos princípios religiosos! Se o seu horizonte material acaba na parede sombria de uma cela humilde, os seus limites intelectuais chegam até Deus, isto é, perdem-se no infinito!

As. 


\section{A Literatura durante a RestauraÇão}

(Por Lamartine - Tradução de M. de Assis)

I

Esta época foi o acordar do espírito humano.

O décimo oitavo século foi interrompido em suas idéias, suas obras e suas artes, por uma catástrofe que dispersou os seus filósofos, poetas, oradores e escritores. A emigração, o terror e o cadafalso decimaram a inteligência. Condorcet e Chamfort entregaram-se à morte; André Chénier e Roucher caíram debaixo do cutelo; Mirabeau estava morto de fadiga na revolução, e talvez de angústia, diante das perspectivas que não podiam escapar ao seu gênio; Verginaud ${ }^{5}$ desapareceu na tempestade, feliz por ter escapado ao espetáculo do crime pelo martírio da eloqüência à que aspirava; Delille fugiu da pátria e cantou aos exilados na Polônia e em Inglaterra; o abade Raynal envelheceu no arrependimento e no desengano de suas esperanças; Parny transformou (avait travesti) seus amores em cinismo e vendeu-se aos publicanos. A filosofia e a literatura em França, no fim de reinado de Napoleão, foram condenadas ao silêncio ou disciplinadas e alinhadas como batalhões assalariados debaixo do sabre. A natureza estava exaurida de homens no começo do século para preparar e completar a revolução. Completa a revolução, - a idéia que a criou parecia ter medo de si mesma, vendo que depois do seu parto teria o enfraquecimento.

Bonaparte, que aspirava à tirania, que odiava a idéia, porque é a liberdade d'alma - aproveitou este esgotamento e este cansaço de espírito humano para assomar ou enervar a literatura: favoreceu apenas as ciências matemáticas, porque os algarismos medem, contam, e não pensam. Ele só honrava as faculdades humanas, das quais podia fazer dóceis instrumentos. Os geômetras eram os seus homens; os escritores faziam-no tremer: era o século do compasso. Ele só tolerava esta literatura frívola que distrai o povo e que incensa a tirania. Teria feito calar a voz cujo acento varonil tivesse tocado uma das cordas graves do coração humano. Consentia as trovas que ensurdecem o ouvido, mas a poesia que exalta a alma, não. O jovem Nodier escreveu nas montanhas do Jura - uma ode que respirava muito alto para o servilismo do tempo; o poeta foi obrigado a proscrever-se à vista da proscrição que o espiava.

\section{II}

Era necessário que a tirania de Napoleão fosse bem severa para que a volta do Antigo Regime parecesse restituir a liberdade e a respiração à alma. - Entretanto assim aconteceu. - Apenas o Império foi derribado, começou-se a pensar, escrever e cantar em França. Os Bourbons, contemporâneos da nossa literatura, arrogam-se a glória de terem-na levado consigo. $\mathrm{O}$ regime constitucional restituía a palavra a duas tribunas. Apesar de algumas leis preventivas, ou repressivas, a liberdade da imprensa restituía a respiração às letras. Tudo o que tinha emudecido tomou de novo a voz; os espíritos humilhados pela compressão, a sociedade ávida de idéias, a mocidade impaciente de glória intelectual, vingava-se do longo silêncio por um brotar súbito e quase contínuo de filosofia, história,

5. A forma adequada é Vergniaud. Cf. Jean-Michel Massa, op. cit., p. 489. 
poesia, polêmica, memórias, dramas, obras de arte e imaginação. O século de Francisco I teve mais originalidade; o século de Luís XIV teve mais glória; nem um, nem outro tiveram mais entusiasmo e movimento que estes primeiros anos da Restauração. O servilismo tinha acumulado tudo nas almas durante vinte anos. Elas estavam cheias, transbordavam. A História lhes deve as suas páginas. Estas páginas não são somente os anais das guerras ou das cortes, são além de tudo os anais ${ }^{6}$ do espírito humano.

III

Grandes espíritos tinham amadurecido durante estes anos de opressão; eles reapareceram em sua liberdade e em seu brilho. Mme. de Staël e M. de Chateaubriand partilhavam desde vinte anos a admiração da Europa e a perseguição de Napoleão.

Mme. de Staël, filha de M. Necker, gênio precoce, educada no salão de seu pai com a leitura e a conversação dos oradores, filósofos e poetas do décimo oitavo século tinha respirado a revolução em seu berço. Filha da Helvécia, transplantada para as cortes, a sua alma e o seu estilo participavam desta dupla origem. Ela era republicana na imaginação e aristocrática nos costumes. Havia nela Rousseau e Mirabeau: pensativa como um, oratória como o outro. O seu verdadeiro partido em política era o partido girondino. Mais vasta de talento, mais generosa d'alma que Mme. Roland, era um grande homem com as paixões de uma mulher. Mas essas paixões ternas e fortes davam ao seu talento as qualidades de sua alma, o acento, fogo e heroísmo do sentimento. Napoleão julgava-a mais perigosa que Lafayette à sua tirania. Exilou-a para longe de Paris. Este ostracismo fez de sua casa, às margens do lago Genebra, os derradeiros lares ela liberdade. Os escritos de Mme. de Staël, quer poéticos, quer políticos ainda que prescritos ou mutilados pela polícia, deixavam sempre transpirar em França e na Europa durante o reinado do Império as chamas do coração, os entusiasmos do espírito, as aspirações da liberdade, e o santo ódio do embrutecimento e do servilismo. Esta mulher foi a derradeira Romana no reinado deste César que não ousava feri-la, e que pôde envilecê-la. Restavam-lhe ainda amigos fiéis e generosos, tanto homens, como mulheres: Mathieu de Montmorency, Mme. Recamier, os filósofos alemães, os poetas da Itália, os homens de Estado liberais de Inglaterra.

Durante os últimos anos do reinado, em que a queda acelerada tornava Napoleão mais implacável, Mme. de Staël tinha fugido até ao fundo do Norte. Ela reprova a insurreição dos corações e dos povos contra o opressor do espírito humano 7 . À sua queda reapareceu ela em Paris, triunfante sobre as minas do seu inimigo; o mundo armado vingava-o sem pensá-lo. Ela queria que esta vitória das nações contra a conquista fosse também a história da liberdade contra o despotismo. Amadurecida pelos anos e pela experiência das cousas humanas, ela tinha perdido a severidade dessas idéias republicanas que fanatizavam a sua mocidade em 1791 e 1792. Ela tinha recordações benévolas dos Bourbons. Esperava muito de uma restauração experimentada como ela pelo cadafalso e pelo exílio, e que reconciliaria em torno do trono as liberdades representativas com as tradições do sentimento

6. No texto publicado na Marmota aparece aqui a palavra "anos", no entanto, para se estabelecer o paralelismo da frase, é necessário trocá-la para "anais".

7. Segundo Massa, esta frase do texto original de Lamartine registra o contrário do que foi traduzido. Cf. Jean-Michel Massa, op. cit., p. 489. 
nacional. O seu salão, em Paris, era uma das forças da Restauração; sua eloqüência convertia os velhos republicanos, os jovens liberais, as almas indecisas, a um regime constitucional imitado da Inglaterra, que restituía a independência às opiniões, a tribuna aos oradores, o governo à inteligência. Luís XVIII, pela elevação do seu espírito, por seus gostos literários, pela graça das suas admirações para ela, consolava-a dos desdéns e das brutalidades de Napoleão; ele tratava Mme. de Staël como aliada à sua coroa, porque ela representava o espírito europeu.

IV

Mme. de Staël era feliz então pelo coração tanto quanto gloriosa pelo gênio. Tinha dous filhos: um filho que não revelava o fulgor de sua mãe, mas que prometia todas as qualidades sólidas e modestas do patriota e do homem de bem; uma filha casada depois com o duque de Broglie, que assemelhava-se à mais bela, e à mais grave idéia de sua mãe, encarnada sob uma forma angélica para elevar o olhar ao céu e figurar a santidade da beleza. Apenas no meio da vida, moça desta mocidade renascente que renova a imaginação, esta seiva de amor, Mme. de Staël, acabava de esposar o último ídolo do seu sentimento; era amada e amava.

As suas Considerações sobre a Revolução, que viu tão de perto, uma narração pessoal e apaixonada dos seus dez anos de exílio, enfim, um livro sobre o gênio da Alemanha no qual tinha ela derramado e como filtrado gota a gota todas as fontes de sua alma, da sua imaginação e da sua religião, acabavam de aparecer ao mesmo tempo ${ }^{8}$ e faziam o entretenimento da Europa. O seu estilo no livro da Alemanha sobretudo, sem perder nada da sua mocidade e de seu esplendor, parecia estar iluminado de fulgores mais altos e mais eternos, aproximando-se da noite da vida, e dos altares misteriosos do pensamento.

Este estilo já não pintava, já não contava, adorava apenas; respirava-se o incenso de uma alma em suas páginas; era Corina feito sacerdotisa e entrevendo dos extremos da vida o Deus ignoto no fundo dos horizontes da humanidade.

Foi então que ela morreu em Paris deixando um deslumbramento imenso no coração de seu século. É o João Jacques Rousseau das mulheres, porém mais terna, mais sensata, mais capaz de grandes ações do que ele. Gênio de dous sexos! um para pensar, outro para amar! A mulher mais apaixonada e o escritor mais viril em um só ente! Nome que viverá tanto como a literatura e a história de seu país.

\section{$\mathrm{V}$}

Mr. de Chateaubriand foi então o único homem que pôde contrabalançar a nomeada desta mulher. Inimigo como ela de Bonaparte, porque há guerra natural entre o gênio da idéia e o gênio da opressão, a queda do soldado que deste ofuscava tudo, deixava aparecer estes dous grandes escritores.

Mr. de Chateubriand, fidalgo bretão nascido sobre as praias do oceano, embalado ao

8. Massa indica que a versão para a língua portuguesa omitiu os países: "na França e na Inglaterra". Cf. Jean-Michel Massa, op. cit., p. 490. 
murmúrio dos ventos e das ondas da sua pátria, lançado logo pelo acaso do nascimento, mais que por suas opiniões incertas, nos campos errantes da emigração, depois nas florestas da América, depois nos nevoeiros de Londres, era o Ossian francês; ele tinha na imaginação as vagas, as cores, a imensidade, os gritos, os lamentos, o infinito. Seu nome era uma harpa eólia entoando sons que arrebatam o ouvido, que agitam o coração, e que o espírito não pode definir, o poeta mais de instintos que de pensamentos, a recordação, e o pressentimento de um não sei quê, o murmúrio misterioso dos elementos. Este homem ressoou em todas as almas e conquistou um imenso império, não sobre a razão, mas sobre a imaginação dos tempos.

Como todos os grandes talentos ele nasceu de si. Só, ocioso, miserável em Londres durante os últimos anos da República, escreveu um livro cético como a sua idéia, e como as ruínas que o desmoronamento da Igreja e do trono espalhou pelo mundo.

Disseram-lhe: Não é isso; o mundo não quer mais duvidar, porque tem precisão de esperar; restitui-lhe a fé. Jovem, melancólico inclinado às crenças, indiferente à natureza das emoções, contanto que essas emoções se transformassem em aplausos e em glória depois de o terem agitado, ele queimou o seu livro, e escreveu outro: desta vez era o Gênio do Cristianismo.

A filosofia tinha vencido; a revolução tinha destruído e imolado em seu nome; os filósofos eram acusados de todas as calamidades do tempo, tornaram-se impopulares como os destruidores são amaldiçoados pelos fiéis, cujo templo arruinaram. M. de Chateubriand empreendeu a obra de reconstruí-lo na imaginação; queria ser o Esdras da Igreja destruída e dos adoradores dispersados.

VII

Um filósofo piedoso tinha de fazer uma obra bela e santa sobre um plano semelhante. A filosofia religiosa e luminosa avançava de século em século; penetrando raio a raio nas sombras dos templos fez empalidecer as superstições, evaporar os ídolos, e deu mais luz, mais razão e por conseqüência mais divindade aos altares. Uma filosofia ímpia, cínica, materialista, tinha-se unido nos últimos tempos à construção da Igreja e viciou-a e perverteu-a, envolvendo-se nela. Remontar às origens do cristianismo, purificar os corações, mostrar aos homens do nosso tempo quanta santidade, virtude e eficácia lançou Deus nas doutrinas e nas instituições do cristianismo; quantas superstições, idolatria, vício e corrupção aí lançaram a ignorância, a força, a fraude e o barbarismo; dar a Deus o que era de Deus, aos homens o que era dos homens; ao passado o que dever morrer com ele, ao futuro o que dever durar e vivificar a alma humana, fazendo-lhe respirar uma idéia mais pura da Divindade ${ }^{9}$, e impregnando nela os cultos, a legislação, a política, todas as obras sociais da mais perfeita santidade: era isto a obra de uma grande razão, de uma grande imaginação, e de uma grande piedade, agitando com uma mão respeitosa, mas livre, as ruínas do santuário antigo para reerguer o santuário novo.

9. Segundo Massa, todo o trecho a partir de "quantas superstições, idolatria" até "idéia mais pura da Divindade" não está no original de Lamartine. Trata-se de uma crítica do tradutor, Machado de Assis, que defendia o princípio de separação dos domínios de Estado e Igreja. Cf. Jean-Michel Massa, op. cit., p. 490. 
M. de Chateaubriand era dotado de uma razão bastante alta para empreendê-lo e de um gênio assaz grande para completá-lo.

$\mathrm{O}$ cristianismo teria tido o seu Montesquieu, excetuando a poesia ${ }^{10}$.

\section{VIII}

Em lugar desta obra, M. de Chateaubriand fez em seu livro, como Ovídio os Fastos da Religião. Exumou, não o gênio, mas a mitologia e o cerimonial do cristianismo. Cantou indistintamente e sem crítica, seus dogmas e suas superstições, sua fé, e suas credulidades, suas virtudes e seus vícios; fez o poema de todas as suas antigüidades populares, todas as suas instituições decaídas: desde a dominação política das consciências pelo alfange, até as riquezas temporais da Igreja; desde as aberrações de ascetismo monacal até as suas ignorâncias beatificadas e até as fraudes piedosas dos prodígios populares inventadas pelo zelo e perpetradas pela rotina do clero rural para seduzir a imaginação, em vez de santificar o espírito dos povos: M. de Chateaubriand divinizou tudo. O seu livro foi o relicário das credulidades humanas.

\section{IX}

Teve um imenso sucesso. Eram duplas as razões disso, no escritor por seu gênio, na opinião por sua tendência. A revolução tinha agitado e desorientado o espírito humano. Os terremotos produzem um delírio; o povo vendo desabar ao mesmo tempo o trono, a sociedade e os altares, pensou haver chegado à consumação dos tempos. O ferro e o fogo devastaram os templos; a impiedade perseguiu a fé, o cutelo feriu os padres, a consciência e a oração foram obrigadas a ocultarem-se como crimes; o Deus doméstico tornou-se um segredo entre o pai, a mãe e os filhos; a perseguição enterneceu o povo pelo sacerdócio, o sangue santificou os mártires, as ruínas dos templos juncavam o chão e pareciam acusar a terra de ateísmo. Ainda mais, o mundo estava triste como depois das grandes comoções; uma melancolia inquieta prendia as imaginações; buscava o seu oráculo para dizer ao gênero humano o seu futuro. M. de Chateaubriand mostra o altar antigo, a religião do berço, a oração posta de joelhos diante da mãe, o velho padre encanecido pela proscrição vindo errar de novo sobre o túmulo dos antepassados, trazer aos tugúrios e o Deus exilado, o som do sino do berço, o hino do incenso, o mistério, a esperança, a consolação, o perdão; o coração era do seu partido; aceitam por profeta do futuro o poeta que bordava com tantas flores sagradas, e com tantas lágrimas santas o sudário do passado. Jamais a poesia fez uma tal conversão de corações pela magia da imaginação, e pela elegância do sentimento. Este livro assombra o mundo como uma voz saída do sepulcro. Pasma-se, recorda-se, chora-se, reza-se, não se raciocina mais. A França foi convencida pelo coração.

Desde este dia, M. de Chateaubriand tornou-se o homem necessário de todas as restaurações. Ele restaurou o Cristianismo e Deus nas almas: como não restauraria a monarquia e os reis em seus palácios? Caro à Igreja que remoçou com suas lágrimas; caro à aristocracia, cuja prescrição santificou; caro às mulheres, pela ternura de seus poemas em que a religião só lutava com o amor para divinizar

10. Massa adverte que o texto francês registra o contrário, pois a idéia original seria "além disso, com a poesia". Cf. Jean-Michel Massa, op. cit., p. 490. 
a paixão; caro à mocidade que ouvia pela primeira vez nesta poesia notas em que a natureza e Deus ressoavam como cordas novas adicionadas ao instrumento lírico do coração do homem: seu nome reina no santuário, no lar doméstico, no berço dos filhos, no túmulo dos pais no presbitério da aldeia, no castelo da vila, no leito dos esposos, no sonho do mancebo; a poesia tinha-se perdido no ateísmo; ele achou-a em Deus. A poesia será uma das forças reais deste mundo, enquanto o dom da imaginação for uma metade da natureza humana.

\section{$\mathrm{X}$}

M. de Chateaubriand voltou livremente à França para aí publicar o seu livro. Bonaparte, que era o poeta do passado também em ação, queria uma mão bastante rica de cores para dourar-lhe as instituições, os prejuízos, os prestígios sobre que fundava a sua força. Seu gênio vasto, mas não criador, - não era outra cousa que o mesmo gênio das restaurações.

Ele aspirava a reproduzir em si Carlos Magno, este criador de um tempo no fim do outro, o décimo século no fim do décimo oitavo. Enganava-se na data e remontava o espírito humano a oito séculos. M. de Chateaubriand convinha-lhe, e ele devia convir a M. de Chateaubriand. Era a mesma a idéia de ambos: M. de Chateaubriand era o Napoleão da literatura.

\section{XI}

O escritor não resiste às dádivas adiantadas do conquistador; foi nomeado secretário da embaixada em Roma, a capital do catolicismo restaurado, onde o tio de Bonaparte, o cardeal Fesch, era embaixador.

Esta subalternidade não satisfez por muito tempo o homem de gênio que reinava em sua pátria pelo talento: rompeu por mesquinhas contendas com este embaixador simples e rude de espírito. Napoleão desconfiava de toda grandeza natural que não dependesse dele exclusivamente. Afetou tratar M. de Chateaubriand como homem inferior nomeando-o ministro plenipotenciário em Lion $^{11}$, lugarejo de Valais perdido em um vale dos Alpes. Havia ao mesmo tempo favor e ironia em semelhante missão, e em uma tal residência marcada a um homem tal. Era Ovídio entre os Sármatas. Pode-se crer que M. de Chateaubriand ressentiu-se disso.

$\mathrm{O}$ assassinato do duque de Enghien que produziu a indignação da Europa nesta época forneceu-lhe uma nobre vingança.

Enviou a sua demissão ao matador poderoso. Era a declaração de guerra da honra ao crime. Esta demissão só era injuriosa na data. Todavia M. de Chateaubriand colocou-se desde esse dia diante da fortuna de Bonaparte. Não lhe recusou entretanto algumas frases aduladoras na época da sua eleição à Academia Francesa, como um passo de antemão para a reconciliação. O imperador respirou o incenso, mas a mão ficou ainda oculta. Distraído pela guerra, esqueceu o grande escritor, que pelo seu lado, parecia abrigar-se exclusivamente nas letras. M. de Fontanes, seu amigo, e um dos familiares do imperador, cobria-o contra toda a perseguição real. Graças a este intermediário, os dous grandes rivais de nomeada podiam sempre atar um ao outro suas fortunas. Os sintomas da decadência de

11. Embora a versão em português indique “Lion”, o correto é “Sion”. Cf. Jean-Michel Massa, op. cit., p. 490. 
Napoleão, tornada mais inevitável pelo excesso mesmo da sua tirania, feriam M. de Chateaubriand, que preparava em silêncio a derradeira arma com a qual queria feri-lo oportunamente. Era o libelo intitulado: Bonaparte e os Bourbons. Ele o trouxe muitos meses como um punhal - cosido no forro da sua roupa.

Descoberto este libelo, podia ser a sua sentença de morte. Era mais que uma conjuração, era um ultraje.

Este livro forte, mas odioso pois que caluniava o homem ferindo o tirano, elevou M. de Chateaubriand à linha dos favoritos mais acreditados da Restauração. Tornou-se o homem consular de todos os partidos realistas; excitava pelo jornalismo onde convinha o seu domínio, ora o realismo implacável, ora o liberalismo carinhoso, ora o antigo regime sem contrapeso, ora a conciliação capciosa tendo por eco o Jornal dos Debates, ou o Conservador, por escola a mocidade aristocrática, por móvel uma caprichosa ambição, e uma imensa personalidade, umas vezes vencido, outras vencedor, mas sempre certo de achar o favor público, afetando a perseguição, e retirando-se em seu gênio.

\section{$\mathrm{XII}^{12}$}

M. de Bonald, talento muito inferior, mas caráter muito superior ao de M. de Chateaubriand tinha, nesta mesma época, um nome igual; mas a sua popularidade misteriosa não ultrapassava os limites de uma escola e de uma seita; era o legislador religioso do passado encerrado no santuário dos tempos. Transmitia oráculos aos crentes, não se fazia conhecido do povo.

M. de Bonald era a mais nobre e a mais pura figura que o antigo regime pôde apresentar ao novo. Gentil-homem de província, cristão de fé, patriota de coração, realista de dogma, bourbonista de honra e de fidelidade, tinha reivindicado a sua parte na prescrição e na indigência durante a emigração; errou de campo em campo e de cidade em cidade fora da pátria, com sua mulher e seus filhos alimentados de seu trabalho; estudou a história, os usos, as religiões, as revoluções dos povos em sua calma e em suas catástrofes. Como Arquimedes, escreveu e calculou no meio do assalto dos homens e do incêndio europeu. Sua religião era sincera e submetida como que a uma ordem recebida de cima e não discutida. Ele extratava toda a sua filosofia dos livros santos; acreditava na revelação política, como na revelação cristã; remontava sempre de degrau em degrau até ao oráculo primitivo, Deus. Sua teocracia não admitia nem a dúvida, nem a revolta. Mas, como em todas as crenças sinceras e desinteressadas, não havia nele excesso, paradoxo ou violência; ele era indulgente e doce como os homens que se crêem possuidores certos e infalíveis de sua verdade; compunha com os tempos, os usos, as opiniões e as circunstâncias, nunca com autoridade. Seu caráter tinha a moderação do possível; teria sido o ministro sapientíssimo de uma restauração paciente, prudente e - circunspecta; ele possuía a sabedoria das suas opiniões. O hábito de meditar e de escrever tinham-lhe tirado o talento da palavra; ele era demasiadamente elevado e sereno para ser orador parlamentar ou popular; não falava, pensava na tribuna. Mas seus livros e suas opiniões escritas faziam dogma no partido monárquico e religioso; seu estilo simples, refletido, deslizando sem escuma e sem agitação, era a imagem de seu espírito. Respirava-se nele a honestidade e a candura da inteligência; a ele prendia-se

12. Na tradução da Marmota, a indicação da décima segunda parte do texto está faltando. 
como a uma doce e íntima conversação; tomava-se-lhe o hábito, e mesmo resistindo às convicções seguia-se arrastado pelo atrativo da boa fé no erro e do natural, na verdade. Sua conversação sobre tudo era atrativa. Era a confidência do homem de bem; M. de Bonald não era só para a França de então um grande publicista, era um pontífice da religião e da monarquia.

\section{XIII}

M. de Fontanes, depois da morte do abade Delille, passava em confiança pelo poeta sobrevivente da escola antiga do século décimo sétimo. Seu nome tinha uma imensa autoridade. Ele abrigava esta autoridade sob o mistério. Falava-se continuamente de poemas que ele nunca publicava. M. de Chateaubriand, seu protegido na época em que tinha necessidade de protetor, seu amigo depois, professava por M. de Fontanes a admiração que recusava à multidão de poetas do tempo. Deste poeta apenas se conheciam alguns fragmentos elegantes, puros, didáticos, sem originalidade, sem fogo, mas sem manchas, talento que desarmava a crítica, mas que não apaixonava pelo entusiasmo. M. de Fontanes distinguia-se mais nesta eloqüência de aparato, que Napoleão lhe fazia desenrolar nas grandes cerimônias de seu reinado, como a pompa do Império. Foi orador de corte e poeta monárquico desde o consulado até a Restauração. Precipitou-se ao novo reinado com mais ardor que conveniência. Poeta para os políticos, político para os poetas, elevado pelo favor dos dous reinados às mais altas dignidades do governo, gozava de uma consideração presente, de uma glória futura, envolvido em seu prestígio; inviolável à crítica, agradável à corte, acariciado pelos homens de Estado, revelando de tempos a tempos às academias, e aos eleitos das letras seus versos como uma complacência e seu talento como um favor.

\section{Três Tesouros Perdidos}

Uma tarde, eram quatro horas, o Sr. X. voltava à sua casa para jantar. O apetite que levava não o fez reparar em um cabriolé que estava parado à sua porta. Entrou, subiu a escada, penetra na sala e... dá com os olhos em um homem que passeava a largos passos como agitado por uma interna aflição.

Cumprimentou-o polidamente; mas o homem lançou-se sobre ele e com uma voz alterada, diz-lhe:

- Senhor, eu sou F., marido da Sra. Dona E.

- Estimo muito conhecê-lo, responde o Sr. X.; mas não tenho a honra de conhecer a senhora Sra. Dona E.

— Não a conhece! Não a conhece!... quer juntar a zombaria à infâmia?...

- Senhor!...

E o Sr. X. deu um passo para ele.

- Alto lá!

O Sr. F., tirando do bolso uma pistola, continuou:

— Ou o senhor há de deixar esta corte, ou vai morrer como um cão! 
- Mas, senhor, disse o Sr. X., a quem a eloqüência do Sr. F. tinha produzido um certo efeito, que motivo tem o senhor...

- Que motivo! É boa! Pois não é um motivo andar o senhor fazendo a corte à minha mulher?

- A corte à sua mulher! não compreendo!

- Não compreende! oh! não me faça perder a estribeira.

- Creio que se engana...

— Enganar-me!... É boa!... mas eu o vi... sair duas vezes de minha casa...

- Sua casa!

- No Andaraí... por uma porta secreta... Vamos! ou...

- Mas, senhor, há de ser outro, que se pareça comigo...

- Não; não; é o senhor mesmo... Como escapar-me este ar de tolo que ressalta de toda a sua cara? Vamos, ou deixar a cidade, ou morrer... Escolha!

Era um dilema. O Sr. X. compreendeu que estava metido entre um cavalo e uma pistola; pois toda a sua paixão era ir a Minas. Escolheu o cavalo.

Surgiu, porém, uma observação.

- Mas, senhor, disse ele, os meus recursos...

— Os seus recursos! Ah! tudo previ... descanse... eu sou um marido previdente.

E tirando da algibeira da casaca uma linda carteira de couro da Rússia, diz-lhe:

- Aqui tem dous contos de réis para os gastos da viagem; vamos, parta, parta imediatamente. Para onde vai?

- Para Minas.

— Oh! a pátria do Tiradentes! Deus o leve a salvamento... Perdôo-lhe... mas não volte a esta corte... Boa viagem!

Dizendo isto, o Sr. F. desceu precipitadamente a escada, e entrou no cabriolé, que desapareceu em uma nuvem de poeira.

O Sr. X. ficou por alguns instantes pensativo. Não podia acreditar nos seus olhos e ouvidos; pensava sonhar. Um engano trazia-lhe dous contos de réis e a realização de um dos seus mais caros sonhos. Jantou tranqüilamente, e daí a uma hora partia para a terra de Gonzaga, deixando em sua casa apenas um moleque encarregado de instruir, pelo espaço de oito dias, aos seus amigos sobre o seu destino.

No dia seguinte, pelas onze horas da manhã, voltava o Sr. F. para a sua chácara de Andaraí, pois tinha passado a noite fora.

Entrou, penetrou na sala, e indo deixar o chapéu sobre uma mesa, viu ali o seguinte bilhete:

"Meu caro esposo! Parto no paquete em companhia do teu amigo P... Vou para a Europa. Desculpa a má companhia; pois melhor não podia ser. - Tua E."

Desesperado, fora de si, o Sr. F. lança-se a um jornal que perto estava: o paquete tinha partido às oito horas.

— Era P... que eu acreditava meu amigo... Ah! maldição! ao menos não percamos os dous contos! 
Tornou a meter-se no cabriolé e dirigiu-se à casa do Sr. X., subiu; apareceu o moleque.

- Teu senhor?

- Partiu para Minas.

O Sr. F. desmaiou.

Quando deu acordo de si estava louco... louco varrido!

Hoje, quando alguém o visita, diz ele com um tom lastimoso:

- Perdi três tesouros a um tempo: uma mulher sem igual, um amigo à toda prova, e uma linda carteira cheia de encantadoras notas... que bem podiam aquecer-me as algibeiras!...

Neste último ponto, o doudo tem razão, e parece ser um doudo com juízo.

Machado d'Assis

\title{
Os Cegos \\ O Ceggo de Nascença e o Ceggo por Desgraça
}

Bem que muitas e valiosas opiniões se tenham já no mundo pronunciado a este respeito, submetemos hoje à consideração do público e seguinte mote de nossa composição, feito de modo que pode ser glosado sem dificuldade alguma.

\author{
Mote \\ Qual dos dous Cegos mais sente \\ O penoso estado seu: \\ O que cegou por desgraça, \\ O que cego já nasceu?
}

Dizem uns que o cego de nascença é mais feliz, porque vivendo na ignorância de tudo, não pode ter pesar de não ver, de não comparar aquilo que nunca viu, aquilo que nunca comparou; e que só aquele que já gozou o mundo, que tudo viu, que tudo admirou, é que, no estado de cegueira, por desgraça, sente mais a falta de vista.

Dizem outros, porém, que o cego de nascença, sem nada ter visto, sem nada ter admirado, seria, sim, mais feliz se vivesse na ignorância de tudo, e não em uma sociedade onde a cada instante está ouvindo fazer-se a pintura de cousas, de que ele não pode formar uma idéia; entretanto que, o cego por desgraça, forma idéia de qualquer cousa em que se lhe fala, por isso que, no seu tempo, tudo vira, e a idéia que de tudo ainda tem o satisfaz comparando o velho com o novo, o feio com o bonito etc. etc.

Debaixo destes dous pontos de vista podem as pessoas, mais ou menos habilitadas, mandarnos suas composições, quer em prosa, quer em verso, que as publicaremos pela ordem em que nos chegarem à mão. 
Como existam já muitos escritos a este respeito, aqueles dos nossos leitores que souberem de algum artigo ou artigos, que disso tratem, nos obsequiarão também remetendo-nos, traduzidos, por traduzir, ou copiados mesmo de obras em português, uma vez que não ocultem o nome do autor, do livro, ou do jornal de que os extraírem.

A questão, bem que muito filosófica, pode ser tratada segundo o sentir de cada um, uma vez que não se apresente edifício sem base.

\section{P. Brito}

\section{Os Cegos Resolução Filosófica A Demócrito}

O que é mais doloroso, ser-se cego de nascença ou cego por acidente? that is the question....

Como bem disse o Sr. Redator da Marmota, a questão apresentava-se essencialmente filosófica, e o grande campo para os sectários da doutrina espiritualista estava aberto com uma discussão toda metafísica; porém eu por demais amigo de galhofar, e pouco acostumado a manejar silogismos e espertezas da lógica, resolvi não entrar nesse debate, empenhando num campo inteiramente cerrado para meus hábitos e costumes, apesar contudo do desejo que tinha de também dar a minha humilde opinião a respeito; mas bem razão tinha aquele que disse: vouloir est pouvoir!

À vontade, essa eletricidade intelectual, fez-me lembrar que se eu discutisse rindo-me, ainda o fazia filosoficamente, pois o riso já foi o característico de uma escola de pensadores, e, portanto, animado com essa idéia tomei a minha pena ligeira de folhetinista, e comecei o meu raciocínio sobre a questão, desta maneira:

Se a vida é, como diz Bichat, a reunião dos fenômenos que triunfam da morte; se a vista, como diz Sthall, é a melhor cousa da vida; segue-se concludentemente que a cegueira, isto, é a morte da vista, é a aniquilação da melhor parte da vida.

O cego de nascença começa a vida sem essa aniquilação, isto é, não sofre essa subtração na sua força vital, portanto este argumento só serve para mostrar sofrimento no cego posterior ao nascimento, que a meu ver é mais digno de lástima.

Não ver, é uma privação; ter visto e não ver, é um castigo.

O cego de nascença idealiza as cousas colorindo-as melhor do que elas são, fantasia um mundo à sua guisa, identifica-se com ele, e portanto se visse a realidade, talvez essa desmerecesse à sua imaginação, e assim amasse mais o seu mundo. O cego depois tem refletida na alma as cenas que pasmou e quando se recorda delas é sentindo a morte de suas melhores ilusões! quantos soluços não custariam a Homero e a Milton as pinturas que, em suas cegueiras, fizeram nas imortais epopéias, de quadros tão belos da natureza que eles viram, guardaram e não contemplariam jamais?

O cego de nascença tem uma vida toda de espírito; a poesia, essa elasticidade da alma, como 
diz Lamartine, povoa o seu mundo de cenas fantásticas, que ele contempla uma realidade; e que melhor paisagista do que a poesia?

Entre a saudade e o desejo há uma grande diferença; a saudade supõe dor, o desejo apenas gozo; é o que se dá entre os cegos de nascença e depois de nascença; o primeiro deseja ver a luz, o segundo tem saudade da luz.

Quase faço um sermão de lágrimas, não é verdade, Sr. Redator? porém desculpe-me se menti ao meu programa; V. S. deve saber que hoje, o programa representa a antítese da execução, e portanto já devia esperar isso; mas para finalizar, sempre direi que acho mais digno de lástima o homem que já não vê, do que aquele que somente não vê...

Os fiscais e inspetores de quarteirão não são entes infelizes, e todavia são cegos de nascença, nunca vêem: ao passo que a nossa constituição é bem digna de dó porque houve tempo em que já viu, mas agora!... coitada! deu-lhe a gota serena e fez fiasco...

Todavia eu prefereria antes ser cego do que ter bons olhos e não ver como... o célebre astrônomo Lalande que dizia: J'ai visité toute letendue du ciel, et n'y ai point vu Dieu!

Razão por que ninguém me tira da cabeça que os pedestres descendem desse grande matemático... no que diz respeito à pouca vista...

Basta.

Jq. Sr.

\section{Os Cegos}

Esperávamos que alguém agitasse esta questão; e esperávamos na sombra, sem a ninguém comunicar as nossas intenções, os nossos pensamentos. Um artigo publicado no n. 929 da Marmota, decide-nos; vamos entrar na questão, expender as nossas idéias com a simplicidade e firmeza, filhas da convicção; certos da atenção e benevolência dos leitores.

O Sr. Jq. Sr., autor do artigo acima mencionado, à parte alguns absurdos, nada disse sobre a questão; entretanto, esperávamos o contrário ao começar a ler as primeiras linhas; ilusão que se desfez ao terminarmos o artigo. O que se diz nele? Nada. Nem mesmo a razão sobre o que o mesmo Sr. funda a sua opinião. Isto nem de leve ofende ao autor do artigo, que não conhecemos, mas de cuja capacidade não duvidamos; notamos apenas que o Sr. Jq. Sr., no meio de tanta cousa, não chegasse a uma conclusão, a uma conseqüência exata que fosse a base da sua opinião. $\mathrm{O}$ artigo apenas faz-nos saber que o seu autor é de opinião que o cego por acidente é o mais desgraçado. Por quê??

Entretanto a questão apresenta-se clara e filosófica:

- É o cego de nascença ou o cego por desgraça que mais sente o seu estado? -

O Sr. Jq. Sr. diz que, para o cego de nascença a vida começa sem a aniquilação da melhor parte da vida - a vista - e que portanto o cego por acidente, sofrendo essa aniquilação, é o mais digno de lástima. A conseqüência é errada, e está diametralmente oposta à única conclusão possível 
do princípio estabelecido. É pela razão mesma de que o cego de nascença não sofre a aniquilação da vista, que é o mais desgraçado. Ao nascer ele esbarra com a noite que o deve cercar durante a sua vida, esbarra com esse caos para que nunca há de soar um fiat. Como não ser desgraçado? Sem ter o gozo do cego por desgraça, que vê em parte pelos olhos do espírito, ele não pode fazer uma idéia exata dos objetos que lhe apresentais; e conseguintemente não pode compreender-vos, - gozar um pouco do que gozais - pelo exercício dos outros sentidos ou faculdades.

Continua o mesmo senhor, dizendo que o cego de nascença fantasia um mundo à sua guisa, e identifica-se com ele, idealizando e colorindo as cousas melhor do que elas são.

Isto importa um erro psicológico. Não é possível ao cego em questão criar esse mundo a essa guisa; e a razão é esta: - A criação desse mundo espiritual só pode ser fantasiada pela imaginação e pelo raciocínio. Estas duas faculdades desenvolvem-se no centro das idéias; as idéias são adquiridas pelos sentidos. Ora, sendo o cego de nascença totalmente estranho ao mundo físico, não pode receber idéias para povoar o seu mundo pela ausência do importante órgão da percepção visual: Como idealizar, colorir, e identificar-se com o seu mundo?

Ao cego por desgraça sucede inteiramente o contrário. O seu espírito conservando ainda as impressões recebidas pelos olhos exteriores, facilmente imagina tudo quanto lhe narrarem: e pode mesmo criar para si um mundo todo espiritual com as pálidas reflexões das suas recordações. Estas recordações, que são como que um crepúsculo no meio da sua noite, é que faz a grande diferença entre o cego por desgraça e o cego de nascença.

O cego de nascença, diz também o artigo, tem um gozo, o desejo de ver a luz; e o cego por desgraça uma dor, a saudade da luz.

Concordamos que haja no cego por acidente essa saudade, modificada porém pela ciência que ele tem do mundo físico. O que, porém, não aceitamos, é que o desejo no cego de nascença seja um gozo; nem mesmo em ninguém. O que há no cego de nascença é uma luta íntima, terrível, sangrenta, que abala o espírito, e fatiga as forças morais. Vivendo no meio de uma sociedade que a cada momento lhe está fazendo a pintura de todas as cousas, de todos os objetos, o cego de nascença sente o desejo ardente e voraz de ver, de conhecer esses objetos e essas cousas. - Quem pode dizer que isto é um gozo? Dai ao cego de nascença uma rosa, fazei-lhe aspirar o seu perfume; pensais que isto deve ser para ele um gozo? Não! aquele perfume suave e delicado, como um bálsamo filtrado por um dos mais belos poros da natureza, deve inspirar-lhe ardentemente o desejo de ver a flor que o exala. Deve ser bela, dirá ele, a flor que contém em seu seio este aroma que me embriaga o espírito e banha-me a alma na mais suave essência! Porém, o coitado não pode ver, nem fazer dela a menor idéia. Como aquela alma deve estorcer-se naquele desejo, naquela luta!

Há além de todas estas razões, que provam quanto é mais doloroso o estado do cego de nascença comparado ao cego por desgraça, um fato de muita importância, que nasce da ignorância total do cego de nascença relativamente ao mundo material.

Uma das provas mais eloqüentes, mais vivas, por isso que palpável, da existência de Deus é o universo, o mundo físico, esta natureza que se desenrola aos olhos do homem, colorida e perfumada por uma mão suprema. A inteligência humana reconhece que este desabrochar de flores, este reverdecer de campos, este suceder contínuo de estações, dias e noites, este existir de átomos, de insetos, que 
escapam à vista, e que nascem, vivem, movem-se, agitam-se, para o que é necessário haver músculos, pois sem músculos não há movimento, enfim este mundo grande e infinitamente pequeno, que se manifesta no trovão e no imperceptível caminhar dos átomos, este mundo harmônico - orgânico, majestoso, admirável; tudo isto, dizíamos nós, reconhece a inteligência humana que deve ter uma origem, que não pode estar em si, porque seria um absurdo, que não pode ser obra do acaso que nada produz, mas que deve nascer de um Ente Supremo, infinito, eterno. Este reconhecimento, que importa um dos pontos capitais da filosofia, e a base da religião, não pode ser operado senão pelas idéias recebidas pelos sentidos. Pode o cego de nascença sem uma só noção do mundo físico, esta grande manifestação da existência de Deus, fazer uma idéia exata da Divindade? Não o cremos.

E pois, mais uma vez está provado que é mais doloroso o estado do cego de nascença comparado ao cego por acidente, pois que este tem uma idéia de tudo o que existe pelos olhos do espírito e da memória.

Por enquanto é bastante o que acima expendemos; voltaremos à questão, talvez, e então seremos mais extensos. Estamos certos que o autor do artigo a que nos referimos há de ficar zangado com as nossas palavras, e talvez volte a falar sobre a matéria.

Aguardamo-lo. Entretanto, fique certo de uma verdade: nós não ferimos personalidades, mas sim argumentos: mesmo apesar da frase de Buffon: - O estilo é o homem.

As.

\section{[Os Cegos]}

RÉPlicA AO SR. As.

Chamado à fala pelo Sr. As. sobre um artigo, intitulado - Os Cegos -, que discutimos; não podemos resistir ao emprazamento do ilustre cavalheiro, apesar de repararmos que o mesmo senhor tenha ligado mais importância do que nós mesmo a esse ligeiro escrito, e que trata com mais interesse, do que apresenta mostrar um artigo humilde e obscuro como o seu autor. Pela nossa parte, declaramos que jamais refutaríamos idéias que fossem absurdas e que nada provassem; leríamos até ao fim o artigo que nos tivesse despertado a curiosidade; e vendo que nada havia nele digno de interesse, murmuraríamos apenas em voz baixa: - que lástima! o que é que isto prova?!

Entretanto, o nobre cavalheiro nem de leve nos ofende, ao contrário, trata-nos com a urbanidade que o caracteriza, e tem, portanto, toda a razão quando diz: - o estilo é o homem.

Sentimos desenganar ao autor do artigo em questão, que enganou-se quando disse que nos zangaríamos com os seus argumentos; viemos ao seu chamado para um combate franco, leal e sem prevenções. Para que armas envenenadas quando não se debate um ponto de honra, ou que tenha relação com nossa pessoa e brios?! fora o combate de D. Quixote e do moinho de vento...

Não viemos sustentar os nossos primeiros argumentos, viemos apenas mostrar a inconseqüência dos vossos, Sr. As. 
- Escutai-nos:

Declarais que o cego de nascença, logo ao primeiro passo na vida, esbarra com a noite que o deve cercar para sempre, noite eterna e sem a esperança de um fiat lux, e portanto, que deve ser muito desgraçado o seu penoso estado: isto não é procedente; vós colocais o caso em vós mesmos, e avaliais do prejuízo daquele que nascesse sem vista; repetimos uma vez, que assim não é que deve estabelecer a questão: o recém-nascido apresenta-se na vida sem uma faculdade; porém os seus primeiros anos são passados sem cuidados nem desejos; o pensamento não funciona nele com a força do raciocínio; quando suas idéias estiverem desenvolvidas, já ele está acostumado com essa noite eterna, ele não sabe o valor do tesouro que perdeu, porque nasceu e criou-se sem conhecer esse tesouro; porque, enfim, não fez comparações, e a comparação mata a unidade, como sabeis!

Quanto ao vosso sistema sobre as idéias serem exclusivamente adquiridas pelos sentidos, e que apresentais como uma razão de impossibilidade para o cego de nascença criar um mundo ideal; só vos responderemos que a teoria de idéias inatas é altamente filosófica, e que neste caso a sua aplicação é muito sensata.

Perguntais ainda se pode o cego de nascença, sem uma só noção do mundo físico, fazer uma idéia exata da divindade?! com efeito! é uma contingência muito mesquinha essa em que pondes as provas da existência de Deus!! é acabar com todas as idéias imateriais e em que se funda a crença dos espiritualistas sobre a divindade! é reconhecer a Deus, somente em suas obras, e fazer dependente de acontecimentos físicos, uma idéia toda dependente da alma!!...

Quiséramos ser mais longos; porém não nos faltarão ocasiões logo que o nobre cavalheiro, com quem discutimos, ou rebater melhor nossas idéias, ou der mais vida às suas... se é que tem poder de ressuscitar Lázaros.

Jq. Sr.

\section{[Os Cegos] Questão De Cegueira}

Ilmo. Sr. Paula Brito.

Apesar de ser muito filosófica a questão encetada por V.S.; contudo, peço-lhe licença para nela também entrar; tanto mais que, sobre filosofia, tenho cá a minha opinião muito diferente da geral.

Quanto a mim, Sr. Redator, a filosofia não se estuda: a filosofia nasce com o homem; a filosofia é antes uma faculdade, que uma ciência, ou então seja esta - o modo por que cada um aprecia as cousas morais e encara as materiais. - Isto dado, entremos em matéria, esforçando-me eu, para não abusar da bondade de V. S., em ser lacônica.

É a questão de saber qual dos cegos é mais desgraçado, se o de nascença, se o do acaso?

Ah! ambos bem infelizes são; mas o último deve sofrer mais. O primeiro tem curiosidade de ver o que nunca viu; o segundo, saudade do que viu. O primeiro diz: - Que pesar tenho de não 
poder ver! - O segundo: - Oh dor! Eu já não posso ver!... - O primeiro, naturalmente, dotado de imaginação fria ou pouco entusiástica, não pode sentir com tanta veemência como o segundo, cuja vista foi roubada por qualquer fatalidade, em uma idade em que, senhor de todas as suas faculdades, de todos os seus sentidos, tinha podido apreciar e visto as imensas belezas, as imensas magnificências que por todos os lados nos rodeiam!

- Quem, Sr. Redator, será mais desgraçado: - aquele que perdeu o amor e os afagos da pessoa amada, ou aquele que nunca gozou tal bem? - Certamente concordará comigo que o primeiro: não é assim? Pois, quanto a mim, os dous cegos estão no mesmo caso. O que perdeu a vista é mais infeliz do que o que nunca a teve. Quem nunca gozou, não pode ter saudades; e a saudade, Sr. Redator, é um dos maiores, senão o maior, dos tormentos da vida! A ventura passada mais nos amargura os sofrimentos presentes! Quem o negará?

Portanto, Sr. Redator, concluo que o mais desgraçado dos dous cegos, é o cego do acaso.

Alcipe

Rio, 27 de fevereiro de 1858

Questão proposta na Marmota n. 925, de 12 de fevereiro do corrente ano

\section{Os Cegos}

Perguntais, amigo Paula Brito, qual mais infeliz - se o cego de nascença ou se o cego por desgraça?

A resposta é difícil: - ambos são desgraçados.

Eu também vos perguntaria, quem mais infeliz: o pobre que vive sofrendo fome e frio, ou o desgraçado que existe lutando com uma moléstia medonha!

Mas, enfim, a resposta deve ser dada pelo caso da pergunta.

É mais infeliz o cego por desgraça.

O cego de nascença faz idéias dos objetos, forma imagens das cousas, e julga que essas idéias são verdadeiras, que seus pensamentos são certos, que são a cópia da realidade, e o seu espírito se satisfaz, e se contenta com isso; mas o homem que nasce vendo o sol com a luz tão brilhante, o céu com cores tão lindas, e com tantas estrelas, a terra com tanta beleza, e com tantas flores, o menino lindo como um anjo, e a mulher tão formosa, parecendo reunir no semblante todos os encantos do criador, esse homem se depois cega, se considera que os seus olhos não podem ver mais as obras divinas da criação, se percebe que vive em uma escuridão contínua, que a luz está morta para ele; o seu desespero há de ser imenso, julgando que os objetos que viu se hão tornado mais lindos, que a primavera há de estar sempre sobre a terra, e, entretanto, ele privado de ver tudo isso que já uma vez admirou!

Que dor, que desespero não há de ter o cego por desgraça! 
Dizei-me: o homem que nasce pobre não suporta mais facilmente a miséria, do que aquele que, tendo nascido em palácios dourados, vê-se depois com os andrajos do mendigo?

O homem que ao nascer traz uma chaga no corpo, não tem mais resignação para sofrer esse mal, do que aquele que, tendo nascido são, vê depois no seu corpo uma ferida medonha?

O homem que assim que viesse ao mundo fosse lançado em uma masmorra, não teria mais paciência para suportar os martírios da prisão do que aquele que, tendo nascido livre, fosse depois arrastado ao calabouço?

Não seria Adão mais feliz se nunca tivesse vivido no Paraíso, do que depois de ter gozado desse Éden ver-se privado dele?

Pois assim acontece ao cego de nascença: vindo ao mundo com os seus olhos fechados para a luz, acostumando-se a viver na escuridão, habitua-se a isso, ama por fim a noite dos seus olhos, pois todos sabem que o hábito modifica o homem, como as nuvens que rolam no ar modificam a cor do céu; mas o cego por desgraça viu e apreciou o mundo, e vendo-se depois cego, amaldiçoa esse véu negro que lhe encobre a vista, aborrece essa escuridão que o circunda.

Como não há de então, o cego por desgraça amaldiçoar essa névoa, que colocada nos seus olhos lhe apaga a luz?!

Dizei-me mais: o homem pela sua imaginação não pode fazer uma idéia mais bela de um objeto, do que na realidade ele é? Quantos, que ainda não viram as Tulherias, pensam que esse belo monumento não tem defeito algum? Assim o cego de nascença não pode conceber idéias mais grandiosas, mais lindas dos objetos do que os outros homens?

Um moço, cego de nascença, operado pelo Dr. Cheselden, quando recuperou a vista, dizia que julgava que seus pais eram mais formosos do que ninguém.

E essas idéias belas, essas imagens grandiosas que faz o cego de nascença das cousas, não deve consolá-lo um pouco?

Dizei-me ainda: o homem que nasce cego, que relações pode tomar? vivendo sempre com a noite, não pode entrar nos festins do mundo, não pode formar muitas amizades; ama só o seu Jáo que estende a mão ao povo pedindo uma esmola, e pensa só no seu cão, que preso a uma corda lhe vai mostrando o caminho; as suas idéias são imitadas; quase que não tem recordações, e assim vive no seu pequeno círculo; tem medo de dar um passo para não morrer nas trevas, e acha sempre boa a habitação que ocupa; mas o homem que nasce podendo ver as pessoas que o cercam, que torna-se um conviva das festas do mundo, que espalha as suas amizades, as suas relações, e que depois cega por desgraça, teme a isolação em que vive, chora pelos seus amigos, tem recordações tristes do tempo feliz da sua vida!

Que dor, que saudade não há de ter então do mundo o cego por desgraça!

O cego de nascença é como o enjeitado que não conhecendo o seu pai, não tem saudades dele; assim o homem que nasce cego não conhecendo o mundo, pouco se embaraça com ele; o cego por desgraça é como o velho que todo o dia chora pela sua mocidade! 
Questão proposta na Marmota n. 925, de 12 de fevereiro do corrente ano

\section{Os Cegos}

TrÉPlicA AO SR. JQ. SR.

Como esperávamos, o Sr. Jq. Sr. voltou ao campo; e desta vez, não para sustentar os seus argumentos, mas para refutar os nossos. Tencionando não estendermos com reflexões preliminares, vamos reunir todas as nossas forças para defender as nossas opiniões e os nossos argumentos.

Entretanto, não podemos deixar de declarar que, desde que alguém se apresenta em público por um qualquer órgão da imprensa, ligamos todo o interesse às suas palavras, porque o tomamos pelo que ele se apresenta. Isto seja dito em resposta à modesta censura do Sr. Jq. Sr.

Desde que S. S. publicou o seu primeiro artigo sobre os cegos, decidimo-nos a refutá-lo. Esta resolução, que não deixava entrever um único motivo de ofensa ao autor do artigo - tinha por alvo despedaçar os atavios sofísticos de seus argumentos falsos. Havia nisso um pensamento humanitário; - receávamos que espíritos menos fortes se deixassem impressionar por uma linguagem que tão bem soube dourar uma aluvião de paradoxos. Escrevemos, e adivinhamos logo que S. S. voltaria a falar sobre a matéria. O que não esperávamos, porém, é que os seus novos argumentos mais inconseqüentes que os primeiros, deixassem a questão no mesmo pé; e que aqueles que partilham as suas mesmas idéias, sofressem uma terrível decepção, tanto mais inesperada quanto que a tradicional capacidade e aptidão de S. S. era um forte baluarte contra todo o desânimo e fraqueza.

Com efeito! a refutação que S. S. dá aos nossos argumentos, em vez de destruí-los, dá-lhes mais força. Não há destruição possível quando o edifício assenta sobre bases colossais.

Convictos da nossa opinião, fortes em nossos princípios, todos os argumentos que se nos apresentarem contrariando-nos, serão destruídos com a violência das deduções evidentes, semelhante às escadas de montanhas do paganismo.

E pois, comecemos a análise do artigo do ilustre adverso.

O cego de nascença, diz S. S., acostumado desde infante com a sua noite, nada sente ao chegar à idade do raciocínio. Isto não é refutação ao nosso argumento; bem longe está de destruílo. Concedemos que esta argumentação tenha algum valor, mas apenas para provar o estado feliz e descuidoso do cego de nascença na época do berço, na época em que para ele o pensamento não funciona com a força do raciocínio, segundo a frase de S. S. Mas, desde que essa época passa, desde que começam as narrações da sociedade, este murmúrio para ele, como que de um outro mundo, aí principia esse desejo, essa luta, essas aspirações atrevidas sobre que reage a venda de ferro que lhe intercepta a luz, a vista, o mais precioso dos sentidos.

Argumenta o ilustre adverso que a ignorância do cego de nascença relativamente ao mundo material é uma vantagem sobre o cego por desgraça, que tem cabal conhecimento do tesouro que perdeu. Já refutamos isso no nosso primeiro artigo. Coloque-se o cego de nascença em uma solidão, em um deserto, e nós daremos a mão à palmatória; exceto os perigos de uma vida errante, nada há aí que o faça desgraçado; mas à face dos homens, no centro da sociedade, nunca! ouvindo continuadamente 
a descrição de cousas maravilhosas, ainda as mais triviais, das quais não pode fazer a menor idéia, ele deve sofrer um suplício mais terrível que o de Tântalo, o mais terrível dos suplícios.

Assim, pois, não procede a argumentação do nosso adversário. É verdade que S. S. pode dizer, para comprovar a sua asserção: o costume faz lei; mas nós lhe responderemos que não há lei possível no caso atual; a natureza é sempre a natureza: exigente e terrível quando se trata das suas atribuições. Negar isto, é negar todas as verdades palpáveis, todos os princípios evidentes.

Mais adiante, o nosso ilustre adverso fala em idéias inatas. Abstemo-nos de discutir este princípio de Descartes, que não admitimos; concordamos que hajam princípios e sentimentos inatos - idéias, nunca!

Entretanto, sejamos generosos e concedamos mesmo, apesar de paradoxal, a admissão desse principio. O que prova ele no caso atual? absolutamente nada. Não é pela ação dessas idéias inatas, na verdadeira acepção da palavra, que se deve operar esse mundo de que fala o Sr. Jq. Sr:: isso pertence à imaginação. Para fantasiá-lo e colori-lo, é necessária, absolutamente necessária, a presença de idéias sensiveis, de imagens de corpos. Ora, o cego de nascença se bem que tenha idéias sensíveis do mundo tangível, odoroso etc. não tem todavia, pela falta de órgão visual, os corpos e as imagens necessárias para a criação de seu mundo imaginário; logo não se dá no cego de nascença a idealização de um tal mundo.

Isto é evidentemente lógico; só uma obstinada vontade de discutir poderá negá-lo: estamos certos que o público sensato há de reconhecer a verdade destas deduções, verdade que só pode nascer de solidez de princípios certos e evidentes.

Mostremos, porém, como são sólidas as nossas opiniões - e como essa base não assenta sobre princípios falsos; concedamos que se dá essa hipótese, que o cego de nascença, contra todas as doutrinas filosóficas, creia esse mundo na sua fantasia: prova isso por acaso que seja menos penoso o seu estado? - Por ventura seria melhor para ele idealizar esses panoramas informes, pálidos, hipotéticos, reformados todos os dias; que gozar, admirar o mundo real, palpável, variado, sublime? A resposta salta aos olhos e da sua verdade convence-se o mais tenaz e obstinado espírito.

E, pois, esta argumentação acha-se totalmente destruída: ninguém a admitirá ainda, exceto o nosso adverso que, como um náufrago, tem de agarrar-se aos destroços de seu próprio navio.

O último tópico do artigo do Sr. Jq. Sr. é interessantíssimo. S. S. acusa-nos de materialista: e para prová-lo, lança mão de um dos sofismas mais reprovados; atribui-nos uma opinião que não temos, dizendo que admitimos e reconhecemos Deus somente nas suas obras, nós que dissemos que uma das provas mais vivas, por isso que palpável, da existência de Deus, era o mundo físico!

Ora, quem nos ler com atenção há de convencer-se da nossa inocência; assim como quem ler os artigos do nosso adversário, reconhecerá facilmente no seu autor, uma veneração fanática pelas doutrinas espiritualistas. Nós não somos nem espiritualista puro, nem materialista; harmonizamos as doutrinas de ambas as escolas e seguimos assim em ecletismo com o qual damos às mil maravilhas.

Quanto ao reconhecimento de Deus em suas obras, repetimo-lo, o cego de nascença não pode conceber uma idéia exata, clara, perfeita da Divindade; isto não quer, porém, dizer que ele não possa ter dela idéia alguma, pois como dissemos acima, equilibramos com mais perfeita harmonia o espiritualismo e o materialismo. 
Assim não acontece, porém, ao nosso adversário. Contra a filosofia de todos os tempos ele só encontra provas da existência de Deus na ordem metafísica. Isto e a admissão de idéias inatas são um sacrifício heróico ao espiritualismo que não podemos deixar de louvar. O que será então da fantasia caprichosa e romanesca dos poetas que reconhecem a mão de Deus em todas as suas obras?

Concluamos; cremos ter respondido satisfatoriamente ao Sr. Jq. Sr.; instar a fazer reviver todos estes pontos que acabamos de destruir seria uma sensaboria muito e muito desagradável. Confiamos que o Sr. Jq. Sr., para vir de novo falar sobre a matéria, procure outras argumentações, senão tão conseqüentes como as nossas, pela falsidade da opinião que admitiu, ao menos mais sensatas.

Se não respondemos mais em tempo é pela afluência de trabalho que nos pesa; algumas horas vagas que nos restam, ocupamos na conclusão de alguns trabalhos literários a que estas questões prejudicam um pouco.

Entretanto, até à vista.

As.

Questão proposta na Marmota n. 925, de 12 de fevereiro do corrente ano

\section{Os Cegos}

Ainda uma Resposta ao Ilmo. Sr. As.

Pela consideração e cavalheirismo que nos merece o Sr. As., voltamos ainda a questão - os cegos - para respondermos ao nobre antagonista que nos interpela. Já dissemos uma vez, e o colega teria lido, que o nosso primeiro artigo, escrito humoristicamente e num estilo ligeiro, conquanto apresentasse a idéia que nos domina na presente questão, no ponto em que encarávamos como mais infeliz o cego por desgraça, era contudo essa idéia revestida de argumentos adequados ao estilo, e não um verdadeiro estudo metafísico; entretanto mereceu ele as honras de uma refutação, e conquanto saíssemos a campo para replicar, declaramos imediatamente que o nosso segundo artigo era uma refutação das idéias do nosso opositor e nada mais, pois com efeito só tínhamos em vista destruir as proposições do Sr. As., que se não combinavam com o nosso modo de pensar; feito esse segundo artigo e tendo ele sido ainda repelido, vamos agora fortificar os nossos primeiros argumentos, robustecê-los de razões, pois não é possível deixá-los sob a sua primeira e ligeira forma, quando temos um adversário disposto a debater a questão filosoficamente, e com aquela erudição que lhe conhecemos.

Antes, porém, de passar adiante, devemos uma explicação ao distinto adverso.

O colega é injusto quando nos julga um espírito aferrado à escola espiritualista, quando as idéias que apresentamos não dão-lhe direito à tal suposição. Se admiramos em parte o idealismo de Mallebranche, e o panteísmo de Spinosa, não podemos deixar de curvarmo-nos à força da voz poderosa de Cousin, esse chefe da escola eclética na França; prezamos a metafísica de agora, que diverge 
um pouco da antiga, pois trata de separar a imaginação das percepções abstratas; o nosso reclamo, pois, sobre idéias inatas que o autor como que reprovou, não veio senão mostrar a possibilidade da criação de um mundo ideal para o cego de nascença, e não como uma profissão de fé nossa; essa idéia emitimo-la para atuar unicamente sobre quem nos referíamos - o cego de nascença, - finalmente, apresentamo-la para provar que ele poderia idear, sem ver, e como diz Chateaubriand: - que importa saber se recebo idéias pelos sentidos ou não?

Engana-se também o ilustre colega dizendo que o acusamos de materialista; não o julgamos crente como Xenófanes em que Deus e o mundo é tudo o mesmo: não o temos nessa escola por certo; quisemos apenas mostrar que a Divindade pode dispensar provas físicas. Ao contrário de nós, o ilustre colega é que mostrou pelo correr de seu argumento ter uma idéia falsa dos cegos natos, pois admitido o seu princípio sobre - influírem muito para a crença em Deus as provas materiais e visíveis - segue-se que supõe ele terem os cegos de nascença uma idéia pouco segura ou duvidosa de Deus; pois essas grandes provas lhes são vedadas, desconhece-as inteiramente. Será, porém, afirmável essa suposição? duvidamos muito.

O homem que cegou por acidente principia por ter sido vítima de uma moléstia, uma fatalidade, ou um desgosto; é esse o exórdio para os seus padecimentos posteriores, para a recordação do que gozou, comparações com sua atualidade, e as dores pela perda do bem que, como muito fielmente chama Camões:

aquilo que mais val

Quanto mais perdido for

O cego nato não sofreu esse começo doloroso, fisicamente falando; não é o seu mal uma conseqüência desastrosa, e, portanto, tem menos esse espinho nos seus sentimentos; não teve ele esses dias da transição da luz para as trevas, que deve ser o mais horrível dos males; não teve, finalmente, esse combate em sua razão para indagar a causa por que a Providência o tratou assim! Ao contrário disso, o cego de nascença tem a esperança - essa vida da alma; - pode encarar possível a sua regeneração, o que se não dá com aquele que, vendo o seu órgão vital quebrado e inutilizado em sua forma, não pode esperar que contra os dados certos e anatômicos, se dê, só para com ele, um milagre! E são será isto, quando não uma consolação para o cego de nascença, ao menos um tormento de menos?

Um ente acostumado a ter a luz como cousa de sua economia vital, e que a vê apagada, não sentirá uma maior coluna de desgosto do que aquele que sem uso desse bem, apenas sofre pela ausência, como por mais um gozo o que não desfruta?

Encaremos também que o cego de nascença ou não cura do futuro ou o entrevê como, já dissemos, suscetível de melhora: ama ao Senhor e espera em um Deus de misericórdia. O cego por desgraça, porém, pode tornar-se um espírito descrente e blasfemo; pois não acha justo o seu estado, embora fizesse por merecê-lo, por isso que o culpado nunca está convicto de sua culpabilidade, e portanto só crê no Eterno como em um Deus de vinganças.

E não será mais feliz a vida deslizada entre hinos de amor, do que entre pragas e maldições?! 
O nosso colega poderá resistir às nossas razões, poderá mesmo em consciência não se achar convencido, pois a questão é toda de sentimento e não de razões; porém nós julgamos que temos mais companheiros de crença do que ele. Aguardamos a sua resposta e o saudamos.

Jq. Sr.

Questão proposta na Marmota n. 925, de 12 de fevereiro do corrente ano

\section{Os Cegos}

Sucedeu o que esperávamos: o nosso adversário recuando passo a passo encontrou a parede a que o levaram os nossos argumentos sensatos e conseqüentes. S. S. fica, pois, impossibilitado de discutir na questão atual, pelo menos com argumentações da ordem das que tem posto em prática. Mitos nasceram e mitos foram parar à tumba, donde não sairão, nem mesmo na consumação dos séculos! A terra lhes seja leve.

Entretanto, para que nos não alcunhem de pedante, por cantarmos este pequeno epinício, e este sincero epicédio, filhos ambos do coração, demos a razão disso; razão que aliás é tão fácil de darse, como... proteger um menino bonito, politicamente falando, nesta nossa boa terra.

Agradecemos em primeiro lugar as palavras lisonjeiras do Sr. Jq. Sr. É para nós um problema a razão porque merecemos um tratamento como o que nós dá S. S. - E isto é tanto mais difícil de compreender-se, quanto que entre nós o folhetim é da câmara dos lords da literatura, isto é, a arena das maneiras ridículas, e das vaidades pedantescas.

Todavia pode explicar-se dum modo muito natural este fenômeno, queremos dizer esta ausência total de um orgulho parvo - em um homem que como S. S. empunha com hábil mão a pena ligeira e dourada de folhetinista. É que os corações bons e as almas simples jamais de conformam com esses prejuízos, com essas fumaças, - com essa idiotia perniciosa - que embota o espírito e mata os verdadeiros talentos. Honra, pois lhe seja feita.

Dito dito, entremos na questão.

Como dissemos, os argumentos de S. S. estão totalmente inutilizados. Ponto por ponto os destruímos, e o nosso ilustre adverso nem tratou de os fazer reviver! Parece isto uma evasiva na falta dos princípios, e de idéias: não é assim? Prove-nos o contrário.

É sensível a diferença que existe entre o segundo artigo do nosso adversário e o terceiro. Naquele há o calor, a viveza, a coragem; neste há a frieza, e o desânimo. S. S. parece estar convencido, senão da falsidade da sua opinião, ao menos da inconseqüência dos seus argumentos. Assim, o ilustre adverso toca de passagem nas suas idéias inatas, e nem de leve refuta os nossos raciocínios sobre a impossibilidade da criação de um mundo - colorido pela imaginação do cego de nascença. E na verdade: como refutá-los? Como provar que e mais feliz ser-se cego de nascença, que cego por desgraça? Seria querer provar, conseqüência imediata que o estado de ignorância é melhor que o da 
certeza; que o mundo insensível tem vantagem sobre o mundo sensível, e, conseqüência remota, que o mundo vegetal - impera sobre o animal, a planta sobre o homem; seria querer provar todos estes absurdos, palpáveis, evidentes; - seria chegar de conseqüência em conseqüência à destruição de todos os seus princípios. Ora isto seria uma derrota e uma decepção terríveis para os seus irmãos de crença, e S. S. de certo deixou-nos esse trabalho, cônscio talvez de que o faríamos com menos impiedade que o seu raciocínio.

Por aqui vê-se que o nobre adverso tinha fortes razões para não tratar da questãofilosoficamente: estava certo de que no fim do seu artigo acharia o contrário do que teria dito no começo; absteve-se de passar por este desgosto; fez bem.

Todo o artigo é assim. O ilustre antagonista ou deseja ou repete os mesmos argumentos sediços e insensatos. Para evitar uma repetição fastidiosa enviamos o leitor e S. S. para os nossos artigos passados - onde acharão uma resposta conveniente.

Entretanto não podemos deixar de dizer ainda duas palavras sobre um dos tópicos do artigo em questão.

S. S. nega que seja um espírito aferrado às doutrinas espiritualistas. Pode-se prová-lo sem ir muito longe. Dizer que a idéia de Deus e da sua existência é toda dependente da alma e não tem parte no mundo físico: não é aderir ao espiritualismo mais puro e mais absoluto? - Se negar isto, faz-nos crer que será então capaz de negar a mesma existência de Deus.

O Sr. Jq. Sr., adivinhamos, deve em todas as questões colocar-se no extremo, tem até gosto nisso. Se não admitisse as idéias inatas de Descartes, admitiria sem dúvida a tábua rasa de Locke; se não fosse espiritualista puro, seria um materialista perfeito; é um sistema especial.

Concluamos, e concluamos por uma vez. Depois do último artigo do Sr. Jq. Sr. não há discussão possível; exceto se tomando aspirações quixotescas tentarmos destruir o que já por nós se acha aniquilado.

Concluamos, pois. O ilustre adverso queira desculpar alguma palavra mais ou menos ofensiva que tenha escapado no meio da discussão, e sobretudo os erros deste artigo escrito ao correr da pena.

Voltamos outra vez ao silêncio donde jamais sairemos, exceto se formos impelido fortemente.

As.

\section{O Passado, o Presente e o Futuro da Literatura}

I

A literatura e a política, estas duas faces bem distintas da sociedade civilizada, cingiram como uma dupla púrpura de glória e de martírio os vultos luminosos da nossa história de ontem. A política elevando as cabeças eminentes da literatura, e a poesia santificando com suas inspirações atrevidas 
as vítimas das agitações revolucionárias, é a manifestação eloqüente de uma raça heróica que lutava contra a indiferença da época, sob o peso das medidas despóticas de um governo absoluto e bárbaro. O ostracismo e o cadafalso não os intimidavam, a eles, verdadeiros apóstolos do pensamento e da liberdade; a eles, novos Cristos da regeneração de um povo, cuja missão era a união do desinteresse, do patriotismo e das virtudes humanitárias.

Era uma empresa difícil a que eles tinham então em vista. A sociedade contemporânea era bem mesquinha para bradar - avante! - àqueles missionários da inteligência e sustentá-los nas suas mais santas aspirações. Parece que o terror de uma época colonial inoculava nas fibras íntimas do povo o desânimo e a indiferença.

A poesia de então tinha um caráter essencialmente europeu. Gonzaga, um dos mais líricos poetas da língua portuguesa, pintava cenas da Arcádia, na frase de Garrett, em vez de dar uma cor local às suas liras, em vez de dar-lhes um cunho puramente nacional. Daqui uma grande perda: a literatura escravizava-se, em vez de criar um estilo seu, de modo a poder mais tarde influir no equilíbrio literário da América.

Todos os mais eram assim: as aberrações eram raras. Era evidente que a influência poderosa da literatura portuguesa sobre a nossa, só podia ser prejudicada e sacudida por uma revolução intelectual.

Para contrabalançar, porém, esse fato cujos resultados podiam ser funestos, como uma valiosa exceção apareceu o Uraguai de Basílo da Gama. Sem trilhar a senda seguida pelos outros, Gama escreveu um poema, se não puramente nacional, ao menos nada europeu. Não era nacional porque era indígena, e a poesia indígena, bárbara, a poesia do boré e do tupã, não é a poesia nacional. O que temos nós com essa raça, com esses primitivos habitadores do país, se os seus costumes não são a face característica da nossa sociedade?

Basílio da Gama era entretanto um verdadeiro talento, inspirado pelas ardências vaporosas do céu tropical. A sua poesia suave, natural, tocante por vezes, elevada, mas elevada sem ser bombástica, agrada e impressiona o espírito. Foi pena que em vez de escrever um poema de tão acanhadas proporções, não empregasse o seu talento em um trabalho de mais larga esfera. Os grandes poemas são tão raros entre nós!

As odes de José Bonifácio são magníficas. As belezas da forma, a concisão e a força da frase, a elevação do estilo, tudo aí encanta e arrebata. Algumas delas são superiores às de Filinto. José Bonifácio foi a reunião dos dous grandes princípios, pelos quais sacrificava-se aquela geração: a literatura e a política. Seria mais poeta se fosse menos político; mas não seria talvez tão conhecido das classes inferiores. Perguntai ao trabalhador que cava a terra com a enxada, quem era José Bonifácio: ele vos falará dele com o entusiasmo de um coração patriota. A ode não chega ao tugúrio do lavrador. A razão é clara: faltam-lhe os conhecimentos, a educação necessária para compreendê-la.

Os Andradas foram a trindade simbólica da inteligência, do patriotismo, e da liberdade. A natureza não produz muitos homens como aqueles. Interessados vivamente pela regeneração da pátria, plantaram a dinastia bragantina no trono imperial, convictos de que o herói do Ipiranga convinha mais que ninguém a um povo altamente liberal e assim legaram à geração atual as douradas tradições de uma geração fecunda de prodígios, e animada por uma santa inspiração. 
Sousa Caldas, S. Carlos e outros muitos foram também astros luminosos daquele firmamento literário. A poesia é a forma mais conveniente e perfeitamente acomodada às expansões espontâneas de um país novo, cuja natureza só conhece uma estação, a primavera, teve naqueles homens, verdadeiros missionários que honraram a pátria e provam as nossas riquezas intelectuais ao crítico mais investigador e exigente.

\section{II}

Uma revolução literária e política fazia-se necessária. O país não podia continuar a viver debaixo daquela dupla escravidão que o podia aniquilar.

A aurora de 7 de Setembro de 1822 foi a aurora de uma nova era. O grito do Ipiranga foi o Eureca - soltado pelos lábios daqueles que verdadeiramente se interessam pela sorte do Brasil, cuja felicidade e bem-estar procuravam.

O país emancipou-se. A Europa contemplou de longe esta regeneração política, esta transição súbita da servidão para a liberdade, operada pela vontade de um príncipe e de meia dúzia de homens eminentemente patriotas. Foi uma honrosa conquista que nos deve encher de glória e de orgulho; e é mais que tudo uma eloqüente resposta às interrogações pedantescas de meia dúzia de céticos da época: o que somos nós?

Havia, digamos de passagem, no procedimento do fundador do Império um sacrifício heróico, admirável e pasmoso. Dous tronos se erguiam diante dele: um, cheio de tradições e de glórias; o outro, apenas saído das mãos do povo, não tinha passado, e fortificava-se só com uma esperança no futuro! Escolher o primeiro era um duplo dever, como patriota e como príncipe. Aquela cabeça inteligente devia dar o seu quinhão de glória ao trono de D. Manuel e D. João II. Pois bem! ele escolheu o segundo, com o qual nada ganhava, e ao qual ia dar muito. Há poucos sacrifícios como este.

Mas após o fiat político, devia vir o fiat literário, a emancipação do mundo intelectual, vacilante sob a ação influente de uma literatura ultramarina. Mas como? é mais fácil regenerar uma nação, que uma literatura. Para esta não há gritos de Ipiranga: as modificações operam-se vagarosamente; e não se chega em um só momento a um resultado.

Além disso, as erupções revolucionárias agitavam as entranhas do país; o facho das dissensões civis ardia em corações inflamados pelas paixões políticas. O povo tinha se fracionado e ia derramando pelas próprias veias a força e a vida. Cumpria fazer cessar essas lutas fratricidas para dar lugar às lutas da inteligência, onde a emulação é o primeiro elemento e cujo resultado imediato são os louros, fecundos da glória, e os aplausos entusiásticos de uma posteridade agradecida.

A sociedade atual não é decerto compassiva, não acolhe o talento como deve fazê-lo. Compreendam-nos! nós não somos inimigo encarniçado do progresso material. Chateaubriand o disse: "Quando se aperfeiçoar o vapor, quando unido ao telégrafo tiver feito desaparecer as distâncias, não hão de ser só as mercadorias que hão de viajar de um lado a outro do globo, com a rapidez do relâmpago; hão de ser também as idéias". Este pensamento daquele restaurador do cristianismo - é justamente o nosso; - nem é o desenvolvimento material que acusamos e atacamos. O que nós queremos, o que querem todas as vocações, todos os talentos da atualidade literária, é que a sociedade não se lance exclusivamente na realização desse progresso material, magnífico pretexto de 
especulação, para certos espíritos positivos que se alentam no fluxo e refluxo das operações monetárias. O predomínio exclusivo dessa realeza parva, legitimidade fundada numa letra de câmbio, é fatal, bem fatal às inteligências; o talento pede e tem também direito aos olhares piedosos da sociedade moderna: negar-lhos é matar-lhe todas as aspirações, é nulificar-lhe todos os esforços aplicados na realização das idéias mais generosas, dos princípios mais salutares, e dos germes mais fecundos do progresso e da civilização.

III

É, sem dúvida, por este doloroso indiferentismo que a geração atual tem de encontrar numerosas dificuldades na sua peregrinação; contrariedades que, sem abater de todo as tendências literárias, todavia podem fatigá-las, reduzindo-as a um marasmo apático, sintoma doloroso de uma decadência prematura.

No estado atual das cousas, a literatura não pode ser perfeitamente um culto, um dogma intelectual, e o literato não pode aspirar a uma existência independente, mas sim tornar-se um homem social, participando dos movimentos da sociedade em que vive e de que depende.

Esta verdade, exceto no jornalismo, verifica-se em qualquer outra forma literária. Ora, será possível que assim tenhamos uma literatura convenientemente desenvolvida? respondemos pela negativa.

Tratemos das três formas literárias essenciais: - o romance, o drama e a poesia.

Ninguém que for imparcial afirmará a existência das duas primeiras entre nós; pelo menos, a existência animada, a existência que vive, a existência que se desenvolve fecunda e progressiva. Raros, bem raros, se têm dado ao estudo de uma forma tão importante como o romance; apesar mesmo da convivência perniciosa com os romances franceses, que discute, aplaude e endeusa a nossa mocidade, tão pouco escrupulosa de ferir as suscetibilidades nacionais.

Podíamos aqui assinalar os nomes desses poucos que se têm entregado a um estudo tão importante, mas isso não entra na ordem deste trabalho, pequeno exame genérico das nossas letras. Em um trabalho de mais largas dimensões que vamos empreender, analisaremos minuciosamente esses vultos de muita importância decerto para a nossa recente literatura.

Passando ao drama, ao teatro, é palpável que a esse somos o povo mais parvo e pobretão entre as nações cultas. Dizer que temos teatro é negar um fato; dizer que não o temos, é publicar uma vergonha. E todavia assim é. Não somos severos: os fatos falam bem alto. O nosso teatro é um mito, uma quimera. E nem se diga que queremos que em tão verdes anos nos ergamos à altura da França, a capital da civilização moderna, não! Basta que nos modelemos por aquela renascente literatura que floresce em Portugal, ainda ontem estremecendo ao impulso das erupções revolucionárias.

Para que estas traduções enervando a nossa cena dramática? Para que esta inundação de peças francesas, sem o mérito da localidade e cheias de equívocos, sensaborões às vezes, e galicismos, a fazer recuar o mais denodado francelho?

É evidente que é isto a cabeça de Medusa, que enche de terror as tendências indecisas, e mesmo as resolutas. Mais de uma tentativa terá decerto abortado em face desta verdade pungente, deste fato doloroso. 
Mas a quem atribuí-lo? Ao povo? O triunfo que obtiveram as comédias do Pena, e do Sr. Macedo, prova o contrário. O povo não é avaro em aplaudir e animar as vocações; saber agradá-lo é o essencial.

É fora de dúvida, pois, que a não existir no povo a causa desse mal, não pode existir senão nas direções e empresas. Digam o que quiserem, as direções influem neste caso. As tentativas dramáticas naufragam diante deste czariato de bastidores, imoral e vergonhoso, pois que tende a obstruir os progressos da arte. A tradução é o elemento dominante, nesse caos que devia ser a arca santa onde a arte pelos lábios dos seus oráculos falasse às turbas entusiasmadas delirantes. Transplantar uma composição dramática francesa para a nossa língua é tarefa de que se incumbe qualquer bípede que entende de letra redonda. O que provém daí? O que se está vendo. A arte tornou-se uma indústria; e à parte meia dúzia de tentativas bem-sucedidas, sem dúvida, o nosso teatro é uma fábula, uma utopia.

Haverá remédio para a situação? Cremos que sim. Uma reforma dramática não é difícil neste caso. Há um meio fácil e engenhoso: recorra-se às operações políticas. A questão é de pura diplomacia; e um golpe de estado literário não é mais difícil que uma parcela de orçamento. Em termos claros, um tratado sobre direitos de representação reservados, com o apêndice de um imposto sobre traduções dramáticas, tem muito apelo, e convém perfeitamente às necessidades da situação.

Removido este obstáculo, o teatro nacional será uma realidade? Respondemos afirmativamente. A sociedade, Deus louvado! é uma mina a explorar, é um mundo caprichoso, onde o talento pode descobrir, copiar, analisar, uma aluvião de tipos e caracteres de todas as categorias. Estudem-na: eis o que aconselhamos às vocações da época!

A escola moderna presta-se precisamente ao gosto da atualidade. As Mulheres de Mármore - O Mundo Equívoco - A Dama das Camélias - agradaram, apesar de traduções. As tentativas do Sr. Alencar tiveram um lisonjeiro sucesso. Que mais querem? A transformação literária e social foi exatamente compreendida pelo povo; $\mathrm{e}$ as antigas idéias, os cultos inveterados, vão caindo à proporção que a reforma se realiza. Qual é o homem de gosto que atura no século XIX uma punhalada insulsa tragicamente administrada, ou trocadilhos sensaborões da antiga farsa?

Não divaguemos mais; a questão está toda neste ponto. Removidos os obstáculos que impedem a criação do teatro nacional, as vocações dramáticas devem estudar a escola moderna. Se uma parte do povo está ainda aferrada às antigas idéias, cumpre ao talento educá-la, chamá-la à esfera das idéias novas, das reformas, dos princípios dominantes. É assim que o teatro nascerá e viverá; é assim que se há de construir um edifício de proporções tão colossais e de um futuro tão grandioso.

\section{Machado d'Assis}




\section{BAGATELA $^{13}$}

Um dia do mês de maio de 1842, numa das últimas janelas de uma casa, que forma a esquina da rua Hautefeuille e da rua Serpente, - estava encostado um moço pensativo e melancólico.

Era - para usar da expressão da Torre de Nesle - uma bela cabeça que mais de uma rapariga teria visto passar em seus sonhos. Não uma bela cabeça, à maneira dos keepsakes, mas a pálida e inteligente fisionomia que se encontra muitas vezes nas obras de Lemud e em seu mestre Volfrand além de outras; bem o sabeis, leitor, este ouvinte atraente e grave do primeiro plano.

Percebia-se a vida da alma através do invólucro do corpo; e depois de contemplar aquele rosto que revelava o trabalho interior, não podia haver engano, e era força exclamar: - É um artista ou um poeta.

Henrique d'Auberseint era com efeito uma e outra cousa. Poeta, ele o era, como todas as criaturas felizmente dotadas e maravilhosamente organizadas - para o sofrimento. Porquanto a alma do homem inteligente, o coração do poeta, do artista ou do filósofo, é um alaúde que vibra harmonioso e sonoro ao sopro de todas as paixões humanas, grandes, fortes e belas.

Henrique era, pois, poeta. Mas sobre tudo era artista. Há, nos cais, nas - exposições de amostras de certos comerciantes, essas - fitas que não estão seladas com um nome, mas que são obras-primas. Uma obra-prima, assinada com um nome obscuro, será acaso uma obra-prima? Obscuro - quanto nos temos votado a este rude trabalho, orvalhado de suor do sangue, que se chama vida de artista obscuro quer dizer pobre. Henrique era pobre. Ah! implacável e madrasta natureza, bem fez aquele que te morde no seio para forçar-te a alimentá-lo! É andar - há de ser sempre feliz...

Henrique foi perturbado em seu cismar por um rumor de passos precipitados que se fez ouvir na escada. A porta da mansarda abriu-se bruscamente e entrou uma mulher.

- Bagatela! - exclamou o artista levantando-se e indo ao seu encontro.

- Onde está ele? - pronunciou ela com uma voz entrecortada pela fadiga, tomando a mão do mancebo e voltando para ele seus olhos obscurecidos pelas lágrimas.

Henrique não compreendeu ao princípio esta pergunta proferida de envolta com um soluço aos seus ouvidos inquietos, e durante alguns minutos ele contemplou Bagatela com admiração.

O semblante da moça radiava neste momento com uma beleza sobrenatural que não lhe era comum talvez. As grandes dores desfiguram, assim como as grandes alegrias.

Ela era bela, como uma bela virgem - com a elegância de maneiras e fineza de trato de uma parisiense. Era bela, muito bela!

- Mas o que acontece? Pergunta Henrique com uma ansiedade, que crescia de minuto em minuto.

— Mas desapareceu! Há dous dias que não se tem notícias dele! - respondeu Bagatela com

13. Informação no início da publicação do periódico: "O Sr. Machado de Assis, cujo nome e de cujas produções literárias já os nossos leitores têm conhecimento, pelo que de sua pena se tem publicado; mimoseou-nos com a seguinte tradução, que muito lhe agradecemos, cujo trabalho não é, como o título diz, uma [Bagatela]”. 
um ar sombrio. E se meus pressentimentos não me enganam, - ajuntou ela com um novo soluço e novas lágrimas - morreu!

Henrique soltou um grito.

- Tomai, - continuou a moça apresentando-lhe uma carta; lede depressa... eu vo-lo conjuro... Lede depressa... Acabam de ma entregar e é para vós... Reconheci a letra do nosso amigo... Estive a ponto de abri-la... Vêde... lede, Henrique, lede em nome do céu!

Henrique, trêmulo, com os olhos perturbados, abriu convulsivamente a carta que a moça lhe apresentara, e leu o que se segue:

É um morto que te escreve, meu caro Henrique, um verdadeiro morto, com a tinta negra do Estígio lago, e com uma pena arrancada à asa de uma qualquer ave noturna ou maligna, vampiro ou o que quiseres.

Não grites, não lamentes, não chores. As lamentações ensurdecem, e as lágrimas, vês tu, são uma parvoíce... O fato está já consumado, e não é mais possível uma volta:

- Quem volta de tão longe?

Faço-te a minha derradeira confissão, com certos conselhos e certas recomendações, que te peço tenhas sempre em vista.

Tive uma mãe, como qualquer porteiro, mas, conquanto saibamos sempre que procedemos de alguém - segundo a opinião de Brid’oison, estou, todavia, embaraçadíssimo quanto a afirmar de quem sou filho. É imoral, mas é verdade. Quanto ao meu nome nada sei de legal - pela ausência de qualquer declaração de meus autores nos registros da municipalidade. Mas eu tenho um, fantasiado, tomado ao acaso, entre os nomes do calendário: é - Máximo - nem mais, nem menos. Máximo - fui criado; Máximo - cresci; Máximo - vou desta para a outra vida. Tu sabes, além disso, que entre a rapaziada chamavame Max, porquanto a vida é tão curta... e inútil é alongá-la com três letras realmente inúteis.

Isto, quanto ao meu nascimento e quanto ao meu passado - um pouco semelhante às origens do Nilo. Não sabendo donde vinha, compreendes bem que eu nunca saberia onde ia. Um bastão tem sempre duas pontas; - um começo e um fim. Por muito tempo embalei-me na esperança de ter um fim e assemelhar-me, ao menos por aqui a um bastão. Eu acreditaria de boa vontade na eternidade das rosas, mas sempre me repugnou acreditar na eternidade da eternidade...

Se eu não conheci meus autores - em desforra conheci a vida - triste conhecimento, entre parênteses. Tiveste muita vez um espécimen de meu caráter fantástico e razoável. Eu era ao mesmo tempo o mais jovial rapaz, e o mais aborrecido indivíduo que se possa imaginar. Pamérgio forrado de Trenmor. Muitas vezes me levantava com projetos fantásticos que, postos em execução teriam feito arrebentar de riso a venerável estátua do Hospital. Muitas vezes entrava para casa com o semblante pálido, enrugado - e envelhentado horrivelmente. Lançavam-se à cama, enchia de fumo o cachimbo, fumava e atirava-o pela janela com uma raiva surda - sem respeito à sua cor poética de bistre. Nesses dias eu seria capaz de devorar um policial - com as bandoleiras, mas sem as botas, entretanto.

Não repares nos arabescos do meu estilo; estes gracejos são um vestido de 
arlequim - o coração palpita embaixo. Hoje, ao escrever-te, sinto-me disposto a rir e riome. Vale isso mais, acredita-me, do que atirar poeira ao céu, como os Gracos. É meianoite, acabo de encontrar alguns frangos éticos, fugindo de mim nas ruelas sombrias da Cité. Deu-me isso uma alegria! Por quê? Ah! sim, porque! sempre este ponto de interrogação!

Abro-te a porta da alcova dos meus sentimentos; não é a primeira vez, mas a última. Passava uma vida de tédio neste planeta, e além disso tenho um instinto viajor que me impelia sempre para as estepes infinitas do incógnito. Corro para lá, em teus braços, grande X., corro para lá, abre-os bastante!...

Estou, pois, a esta hora em marcha para a famosa viagem ao campo de que falam alguns. O abade de Saint-Pierre. Eu mesmo me forneci do passaporte inglês de Wester; não encontro, embora, alfândegas nas fronteiras da vida!... Meti audaciosamente a mão na urna do destino - e antes da minha hora - subtraí - o número... Eis tudo!

Agora falemos um pouco de ti - e dela, dela! dela!... Prometi-te um conselho, vou dar-to. Tu tens talento, Henrique, um grande talento: confirma-o perante a multidão, ela não achará dificuldades em acreditá-lo. Foste talhado por um Deus de Homero; em três passos atingirás ao termo, mas é preciso dar o primeiro; mãos à obra, os outros dous é apenas uma pernada.

Isto quanto ao conselho. Agora aos legados. Faço-te meu herdeiro universal. Tudo o que existe em minha oficina é teu. Sabes o que valem as telas de um artista morto? As minhas te ajudarão a viver. Vende-as!

Leva à Bagatela aquela pintura que eu fiz ligeiramente um dia em casa... Mostralhe esta carta, consola-a, ama-a, protege-a; responder-me-ás por ela.

Bagatela é a escolhida de meu coração... Um dia, em que ela estava triste e eu alegre, dei-lhe este nome de Bagatela que prevaleceu sobre o seu de - Gabriela. Peço-lhe que o conserve, é minha vontade; fui eu quem lho deu! Tu e ela foram para mim o mundo. Ela era o amor - tu, eras a amizade. Por que me não bastavam estas duas felicidades? Por quê? Ainda este maldito ponto de interrogação...

Assim, chego à recomendação que te queria fazer: - é grave, é um morto que ta faz, Henrique. Cumpre obedecer religiosamente. Que Bagatela seja tua irmã, Henrique; sê o seu protetor, seu amigo, seu pai - mas, nada mais. Pensai em mim algumas vezes e entretanto sede ambos fiéis à minha memória.

Dixi - Adeus, Henrique, adeus, Bagatela, adeus...

Máximo - vulgo o Velho!

“Todo como o velho Palma!...”

Morto! - murmurou Auberseint com uma voz sombria. - Morto sem me ter apertado a mão!

- Morto! repetiu por sua vez a moça - meus pressentimentos não me enganaram... Meu Deus! meu Deus!....

Pronunciando estas palavras, vacilaram-lhe os joelhos; a trepidação convulsiva de seu corpo tornou-se mesmo tão violenta que se Henrique não a tivesse retido nos braços ela rolaria pelo chão. 
- Gabriela! Gabriela! - gritou Henrique com um desespero cheio de solicitude.

- Ah! Max! querido Max! - soluçou Bagatela, - Max por que nos deixa assim?

- Como ela o ama! - murmurou Henrique. - Feliz morto!

- Ah! Henrique - tornou Bagatela - não sabeis o que perco eu na morte dele! Aquele nobre espírito, com o nobre coração... Eu lhe devia tanto, que nem todos os amores, e adorações bastariam para pagar-lhe!... Não o sabíeis, Henrique, pois que a sua delicadeza com semelhante confissão teria sofrido. - Ele levantou-me da calçada em que eu estava na rua, uma noite de inverno, eu tiritava de frio, tinha fome, e minha mãe acabava de morrer... Nossa história, a minha e de minha mãe - não vo-la contarei... é banal como a miséria, simples como a dor!... Eu estava pois na rua - exposta ao vento e à neve, desfalecida, semimorta e quase louca!... Máximo passou. Quando ele viu as lágrimas que corriam pelas minhas faces azuladas pelo frio, quando ele viu a minha miséria e o meu desespero, levou-me para a sua casa de artista, deu-me a chave dela, e pelo espaço de três meses, foi para comigo respeitoso, benfeitor e delicado. Procurou-me trabalho... Enfim, uma manhã bateu à minha porta - "Minha menina - me disse ele com tristeza - é preciso que nos separemos... Tenho uma má reputação, ao que parece, e é mister que a vossa não sofra... Não deveis desmerecer aos olhos das pessoas de bem... Aluguei para vós, em vosso nome, na rua do Oeste, uma pequena habitação - donde se descortinam os jardins de Luxemburgo e onde eu vos pedirei como um favor - a permissão de ir algumas vezes, como amigo...."

- “Oh! sempre, senhor Máximo! Sempre quando quiser... Eu não sou senão o que me fizeste: uma costureira modesta e feliz por viver do produto de seu trabalho... Esta ventura... eu vo-la devo... Deus vos abençoe por isso!" - Eis aqui o que eu respondi a Max com as lágrimas nos olhos, ajuntou Bagatela. - Bem sabeis, Henrique, como foi nobre e desinteressada a conduta do nosso amigo... Eu o amava - nunca lho disse... mas dir-lho-ia um dia se ele esperasse um pouco... Acreditou talvez na minha frieza, na minha indiferença, e contudo Deus sabe com que gratidão eu aceitaria a oferta de seu coração e de seu nome!

Bagatela calou-se. Era grande a sua emoção na evocação destas recordações...

Com efeito, ela amara tão ingenuamente Max! Como Gretechen ela fizera tanto por ele - que ele já nada lhe tinha a fazer... Porém Max tinha cousas singulares no cérebro... amava profundamente Bagatela... cercara-a sempre de cuidados delicados, de atenções ternas, mas sempre de mistura com uma espécie de respeito. Ela era para ele mais que uma irmã e menos que uma amante. Quando trabalhava, entre ela e Henrique, ele lhe lançava de vez em quando um olhar paternal e amoroso ao mesmo tempo, e murmurava depois: "Há de ser minha mulher!".

— Oh! Max! Max! murmurou de novo Bagatela.

- Ah! feliz morto! - murmurou de novo Henrique.

Na tarde desse dia, o jornal - O Mensageiro - publicou estas linhas: - "Acabamos de saber da desaparição de Mr. Máximo - vulgo o Velho - Mr. Máximo tinha há algum tempo acessos de febre ardente e tudo faz crer que em um desses momentos pôs fim aos seus dias... É uma perda imensa para a arte de que Mr. Máximo era um digno representante... Cumpre registrar a sua morte no martirológio dos grandes pintores - que o desespero, uma paixão continuada ou qualquer outra cousa levaram ao suicídio... Depois de David, morto longe da pátria, depois de Gros - agonizando no Sena, depois de 
Leopoldo Roberto, que se degolou em Veneza - depois de Gericault Sigalon, citamos o fim doloroso de Mr. Máximo!".

É assim que se escreve a História!

II

Alguns meses se passaram e - é mister confessá-lo para vergonha eterna deste pedaço de caoutchouc (borracha) que se chama coração humano - e cada dia levava consigo uma porção do amor e da amizade que Henrique e Bagatela votavam a esse pobre Max, morto sem dúvida, para os fazer felizes.

Toda a dor desaparece com o tempo por mais profunda que seja... cedo os pesares deixam de manchar o estofo cambiante da existência... Nem custa a desembaraçar a alma das recordações, que ligam ainda os vivos aos mortos... Assim, vai o mundo! Ontem, dor que parecia ser eterna, - sim, eterna como a aurora; hoje, esquecimento total das criaturas extintas, e cuja presença, além disso, seria importuna! E, realmente, os mortos são bem maçantes personagens em exigir uma memória sua sobre a terra. Para quê?

Todavia, não nos devemos apressar em deitar a primeira pedra da exprobração a essas duas pobres crianças. Max não estava totalmente morto na memória e no coração de Bagatela e de Henrique. Este último, sobretudo, quase às portas da miséria, apesar da herança que lhe deixara seu amigo, parecia acabrunhado por um remorso secreto de resto, bem fraco pela idéia de que Bagatela não partilhava seu criminoso amor. Primeiro que tudo, por uma dessas delicadezas do coração, que os amantes hão de compreender - tinha perdido o hábito de pronunciar esse nome de Bagatela sob o qual Max amara a mulher que ele amava também, posto que sem esperança. Em segundo lugar perdera ele também o hábito de se dirigir para o lado da casa de Bagatela.

Esta, por seu turno, não ousava queixar-se deste apartamento, mas lastimava-o porque o viu sofrer, e as mulheres que tem uma missão sobre a terra de mansidão, de comiseração, de afetuosidade, nunca faltam a ela. Bagatela sabia que Henrique era pobre e orgulhoso, e atribuía à sua miséria, que ele quisera suavizar, a dureza e grosseria que mostrava. Somente de vez em quando afligia-se a pobre moça com seu silêncio tenebroso, quando o interrogava delicada e amigavelmente sobre as causas dessa dor que o minava surdamente....

Henrique não podia confessar-lhe que era o seu amor por ela a causa única de seus tormentos e de seus combates de cada dia. Não ousava confessar-lho receando chamar sobre si sua cólera e desprezo... Belas, completas, e ingênuas eram aquelas naturezas! Como Henrique se assemelhava a esses D. Juans que inundam os salões e os bastidores, e que imaginam como Hans Svederlick, que não há honra nem favor que não possam colher, querendo para eles, "toda a galante flor!". Pobre namorado! pobre poeta! pobre artista!

Compreendendo, enfim, que aquele amor o mataria, Henrique resolveu um dia matar-se e acabar com um golpe suas irresoluções e sofrimentos. Mas, ele não queria morrer na rua para ser transportado e exposto - figura hedionda - sobre as hediondas tábuas da Morgue! Não!... a morte na sua pequena mansarda, ao pé de seus quadros, de suas obras: - na sua mansarda ainda perfumada com a presença de Bagatela; na sua mansarda, onde ele vivia com a imagem adorada, onde ela chorara; e onde lhe apertara a mão ao despedir-se! Essa morte, sim, valia a pena! 
Além disso, ele morria descansado sobre a sorte dessa mulher por quem ia morrer; porquanto no primeiro de cada mês, à noitinha, um velho, cujo semblante austero e melancólico causava respeito, apresentava-se em casa de Bagatela, dava-lhe um rolo de 150 francos, rendimento mensal que lhe deixara Max; depois retirava-se cumprimentando, mas sem proferir uma palavra.

Uma noite, pois, Henrique entrou em casa resolvido a por termo à existência que o acabrunhava. Acendeu a lâmpada, correu os ferrolhos da porta, que não se fechava de todo, e depois de algumas disposições testamentárias, tomou uma pistola que pusera ao entrar em uma mesa e carregou-a...

- Amo-a muito, murmurou ele penivelmente, para não persistir em minha resolução... Sede fiel à minha memória! - disse Max... serei fiel à sua memória... vamos... Daqui a poucos minutos estarei de jornada para a eternidade!... Ele gracejava nos seus últimos momentos... Max! Tinha essa coragem... Ah! é que era amado! Por que matou-se? Eu nunca ousara conceber esta esperança que faz minha alegria e suplício.... Adeus, pois, vós todos objetos queridos que vou abandonar, adeus!

Henrique inclinou orgulhosamente a cabeça. No momento em que colocava na fronte o cano da pistola, bateram na porta. Abaixou a arma e esperou. Bateram de novo, mas com uma violência inaudita. $\mathrm{E}$ a porta rodou sobre os gonzos...

- Henrique! que íeis fazer? - exclamou Bagatela, precipitando-se ao mancebo e arrancandolhe a pistola.

- Bem o vedes! - respondeu com uma voz surda - ia morrer!

- Morrer! Tu, Henrique! oh! não deves morrer... eu to proíbo!

Dous olhos e dous lábios que dizem eloqüentemente: - vivei! Têm o direito de serem ouvidos. Henrique sentiu desvanecerem-se as suas veleidades de suicídio.... sobretudo quando Bagatela ajuntou:

- Há muito tempo que eu adivinhei o teu amor - porque eu também te amava; sofrias, dizes tu? E eu? Eu! Acreditas então que eu não houvesse mister de coragem, ou antes de crueldade, para deixar-te assim esperar-me, sofrer e chorar? Combatias contra o vão fantasma de um passado que lá vai... lutavas com um remorso que não deve mais pesar em teu coração, agora que venho a ti, e te absolvo! Se é um crime esse nosso amor, meu doce amigo, tomo sobre mim a responsabilidade e a vergonha... Podemos ser felizes de hora avante, Henrique, pois que eu sou rica... um parente de minha mãe deixou-me uma herança... É uma benção do céu! Não teremos mais necessidade dos benefícios póstumos de Máximo.

Mr. Heine tem razão: "Todos sabem o que são cacetadas; mas o que é o amor, todos ainda ignoram!"

— Gabriela! - respondeu Henrique com um desespero misturado de tristeza. - Fugi, deixaime só... Há entre nós uma barreira que não podemos transpor... a lembrança de Máximo?

- Mas tu não me amas, Henrique?

— Não te amo! mas não é por ti que eu quero morrer? deixa-me... não quero ser perjuro!... vai-te!

- Ficarei aqui! - disse Bagatela com uma voz resoluta. - Há oito dias que te espero... oito séculos! pois que eu os contei... Tu não me procuraste... procurei-te eu... Venho dizer-te: - separados, éramos infelizes; reunidos.... 
— Oh! não acabes, Gabriela...

- Então morramos ambos... morramos...

- Ainda não, meus filhos - disse uma voz.

Bagatela e Henrique voltaram-se e viram, a primeira com medo, o segundo com espanto, aproximar-se um velho, cujo casacão pardo e cabelos brancos tinham um ar respeitável.

- O desconhecido! - murmurou a moça.

- Senhora, eu vos saúdo - disse o velho com uma voz trêmula e um pouco desfalecida. Bom dia, Senhor! estão ambos espantados... que tínheis! queríeis morrer, meu jovem amigo? Ah! fora com isso! é bom para os maníacos, e vós tendes juízo.

- Ah esta voz! Esta voz!... - exclamaram Bagatela e Henrique.

- É a de um homem que vos ama e quer a vossa felicidade, meus filhos... - retrucou o velho; - eu soube apreciar-vos ambos, há bastante tempo, posto que pouco me conheceis. Mr. Máximo, de quem fui amigo outrora, deixou-me o cuidado de velar sobre vós... Obedeci-lhe religiosamente...Vós que sois tão dignos um do outro, - (aqui a voz do velho fez-se um pouco irônica, o que não notaram os nossos amantes; tão ocupados estavam em recordar-se onde tinham ouvido essa voz tão fresca e suave ainda, apesar de seu abalo tremor de ancião)! Vós que sois tão dignos um do outro... ides tocar a meta da ventura! Eis aqui o vosso dote... não é considerável.... porém Max ficará satisfeito - lá em cima, se o aceitardes... É a última recordação que ele vos dá... Minha missão está terminada... O que vos peço ainda, em nome de Max, é de vos lembrardes algumas vezes, de vez em quando, quando não tiverdes outra cousa a fazer... nas vossas horas de tédio, ou de prazer, que um homem existiu, que vos criou, e levou consigo a consolação de ter ao menos as vossas saudades... é bem pouco uma recordação... e bem pouco uma lágrima... Fazei algumas vezes essa melancólica esmola dos vivos a um morto, que só tem aqui na terra uma preocupação: - a vossa ventura. Adeus, só me vereis ainda uma vez, no dia do vosso casamento; até mais viver, meus filhos e... até mais ver!...

E sem esperar uma resposta de Bagatela ou de Henrique, o velho desapareceu.

- Henrique, murmurou Bagatela com uma doce melancolia. - Henrique... bem o vedes... Nada mais se opõe à vossa ventura... Mas não vos quis legar um remorso...

Cousa estranha! - justamente em razão daquela absolvição que Max dera, de além-túmulo aos seus criminosos pensamentos, Bagatela e Henrique sentiam a consciência agitar-se, e apenas o artista morto levantava os seus escrúpulos eles renasciam mais vivos em suas almas...

— Oh! Max valia mais do que eu! - respondeu Henrique, voltando a cabeça, para ocultar à Bagatela a vista de uma lágrima que lhe resvalara furtivamente na face.

\section{III}

Um mês se tinha passado e em uma capela da Igreja de S. Sulpício, um padre abençoava dous jovens corações que tomavam diante de Deus o cargo de se amarem até a morte.

A um canto da capela estava um velho imóvel, com o pescoço estendido, que seguia com o olhar febril e quebrado cada movimento dos novos esposos que eram Bagatela e Henrique... Apenas a moça pronunciou corando de ventura o sim fatal, o velho estremeceu e a sua fisionomia exprimiu uma angústia dolorosa... 
Terminada a cerimônia dispersou-se a multidão. Bagatela estava radiante com o vestido azul do céu que parecia abençoar esta união e sorrir a esta festa. Henrique tinha por momentos, um ar pensativo e triste quando subiu para o carro, procurou e fez procurar por toda parte o velho; mas ele tinha desaparecido.

Enquanto os noivos se iam de seu lado contentes e brilhantes, ele apressava o passo com um ar sombrio, para chegar mais depressa.

Subiu uma escada de uma casa da rua dos Mártires, abriu uma porta e achou-se em uma oficina povoada de quadros, de estátuas e objetos de arte. Parou então, pôs a mão sobre o coração e contou as pancadas - Tudo está acabado! Murmurou ele com uma voz quebrada. - Ela e ele são felizes... Está bem...

E ficou entregue a uma meditação profunda que tinha por fim incessante uma determinação terrível.

— Nada de saudades estéreis! Nada de desejos quiméricos! - disse ele contemplando com olhar quebrado e resignado as nuvens que purpureavam o horizonte - lá vai o tempo das saudades e desejos... agora é a agonia... é a morte.... a morte! Oh! ela já está em mim... em mim todo!

E pôs a mão sobre a fronte!

- A inteligência, esse archote soberbo que irradia isoladamente ao lado do próprio sol?... Está apagada em mim...

Pôs a mão no coração:

— O coração, esse diamante precioso que nada altera... Meu coração! Quebrou-se em mil pedaços, como vidro...

Sorriu amargamente e continuou:

— Ah! os cantos de meu coração, e as marcas da minha vida são como os cipós da Via Apiena: não há mais que cinzas e aqui jaz! Sobre os destroços de meus amores e de minhas esperanças, só tinha de dormitar agora... Ah! a vida é feita de abrolhos e espinhos... Pobres ovelhas que o invisível pastor leva ao matadouro da morte, deixam lã a cada espinheiro, sangue a cada fonte de pedra... Pus o dedo sobre a ventura e a ventura fugiu-me para não voltar mais....

As divinas promessas do amor esvaneceram-se ao sopro gelado da indiferença... como eu era insensato! Crer na coragem de Henrique e na virtude de Bagatela!... Oh! queridos ídolos derrocados! Mas para que inventar Galatéas impossíveis? Por que quis apoiar a ventura de toda minha vida na areia movediça das paixões? - Quis, fatal pensamento! - submeter o amor de um e a amizade de outro à pedra de toque da ausência, e essa experiência provou-me o egoísmo dessas duas afeições sem as quais eu não podia viver... No fundo da ânfora onde as lancei ambas, resta um pouco de ouro puro e muita terra...

Não me amam mais, não me podem mais amar... E é tal o desencanto horrível de minha alma que nesta hora solene chega a duvidar que eles me amassem!... Mas que importa? Eu os amava, eu os amo ainda, ingratas crianças que me esqueceram tão depressa!... E a sua virtude me é cara, apesar de haver quebrado a minha.... Ah! a ventura! a ventura! - repetiu ele com violento furor - a ventura!... por ventura nós a conhecemos - nós os eleitos, os predestinados, os gloriosos, cuja vida é um calvário de estações dolorosas... A ventura nunca vem cedo; chega mesmo tarde 
demais. E um viajante descuidado e fantástico, que não sabe onde vai, onde deve comer, onde deve dormir, e que uma noite vem por fantasia bater à nossa porta. Mas já a velhice cá estava: a cabeça está calva, os olhos sombrios, a boca fechada; nós nos habituamos à imobilidade da sepultura, pela imobilidade da idéia. Todavia abre-se a porta a esse viajante estouvado e falador que para vir à nossa casa solitária toma um caminho mais longe... que retardou-se na viagem a cercar com as mãos as cinturas das jovens aldeãs encontradas, e a contar-lhes loucas histórias que as fizeram corar - de prazer! Abrimos a porta mas, rosnando; porque temos reumatismos: abrimos rosnando e tossindo, escandalizados das risadas intempestivas e da alegria extravagante desse hóspede, cuja vinda, que nos importuna tantas vezes, há bom tempo saudamos com efusão e gratidão... Não lhe compreendemos o falar... Já nos é um estrangeiro; mais que um estrangeiro mesmo, um inimigo; porque sua presença agora em nossa casa é uma ironia amarga, é um insulto. Mas não somos maus; não sabemos sê-lo; a dor habitua à bondade; e em vez de dizer a esse estranho que nos perturba o sono de ancião, batendo precipitadamente na porta fechada de nosso coração: "Já não vem a tempo!” - dizemos-lhe melancolicamente: - “É bastante tarde!" - Ah! cousa terrível... cousa horrível.... a ventura!

Durante um instante ficou ele com a cabeça entre as mãos crispadas; depois continuou com os olhos mais úmidos de lágrimas, porém mais enternecidos:

- Ouço soar em meu coração sinfonias inebriantes da mocidade, como um alegre concerto de vozes amadas... Ouço minhas alegres e frescas recordações de mancebo bater carga e rolar louca e impetuosamente por meu pobre cérebro... Ah! Toque insensato, amante risonho dessas recordações, dessas sinfonias me fazem mal!... Quero dormir o meu último sono, embalado pelo pensamento de que meu fantasma doce e triste atravessará talvez a vida de Henrique e Bagatela, e deixará um vestígio perfumado em seus corações.... Ah! ainda vêm ver, por que tentei essa prova maldita?... Antes de morrer experimentei a morte... Magoadora experiência! não sei se devo alegrar-me com ela, pois que eles são felizes, ou entristecer-me uma vez que morro! Oh! meus ídolos! Meus ídolos amados, caístes do pedestal em que vos elevei!... Eu devera morrer logo... teria levado à campo, crença, fé, ilusão!... não assistira à tua fraqueza, Henrique! não assistira à tua queda, Gabriela!...

Depois, desembaraçando-se do vestuário do velho que o incomodava, Max dirigiu-se pálido, grave, com a fronte carregada de idéias sinistras, para o fundo da sua oficina e para diante de uma tela branca que parecia esperar dele o movimento e a vida...

O rosto viril do artista refletiu, nesse instante, as torturas sem nome, as angústias horríveis, as dores inauditas que lhe rasgavam a alma desde o dia em que voluntariamente deixara Henrique e Bagatela.... Estava acostumado ao uso das decepções como Mitridates ao uso dos venenos; mas desta vez a dose era forte demais: matava-o!...

Nesse instante, ele odiava a vida com todas as forças que lhe restavam... desenganado deste mundo, chegava quase os lábios a taça fatal quando o vento lhe trouxe o eco fraco de um canto lançado no espaço. Pôs-se a escutar. A voz dizia: 
Nem um raio de sol desceu-me aos prados!

Veio a dor às campinas da esperança

Como vai joio ao trigo.

— É a voz de um poeta! - murmurou Max com um melancólico sorriso. - Não sou só eu a sofrer!

Chegou-se depois ao seu cavalete, tomou os pincéis e na tela colocada em frente dela construiu em uma hora, que passou como um relâmpago - o poema melancólico e pungente de sua vida despedaçada ainda no começo... Evocou por um momento os dous entes adorados que tinham vindo um após outro cravar-lhe o punhal no coração... E essa tela animou-se como por encanto! Iluminou-se de reflexos fantásticos e vertiginosos! Max dava assim o derradeiro esforço de seu gênio, o último grito de sua alma, a última vibração de seu coração...

Mas esse esforço sobrenatural devido à febre e ao desespero, esmagou-o.... Ele arrastou-se até a janela para contemplar ainda uma vez o céu que lhe negava, como suprema consolação, fechar os olhos no seio de uma mulher, e nos braços de um amigo; palpitava-lhe o peito convulsivamente...

Grossas nuvens pardas, levadas por um vento este acumulavam-se no horizonte como uma massa de neve. $\mathrm{O}$ sol, em meu ocaso, espalhava sobre a cidade uma cor sombria em harmonia com as sombrias idéias do artista...

- Vamos! - exclamou ele voltando à mesa onde depusera ao entrar um pequeno frasco contendo um licor escuro. - Que o sacrifício se consuma! Agora que todas as afeições estão mortas, que as minhas ilusões estão extintas, vou extinguir-me como elas, como elas vou morrer.... O aventureiro Gabor tinha razão: - "A vida é uma caçoada amarga!...”

E de um trago, o heróico artista absorveu o licor do vidro que decompôs-lhe o semblante rapidamente.

Corria-lhe o olhar sangrento e úmido de um a outro objeto, roçando de leve muitas recordações que se prendiam a duas criaturas queridas e amadas demais.

De repente, esse olhar moribundo parou na tela deslumbrante em que seu gênio lançara a última palavra... Parecia-lhe que legar aos vivos, aos indiferentes, aos felizes o admirável poema que ele esboçara seria um profanação, um sacrilégio, uma impiedade e reunindo então as poucas forças que lhe deixava o veneno, arrastou-se penivelmente até o cavalete, tomou uma faca e em sublime e último esforço rasgou e despedaçou freneticamente a tela... Depois seus braços se torceram, os dedos se lhe crisparam, soltou um grito surdo, um grito de angústia e de saudades supremas que o eco repetiu.

- Tudo acabara. - 


\section{Cousas Que São Maçantes}

Ler um prólogo extenso,

Conversar com um surdo,

Conversar com um velho sem dentes.

Questionar com teimosos.

Subir escada de muitos degraus.

Ouvir ler um gago.

Conversar com demandistas.

Passear em estradas que tenham areia e pó!

Ouvir tocar o realejo.

Ser sorteado para o júri.

Assistir a representação de um drama mal escrito, e muito extenso.

Ir a ofícios de defuntos.

Ir ao teatro lírico e aturar a voz de um cantor homem rouco e que nunca foi cantor.

Ouvir ler um poema em três volumes.

M. de A.

\section{MADAlENA}

Romance original por M. de A.

\section{Capítulo I}

Confissão de Moça

A Praça da Constituição recebeu esse nome por decreto de 2 de março de 1822, satisfazendo assim o Príncipe Regente o pedido patriótico do Senado da Câmara, que em ofício de 6 de fevereiro do mesmo ano, pediu a S. M. Real o Príncipe, que ordenasse que se desse a essa praça a sobredita denominação.

Outrora foi conhecida essa praça pelos nomes de Campo da Lampadosa, dos Ciganos, e de Praça do Rocio.

Aformoseada pelo vice-rei Luís de Vasconcelos, recebeu em 1813 a 1814 um calçamento regular, e apresentava no centro uma coluna de pedra chamada o Pelourinho.

Em 1832 residia em uma casa térrea dessa praça um empregado público chamado Fernando.

Fernando era homem honrado, honesto, de caráter nobre e firme. Para ele a honra era um culto, uma religião, julgaria um crime o faltar a sua palavra. Era um D. João de Castro moderno.

Fernando tinha o rosto moreno, barba crescida e preta, olhar penetrante e sagaz, nariz afilado, 
cabelos começando a esbranquecer e 45 anos de idade. Era viúvo; há 10 anos que perdera sua mulher, a que amara tanto como a Madalena, sua filha, retrato vivo e belo de sua mãe.

Madalena era a consolação, as esperanças e o anjo de seu pai. Quando Fernando se sentia triste, quando o pesar fechava-lhe o coração, bastava a presença dessa moça para o pobre pai mostrar um riso nos lábios e dizer-se satisfeito de sua sorte.

E Madalena quanto era boa e afável para com seu pai! Se o via triste mostrava-se carinhosa, sorria-se, cantava ou começava a fazer alguma leitura, que o pudesse distrair e consolar.

Pela bondade de seu coração, pelo seu gênio alegre e pela sua virtude, era Madalena estimada e adorada por todos. As moças que a viam ficavam sendo suas amigas. Todos gostam dos anjos, e adoram as santas.

Em uma tarde estava Madalena fazendo um trabalho de lã para oferecer a seu pai, quando ouviu bater na porta; era uma sua amiga, que vinha visitá-la.

- Adeus, Madalena, o que fazes?

- Algumas flores de lã para dar ao meu pai.

- Mas o que é isso? Esse rosto de anjinho, que anda sempre risonho, mostra hoje tanta tristeza, sem dúvida são saudades...

- Não sei o que sinto, mas parece que o coração quer anunciar-me alguma desgraça.

- Já sei, passaste a noite lendo algum romance triste, e estás agora pensando, que é verdade tudo o que os romancistas escrevem.

- Não acertaste, mas descansa, senta-te, Laura.

- Desejo saber já a causa da tua melancolia ou então retiro-me para não te afligir mais.

- Ora, Laura, estou triste porque estou triste.

- Mau. Isso é razão de cabo d'esquadra ou de frade Bernardo!

- Pois bem, sabes o que me entristece?

- Pior... Pareces que tens a cabeça lá pela serra dos Órgãos?

- Conheces o Dr. Cláudio?

- Já foi meu médico.

— Esse homem vem todos os dias à nossa casa e ontem lembrou-se...

- De quê?

- De pedir-me a meu pai em casamento!

- Pois um velho de 60 anos ainda pensa em casar?

- Meu pai é seu amigo e veio consultar-me sobre essa união.

- E o que lhe disseste?

- Que não era de meu agrado ser esposa desse homem, que nunca o poderia amar, mas que desejaria sempre satisfazer as vontades e desejos de meu pai.

- E o que fez o teu pai?

- Pediu-me que refletisse melhor, e disse-me que breve viria saber a minha última opinião.

- É assim; pensam que o coração da mulher é como a tela, onde o pintor pode apresentar qualquer retrato. Às vezes nos querem impor um marido, assim como obrigam a criança a decorar a lição. 
- É verdade, minha amiga. E enquanto se tem o coração livre, enquanto não se sabe ainda o que quer dizer a palavra - amor - pode ser indiferente o aceitar este ou aquele noivo; mas quando o nosso coração já não é nosso, quando há um sentimento vivo e ardente, que se tem apoderado de nossa alma; quando a mulher compreende o que é amar, e que em seus olhos, em seus risos, em suas lágrimas, ela declara que ama e que é amada, então é impossível dizer-lhe: - deixai de amar a esse que agora adorais; aquele é que deve ser o vosso noivo. Ah! é impossível, Laura, porque o primeiro amor fica gravado no coração da mulher, assim como a estrela que persiste sempre no céu.

- E amas muito, Madalena?

- Amo, como pode amar um coração de 18 anos, como se ama a luz que nos dá vida e alento, como os anjos amam a Deus. É o meu primeiro amor, Laura. Na vida só amei tanto a um ente, que já está no céu, - a minha mãe por quem sempre faço orações...

- Sou curiosa: qual o deus desse culto?

- Sei que o conheces tanto, como ao Dr. Cláudio.

- Não, não sei.

- Determinaste arrancar hoje um por um os segredos da minha alma!

- E não sou eu tua amiga?

- Perdoa; bem sei quanto me estimas; mas não posso dizer-te o nome desse moço.

— Por quê? Pois vou adivinhá-lo, é Eugênio, é meu primo...

- Sim, respondeu Madalena com os olhos baixos.

- E ele te ama? perguntou Laura empalidecendo.

- Não sei; pareces um vigário de freguesia!

Laura sofreu tanto abalo, mostrou-se tão impressionada pelo que ouvira de sua amiga, que não passou desapercebida para esta a comoção da prima de Eugênio.

- Mas o que tens, empalideces?

— Nada, um leve incômodo, uma pequena vertigem.

Com efeito se ela não tivesse se assentado logo, teria tido algum desmaio.

- E eu, que vinha dizer-lhe que também o amava! disse Laura mostrando-se pensativa.

- E não me contas nem um só dos teus segredos? Confessa-te também Laura?

- Agora não, necessito de algum descanso. Adeus Madalena.

— Ah, ingrata! E não tencionas ir ao sarau do Dr. Cláudio?

- Talvez.

— Lá então me dirás tudo, que vai pelo teu coração; também sou curiosa, Laura.

Madalena acompanhou a sua amiga até a porta; aí as duas amigas trocaram dous beijos de despedida, retirando-se Laura para a sua casa, a qual ficava à pequena distância da morada de Madalena.

Lembrai-vos do retrato da Haidéa de Monte Cristo? Já vistes uma dessas mulheres belas fantasiadas por Ossian? Vistes já um desses ideais, que Fídias deixou sobre a pedra, Miguel Ângelo sobre a tela e Dante em um poema? Teríeis então a cópia do retrato de Madalena.

Madalena era tão linda, que parecia um desses anjos, que a terra nos apresenta para causar inveja aos arcanjos do céu. 
Tinha os olhos vivos, negros e belos, a boca pequena e mimosa, o nariz afilado, os cabelos negros e crespos, o rosto oval, a tez pálida. Se a vísseis dentro de uma redoma, diríeis que era uma santa!

Retirando-se Laura, Madalena foi sentar-se junto de seu piano, mas começava a tocar um dueto da ópera de Julieta e Romeu, quando bateram no corredor.

Apareceu um moço na sala.

- Sentai-vos, Sr. Eugênio.

- Pouco me demoro. Está aí o vosso pai?

- Creio que não.

- Senhora, disse Eugênio, dirigindo-se à Madalena, não é preciso dizer-vos mais que vos amo, porque meu coração já vos tem dito, já vos tem revelado esse amor. Vós sabeis, que este culto, este amor santo e puro, que vos consagro, enche todo o meu peito, que....

- Senhor!

- Que este amor é o meu sonho, a minha luz, o meu céu... Mas o amor não deve ser rosa, que tenha só espinhos. Até aqui tenho sofrido, porque tenho vivido longe de vós e a separação mata os corações, que se amam. Ah! como deve ficar bela a vossa fronte com uma coroa de noiva!

Madalena corou, as suas faces pareciam duas largas pétalas de rosa.

- No vosso rosto leio a vossa resposta. Obrigado, D. Madalena. E hoje venho saber se vosso pai abençoa a nossa união.

— Ah! hoje não, Sr. Eugênio, esperai.

- Esperar! Dizei a aquele que luta com as ondas, e que vê o céu azul e brilhante, que não se salve, que espere; dizei a aquele que pode atingir a felicidade e a vida, que fique estático, infeliz, que morra, que espere. Dizei a mim que espere, que fique com o meu amor, que sofra! Ah! Senhora, para quem ama esperar é morrer.

- Sossegai, Sr. Eugênio, mas peço-vos que não faleis hoje a meu pai sobre o nosso casamento; daqui a alguns dias...

— E por que não há de ser hoje? Se me amásseis...

- Não me acuseis, Senhor...

— Sem dúvida já esquecestes esse amor que dizíeis, que era santo, que era um pensamento do céu....

- Não, não o esqueci, porque não posso esquecer-me, que tenho coração, porque jurei que vos amaria sempre. Mas hoje veio meu pai falar-me em outro casamento, e se hoje lhe fôsseis dizer, que desejáveis ser o meu esposo, ele poderia julgar isso uma ofensa, uma ingratidão partida de mim, pois sabeis, que ele ignora o nosso amor.

- Ah! já tendes outro noivo! Talvez mais rico e belo. Andastes depressa, senhora! E eu que a julgava simples como uma criança, eu que a amava, como se amasse um anjo!

- Senhor Eugênio, por aquele Cristo que nos ouve, pela natureza, pelo universo vos juro, que só tenho amado a um homem neste mundo. E Madalena chorava como uma criança.

— Mas para que esses juramentos e essas lágrimas! Ah! é assim que vós e outras iludem, disse Eugênio pálido e trêmulo. 
- Adeus, Senhora; sede feliz. Assim como vos dei todo o meu amor, desejava dar-vos agora toda a felicidade. E Eugênio saiu precipitadamente.

- Virgem de Deus, protegei-me.

E Madalena derramando amargo pranto, caiu quase desfalecida sobre uma cadeira.

O moço, que acabara de sair, tinha 25 anos; era alto, de semblante alegre e simpático; testa elevada, olhos pardos, boca pequena, tez clara e corada, e cabelos louros e anelados.

Eugênio era estudante de medicina. Inteligente, de alma pura, de coração limpo, era estimado pelos seus mestres e colegas. Quem o conhecesse poderia dizer, que encontrava nele um amigo.

Eugênio no silêncio e calma do seu gabinete, conheceu bem cedo, que fora ingrato e precipitado, o juízo que fizera de sua amante.

- Sim, dizia ele, ela falou-me de um casamento, que o seu pai lhe propusera, mas sei eu, se ela aceitou esse noivo, que lhe foi apresentado? Chorando não a vi jurar, que me amava; mas essas lágrimas, esses juramentos podem ser fementidos! Ah! Se até os anjos mentem, a verdade é uma quimera, é uma palavra vária do dicionário da humanidade!

- Fui ingrato para com essa moça, porque sei que Madalena me ama, que o seu coração é o santuário do meu amor; fui precipitado porque não atendi às suas palavras e as suas lágrimas. Ah! Fui mau, fui arrebatado. Perdoa, Madalena.

- Mas nem sei o que digo, sinto que o cérebro ferve no meio do sangue, que me enche o coração. Porém Madalena vai hoje a um sarau, lá procurarei observar melhor o seu proceder. Às vezes em um baile se adquire muita instrução, o baile é um livro em fólio, onde todos os namorados escrevem as suas aventuras.

\section{Capítulo II}

\section{O Sarau}

Há homens que apesar de ter chegado a uma idade avançada, ainda se enfeitam e se perfumam como moços de 20 anos. Velhos pelos anos querem mostrar-se moços pelo trajar, pela firmeza de corpo e pelos postiços; tornam-se adamados, e começam a gostar das modas e do espelho, como se fossem moças acostumadas a espartilhos e a bailes.

Ainda quando o velho é elegante, inteligente e espirituoso como o Dr. Cláudio, pode-se tolerar, mas quando é feio, mirrado, ignorante e presumido tornar-se então insuportável, e parece um macaco de botas e casaca.

O Dr. Cláudio era de estatura alta, de corpo elegante, calvo, cabelos brancos, rosto alegre e expansivo.

Tinha por costume dar um sarau no dia aniversário de seu nascimento, e era o sexagésimo baile, que dava por este motivo.

Pela sua profissão, pelo seu gênio alegre e afável sabia o Dr. Cláudio prender o coração de todos, mas tinha o seu fraco, gostava de enfeitar-se como um figurino, e apesar de ter 60 anos, amava as moças bonitas, como se fosse um rapaz, que estivesse na sua primavera; todavia era um velho elegante como Chateaubriand, e ao menos não dançava a valsa, nem tingia os cabelos, como fazem muitos velhos, que se cobrem de postiços, para ocultar as mazelas, e outros defeitos herdados dos anos e das moléstias. 
O Dr. Cláudio residia na rua do Conde.

No dia em que dava o seu festim, mandava iluminar a sua casa como um palácio. Via-se aí um salão espaçoso, ornado com simplicidade e gosto, onde as luzes se mostravam reunidas, como as flores nos vasos de porcelana, que enfeitavam as mesas, esse era o salão das contradanças; junto desse, existia outro, ricamente preparado, destinado à música e à cantoria: desse salão é que se entrava para um elegante aposento chamado o toilette, que é cousa tão necessária em um baile, assim como é preciso o camarim para a atriz, e o bastidor para a cena. Às 8 horas começaram aparecer os convidados. Só nomearemos aqueles que, na narração deste nosso pequeno romance, podem de algum modo interessar o leitor.

Anunciou-se a chegada de D. Juliana e sua filha.

D. Juliana era uma senhora de 50 anos, viúva, e mãe de Laura.

Rosto claro e cor-de-rosa, olhos azuis, cabelos loiros, feições mimosas e delicadas como as de uma menina, corpo delicado e frágil como a hástea da pequena flor que um lança em terra, e 28 anos de idade, eis o retrato da filha de D. Juliana.

Apareceram o Sr. Fiúsa e a Sra. D. Nini.

Quando entrou este par, os convidados, que estavam na sala, começaram a rir e a falar em segredo.

O Sr. Fiúsa era um velho baixo, gordo, feio, repugnante, e impróprio mesmo de aparecer em um salão de baile.

Tinha cara espaçosa, nariz imenso, olhos rasgados, boca sem limites, calva grande, e 55 janeiros trepados no costado!

E a Sr.a D. Nini! Era de uma gordura monumental, só por isso poderia ficar em exposição; olhos pardos, cabelos cor de fogo, nariz à maneira de tromba de elefante, boca como a do seu marido, e a barriga, poder-se-ia dizer a Sra. D. Nini e a sua barriga!

E que língua não tinham o Sr. Fiúsa e a Sra. D. Nini! Falavam de todos, sabiam da vida dos vizinhos, como se fosse história, que andasse nas folhinhas de cada ano! Em casa por detrás de uma vidraça empoeirada, indagavam da vida alheia e bispavam tudo, que se passava pelas casas dos vizinhos; chamavam os criados ou escravos que passavam pela rua, e ficavam tão alegres quando colhiam novidade, como ficam contentes os nossos negociantes quando entra o Paquete trazendo boas notícias sobre o mercado do café.

Nini logo que entrou no salão do baile foi sentar-se ocupando duas cadeiras. O Sr. Fiúsa foi para a janela tomar ar.

Entrou no salão o Sr. Eugênio. Já o conhecemos, é o nosso estudante.

Anunciou-se a chegada de Fernando e de sua filha. Então todos os olhares se voltaram para a porta. Algumas moças morderam os lábios, outras começaram a falar com voz baixa, e todos os moços saudaram a filha de Fernando como a rainha da festa. Um belo vestido branco enfeitado com fitas e rendas, cabelo à Stuart, apresentando de cada lado uma pequena rosa branca, um colar de pérolas ao pescoço, sustentando uma cruz de brilhante, lindos brincos de brilhantes, e belas pulseiras de coral: eis os enfeites dessa formosa mulher que atraíra os olhares e as atenções de todos. Madalena estava tão linda com esse vestuário simples e elegante, que parecia uma dessa ninfas, uma dessas sílfides, que em 
noites de luar aparecem na fantasia dos poetas e dos amantes; dir-se-ia que era um anjo esquecido na terra, ou uma dessas virgens, que aparecem no mundo para ser vistas e adoradas.

Às 9 horas deu-se princípio ao sarau.

Nini e Fiúsa, segundo seu costume, começaram a murmurar de tudo; nada havia sobre que esse par grotesco não lançasse o escárnio e o ridículo!

— Julgais, que aqueles brincos e aquela cruz são de brilhantes? Tudo aquilo é pedra falsa!

- Calai-vos, Nini.

- Já não se usa o penteado à Maria Stuart.

— Lá isso é verdade, disse Fiúsa dirigindo-se de novo para a janela.

Acabada a primeira contradança, começou a conversa. O Dr. Cláudio dançara com Madalena a primeira quadrilha.

- Acabais de dar-me grande honra e prazer, minha senhora.

- E por que Dr.?

- Porque me aceitastes como vosso par nesta primeira quadrilha.

- Ah! fiz apenas o que meu pai me ordenara.

- Mesmo assim vos agradeço. E sei que não queríeis vir a este festim.

- Um leve incômodo me ia privando desse prazer.

- Faltaria então tudo neste baile.

— Não vos entendo, Dr.!

— Em um sarau, não havendo uma beleza, que atraia todas as atenções, não há interesse, não há animação.

- Mas aqui não faltam dessas belezas.

- Faltaria a rainha delas se V. Ex., não viesse.

- É muita bondade, Dr.

- Não, senhora; quando adoro as santas, cumpro um dever.

O par de Eugênio tinha sido Laura.

- Não vedes como conversam, dizia Laura mostrando a Eugênio o Dr. Cláudio e Madalena?

— Sim, e ela está tão alegre!

- É uma namoradeira.

- O que dizeis, minha prima?

- Namora a moços e velhos.

- E qual será o seu noivo?

- Pois não sabeis, que ela ama ao Dr.?

- Quereis escarnecer da pobre moça, prima?

— Não, primo, ela o ama e vai ser a sua noiva.

- Como sabeis?

— Disse-me que o amava, e que seu pai lhe falara em casá-la com o Dr.

- E ela?

— Aceitou; ora, o Dr. Cláudio é rico!... 
— Rico, rico! é verdade: e eu o que sou? um pobre estudante, disse Eugênio, parando no meio da sala com sua prima.

- Mas quereis ficar aí firme como uma sentinela do salão?

- Ah! estava distraído!

- Não vedes? o Dr. lhe está oferecendo uma flor.

— E ela a aceita e guarda no seio. Oh! isto é horrível! Mas quando vos disse, que estava tratado esse casamento?

— Ontem de manhã. E vós a amáveis, primo?

- Não sei; mas não quereis sentar-vos? desejo descansar.

- Estais hoje tão aborrecido, Sr. Eugênio!

- Sinto tanto calor, que preciso respirar um ar melhor.

- Vai, meu namorado infeliz, - disse Laura sorrindo-se!

- Quem vos disse, que eu amava essa mulher?

- Ela mesmo, lançando sobre vós todo o ridículo...

- Ah! será aquela mulher um demônio transformado em anjo? Disse Eugênio, quase em desespero.

— Se é um anjo, dá sempre a beber o cálice da amargura.

E Laura, satisfeita do que acabara de fazer, foi sentar-se no meio de outras moças.

Eugênio sabia que sua prima lhe tinha amor, e suspeitando, que o quisesse intrigar com Madalena, porque já lhe tinha dito que soubera do amor, que ele consagrava a essa moça, não acreditou em tudo o que Laura lhe dissera, mas, retirando-se para um canto do salão, determinou observar melhor a sua amante.

Enquanto se dançava, a Sra. Nini e o Sr. Fiúsa observavam tudo que se passava, e tudo criticavam.

— Vede como a D. Juliana usa o vestido curto, parece uma dançarina do teatro!

- E tem 64 anos!

O Sr. Fiúsa, por sua conta, aumentara 14 anos na idade da Sra. D. Juliana.

- E a filha tem dentes postiços!

- Ora, não creio em tal, Nini.

- E por que não? aquela que ali vedes é moça, e anda de cabeleira.

- E quantas saias traz a D. Madalena?

—É tal e qual! parece o Pão d'Açúcar andando pela sala. E Fiúsa pôs-se a rir às gargalhadas!

Durante todo o sarau, Eugênio não escolheu Madalena, nem uma só vez, para seu par, mas dançou com quase todas as moças, e principalmente com sua prima.

Madalena percebeu que Laura e Eugênio fugiam dela, mas não querendo mostrar-se despeitada, dançou, valsou e cantou; a cada instante recebia um triunfo; admirada e festejada por todos, dir-se-ia que esse festim fora feito só para ela.

Quando começou o serviço do sarau, Nini e Fiúsa começaram desabridamente:

- Ah! gosto mais de um pastel, do que do melhor som de uma rabeca.

— Um sarau sem doces é um anacronismo: não concordais, Fiúsa? 
- Apoiadíssimo, Nini; respondeu Fiúsa meio engasgado com um pedaço de pão-de-ló.

- E como é bom um sorvete!

- Refresca tanto o estômago, que parece que se está na Rússia!

Vendo a gulodice de Nini e Fiúsa, notando o modo porque eles se atiravam às bandejas de doce, dizia Fernando, em voa baixa, passeando com o Dr. Cláudio:

— Estão famintos, comem doces como os hebreus comiam maná!

- E se apresentaram aqui sem ser convidados!

- Para irem amanhã contar à vizinhança o que se passou em vossa casa.

- Sei que são almanaques da vida alheia.

- São uns miseráveis cães, que ladram a todos os que vêm; com a língua profanam e conspurcam tudo, mas eu os desprezo.

E Fernando e o Dr. Cláudio foram se dirigindo para as mesas de jogo.

Continuava o sarau. Nini e Fiúsa não cessavam de comer, e de engasgar-se; Laura persistia em suas intrigas; Eugênio já se mostrava desesperado, Madalena já se ia afligindo com os elogios, que lhe faziam a todos os momentos, o Dr. Cláudio jogava com os seus amigos o solo e o voltarete, quando ouviu-se o sino da igreja de S. Francisco anunciar incêndio.

Chegaram todos à janela e viram, que o incêndio era em uma casa da praça da Constituição. Em breve as labaredas indicaram o lugar do sinistro: a casa que ardia estava colocada na fachada da praça, que fica fronteira à rua do Conde.

- Parece ser na casa do Sr. Fernando, disse Eugênio.

- É certo.

- É lá mesmo, disse Fernando saindo precipitadamente com sua filha.

O Dr. Cláudio, Laura, Juliana, Eugênio e alguns outros amigos os acompanharam.

Nini e Fiúsa deixaram pesarosos as bandejas de doce e iam dizendo, descendo as escadas:

- Vamos lá ver isso, que nos privou dos doces e dos sorvetes: talvez seja algum incêndio insignificante!

\section{Capítulo III \\ Incêndio e Sacrifício}

O incêndio era na casa de Fernando.

O fogo foi tão violento, que em breve apoderou-se de toda casa, espalhando-se por todo o edifício.

Vieram os socorros públicos, mas a violência do incêndio, o tumulto e a confusão que começaram a reinar, tornaram inúteis todos os auxílios.

Fernando e os seus amigos procuravam salvar alguma cousa, mas em vão; a impetuosidade das chamas repelia àqueles que ousavam querer entrar nessa grande fogueira.

Por três vezes Fernando abriu caminho pelo fogo, para ver se podia livrar um pequeno cofre, onde existia uma avultada quantia, que no dia seguinte, tinha ele de levar para uma província por ordem do Governo, porém por três vezes as labaredas do incêndio mataram as forças e as esperanças do pobre empregado público. 
Eugênio, o Dr. Cláudio e outros amigos e vizinhos de Fernando fizeram tudo para ver se podiam tornar menor o prejuízo do seu amigo, mas era tarde, o incêndio tinha devorado o prédio, e restavam apenas quatro paredes destruídas pelo fogo, e enegrecidas pelo fumo.

Fiúsa e Nini nada fizeram. Fiúsa foi colocar-se no meio da praça, e dizia aos que notavam o seu procedimento:

— Nada, o Fiúsa não é salamandra.

Nini quis observar o incêndio mais de perto, e aproximo-se tanto do lugar do sinistro, que algumas telhas e pedras caindo-lhe sobre a cabeça, fizeram-lhe perder os sentidos. Todos foram prontos em socorrê-la, mas foi tão violenta a pancada que a pobre Nini recebeu, que passou logo para a eternidade, sem soltar um só gemido. Fiúsa mostrou-se inconsolável, e começou a derramar lágrimas como um bom marido.

Chorando, exclamava o triste viúvo:

— Ah! Nini, Nini, para que foste tão curiosa! não viste o que fez teu marido, que apartou-se do lugar do sinistro?... Coitada de Nini!

- Sossegue, Sr. Fiúsa, dizia Eugênio.

- Pois não hei de carpir a morte deste anjo, desta santa, que de todas falava bem!

- Que santa!

— É verdade, Sr. Eugênio! Alma cândida e pura, disse Fiúsa olhando para o cadáver de Nini, adeus, e fiques sabendo que eu não desejo ter notícias de cousa alguma, que observares lá pelo outro mundo; adeus Nini.

- Não é o Sr. só que chora, veja como está abatida e pesarosa a filha do Sr. Fernando! E note como ele está desesperado e aflito!

—É assim: a vida é um rio de lágrimas, disse o pobre viúvo, ajoelhando-se e fazendo orações junto ao corpo de sua infeliz mulher.

Fernando mostrava-se acabrunhado com o desastre que lhe acontecera.

Sentia-se tão perturbado, que nem sabia o que deveria fazer, se atender para a sua filha, que estava desfalecida nos braços de suas amigas, ou se deveria dar algumas providências, para tornar menor o prejuízo e a desgraça que caíra sobre ele.

Quando viu a sua casa inteiramente destruída, dizia aflito e comovido:

- Meu Deus, que fatalidade! pobre, miserável, e além disso, talvez condenado a ser lançado em uma prisão!

- O que dizeis, Sr. Fernando? perguntou Eugênio.

- Recebi do governo uma quantia para ser entregue a uma tesouraria da província, amanhã ia cumprir essa missão, porém esse incêndio que devorou o que era meu, fez desaparecer também esse dinheiro: agora vejo-me pobre, sem poder satisfazer o encargo do Estado, assim talvez tenham de abrir-se para mim as portas de uma prisão: oh! que desgraça, meu Deus!

- O que dizeis, meu pai? não, não sereis preso: por ventura depois da desgraça ainda há de vir o martírio? ah! não vos arrancarão dos meus braços, disse Madalena enlaçando seu pai com os seus braços frágeis e trêmulos.

- Coitada, disse Eugênio penalizado. 
Juliana e Laura, arredadas do lugar sinistro, observaram essa cena triste e desastrosa, e apesar de comovidas, não sabiam o que deveriam fazer.

- Tudo está perdido, minha filha! e ela, Deus meu, acrescentou Fernando olhando para o céu, ela que a eduquei com tanto mimo, que viveu sempre cercada de carinhos e afagos, e que tão moça vivia embalada de esperança e felicidade: como ficará sem mim! E tão fraca, tão débil, como poderá trabalhar para poder viver! Ah! é terrível a hora da desgraça!

- Tranqüilizai-vos, meu pai, saberei trabalhar para ajudar-vos; não descansarei, não dormirei enquanto não puder obter o pão do nosso sustento; estou moça, amo o trabalho, amo a atividade e adoro a Deus e a meu pai, mas não me falei mais em prisão! Ah! por alma de minha mãe, vos juro que nunca me hão de separar de vós.

- Nada tendes que recear, disse Eugênio, dirigindo-se a Fernando: se esse dinheiro desapareceu, foi por um acontecimento imprevisto e fatal.

- Fiúsa, que viera colocar-se perto das pessoas que falavam, para ouvir melhor tudo, que diziam, planejou um plano de vingança contra Fernando, e saindo apressado, foi dizendo em voz baixa.

- Agora me vais pagar, impostor, nunca me tiraste o chapéu, vizinho malcriado; escarnecias e falavas de mim, pois agora vou meter-te em calças pardas, e desapareceu.

O Dr. Cláudio observava toda esta cena sem dizer palavra e sem mover-se do lugar em que estava.

De repente viu-se aproximar um oficial seguido de alguns soldados.

- O Sr. Fernando? perguntou o oficial.

- Aqui estou, Sr.

- Tenho ordem de levar-vos preso.

- E por que, $S r$ ?

- Denunciaram que fostes vós que lançastes fogo a esta casa!

- E para que, Sr. Oficial?

- Para apoderar-vos assim de uma quantia que vos fora entregue pelo governo.

$-\mathrm{Ah} !$

—É falso, Sr., é falso, exclamou Madalena apresentando-se diante de sue pai. Acusarem meu pai de incendiário e ladrão! Meu pai, que tem envelhecido no serviço público! Que a única condecoração que traz sobre o peito, é a sua honra. Meu pai incendiário e ladrão... é falso, Sr., é falso. Ah! mas sede indulgente, Sr., continuou Madalena, lançando-se aos pés do oficial; sede humano, não arrebateis um pai dos braços de sua filha; eu vos rogo; é uma filha que vos fala, atendei ao grito da natureza.

- Nada posso fazer, Sra.; devo executar as ordens que me foram dadas.

O Dr. Cláudio aproximando-se do oficial, exclamou:

- Mas por que quereis prender o Sr. Fernando?

— Não posso dar explicações a todos.

— Falastes em uma quantia, que dizem fora subtraída por esse homem; não sei que soma seja essa, mas o que posso afiançar-vos, é que vinte contos que ele recebera do Estado, esse estão em meu poder; o Sr. Fernando entregou-mos para guardar. 
- Ah! disse Fernando olhando para o Dr. Cláudio.

- Foi sobre essa mesma quantia que versou a denúncia; mas se assim é: para que esse senhor não fez logo essa declaração?

- Não vedes como está perturbado e comovido! Homem honrado, que nunca julgara possível o suspeitar-se de sua honra, bastou a vossa presença para o aterrar.

- Irei pois, participar à autoridade competente o resultado desta diligência.

- Amanhã será entregue ao tesouro público aquela quantia. Quereis fiança?

- Não, Sr. Dr., creio na vossa palavra de cavalheiro. E o oficial retirou-se com a força que conduzira.

— Quanto vos agradeço, Sr., por terdes salvado a meu pai, disse Madalena aproximando-se do Dr. Cláudio.

- Ah, meu amigo, livrastes-me de uma vergonha, à qual estou certo, que não resistiria; a minha gratidão é vossa, Dr., e Fernando, cheio de reconhecimento, apertou a mão do Dr. Cláudio.

- Que homem generoso, que amigo sincero! - disse Eugênio alegre pela ação, que Cláudio acabara de praticar.

- Sr. Fernando, satisfeito por ter podido socorrer a um amigo, que tanto prezo, desejava, que este dia ficasse gravado no meu coração por algum outro acontecimento feliz.

- Explicai-vos, Dr.!

O que quererá ele dizer! balbuciou Madalena assustada.

- Sabeis, que amo a vossa filha, e já vos falei em um casamento...

- Dr., disse Fernando interrompendo o velho, desejaria unir o destino de minha filha ao de um amigo tão generoso, ao de um homem tão honrado; mas esse casamento não pode ter lugar; minha filha não o quer, e eu não desejo contrariá-la. Seria mais fácil ir morar em uma prisão, dormir no chão úmido, de um cárcere, comer o pão negro da masmorra, do que sacrificar a sorte de minha filha. Perdoai, Dr., se assim vos falo, mas sabeis, que no mundo só amo a minha Madalena.

- Não é preciso afligir-vos, Sr. Fernando - disse o Doutor encarando Madalena.

A filha de Fernando tendo observado o que se passara entre o Dr. Cláudio e o seu pai, disse com voz fraca e trêmula:

- Meu pai, quando me falastes no meu casamento com o Dr. Cláudio, irrefletidamente vos disse que não; mas hoje que vejo nesse homem o nosso melhor amigo, o nosso anjo de salvação, a vossa filha vem dizer-vos - que deseja ser esposa do Dr. Cláudio.

- O que disse ela!... exclamou Eugênio visivelmente perturbado.

Laura com sua mãe, tinha-se aproximado às pessoas, que falavam, e ouvindo o pedido do Dr. Cláudio, disse sorrindo-se:

- Ah! este velho afetou desinteresse para melhor promover o seu interesse.

- Será o teu coração quem fala, minha filha, disse Fernando abraçando Madalena - ou queres sacrificar-te por mim? Fala, quero que as tuas palavras sejam o eco do teu coração: é por tua vontade, que desejas ser esposa do nosso benfeitor?

- Sim, meu pai, respondeu Madalena olhando para Eugênio e para o céu!

- Dr., a minha filha é vossa noiva. 
- Ah! eu vos agradeço, Sr., disse o Dr. Cláudio aproximando-se de Madalena.

- Eu não vos dizia, primo, disse Laura a Eugênio, que esta moça amava o velho? E ainda quereis namorá-la!

E a filha de D. Juliana, sorrindo-se, tomou o braço de sua mãe e retirou-se.

O Dr. Cláudio acompanhou a Fernando e a sua filha, que também se ausentaram.

- Meu Deus, disse Eugênio, que ficará só: quantos tormentos para um pobre coração de moço! Quantas lágrimas na primavera da vida! Quanto amor desvanecido em um momento! Ver renegado, com uma só palavra, um amor que eu julgara puro, que crera santo, que acreditara imenso. Ela, mulher de outro! De um velho que já olha para a terra, onde se lhe deve abrir a sepultura! Ela tão moça, tão bela! Será por ser ele rico? Mas tanta ambição, tanta baixeza não pode contaminar a uma alma ainda tão virgem! Terá ela se sacrificado por seu pai? Mas para que encarou-me, quando foi pronunciar esse - sim - fatal! Queria matar-me de dor, ou desejaria que eu avaliasse o seu sacrifício? Meu Deus, dai-me forças para poder sofrer todos estes martírios do coração!

\section{Capítulo IV \\ O Anjo da Família}

No dia determinado, o Dr. Cláudio depositou a quantia, pela qual se empenhara. Não recebeu do seu amigo declaração alguma.

Fernando tratou de preparar e dispor tudo para o casamento de sua filha. Fazia-se o enxoval; a modista costurava o vestido do noivado.

Aos amigos já tinha Fernando participado esse casamento, que o enchia de satisfação.

Porém Madalena mostrava-se cada dia mais triste e pálida, mais abatida e acabrunhada. Dirse-ia que essa moça, julgando que não poderia mais viver, ia desfalecendo, porque ia-se aproximando da sepultura.

Quem visse o seu rosto pálido, os seus olhos mergulhados em lágrimas, cercados de uma auréola roxa, sinal de insônia e de martírio, os seus cabelos pretos, soltos pelas costas, como se fossem um véu de luto, os seus lábios desbotados, se entristeceria bastante, e julgaria ver a imagem de dor, bela, porém muito triste! Tanta dor, tanto martírio não apresentara o semblante de Madalena - a Santa, quando enxugara o suor do seu Redentor.

Fernando se afligia, por ver a filha tão triste e melancólica. Beijando e abraçando-a, dizia esse bom pai:

- Por que te mostras tão pesarosa, minha filha? Dize a teu pai a causa de tuas lágrimas, a dor de tua alma!

— Nada tenho, meu pai. Essas lágrimas, esse luto de meu coração, provém de ver-vos tão infeliz e pobre.

- Porém breve vais ser esposa de um homem rico, milionário, e então protegerás o teu pai: não é assim, Madalena?

- Sim, meu pai, sim; mas é se eu puder viver até lá.

- O que disseste! não ouvi bem as tuas palavras, falas em morrer! tu, o meu anjo da terra, o coração de meu corpo, a alma da minha vida: e então o que será do teu pai! Ah! queres morrer, e 
deixar-me no mundo, só, com a minha miséria, com os meus cabelos brancos: e dizes que me amas, Madalena?

- Meu pai!

— Falas em morrer: e por quê? não queres ser noiva do Dr. Cláudio, não desejas que esse casamento se faça, dize e tudo será desfeito; correrei à casa desse meu amigo e lhe direi: "Minha filha não quer ser vossa noiva". Até aqui, Madalena, nunca faltei à minha palavra, mas para fazer-te feliz, para dar-te risos e alegrias, irei ter com o Dr. Cláudio, e lhe farei esquecer tudo o que lhe disse.

- Meu Deus, dai-me forças para poder sustentar o meu próprio coração.

- Sê franca, Madalena; não quero que depois digas: "aquele que podia dar-me felicidade, deu-me desgraça; de meu pai herdei só lágrimas!”

- Quero ser esposa desse homem, meu pai, e perdoai as minhas lágrimas; choro porque sou uma criança. Ficarei alegre só por vos ver contente.

- Sim, minha filha, porque dos teus risos nascem as minhas alegrias. - E Fernando se retirou, depois de ter beijado a sua filha.

- Complete-se o sacrifício, disse Madalena; rir-me-ei quando desejaria chorar: não vou também cingir a grinalda do noivado, quando quereria antes a capela da morte?

Tendo-se incendiado o prédio de Fernando, alugou este uma pequena casa na rua de S. Clemente.

Essa casinha tinha um jardim ao lado: aí olhando para as flores e para as borboletas que voavam, passava Madalena as suas tardes, que eram bem tristes. Em uma tarde estava ela tão pensativa e absorta, que não viu entrar no jardim um moço vestido de preto, o qual se foi colocar diante dela como se fosse um fantasma, que quisesse namorar a filha da dor. Esse moço apresentava os olhos encovados, as faces deprimidas, os cabelos caídos pela testa como os do lavrador depois do trabalho do dia; o seu semblante bastante pálido era de um aspecto feio e triste, pungente e terrível.

Parecia a imagem de Cristo no jardim retratada pelo pintor Rembrandt.

O moço deu um passo para onde estava Madalena; as folhas secas, que se quebraram com as suas pisadas, despertaram a filha de Fernando, que deu um grito e quis fugir.

- Esperai...

- Senhor...

— Escutai, Madalena; um amor excessivo e ardente, como uma onde de fogo, me impeliu até vós. Se não fora esse amor, que vos consagro, imenso como a extensão, se não fora esse amor, hino contínuo do meu coração, única consolação de minha alma, eu não viria até aqui; morreria sem vervos Madalena. Foi essa paixão, que me impeliu até vós, para perguntar-vos o que fizestes desse amor, que me tínheis, desse amor simples, como a primeira palavra, belo como o céu, vivo e ardente como o sol!

- Atendei-me, Sr. Eugênio, e não penseis, que reneguei esse amor santo e puro que o meu coração vos tinha dado; não julgueis perjura aquela, que apenas é mártir.

- Meu pai me propusera o casamento com o Dr. Cláudio; recusei esse noivo; nessa mesma ocasião vos apresentaste para obterdes a minha mão; vos pedi então que não désseis esse passo, não só porque nesse mesmo dia recusaria eu o noivo que meu pai me propusera, como também ainda não 
lhe tinha dito o amor que o meu coração vos devotava; mas o ciúme, Sr. Eugênio, vos tornou então injusto e mau!

- Perdoai, Madalena!

- Soubestes depois da desgraça que caiu sobre o meu pai; vistes que o Dr. Cláudio o livrara de uma prisão infame e vergonhosa, porém que ao mesmo tempo pedira a mão da filha do seu amigo!

- E então o que deveria eu fazer, Sr. Eugênio? Recusando o casamento com o Dr. Cláudio, não poderia ele negar-se a fazer o que prometera, e meu pai não poderia ser preso e morrer? Quis pois sacrificar-me por meu pai; não julgueis assim uma leviandade o que é um sacrifício, uma ingratidão o que é um dever.

— Então ainda me amais, Madalena?

- Duvidais, Sr. Eugênio? Só deixarei de amar-vos, quando a minha alma desprendida do corpo tiver ido ao céu, quando o meu coração, vazio de sangue, se tiver enchido de gelo.

- Ah, dizei-o, repeti mil vezes. Obrigado, Madalena. E agora vos juro pela terra e pelo céu que esse casamento não se fará. E Eugênio saiu precipitadamente. Madalena quis detê-lo, mas foi impossível.

- O que irá ele fazer, meu Deus! E a infeliz moça retirando-se para o seu quarto se foi ajoelhar diante de Deus crucificado. Eugênio dirigiu-se à casa do Dr. Cláudio.

Cláudio preparava-se para o seu noivado. O velho estava contentíssimo, ia casa-se com uma mulher moça, bela e elegante. Nem todos na sua idade encontram igual felicidade. Anunciada a chegada do estudante, o médico apresentou-se logo.

- Doutor, disse-lhe Eugênio, trêmulo e pálido, sei que breve vai ter lugar o vosso casamento com a filha do Sr. Fernando...

- Estou certo, que haveis de julgar, que não é uma novidade para mim o que me viestes dizer, senhor...

- Mas talvez seja o dizer-vos, que essa moça ama apaixonadamente a outro homem...

- A quem, Sr. Eugênio?

- A um moço infeliz e pobre, e que tem por essa mulher uma paixão louca e veemente; a um moço que tem sofrido tanto pelo seu amor, que as lágrimas já lhe fogem dos olhos e o sangue do coração.

- Admiro o que me acabais de dizer; essa moça declarou, que aceitava a minha mão.

- As suas palavras o disseram, mas não poderia dizer o seu coração.

E Eugênio relatou ao Dr. Cláudio tudo que Madalena lhe dissera.

Quando o pobre moço acabou de falar, estava cansado e abatido.

— E então, Doutor, continuou Eugênio: ainda desejais fazer esse casamento? quereríeis por ventura matar dous corações, e preparar o túmulo para duas vítimas?

- Comoveu-me o que me dissestes, Sr. Eugênio. Admiro o sacrifício do coração dessa moça. Peço-vos que, amanhã, a esta mesma hora, volteis de novo a esta vossa casa.

- Esperar ainda tanto tempo!

- Sei que esperar 24 horas é muito para quem ama, mas não para quem deseja refletir.

- Até amanhã, Doutor, disse Eugênio, despedindo-se do velho Cláudio. 
Os leitores desejarão saber o que foi feito do Sr. Fiúsa. Vendo que fora frustrada a sua denúncia contra Fernando, e perseguido por este e por aqueles, aos quais a sua língua viperina não cessava de atassalhar, Fiúsa, esse Aretino prosaico e barrigudo, retirou-se para uma vila de província, e arvorouse em procurador; mas querendo sonegar uns autos, foi recolhido à prisão, e lá ficou bispando das grades do cárcere o que se passava pelo mundo. Deus o conserve preso e calado.

Eugênio visitava sempre a sua prima; a mãe de Laura era a sua segunda mãe e havia-o amamentado; assim tinha ele razão para amar a sua colaça e a D. Juliana. Antes de ir ter com o Dr. Cláudio, passou pela casa de sua prima:

- Ides agora à casa do doutor, primo?

- Sim, respondeu Eugênio pensativo.

- Cuidado, acautelai-vos.

- E por que?

- Prepara-se uma traição contra vós.

- Quem vos disse?

- Um criado do doutor.

- Será possível!

- Sim, trata-se mesmo de um crime.

- Não posso crer: o doutor é homem honrado; deu-me ontem provas da bondade de seu coração.

- Talvez fosse melhor chamá-lo de hipócrita.

— Duvidais de todos, prima!

- Peço-vos para não irdes à casa desse homem.

- Então o que se prepara contra mim?

- O Dr. Cláudio já está casado, e se fordes hoje à casa dele, talvez pagueis com a vida a pertinácia do vosso amor.

— Oh! meu Deus, será possível! Não, agora é que desejo lá ir; quero vingar-me! - E Eugênio saiu apressadamente.

- Perdi a minha última tentativa, disse Laura!... o temor não o deteve; pois bem, procurarei esquecer com outros amores este amor infeliz e perdido.

Eugênio ocultando uma pistola no bolso de sua casaca, apresentou-se, à hora marcada, na casa do Dr. Cláudio. Quando entrou, viu o doutor sentado entre Madalena e Fernando. Madalena ficou tão perturbada e pálida, que quase desfaleceu.

Eugênio levou repentinamente a mão ao bolso da casaca e abraçou com mão trêmula a coronha da pistola.

- Sentai-vos, Sr. Eugênio, disse Cláudio.

O moço obedeceu maquinalmente.

- Sr. Fernando, disse Cláudio, participo-vos que o meu casamento com vossa filha não pode ter lugar.

- O que ouço, balbuciou Eugênio!

- E por que, doutor? agora que este casamento já está divulgado! agora... 
— Vossa filha se casará.

- Explicai-vos, doutor!

- Madalena tremia; Eugênio estava surpreendido.

— O seu noivo há de ser este moço, e Cláudio apontou para Eugênio.

- O que dizeis, doutor?

Madalena deu um grito de espanto; Eugênio quis sair do lugar em que estava para ir abraçar o Dr. Cláudio.

- Sim, meu amigo, por vós queria a vossa filha sacrificar-se. Só por temer as desgraças que vos poderiam sobrevir, abafara no seu coração um amor veemente, uma paixão bela, como o seu coração de vinte anos, e ia ligar-se a um homem velho, julgando que assim livraria seu pai de tormentos e de dores. Ah! comoveu-me o sacrifício que essa moça queria fazer do seu amor e talvez de sua vida!

- Minha filha! - exclamou Fernando abraçando Madalena.

- Determinei então, continuou o Dr. Cláudio, abandonar a felicidade de ser esposo de uma mulher tão bela e virtuosa para não ser a causa do martírio e da morte de um anjo. O seu noivo deve ser este moço, que a ama, que a adora...

- Ah! eu enlouqueço, exclamou Eugênio apertando convulsivamente a cabeça com as mãos. Obrigado, doutor; destes-me mais que a vida, destes-me a felicidade!

Madalena, trêmula e chorosa, disse ao Dr. Cláudio:

- Meu Deus, será isto um sonho! sereis algum anjo vindo do céu, que me fales de amor e felicidade!

- Sou a imagem da Providência, que vem trazer o prêmio do vosso sacrifício. Do alto dos céus Deus sabe coroar a virtude da terra. E nem vós, nem este moço tendes que agradecer-me. Eu rejeitaria a felicidade do céu, se para obtê-la fosse preciso cometer uma ação má. Se sabendo do vosso amor e do vosso sacrifício persistisse em querer ser vosso esposo, julgaria um remorso a felicidade, a ventura, que roubaria assim do coração de dous entes. Não tendes que agradecer-me; foi a admiração pelo vosso sacrifício, pela vossa virtude, que guiou os passos do homem velho e honrado.

- Mas eu, disse Fernando, devo agradecer-vos, abraçar-vos e apertar a vossa mão de amigo sincero e de homem honrado. Se o sacrifício de minha filha mostra o amor que ela me consagra; o que acabais de fazer patenteia o vosso coração generoso. Ah! custa a encontrar uma alma e um coração generoso como o vosso, doutor!

- E uma filha como Madalena.

- Admiro tanto, disse Eugênio, a virtude de Madalena, como a honra do Dr. Cláudio!

- Meus filhos, disse Fernando dirigindo-se a Eugênio e a Madalena, Deus abençoe a união que se vai formar entre vós, e peço-vos que nunca esqueçais do Dr. Cláudio, do nosso protetor, desse homem que salvou-me da prisão e da ignomínia, que vos trocou, Madalena, as lágrimas pelos risos, o martírio pela ventura!

- Deus vos proteja e abençoe - disse o Dr. Cláudio.

— Sim, exclamaram Madalena e Eugênio, jamais nos esqueceremos do anjo da nossa família.

Um mês depois do que acabamos de relatar; celebrava-se o casamento de Madalena com Eugênio. 
O Dr. Cláudio continuou a ser protetor desta família.

A bondade de certos homens é inesgotável: eles assemelham-se a esses rios, que levam sempre fertilidade e vida aqueles lugares onde lançam as suas águas.

E Laura?

Apesar de suas intrigas, não pode a filha de Juliana atrair o coração de Eugênio. O estudante foi constante no seu amor. O amor é um fogo sagrado, que não se aparta do coração que escolheu; é um raio de luz que pode chegar ao céu sem ser desviado pelos ventos da atmosfera. Por fim, Laura cansou; julgou que deveria buscar outro ponto de atração, que deveria gravitar em roda de outro astro: desprezou Eugênio, chamou-o de tolo, talvez, e abraçando-se com seu espelho, procurou enfeitar-se para ver se encontrava um noivo.

Mas foi isso o que não achou, e aí ficou solteira com os seus trinta anos!

A mulher loureira não casa: - é pena, mas não é injustiça.

Fim

\section{O Conservatório Dramático}

A literatura dramática tem, como todo o povo constituído, um corpo policial, que lhe serve de censura e corretivo; é o Conservatório.

Dous são, ou devem ser, os fins desta instituição; o moral e o intelectual. Preenche o primeiro na correção das feições menos decentes das concepções dramáticas; atinge ao segundo analisando e decidindo sobre o mérito literário - dessas mesmas concepções.

Como estes alvos um Conservatório dramático é mais que útil, é necessário. A crítica oficial, tribunal sem apelação, garantido pelo governo, sustentada pela opinião pública, é a mais fecunda das críticas, quando pautada pela razão, e despida das estratégias surdas.

Todas as tentativas, pois, toda a idéia, para nulificar uma instituição como esta, é nulificar o teatro, é tirar-lhe a feição civilizadora, que porventura lhe assiste.

Corresponderá à definição que aqui damos desse tribunal de censura, à instituição que temos aí chamada - Conservatório dramático? Se não corresponde: onde está a causa desse divórcio entre a idéia e o corpo?

Dando à primeira pergunta uma negativa, vejamos onde existe essa causa. É evidente que na base, na constituição interna, na lei de organização. As atribuições do Conservatório limitam-se a apontar os pontos descarnados do corpo que a decência manda cobrir, risca as ofensas feitas às leis do país, e à religião... do Estado: mais nada.

Assim preenche o primeiro fim a que se propõe uma corporação dessa ordem; mas o segundo? nem uma concessão, nem um direito.

Organizado desta maneira era inútil reunir os homens da literatura nesse tribunal; um grupo de vestais bastava. 
Não sei que razão se pode alegar em defesa da organização atual do nosso Conservatório. Viciado na primitiva, não tem ainda hoje uma fórmula e um fim mais razoável com as aspirações e com o senso-comum.

Preenchendo o primeiro dos dous alvos, a que deve tender, o Conservatório em vez de se constituir um corpo deliberativo, torna-se uma simples máquina, instrumento comum, mão sem ação, que traça os seus juízos sobre as linhas implacáveis de um estatuto, que lhe serve de norma.

Julgar de uma composição pelo que toca às ofensas feitas à moral, às leis, e à religião, não é discutir-lhe o mérito puramente literário, no pensamento criador, na construção cênica, no desenho dos caracteres, na disposição das figuras, no jogo da língua.

Na segunda hipótese há mister de conhecimentos mais amplos, e conhecimentos tais, que possam legitimar uma magistratura intelectual. Na primeira, como disse, bastam apenas meia dúzia de vestais e duas ou três devotas. Estava preenchido o fim.

Julgar do valor literário de uma composição, é exercer uma função civilizadora, ao mesmo tempo que praticar um direito do espírito; é tomar um caráter menos vassalo, e de mais iniciativa e deliberação.

Contudo, por vezes as inteligências do nosso Conservatório, como que sacodem esse freio que lhes serve de lei, e entram no exercício desse direito, que se lhes nega; não deliberam, é verdade, mas protestam. A estátua lá vai tomar vida nas mãos de Prometeu, mas a inferioridade do mármore fica assinalada com a autópsia do escopro.

Mas ganha a literatura, ganha a arte com essas análises da sombra? Ganha, quando muito, o arquivo. A análise das concepções, o estudo das prosódias, vão morrer, ou pelo menos dormir no pó das estantes.

Não é esta a missão de um Conservatório dramático. Antes negar a inteligência, que a limita ao estudo enfadonho das indecências, e marcar-lhe as inspirações pelos artigos de uma lei viciosa.

Trocam-se os papéis. A instituição perde o direito de juiz e desce na razão da ascendência do teatro.

E - note-se bem! - é esta uma questão de grande alcance! Qual é a influência de um Conservatório organizado dessa forma? E que respeito pode inspirar assim ao teatro?

Façam ampliar as atribuições desse Corpo, procurem dar-lhe outro caráter mais sério, outros direitos mais iniciadores; façam dessa sacristia de Igreja um tribunal de censura.

Completem, porém, toda essa mudança de forma. Qual é o resultado do anônimo? Se o Conservatório é um júri deliberativo, deve ser inteligente: e por que não há de a inteligência assinar os seus juízos? Em matéria de arte eu não conheço suscetibilidades, nem interesses. Emancipem o espírito, que hão de respeitar-lhe as decisões.

Será fácil uma emancipação do espírito neste caso? - É. Basta que os governos compreendam um dia esta verdade de que o teatro não é uma simples instituição de recreio, mas um corpo de iniciativa nacional e humana.

Ora, os governos que têm descido o olhar e a mão a tanta cousa fútil, não repararam ainda nesta nesga de força social, apeada de sua ação, arredada de seu caminho por caprichos mal-entendidos, que a fortuna colocou por fatalidade à sombra da lei. 
Criaram um Conservatório Dramático por instinto de imitação, criaram uma cousa a que tiveram a delicadeza ou mau gosto de chamar teatro normal, e dormiram descansados, como se tivessem levantado uma pirâmide no Egito.

Ora, todos nós sabemos o que é esse Conservatório e este teatro normal; todos nós temos assistido às agonias de um e aos desvarios do outro; todos temos visto como essas duas instituições destinadas a caminharem de acordo na rota da arte, divorciaram-se de alvo e de estrada. O Conservatório comprometeu a dignidade do seu papel, ou antes o obrigaram a isso, e o teatro, acordando um dia com instintos de César, tentou conquistar todo o mundo da arte, e entreviu também que lhe cumpria começar a empresa por um tribunal de censura.

Com esta guerra civil no mundo dramático, limitadas as decisões de censura, está claro, e claro a olhos nus, que a arte sofria e com ela a massa popular, as platéias. A censura estava obrigada a suicidar-se de um direito e subscrever as frioleiras mais insensatas que o teatro entendesse qualificar de composição dramática.

Este estado de cousas que eu percebo, inteligência mínima como sou, será percebido também pelos governos? Não é fácil de aceitar a hipótese negativa, porquanto evidentemente não os posso considerar abaixo de mim na óptica do espírito. Concordo, pois, que os governo não têm sido estranhos nesta anarquia da arte, e então uma negligência assim, depõe muito contra a consciência do poder.

Não há fugir daqui. Onde está esse projeto sobre a literatura dramática apresentado há tempos na câmara temporária? Era matéria de contrabando, e as aspirações políticas estavam ocupadas em negócios que visavam outros alvos mais sólidos ou pelo menos mais reais. Esse projeto, dando um caráter mais sério ao teatro, abria as suas portas às inteligências dramáticas por meio de um incentivo honroso. Trazia em si um princípio de vida: lá foi para o barbante do esquecimento!

É simples, e não carece de larga observação: os governos em matéria de arte e literatura olham muito de alto; não tomam o trabalho de descer à análise para dar a mão ao que o merece.

Entretanto, o que se pede não é uma vigilância exclusiva; ninguém pretende do poder emprego absoluto dos seus sentidos e faculdades. Nesta questão sobretudo é fácil o remédio; basta uma reforma pronta, inteiriça, radical, e o Conservatório dramático entrará na esfera dos deveres e direitos que fazem completar o pensamento de sua criação.

Com o direito de reprovar e proibir por incapacidade intelectual, com a viseira levantada no espírito da abolição do anônimo, o Conservatório, como disse acima, deixa de ser uma sacristia de igreja para ser um tribunal de censura.

E sabem o que seria então esse tribunal? uma muralha de inteligências às irrupções intempestivas que o capricho quisesse fazer no mundo da arte, às bacanais indecentes e parvas que ofendessem a dignidade do tablado, porque infelizmente é fato líquido, há lá também uma dignidade.

O Conservatório seria isso e estaria nas linhas do seu dever e de seu direito.

Mas no meio destes reparos, resta ainda um fato importante - a literatura dramática.

Com uma reforma no Conservatório, parece-me claro que ganhava também a arte escrita. Não temos (ninguém será tão ingênuo que confesse esse absurdo) não temos literatura dramática, na 
extensão da frase; algumas estrelas não fazem uma constelação: são lembranças deixadas no tablado por distração, palavras soltas, aromas queimados, despidos de todo o caráter sacerdotal.

Não podia o Conservatório tomar um encargo no sentido de fazer desenvolver o elemento dramático na literatura? As vantagens são evidentes - além de emancipar o teatro, não expunha as platéias aos barbarismos das traduções de fancaria que compõem uma larga parte dos nossos repertórios.

Mas, entendam bem! inculco esse encargo ao Conservatório, mas a um Conservatório que eu imagino, que além de possuir os direitos conferidos por uma reforma, deve possuir esses direitos de capacidade, conferidos pela inteligência e pelos conhecimentos.

Não é ofender com isto as inteligências legítimas do atual Conservatório. Eu não nego o sol; o que nego, ou pelo menos o que condeno em consciência são as sombras, as sombras que não dão luz e que mareiam a luz.

Um Conservatório ilustrado em absoluto, é uma garantia para o teatro, para a platéia e para a literatura.

Para fazê-lo assim, basta que o poder faça descer essa reforma tão desejada.

Machado de Assis

\title{
Hoje Avental, Amanhã Luva
}

Comédia em um ato imitada do francês por Machado de Assis

\author{
Personagens \\ DuRval | Bento
}

RosINHA

Rio de Janeiro - Carnaval de 1859

Sala elegante. Piano, canapé, cadeiras, uma jarra de flores em uma mesa à direita. Portas laterais no fundo.

\section{Cena I}

Rosinha (adormecida no canapé);

DURVAL (entrando pela porta do fundo)

Onde está a Sra. Sofia de Melo?... Não vejo ninguém. Depois de dous anos, como venho encontrar estes sítios! Quem sabe se em vez da palavra dos cumprimentos, deverei trazer a palavra dos epitáfios! Como tem crescido isto em opulência!... mas... (vendo Rosinha) Oh! cá está a criadinha. Dorme!... excelente passatempo... Será adepta de Epicuro? Vejamos se a acordo... (dá-lhe um beijo) 
Ros. (acordando) - Ah! que é isto? (levanta-se) O Sr. Durval? Há dous anos que tinha desaparecido... Não o esperava.

Durv. - Sim, sou eu, minha menina. Tua ama?

Ros. - Está ainda no quarto. Vou dizer-lhe que V. S. está cá. (vai para entrar) Mas, espere; diga-me uma cousa.

Durv. - Duas, minha pequena. Estou à tua disposição. (à parte) Não é má cousinha!

Ros. - Diga-me. V. S. levou dous anos sem aqui pôr os pés: por que diabo volta agora sem mais nem menos?

Durv. - (tirando o sobretudo que deita sobre o canapé) És curiosa. Pois sabe que venho para... para mostrar a Sofia que estou ainda o mesmo.

Ros. - Está o mesmo? moralmente, não?

DuRv. - É boa! Tenho então alguma ruga que indique decadência física?

Ros. - Do físico... não há nada que dizer.

Durv. - Pois do moral estou também no mesmo. Cresce com os anos o meu amor; e o amor é como o vinho do porto: quanto mais velho, melhor. Mas tu! Tens mudado muito, mas como mudam as flores em botão: ficando mais bela.

Ros. - Sempre amável, Sr. Durval.

Durv. - Costume da mocidade. (quer dar-lhe um beijo)

Ros. - (fugindo e com severidade) Sr. Durval!...

DURV. - E então! foges agora! Em outro tempo não eras difícil nas tuas beijocas. Ora vamos! não tens uma amabilidade para este camarada que de tão longe volta!

Ros. - Não quero graças. Agora é outro cantar! Há dous anos eu era uma tola inexperiente... mas hoje!

Durv. - Está bem. Mas...

Ros. - Tenciona ficar aqui no Rio?

Durv. - (sentando-se) Como o Corcovado, enraizado como ele. Já me doíam saudades desta boa cidade. A roça, não há cousa pior! Passei lá dous anos bem insípidos - em uma vida uniforme e matemática como um ponteiro de relógio: jogava gamão, colhia café e plantava batatas. Nem teatro lírico, nem rua do Ouvidor, nem Petalógica! Solidão e mais nada. Mas, viva o amor! Um dia concebi o projeto de me safar e aqui estou. Sou agora a borboleta, deixei a crisálida, e aqui me vou em busca de vergéis. (tenta um novo beijo)

Ros. - (fugindo) Não teme queimar as asas?

Durv. - Em que fogo? Ah! nos olhos de Sofia! Está mudada também?

Ros. - Sou suspeita. Com seus próprios olhos o verá.

Durv. - Era elegante e bela há bons dous anos. Sê-lo-á ainda? Não será? Dilema de Hamleto. E como gostava de flores! Lembras-te? aceitava-mas sempre não sei se por mim, se pelas flores; mas é de crer que fosse por mim.

Ros. - Ela gostava tanto de flores!

Durv. - Obrigado. Dize-me cá. Por que diabo sendo uma criada, tiveste sempre tanto espírito e mesmo... 
Ros. - Não sabe? eu lhe digo. Em Lisboa, donde viemos para aqui, fomos condiscípulas: estudamos no mesmo colégio, e comemos à mesma mesa. Mas, cousas do mundo!... Ela tornou-se ama e eu criada! É verdade que me trata com distinção, e conversamos às vezes em altas cousas.

Durv. - Ah! é isso? foram condiscípulas. (levanta-se) E conversam agora em altas cousas!... Pois eisme aqui para conversar também; faremos um trio admirável.

Ros. - Vou participar-lhe a sua chegada.

DuRv. - Sim, vai, vai. Mas olha cá, uma palavra.

Ros. - Uma só, entende?

DuRv. - Dás-me um beijo?

Ros. - Bem vê que são três palavras. (entra à direita)

\section{Cena II}

Durval e Bento

DuRv. - Bravo! a pequena não é tola... tem mesmo muito espírito! Eu gosto dela, gosto! mas é preciso dar-me ao respeito. (vai ao fundo e chama) Bento! (descendo) Ora depois de dous anos como virei encontrar isto? Sofia terá por mim a mesma queda? É isso o que vou sondar. É provável que nada perdesse dos antigos sentimentos. Oh! decerto! Vou começar por levá-la ao baile mascarado; há de aceitar, não pode deixar de aceitar! Então, Bento! mariola?

Bent. - (entrando com um jornal) Pronto.

DuRv. - Ainda agora! Tens um péssimo defeito para boleeiro, é não ouvir.

Bent. - Eu estava embebido com a interessante leitura do Jornal do Commercio: ei-lo. Muito mudadas estão estas cousas por aqui! Não faz uma idéia! E a política? Esperam-se cousas terríveis do parlamento.

DuRv. - Não me masses, mariola! Vai abaixo ao carro e traz uma caixa de papelão que lá está... Anda!

BENTo - Sim, senhor; mas admira-me que V. S. não preste atenção ao estado das cousas.

Durv. - Mas que tens tu com isso, tratante?

Bent. - Eu nada; mas creio que...

DuRv. - Salta lá para o carro, e traz a caixa depressa!

\section{Cena III}

\section{DURVAl e Rosinha}

Durv. - Pedaço d'asno! Sempre a ler jornais; sempre a tagarelar sobre aquilo que menos the deve importar! (vendo Rosinha) Ah!... és tu? Então ela... (levanta-se)

Ros. - Está na outra sala à sua espera.

DuRv. - Bem, aí vou. (vai entrar e volta) Ah! recebe a caixa de papelão que trouxer meu boleeiro.

Ros. - Sim, senhor.

Durv. - Com cuidado, meu colibri!

Ros. - Galante nome! não será em seu coração que farei o meu ninho.

DuRv. - (à parte) Ah! é bem engraçada a rapariga! (vai-se) 


\section{Cena IV}

Rosinha, depois Bento

Ros. - Muito bem, Sr. Durval. Então voltou ainda? É a hora de minha vingança. Há dous anos, tola como eu era, quiseste seduzir-me, perder-me, como a muitas outras! E como? mandando-me dinheiro... dinheiro! - Media as infâmias pela posição. Assentava de... Oh! mas deixa estar! vais pagar tudo... Gosto de ver essa gente que não enxerga sentimento nas pessoas de condição baixa... como se quem traz um avental, não pode também calçar uma luva!

Bent. - (traz uma caixa de papelão) Aqui está a caixa em questão... (põe a caixa sobre uma cadeira) Ora, viva! Esta caixa é de meu amo.

Ros. - Deixe-a ficar.

BENT. - (tirando o jornal do bolso) Fica entregue, não? Ora bem! Vou continuar a minha interessante leitura... Estou na gazetilha - Estou pasmado de ver como vão as cousas por aqui! - Vão a pior. Esta folha põe-me ao fato de grandes novidades.

Ros. - (sentando-se de costas para ele) Muito velhas para mim.

BENT. - (com desdém) Muito velhas? concedo. Cá para mim têm toda a frescura da véspera.

Ros. - (consigo) Quererá ficar?

BEnT. - (sentando-se do outro lado) Ainda uma vista d'olhos! (abre o jornal)

Ros. - E então não se assentou?

Bent. - (lendo) Ainda um caso: "Ontem à noite desapareceu uma nédia e numerosa criação de aves domésticas. Não se pôde descobrir os ladrões, porque, desgraçadamente havia uma patrulha a dous passos dali”.

Ros. - (levantando-se) Ora, que aborrecimento!

BENT. - (continuando) "Não é o primeiro caso que se dá nesta casa da rua dos Inválidos." (consigo)

Como vai isto, meu Deus!

Ros. - (abrindo a caixa) Que belo dominó!

BENT. - (indo a ela) Não mexa! Creio que é para ir ao baile mascarado hoje...

Ros. - Ah!... (silêncio) Um baile... hei de ir também!

Bent. - Aonde? ao baile? Ora esta!

Ros. - E por que não?

BENT. - Pode ser; contudo, quer vás, quer não vás, deixa-me ir acabar a minha leitura naquela sala de espera.

Ros. - Não... tenho uma cousa a tratar contigo.

Bent. - (lisonjeado) Comigo, minha bela!

Ros. - Queres servir-me em uma cousa?

Bent. - (severo) Eu cá só sirvo ao Sr. Durval, e é na boléia!

Ros. - Pois hás de me servir. Não és então um rapaz como os outros boleeiros, amável e serviçal...

BENT. - Vá feito... não deixo de ser amável; é mesmo o meu capítulo de predileção.

Ros. - Pois escuta. Vais fazer um papel, um bonito papel.

BENT. - Não entendo desse fabrico. Se quiser algumas lições sobre a maneira de dar uma volta, sobre o governo das rédeas em um trote largo, ou cousa cá do meu ofício, pronto me encontra. 
Ros. - (que tem ido buscar o ramalhete no jarro) Olha cá: sabes o que é isto?

BENT. - São flores.

Ros. - É o ramalhete diário de um fidalgo espanhol que viaja incógnito.

BENT. - Ah! (toma o ramalhete)

Ros. - (indo a uma gaveta buscar um papel) O Sr. Durval conhece a tua letra?

BENT. - Conhece apenas uma. Eu tenho diversos modos de escrever.

Ros. - Pois bem; copia isto. (dá-lhe o papel) Com letra que ele não conheça.

BENT. - Mas o que é isto?

Ros. - Ora, que te importa? És uma simples máquina. Sabes tu o que vais fazer quando teu amo te indica urna direção ao carro? Estamos aqui no mesmo caso.

Bent. - Fala como um livro! Aqui vai. (escreve)

Ros. - Que amontoado de garatujas!...

Bent. - Cheira a diplomata. Devo assinar?

Ros. - Que se não entenda.

BENT. - Como um perfeito fidalgo. (escreve)

Ros. - Subscritada para mim. À Sra. Rosinha. (Bento escreve) Põe agora este bilhete nesse e leva.

Voltarás a propósito. Tens também muitas vozes?

BENT. - Vário de fala, como de letra.

Ros. - Imitarás o sotaque espanhol?

BENT. - Como quem bebe um copo d'água!

Ros. - Silêncio! Ali está o Sr. Durval.

\section{Cena V}

Rosinha, Bento, Durval

Durv. - (a Bento) Trouxeste a caixa, palerma?

BENT. - (escondendo atrás das costas o ramalhete) Sim, senhor.

DuRv. - Traz a carruagem para o portão.

BENT. - Sim senhor. (Durval vai vestir o sobretudo, mirando-se ao espelho) O jornal? onde pus eu o jornal? (sentindo-no no bolso) Ah!...

Ros. - (baixo a Bento) Não passes na sala de espera. (Bento sai)

\section{Cena VI \\ Durval, Rosinha}

Durv. - Adeus, Rosinha, é preciso que eu me retire.

Ros. - (à parte) Pois não!

Durv. - Dá essa caixa a tua ama.

Ros. - Vai sempre ao baile com ela?

Durv. - Ao baile? Então abriste a caixa?

Ros. - Não vale a pena falar nisso. Já sei, já sei que foi recebido de braços abertos.

Durv. - Exatamente. Era a ovelha que voltava ao aprisco depois de dous anos de apartamento. 
Ros. - Já vê que andar longe não é mau. A volta é sempre um triunfo. Use, abuse mesmo da receita. Mas então sempre vai ao baile?

Durv. - Nada sei de positivo. As mulheres são como os logogrifos. O espírito se perde no meio daquelas combinações...

Ros. - Fastidiosas, seja franco.

Durv. - É um aleive: não é esse o meu pensamento. Contudo devo, parece-me dever crer, que ela irá.

Como me alegra, e me entusiasma esta preferência que me dá a bela Sofia!

Ros. - Preferência? Há engano: preferir supõe escolha, supõe concorrência...

DuRv. - E então?

Ros. - E então, se ela vai ao baile é unicamente pelos seus bonitos olhos, se não fora V. S., ela não ia.

DuRv. - Como é isso?

Ros. - (indo ao espelho) Mire-se neste espelho.

Durv. - Aqui me tens.

Ros. - O que vê nele?

Durv. - Boa pergunta! Vejo-me a mim próprio.

Ros. - Pois bem. Está vendo toda a corte da Sra. Sofia, todos os seus adoradores.

Durv. - Todos! Não é possível. Há dous anos a bela senhora era a flor bafejada por uma legião de zéfiros... Não é possível.

Ros. - Parece-me criança! Algum dia os zéfiros foram estacionários? Os zéfiros passam e mais nada. É o símbolo do amor moderno.

Durv. - E a flor fica no hastil. Mas as flores duram uma manhã apenas. (severo) Quererás tu dizer que Sofia passou a manhã das flores?

Ros. - Ora, isso é loucura. Eu disse isto?

Durv. - (pondo a bengala junto ao piano) Parece-me entretanto...

Ros. - V. S. tem uma natureza de sensitiva; por outra, toma os recados na escada. Acredite ou não, o que lhe digo é a pura verdade. Não vá pensar que o afirmo assim para conservá-lo junto de mim: estimara mais o contrário.

Durv. - (sentando-se) Talvez queiras fazer crer que Sofia é alguma fruta passada, ou jóia esquecida no fundo da gaveta por não estar em moda. Estais enganada. Acabo de vê-la; acho-lhe ainda o mesmo rosto: vinte e oito anos, apenas.

Ros. - Acredito.

Durv. - É ainda a mesma: deliciosa.

Ros. - Não sei se ela lhe esconde algum segredo.

Durv. - Nenhum.

Ros. - Pois esconde. Ainda lhe não mostrou a certidão de batismo. (vai sentar-se ao lado oposto)

Durv. - Rosinha! E depois, que me importa? ela é ainda aquele querubim do passado. Tem uma cintura... que cintura!

Ros. - É verdade. Os meus dedos que o digam!

DuRv. - Hein? E o corado daquelas faces, o alvo daquele colo, o preto daquelas sobrancelhas? 
Ros. - (levantando-se) Ilusão! Tudo isso é tabuleta do Desmarais; aquela cabeça passa pelas minhas mãos. É uma beleza de pó de arroz: mais nada.

DuRv. - (levantando-se bruscamente) Oh! essa agora!

Ros. - (à parte) A pobre senhora está morta!

DuRv. - Mas, que diabo! Não é um caso de me lastimar; não tenho razão disso. O tempo corre para todos, e portanto a mesma onda nos levou a ambos folhagens da mocidade. E depois eu amo aquela engraçada mulher!

Ros. - Reciprocidade; ela também o ama.

Durv. - (com um grande prazer) Ah!

Ros. - Duas vezes chegou à estação do campo para tomar o wagon, mas duas vezes voltou para casa. Temia algum desastre da maldita estrada de ferro!

DuRv. - Que amor! só recuou diante da estrada de ferro!

Ros. - Eu tenho um livro de notas, donde talvez lhe possa tirar provas do amor da Sra. Sofia. É uma lista cronológica e alfabética dos colibris que por aqui têm esvoaçado.

Durv. - Abre lá isso então!

Ros. - (folheando um livro) Vou procurar.

DuRv. - Tem aí todas as letras?

Ros. - Todas. É pouco agradável para V. S.; mas tem todas desde A até o Z.

Durv. - Desejara saber quem foi a letra K.

Ros. —É fácil; algum alemão.

DuRv. - Ah! ela também cultiva os alemães?

Ros. - Durval é a letra D. - Ah! ei-lo: (lendo) "Durval, quarenta e oito anos de idade..."

Durv. - Engano! Não tenho mais de quarenta e seis.

Ros. - Mas esta nota foi escrita há dous anos.

Durv. - Razão demais. Se tenho hoje quarenta e seis, há dous tinha quarenta e quatro... é claro!

Ros. - Nada. Há dous anos devia ter cinqüenta.

Durv. - Esta mulher é um logogrifo!

Ros. - V. S. chegou a um período em sua vida em que a mocidade começa a voltar; em cada ano, são doze meses de verdura que voltam como andorinhas na primavera.

DURV. - Já me cheirava a epigrama. Mas vamos adiante com isso.

Ros. - (fechando o livro) Bom! Já sei onde estão as provas. (vai a uma gaveta e tira dela uma carta) Ouça: - "Querida Amélia..."

Durv. - Que é isso?

Ros. - Uma carta da ama a uma sua amiga. "Querida Amélia: o Sr. Durval é um homem interessante, rico, amável, manso como um cordeiro, e submisso como o meu Cupido..." (a Durval) Cupido é um cão d’água que ela tem.

DuRv. - A comparação é grotesca na forma, mas exata no fundo. Continua, rapariga.

Ros. - (lendo) "Acho-lhe contudo alguns defeitos...

Durv. - Defeitos?

Ros. - “Certas maneiras, certos ridículos, pouco espírito, muito falatório, mas afinal um marido com 
todas as virtudes necessárias...

Durv. - É demais!

Ros. - "Quando eu conseguir isso, peço-te que venhas vê-lo como um urso na chácara do Souto".

DuRv. - Um urso!

Ros. - (lendo) "Esquecia-me de dizer-te que o Sr. Durval usa de cabeleira". (fecha a carta)

Durv. - Cabeleira! é uma calúnia! Uma calúnia atroz! (levando a mão ao meio da cabeça, que está calva) Se eu usasse de cabeleira...

Ros. - Tinha cabelos, é claro.

DuRv. - (passeando com agitação) Cabeleira! E depois fazer-me seu urso como um marido na chácara do Souto.

Ros. - (às gargalhadas) Ah! ah! ah! (vai-se pelo fundo)

\section{Cena VII}

\section{DuRval (passeando)}

É demais! e então quem fala! uma mulher que tem umas faces... Oh! é o cúmulo da impudência! É aquela mulher furta-cor, aquele arco-íris que tem a liberdade de zombar de mim!... (procurando) Rosinha! Ah! foi-se embora... (sentando-se) Oh! se eu me tivesse conservado na roça, ao menos lá não teria destas apoquentações!... Aqui na cidade, o prazer é misturado com zangas de acabrunhar o espírito mais superior! Nada! (levanta-se) Decididamente volto para lá... Entretanto, cheguei há pouco... Não sei se deva ir; seria dar cavaco com aquela mulher; e eu... Que fazer? Não sei, deveras!

\section{Cena VIII}

Durval e Bento (de paletó, chapéu de palha, sem botas)

BENT. - (mudando a voz) Para a Sra. Rosinha. (põe o ramalhete sobre a mesa)

Durv. - Está entregue.

BENT. - (à parte) Não me conhece! Ainda bem.

Durv. - Está entregue.

BENT. - Sim, senhor! (sai pelo fundo)

\section{Cena IX}

DURVAL (só, indo buscar o ramalhete)

Ah! ah! flores! A Sra. Rosinha tem quem lhe mande flores! Algum boleeiro estúpido. Estas mulheres são de um gosto esquisito às vezes! — Mas como isto cheira! Dir-se-ia um presente de fidalgo! (vendo a cartinha) Oh! que é isto? Um bilhete de amores! E como cheira! Não conheço esta letra; o talho é rasgado e firme, como de quem desdenha. (levando a cartinha ao nariz) Essência de violeta, creio eu. É uma planta obscura, que também tem os seus satélites. Todos os têm. Esta cartinha é um belo assunto para uma dissertação filosófica e social. Com efeito: quem diria que esta moça, colocada tão baixo, teria bilhetes perfumados!... (leva ao nariz) Decididamente é essência de magnólias! 


\section{Cena X}

Rosinha (no fundo); DuRval (no proscênio)

Ros. - (consigo) Muito bem! Lá foi ela visitar a sua amiga no Botafogo. Estou completamente livre. (desce)

DuRv. - (escondendo a carta) Ah! és tu? Quem te manda destes presentes?

Ros. - Mais um. Dê-me a carta.

Durv. - A carta? É boa! é cousa que não vi.

Ros. - Ora não brinque! Devia trazer uma carta. Não vê que um ramalhete de flores é um estafeta mais seguro do que o correio da corte!

Durv. - (dando-lhe a carta) Aqui a tens; não é possível mentir.

Ros. - Então! (lê o bilhete)

Durv. - Quem é o feliz mortal?

Ros. - Curioso!

DuRv. - É moço ainda?

Ros. - Diga-me: é muito longe daqui a sua roça?

DURV. - É rico, é bonito?

Ros. - Dista muito da última estação?

DuRv. - Não me ouves, Rosinha?

Ros. - Se o ouço! É curioso, e vou satisfazer-lhe a curiosidade. É rico, é moço e é bonito. Está satisfeito?

DuRv. - Deveras! E chama-se?...

Ros. - Chama-se... Ora eu não me estou confessando!

DuRv. - És encantadora!

Ros. - Isso é velho. É o que me dizem os homens e os espelhos. Nem uns nem outros mentem.

Durv. - Sempre graciosa!

Ros. - Se eu o acreditar, arrisca-se a perder a liberdade... tomando uma capa...

Durv. - De marido, queres dizer (à parte) ou de um urso! (alto) Não tenho medo disso. Bem vês a alta posição... e depois eu prefiro apreciar-te as qualidades de fora. Talvez leve a minha amabilidade a fazer-te uma madrigal.

Ros. - Ora essa!

DURV. - Mas, fora com tanto tagarelar! Olha cá! Eu estou disposto a perdoar aquela carta; Sofia vem sempre ao baile?

Ros. - Tanto como o imperador dos turcos... Recusa.

DuRv. - Recusa! é o cúmulo da... E por que recusa?

Ros. — Eu sei lá! Talvez um nervoso; não sei!

Durv. - Recusa! Não faz mal... Não quer vir, tanto melhor! Tudo está acabado, Sra. Sofia de Melo! Nem uma atenção ao menos comigo, que vim da roça por sua causa unicamente! Recebe-me com agrado, e depois faz-me destas!

Ros. - Boa noite, Sr. Durval.

DuRV. - Não te vás assim; conversemos ainda um pedaço. 
Ros. - Às onze horas e meia... interessante conversa!

Durv. - (sentando-se) Ora que tem isso? Não são as horas que fazem a conversa interessante, mas os interlocutores.

Ros. - Ora tenha a bondade de não dirigir cumprimentos.

DuRv. - (pegando-lhe na mão) Mal sabes que tens as mãos, como as de uma patrícia romana; parecem calçadas de luva, se é que uma luva pode ter estas veias azuis como rajadas de mármore.

Ros. - (à parte) Ah! hein!

Durv. - E esses olhos de Helena!

Ros. - Ora!

Durv. - E estes braços de Cleópatra!

Ros. - (à parte) Bonito!

DuRv. - Apre! queres que esgote a história?

Ros. - Oh! não!

DuRv. - Então por que se recolhe tão cedo a estrela d'alva?

Ros. - Não tenho outra cousa a fazer diante do sol.

Durv. - Ainda um cumprimento! (vai à caixa de papelão) Olha cá. Sabes o que há aqui? Um dominó.

Ros. - (aproximando-se) Cor-de-rosa! Ora vista, há de ficar-lhe bem.

Durv. - Dizia um célebre grego: dê-me pancadas, mas ouça-me! - Parodio aquele dito: - Ri, graceja, como quiseres, mas hás de escutar-me (desdobrando o dominó): não achas bonito?

Ros. - (aproximando-se) Oh! decerto!

Durv. - Parece que foi feito para ti!... É da mesma altura. E como te há de ficar! Ora, experimenta!

Ros. - Obrigado.

DuRv. - Ora vamos! experimenta; não custa.

Ros. - Vá feito se é só para experimentar.

Durv. - (vestindo-lhe o dominó) Primeira manga.

Ros. - E segunda! (veste-o de todo)

Durv. - Delicioso. Mira-te naquele espelho. (Rosinha obedece) Então!

Ros. - (passeando) Fica-me bem?

Durv. - (seguindo-a) A matar! a matar! (à parte) A minha vingança começa, Sra. Sofia de Melo! (a

Rosinha) Estás esplêndida! Deixa dar-te um beijo?

Ros. - Tenha mão.

DuRv. - Isso agora é que não tem graça!

Ros. - Em que oceano de fitas e de sedas estou mergulhada! (dá meia-noite) Meia-noite!

DuRv. — Meia-noite!

Ros. - Vou tirar o dominó... é pena!

Durv. - Qual tirá-lo! fica com ele. (pega no chapéu e nas luvas)

Ros. - Não é possível.

Durv. - Vamos ao baile mascarado.

Ros. - (à parte) Enfim. (alto) Infelizmente não posso. 
DuRV. - Não pode? e então por quê?

Ros. - É segredo.

Durv. - Recusas? Não sabes o que é um baile. Vais ficar extasiada. É um mundo fantástico, ébrio, movediço, que corre, que salta, que ri, em um turbilhão de harmonias

extravagantes!

Ros. - Não posso ir. (batem à porta) É Bento.

DuRv. - Quem será?

Ros. - Não sei. (indo ao fundo) Quem bate?

Bent. - (fora com a voz contrafeita) O hidalgo Don Alonso da Sylveira y Zorrilla y Gudines y Guatinara y Marouflas de la Vega!

DuRv. - (assustado) É um batalhão que temos à porta! A Espanha muda-se para cá?

Ros. - Caluda! não sabe quem está ali? É um fidalgo da primeira nobreza de Espanha. Fala à rainha de chapéu na cabeça.

Durv. - E que quer ele?

Ros. - A resposta daquele ramalhete.

Durv. - (dando um pulo) Ah! foi ele...

Ros. - Silêncio!

BENT. - (fora) É meia-noite. O baile vai começar.

Ros. - Espere um momento.

Durv. - Que espere! Mando-o embora. (à parte) É um fidalgo!

Ros. - Mandá-lo embora? pelo contrário; vou mudar de dominó e partir com ele.

DuRv. - Não, não; não faças isso!

BENT. - (fora) É meia-noite e cinco minutos. Abre a porta a quem deve ser teu marido.

DuRv. - Teu marido!

Ros. - E então!

BENT. - Abre! abre!

DURV. — É demais! Estás com o meu dominó... hás de ir comigo ao baile!

Ros. - Não é possível; não se trata a um fidalgo espanhol como a um cão. Devo ir com ele.

Durv. - Não quero que vás.

Ros. - Hei de ir. (dispõe-se a tirar o dominó) Tome lá...

DuRv. - (impedindo-a) Rosinha, ele é um espanhol, e além de espanhol, fidalgo. Repara que é uma dupla cruz com que tens de carregar.

Ros. — Qual cruz! E não se casa ele comigo?

Durv. - Não caias nessa!

Bent. - (fora) Meia-noite e dez minutos! então vem ou não vem?

Ros. - Lá vou. (a Durval) Vê como se impacienta! tudo aquilo é amor!

DuRv. - (com explosão) Amor! E se eu te desse em troca daquele amor castelhano, um amor brasileiro ardente e apaixonado? Sim, eu te amo, Rosinha; deixa esse espanhol tresloucado!

Ros. - Sr. Durval!

Durv. - Então, decide! 
Ros. - Não grite! aquilo é mais forte do que um tigre de Bengala.

Durv. - Deixa-o; eu matei as onças do Maranhão e já estou acostumado com esses animais. Então? vamos! eis-me a teus pés, ofereço-te a minha mão e a minha fortuna!

Ros. - (à parte) Ah... (alto) Mas o fidalgo?

BENT. - (fora) É meia-noite e doze minutos!

Durv. - Manda-o embora, ou senão, espera. (levanta-se) Vou matá-lo; é o meio mais pronto.

Ros. - Não, não; evitemos a morte. Para não ver correr sangue, aceito a sua proposta.

Durv. - (com regozijo) Venci o castelhano! É um magnífico triunfo! Vem, minha bela; o baile nos espera!

Ros. - Vamos. Mas repare na enormidade do sacrifício.

Durv. - Serás compensada, Rosinha. Que linda peça de entrada! (à parte) São dous os enganados - o fidalgo e Sofia (alto) Ah! ah! ah!

Ros. - (rindo também) Ah! ah! ah! (à parte) Eis-me vingada!

Durv. - Silêncio! (vão pé ante pé pela porta da esquerda. Sai Rosinha primeiro, e Durval, da soleira da porta para a porta do fundo, a rir às gargalhadas)

\section{Cena última}

Bent. - (abrindo a porta do fundo) Ninguém mais! Desempenhei o meu papel: estou contente! Aquela subiu um degrau na sociedade. Deverei ficar assim? alguma baronesa não me desdenharia decerto. Virei mais tarde. Por enquanto, vou abrir a portinhola. (vai a sair e cai o pano)

\section{OdisséIA dos VinTe ANOS}

(Fantasia num ato)

Luís, pintor e poeta

Álvaro

Alberto

Luiza

Maria

Um gabinete de trabalho

$$
\text { Álvaro e Luís }
$$

ÁLV. - Estás triste, Luís!

Luís (deixando o pincel) - Estou doente. Doença d’alma, a pior delas. Faz rir: não faz, esta reprodução de úlceras aos vinte anos; esta transformação sucessiva dos Manfredos? Ninguém crê nessas cousas; entretanto se há verdade no mundo, é este o estado em que estou.

Álv. - Sabes a minha opinião? És fraco demais. 
Luís (Indo à janela) — Fraco? Agora quem se ri sou eu. Fraco! onde queres que eu vá buscar forças? Se eu sinto em mim uma prostração, se eu sinto que nenhum desses músculos morais que são os raios da força, conserva aquela rigidez primitiva, que acompanha sempre a mocidade e que por momentos fez de mim de Hércules. Agradeço que me lastimes, mas não me acuses.

Álv. - Vem cá; quando temos vinte anos de presente, e cinqüenta de futuro talvez, a alma levanta-se, não se deixa quebrar. Ajunta depois talento a esses vinte anos, e...

Luís - Tudo isso é vão. Teoria, Álvaro, realidade para uns; para mim sonhos e mais nada! Falo-te assim, porque sei que estamos sós e que tu não estás contaminado. Bem vês, como eu rio, como sou jovial fora daqui; estas paredes são a minha vida íntima. Consentes que te fale?

Álv. - Ouço-te. Mas não me impeças um remédio no caso que t’o possa dar.

Luís (rindo) - Remédio! A minha tísica do espírito está no último grau; ninguém me pode salvar.

Álv. - Ninguém!

Luís - Quase ninguém. Há talvez alguma cousa que me cure; mas isso é um remédio supremo, e esse não está nas mãos de qualquer.

Álv. - Veremos.

Luís - Ouve-me agora. Há uma ordem de poetas modernos que por hábito de leitura e mania de rapaz, acreditaram estar deveras doentes da alma. É culpa de Byron e de outros; Manfredo é um grão que germinou uma raça. Toda essa procissão de Werthers pálidos, lá vão como fotografias do tipo primitivo. Eu conheço desses profanadores do ceticismo, doentes por cálculo, de que Molière se esqueceu. Esta raça produziu necessariamente uma outra que se constituiu o lábaro dela; os satíricos, os que não acreditando nesses mórbidos dos vinte anos, arrancaram-lhes a máscara em pleno século.

Álv. - Era necessário.

Luís - Era necessário, sim. Mas o que aconteceu? É que aqueles que realmente sofrem, aqueles que têm em cada dia, não vinte e quatro horas de vida, mas um degrau do patíbulo para que sobem lentamente; esses são obrigados a copiar a máscara do primeiro cínico e a colá-la à cara, como a túnica de Nesso. Compreendes! não há uma existência pior. Andar em um carnaval perpétuo! Vê lá: tens um remédio para isto?

Álv. - Tenho. Onde está a razão dessa prostração moral?

Luís - Onde? não o sei. Mas deixa confiar-te os sintomas; verás depois. Tenho vinte anos; perdi minha mãe aos nove. Fiquei por conseguinte só: só, compreendes bem, quando não temos o seio materno para encostar a cabeça; é a solidão que nos cerca, solidão do deserto, solidão dos limbos povoada de sombras, e deserta como o nada! Achei-me só, pois. Vês-me com vinte anos, cheio de mocidade: mas que mocidade! nem um afeto! nem um coração! nada! Aqui e ali só encontro o desdém! Queria amigos e tenho protetores! queria corações e encontro espíritos! nem um seio de mulher, nem uma cabeça de vinte anos que case as suas com as minhas primaveras! Só, isolado no meio da sociedade, que corre e salta, ama e delira, eu sou como aquele Tântalo dos Eddas pagãos; vejo passar por mim os corações e os afetos e não posso agarrar um só. Parece que vento de temporal os leva. É demais. Sou pobre como vês: quem me quereria assim? A humanidade é como o touro, gosta de púrpuras, gosta dos ouropéis. O século é dos cínicos e dos parvos. Tudo está prostituído!

Álv. - Assim, não crês em cousa alguma? 
Luís - Creio. Creio em Deus, e creio em mim. Mais claro: creio que sou uma vítima que nem devo olhar com asco para os instrumentos do meu suplício; creio que Deus ri-se deveras de toda esta resolução que se opera aqui por baixo; e que em um dia bem pode com um simples movimento de mão atirar com toda esta espécie humana para os abismos do ignoto. É que ele não quer! Conta com o seu triunfo e deixa os homens o seu. É razoável: cada um tem a sua hora: terei eu a minha?

Álv. (pensativo) - Esperas por ela?

Luís - Podia esperar, mas nem tenho forças para isso. Entretanto vi há dias uma gravura inglesa que definia talvez a minha existência. Representava esfera no meio com o dístico: - Índia - em torno estavam as entidades comprometidas nessa questão européia que se divertiam em atirar reciprocamente essa bola com o pé. Eu sou assim. Estou no meio dos homens, como aquela esfera e rolo ao impulso de cada pé que me encontra. Mas queres saber... tive uma fraqueza; não rias. Para completar o quadro, um dos indivíduos do jogo estava a um canto com o pé em uma das mãos; tive uma veleidade; acreditei que havia, como a bola, ferir alguém. Mas passou. Era uma tolice.

Álv. - Causas-me pena!

Luís - És bom; eu te conheço. Tanto melhor. Mas cala-te; vem alguém!

[não assinado]

\section{CARNICEIRA A VAPOR}

O estabelecimento de M. Roviello, nas proximidades da cidade do Brooklyn, nos Estados Unidos, é um matadouro de porcos, onde se empregam os aparelhos mecânicos a vapor para o tríplice processo de - sangrar ou matar, esquartejar e salgar esses animais.

M. Commetant, na obra que publicou em 1857 sobre os Estados Unidos, descreve este singular estabelecimento em toda a sua extensão; porém, nós vamos dar aos leitores uma sucinta idéia dele, não somente para conhecerem esta carniceira a vapor, como para saberem até onde se tem levado o emprego destas máquinas.

O estabelecimento, de que vamos tratar, vasto, como deve o ser para estrangular diariamente centenas de porcos, compõe-se de quatro extensas casas, que se comunicam entre si por pontes pênseis. Ao redor, e em todos os sentidos, se distinguem diversos cercados, fechados, onde formigam inumeráveis porcadas pertencentes a diferentes criadores.

Longe nos levaria a descrição do maquinismo, peça por peça, o que só interessaria a quem quisesse organizar uma Companhia de - açougues monstros - de carne de porco; assim, vamos ser simplesmente espectadores, para o que não basta somente - presenciar - é preciso também ter ânimo para - ver - .

A matança vai começar.

O engenheiro em chefe faz um sinal: abre-se logo a comunicação do exterior para o primeiro compartimento da máquina chamada degoladouro. 
O ingresso para este compartimento é feito por um estreito corredor, que se afunila, e só podem chegar ao compartimento de que se trata um porco por sua vez. Ao termo deste corredor são os porcos obrigados a parar, e logo, com rapidez de raio, enormes facões manejados por um punho tão forte, como o do vapor os transpassem certeiramente a sangrar pelo coração.

Quanto pode a mecânica!

Isto feito, sem demora, cada porco é agarrado pelos quartos e traseiros por grampos, e assim violentamente levantados e conduzidos em enfiada, como um rosário, para serem mergulhados em um vasto reservatório de água fervendo, donde saem para sofrerem o processo final da pelação entre grandes escovas.

O vapor ainda não terminou aqui a sua missão. O porco ou porca (que neste estado é sempre - porco - nos açougues) é ainda agarrado convenientemente pelos grampos, e em um movimento brutal é arremessado para um lugar apropriado, onde a máquina leva as suas afiadas facas, e de uma vez só abre desde o focinho até a cauda.

Neste estado, saltam logo alguns operários para arrancar os intestinos, ou quaisquer outras partes não aproveitáveis do porco, e os lançam em uma vala que atravessa o estabelecimento, que é constantemente lavada pelas águas do rio Ohio.

A máquina ainda continua a trabalhar, levando o porco ao horrível compartimento do talho; aí se despedaça o animal com aquela regularidade e simetria que lhe é devida, e passa por montões de sal.

Os encarregados do recebimento da carne reúnem os pedaços e os põem no fumeiro ou os embarrilam na salmoura.

Eis a carniceira feita, e com tão grande presteza, que perde-se de vista os múltiplos processos porque passam os pobres animais!

Os porcos sucedem aos porcos, como os cavalinhos de pau da Maxambomba, que mal são percebidos no rápido circular em torno do mastro! $\mathrm{E}$ juntai a este movimento o grunhido rouco e sinistro das vítimas que são degoladas ou sangradas, e dos que semivivos seguem em rosários para a terrível caldeira d'água em ebulição! Esta lúgubre e horrível música não tem fim, porque, enquanto alguns porcos morrem na água fervendo, já outros são esfaqueados, e assim não cessa de haver sempre um contingente de lamentações!!!

Terminemos a nossa missão de levar o leitor a visitar o estabelecimento de M. Roviello, nos Estados Unidos.

Agora resta-nos entrega-lo à liberdade de seu pensar, para que julguem até onde se tem empregado as máquinas movidas a vapor.

A este respeito diz um mecânico francês:

"Où la mécanique va-t-elle se nicher!"

M. A. 


\section{ANEDOTA}

\section{O Que É Estar em Dia com as Ciências}

Um dos nossos fazendeiros, acolhedor de grande número de visitantes da corte, estava há muitos dias admirado em ver que a caça de um de seus hóspedes era sempre morta pela cauda, $\mathrm{e}$ querendo penetrar ou saber a causa de semelhante ocorrência, perguntou a este amador de caçadas a razão porque sempre feria a caça pela cauda. - É de fácil concepção - respondeu o nosso cortesão em tom catedrático: as espingardas que as ciências mandam presentemente fazer uso, são as que se carregam pela culatra, como a que trouxe a corte, e ferindo as balas em pontos semelhantes por onde são metidas nas armas, necessariamente a minha espingarda somente fere pela cauda. Isto é teórico e prático.

O fazendeiro ficou ainda mais admirado, e exclamou: O que é estar em dia com as ciências.

M. A.

\section{O Termômetro Parlamentar}

Um jornal belga, L'Observateur, anuncia debaixo deste título a invenção de um novo termômetro, do qual vamos dar uma idéia da sua construção e para que fim se destina.

As sessões da Assembléia, diz L'Observateur nem sempre são publicadas fielmente nos diversos jornais que os inserem; porque enquanto este recheia a fala de muitos apoiados, aquele outro semeia na mesma fala os não apoiados; se, para uns o orador mereceu ser ouvido com silêncio profundo, para outros isto se altera em hilariedade prolongada, e assim sempre se dão tais contradições, que o leitor imparcial não pode crer nos parênteses e notas dos redatores.

Semelhantes ocorrências não poderão haver mais com a existência do - termômetro parlamentar - porque este instrumento registra continuadamente a temperatura real das sessões, e, para bem dizer, a opinião íntima dos membros, e a resultante se apresenta logo à vista de todos os espectadores.

Este instrumento compõe-se de um tubo de vidro de polegada e meia de diâmetro interno, disposto por detrás da cadeira presidencial e encostado a uma régua ou escala centígrada, que parte do assoalho e termina no teto da sala. O tubo enche-se de um líquido colorado, como nos termômetros ordinários.

Um outro tubo de cobre, partindo da cuveta ou reservatório inferior, se ramifica por debaixo dos estrados, em tantos pequenos tubos quantos são os assentos ou cadeiras dos membros. Estes pequenos tubos são terminados por saquinhos de borracha de forma de pêras, que ficam debaixo dos pés de cada um membro.

Quando não há discussão, todo o líquido se conserva contido nos saquinhos e nos tubos de ramificação; porém logo que algum membro fala, os que aprovam ou querem animar o orador 
comprimem mais ou menos o saquinho e o líquido aparece no grande tubo de vidro do termômetro.

Os taquígrafos são obrigados a notar de 5 em 5 minutos os graus de temperatura da sessão, indicados na régua ou escala por elevação ou abaixamento da coluna líquida, - fiel intérprete dos sentimentos da Assembléia. Desta forma, obtém-se a medida exata dos efeitos produzidos pelo orador, manifestando-se as sensações ou mudez, calma e sem interrupções.

Nós esperamos, acrescenta o jornal belga, que este engenhoso instrumento - registrador da opinião nacional - pouco dispendioso na construção e exato nas suas funções, não tardará a ser adotado em todas as Assembléias deliberantes, e servirá muito para animar os bons oradores e afugentar os maçantes.

(Ext.)

M. A.

\title{
Queda Que as Mulheres Têm para os Tolos
}

\author{
Advertência $^{14}$
}

Este livro é curto, talvez devera sê-lo mais.

Desejo que ele agrade, como me sai das mãos, mas é com pesar que me vanglorio por esta obra.

Falar do amor das mulheres pelos tolos, não é arriscar ter por inimigas a maioria de um e outro sexo?

Diz-se que a matéria é rica e fecunda; eu acrescento que ela tem sido tratada por muitos. Se tenho, pois, a pretensão de ser breve, não tenho a de ser original.

Contento-me em repetir o que se disse antes de mim; minhas páginas conscienciosas são um resumo de muitos e valiosos escritos. Propriamente falando, é uma comparação científica, e eu obteria a mais doce recompensa de meus esforços, como dizem os eruditos, se inspirasse aos leitores a idéia de aprofundar um tão importante exemplo.

Quanto à imparcialidade que presidiu à redação deste trabalho, creio que ninguém a porá em dúvida.

Exalto os tolos sem rancor, e se critico os homens de espírito, é com um desinteresse, cuja extensão facilmente se compreenderá.

Il est des noeuds secrets, il est des nymphes ${ }^{15}$

14. Esta "Advertência" não consta na primeira edição publicada na Marmota, é oriunda da primeira edição em volume, editada também em 1861 na tipografia de Paula Brito.

15. Esta frase marca o início do texto no periódico. No volume consta "sympathies" no lugar de nymphes. 
Passa em julgado que as mulheres lêem de cadeira em matéria de fazendas, pérolas e rendas,e que, desde que adotam uma fita, deve-se crer que a essa escolha presidiram motivos plausíveis.

Partindo deste princípio, entraram os filósofos a indagar se elas mantinham o mesmo cuidado na escolha de um amante, ou de um marido.

Muitos duvidaram.

Alguns emitiram como axioma - que o que determinava as mulheres neste ponto, não era, nem a razão, nem o amor, nem mesmo o capricho; que se um homem lhes agradava, era por se ter apresentado primeiro que os outros, e que sendo este substituído por outro, não tinha esse outro senão o mérito de ter chegado antes do terceiro.

Permaneceu por muito tempo este sistema irreverente.

Hoje, graças a Deus, a verdade se descobriu: veio a saber-se que as mulheres escolhem com pleno conhecimento do que fazem. Comparam, examinam, pesam, e só se decidem por um, depois de verificar nele a preciosa qualidade que procuram.

Essa preciosidade é... a toleima!

II

Desde a mais remota antigüidade, sempre as mulheres tiveram a sua queda para os tolos.

Alcibíades, Sócrates e Platão foram sacrificados por elas aos presumidos do tempo. Turenne, la Rochefoucauld, Racine e Molière foram traídos por suas amantes, que se entregaram a basbaques notórios. No século passado todas as boas fortunas foram reservadas aos pequenos abades. Estribados nesses ilustres exemplos, os nossos contemporâneos continuam a idolatrar os descendentes dos ídolos das suas avós.

Não é nosso fim censurar uma tendência, que parece incrível; o que queremos é motivá-la.

Por menos observador e menos experiente que seja qualquer pessoa, reconhece que o toleima é quase sempre um penhor de triunfo. Desgraçadamente ninguém pode por sua própria vontade gozar das vantagens da toleima. A toleima é mais do que uma superioridade ordinária: é um dom, é uma graça, é um selo divino.

"O tolo não se faz, nasce feito."

Todavia, como o espírito e como o gênio, a toleima natural fortifica-se e estende-se pelo uso que se faz dela. É estacionária no pobre diabo, que raramente pode aplicá-la; mas toma proporções desmarcadas nos homens a quem a fortuna, ou a posição social, cedo leva à prática do mundo. Este concurso da toleima imposta e da toleima adquirida, é que produz a mais temível espécie de todos, os tolos que o acadêmico Trublet chamou tolos completos, tolos integrais, tolos no apogeu da toleima.

O tolo é abençoado do céu pelo fato de ser tolo, e é pelo fato de ser tolo, que lhe vem a certeza de que qualquer carreira que tome, há de chegar felizmente ao termo. Nunca solicita empregos, aceitaos em virtude do direito que lhe é próprio: Nominor leo. Ignora o que é ser corrido ou desdenhado; onde quer que chegue é festejado como um conviva que se espera.

O que opor-lhe como obstáculo? É tão enérgico no choque, tão igual nos esforços e tão seguro no resultado! É rocha desligada, que rola, corre, salta e avança caminho por si, precipitada pela sua própria massa. 
Sorri-lhe a fortuna particularmente ao pé das mulheres. Mulher alguma resistiu nunca a um tolo. Nenhum homem de espírito teve ainda impunemente um parvo como rival. Por quê?... Há necessidade de perguntar por quê? Em questão de amor, o paralelo a estabelecer entre o tolo e o homem de siso, não é para confusão do último?

III

Em matéria de amor, deixa-se o homem de espírito embalar por estranhas ilusões. As mulheres são para ele entes de mais elevada natureza que a sua, ou pelo menos empresta-lhes as próprias idéias, supõe-lhes um coração como o seu, imagina-os capazes, como ele, de generosidade, nobreza e grandeza. Imagina que para agradar-lhes é preciso ter qualidades acima do vulgar. Naturalmente tímido, exagera mais ao pé delas a sua insuficiência; o sentimento de que lhe falta muito, torna-o desconfiado, indeciso, atormentado. Respeitoso até a timidez, não ousa exprimir o seu amor em palavras; exala-o por meio de uma não interrompida série de meigos cuidados, ternos respeitos e atenções delicadas. Como nada quer à custa de uma indignidade, não se conserva continuamente ao pé daquela que ama, não a persegue, não a fatiga com a sua presença. Para interessá-la em suas mágoas, não toma ares sombrios e tristes; pelo contrário, esforça-se por ser sempre bom, afetuoso e alegre junto dela. Quando se retira da sua presença, é que mostra o que sofre, e derrama as suas lágrimas em segredo.

O tolo, porém, não tem desses escrúpulos. A intrépida opinião que ele tem de si próprio, o reveste de sangue frio e segurança. Satisfeito de si, nada lhe paralisa a audácia. Mostra a todos que a ama, e solicita com instância provas de amor. Para fazer-se notar daquela que ama, importuna-a, acompanha-a nas ruas, vigia-a nas igrejas e espia-a nos espetáculos. Arma-lhe laços grosseiros. À mesa, oferece-lhe uma fruta para comerem ambos, ou passa-lhe misteriosamente, com muito jeito, um bilhete de amores. Aperta-lhe a mão a dançar e saca-lhe o ramalhete de flores no fim do baile. Numa noite de partida, diz-lhe dez vezes ao ouvido: “Como é bela!", porquanto revela-lhe o instinto, que pela adulação é que se alcançam as mulheres, bem como se as perde, tal como acontece com os reis. De resto, como nos tolos tudo é superficial e exterior, não é o amor um acontecimento que lhes mude a vida: continuam como antes a dissipá-la nos jogos, nos salões e nos passeios.

\section{IV}

O amor, disse alguém, é uma jornada, cujo ponto de partida é o sentimento, e cujo termo inevitável - a sensação. Se é isto verdade, o que há a fazer, é embelecer a estrada e chegar o mais tarde possível ao fim. Ora, quem melhor que o homem de espírito sabe parolar à beira do caminho, parar e colher flores, sentar-se às sombras frescas, recitar aventuras e procurar desvios e delongas? Um caracol de cabelos mal arranjado, um cumprimento menos apressado que de costume, um som de voz discordante, uma palavra mal escolhida, tudo lhe é pretexto para demorar os passos a prolongar os prazeres da viagem. Mas quantas mulheres apreciam esses castos manejos, e compreendem o encanto dessas paradas à borda de uma veia límpida que reflete o céu? Elas querem amar, qualquer que seja a sua natureza, e o que o tolo lhes oferece é lhes bastante, por mais insípido que seja. 
$\mathrm{V}$

O homem de espírito quando chega a fazer-se amar, não goza de uma felicidade completa. Atemorizado com a sua ventura, trata antes de saber porque é feliz. Pergunta por que e como é amado: se, para uma amante, é ele uma necessidade, ou um passatempo; se ela cedeu a um amor invencível: enfim, se é ele amado por si mesmo. Cria ele próprio e com engenho as suas mágoas e cuidados: é como o Sibarita que, deitado em um leito de flores, sentia-se incomodado pela dobra de uma folha de rosa. Num olhar, numa palavra, num gesto, acha ele mil nuanças imperceptíveis, desde que se trata de interpretá-las contra si. Esquece os encômios que levemente o tocam, para lembrar-se somente de uma observação feita ao menor dos seus defeitos e que bastante o tortura. Mas, em compensação desses tormentos, há no seu amor tanto encanto e delícias! Como estuda, como retrata, como saboreia as volúpias mais fugitivas até ao último rompimento! Como a sua sensibilidade especial sabe descobrir o encanto das criancices frívolas, dos invisíveis atrativos, dos nadas adoráveis!

O tolo é um amante sempre contente e tranqüilo. Tem tão robusta confiança nos seus predicados, que antes de ter provas, já mostra a certeza de ser amado. E assim deve ser. Em sua opinião faz uma grande honra à mulher a quem dedica os seus eflúvios. Não lhe deve felicidade; ele é que lha dá e como tudo o leva a exagerar o benefício, não lhe vem à idéia de que se possa ter para com ele ingratidões. Assim, no meio das alegrias do amor, saboreia ainda a embriaguez da fatuidade. Mas como, em definitivo, é ele próprio o objeto de seu culto, depressa o tolo se aborrece, e como o amor para ele não é mais que um entretenimento que passa, os últimos favores, longe de o engrandecerem mais, desligam-no pela sociedade.

VI

O homem de espírito vê no amor um grande e sério negócio, ocupa-se dele como do mais grave interesse de sua vida, sem distração, nem reserva. Pode perder nele algumas das suas qualidades viris, mas é para crescer em abnegação, em dedicação, em bondade. Suporta tudo daquela que ama sem nada exigir dela. Quando ela atende a alguns dos seus votos, quando previne alguns dos seus desejos, longe de ensoberbecer-se, agradece com uma efusão mesclada de surpresa. Perdoa-lhe generosamente todos os males que lhe causa, porque muito orgulhoso para enraivecer-se ou lastimarse, não sabe provocar nem a piedade que enternece, nem o medo que faz calar. Oh! que inferno, se a má ventura lhe depara uma mulher bela e má, uma namoradeira fria de sentidos, ou uma moça de rabugice precoce!

Sofre então vivamente com a perfídia da mulher amada, mas desculpa-a pela fragilidade do sexo. A sua indulgência pode então conduzi-lo à degradação. Ele segue a olhos fechados o declive que o arrasta ao abismo, sem que a queixa, a ambição, a fortuna possam retê-lo.

O néscio escapa a estes perigos. Como não é ele quem ama, é ele quem domina. Para vencer uma mulher finge por alguns momentos o excesso de desespero e de paixão; mas isso não passa de um meio de guerra, tática de cerco para enganar e seduzir o inimigo. Logo depois recobra ele a tirania, e não a abdica mais. Para entreter-se nisso, tem o tolo o seu método, as suas regras, a sua linha de conduta. É indiscreto por princípio, porquanto divulgando os favores que recebe, compromete a que lhe concede e ao mesmo tempo afasta as rivalidades nascentes. É suscetível pela razão, cioso por 
cálculo, a fim de promover essas proveitosas rezingas, que lhe servem, a seu grado, para conduzir a uma ruptura definitiva, ou para exigir um novo sacrifício. Mostra uma cruel indiferença, indicando pouca confiança nas provas de simpatia que lhe dão. Num baile, proibindo à sua amante de dançar, não faz caso dela de propósito. Aflige-a com aparências de infidelidade, falta à hora marcada para se encontrarem, ou depois de se ter feito esperar, vem, dando desculpas equívocas de sua demora. Hábil em semear a inquietação e o susto, faz-se obedecer à força de ser tirano, e acaba por inspirar uma afeição sincera à força de promovê-la.

\section{VII}

O homem de espírito, amestrado com o vácuo imenso, que deixa no coração uma afeição que se perde, só rompe o laço que o prende à causa de dilacerações interiores.

Como bem se disse, sendo preciso um dia para conseguir, é preciso mil para se reconquistar.

Mesmo no momento em que volta a ser livre: quantas vezes um sorriso, um meneio de cabeça, uma maneira de puxar o vestido, ou de inclinar o chapelinho de sol, não o faz recair no seu antigo cativeiro!

De resto, a mulher a quem ele tiver revelado o segredo do seu coração, ficará sempre para ele como ser à parte. Não a esquece nunca.

Morto, ou desesperado, nutre por aquela que a perdeu longas saudades. Perseguido pela lembrança que dela conserva, descobre muitas vezes que as outras mulheres por quem se apaixona só têm o mérito de se parecerem com ela. Dá-se ele então a comparações que o desuniram, que o irritam, que o põem fora de si, exigindo no seu trajar, no seu andar e até no seu falar alguma cousa que lhe recorde o seu implacável ideal.

E se é ele o abandonado, que de torturas que sofre!

Viver sem ser amado parece-lhe intolerável. Nada pode consolá-lo ou distraí-lo.

No caso de tornar a ver os sítios que foram testemunhas da sua felicidade, envia à sua memória mil circunstâncias perseverantes e cruéis. Ali está a cerca cheirosa, cujos espinhos rasgaram o véu da infiel; aqui, o rio que a medrosa só ousa atravessar amparada pela sua mão; além está a alameda, cuja areia fina parece ter ainda o molde de seus ligeiros passos. Contempla na janela as longas e alvas cortinas, no peitoril os arbustos em flor, na relva a mesa, o banco, as cadeiras em que outrora se sentaram.

É possível que ele tenha mudado tão de repente? Pois não foi ainda ontem que de volta de um passeio ao bosque, ela lhe enxugou o suor da testa, e que a ela se prendia em doce e estranho amplexo?... Hoje, nem mais doçuras, nem mais apertos de mão, nem mais dessas horas ébrias em que todo o passado ficava esquecido! Ele está só, entregue a si mesmo, sem força, sem alvo: é o delírio do desespero.

O tolo está acima dessas misérias. Não o assusta um futuro prenhe de qualquer inquietação aflitiva. Sempre enrolado em uma bondade de inconstância, desfaz-se de uma amante sem luta, nem remorso; utiliza uma traição para voar a novas aventuras. Para ele nada há de terrível em uma separação, porque nunca supõe que se possa colocar a vida numa vida alheia, e que fazendo-se um hábito dessa comunidade de existência, faz-se pouco novamente sofrer, quando ela tiver de quebrar-se. 
Da mulher que deixa de amar, ele só conserva o nome, como o veterano conserva o nome de uma batalha para glorificar-se, ajuntando-o ao número das suas campanhas.

\section{VIII}

Há uma época em que custa-se muito a amar. Tendo visto e estudado um pouco a mulher, adquire-se uma certa dureza que permite aproximar-se sem perigo das mais belas e sedutoras. Confessa-se sem rebuço a admiração que elas inspiram, mas é uma admiração de artista, um entusiasmo sem ternura. Além disso, ganha-se uma penetração cruel para ver, através de todos os artifícios de casquilha, o que vale a submissão que elas ostentam, a doçura que afetam, a ignorância que fingem. E prenda-se um homem nessas condições!

De ordinário, é entre trinta e trinta e cinco anos que o coração do homem de espírito fecha-se assim à simpatia e começa a petrificar-se. É entretanto possível que nele tornem a aparecer os fogos da mocidade, e que ele venha a sentir um amor tão puro, tão fervente, tão ingênuo como nos frescos anos da adolescência; longe de ter perdido as perturbações, as apreensões, os transportes da alma amorosa, sente-os ele de novo com emoção mais profunda e dá-lhes um preço tanto mais elevado, quanto ele está certo de não os ver renascer.

Oh! então lastima-se o pobre insensato! Ei-lo obrigado a ajoelhar-se aos pés de uma mulher para quem é nada o mérito de caminhar pouco a pouco atrás de sua sombra, de fazer exercício em torno aos seus vestidos, de se extasiar diante de seus bordados, de lisonjear os seus enfeites. Ai, triste! esses longos suplícios o revoltam, e, Pigmalião desesperado, afasta-se de Galatéia, cujo amor se não pode reanimar.

Esses sintomas de idade são desconhecidos ao tolo, porquanto cada dia que passa não lhe faz achar no amor um bem mais caro, ou mais difícil a conquistar. Não tendo tido, nem melhorado, nem endurecido pelos reveses da vida, continuando a ver as mulheres com o mesmo olhar, exprime-lhes os seus amores com as mesmas lágrimas e os mesmos suspiros que lhes reserva para pintar os antigos tormentos. E como ele só exigiu delas aparências de paixão, vem facilmente a persuadir-se que é amado. Longe de fugir, persevera e - triunfa.

IX

O homem de espírito é o menos hábil para merecer a uma mulher.

Quando se arrisca a escrever uma carta, sente dificuldades incríveis. Desprezando o vasconço da galanteria, não sabe como se há de fazer entender. Quer ser reservado e parece frio; quer dizer o que espera e indica receio; confessa que nada tem para agradar, e é apanhado pela palavra. Comete o crime de não ser comum ou vulgar. As suas cartas saem do coração e não da cabeça; têm o estilo simples, claro e límpido, contendo apenas alguns detalhes tocantes. Mas é exatamente o que faz com que elas não sejam lidas, nem compreendidas. São cartas decentes, quando as pedem estúpidas.

O tolo é fortíssimo em correspondência amorosa, e tem consciência disso. Longe de recuar diante da remessa de uma carta, é muitas vezes por aí que ele começa. Tem uma coleção de cartas prontas para todos os graus de paixão. Alega nelas em linguagem brusca o ardor de uma chama; 
a cada palavra repete: meu anjo, eu vos adoro. As suas fórmulas são enfáticas e chatas; nada que indique uma qualquer personalidade. Não faz suspeitar excentricidade ou poesia; é quanto basta; é medíocre e ridículo, tanto melhor. Efetivamente o estranho que ler as suas missivas, nada tem a dizer; na mocidade o pai da menina escrevia assim: a própria menina não esperava outra cousa. Todos estão satisfeitos, até os amigos. Que querem mais?

\section{$\mathrm{X}$}

Enfim, o homem de espírito, em vista do que é, inspira às mulheres uma secreta repulsa. Elas se admiram com o ver tímido, acanham-se com o ver delicado, humilham-se com vê-lo distinto.

Por muito que ele faça para descer até elas, nunca consegue fazê-las perder o acanhamento; choca-as, incomoda-as e esse acanhamento, de que ele é causa, torna frias as conversações mais indiferentes, afasta a familiaridade e assusta a inclinação prestes a nascer.

Mas o tolo não atrapalha, nem ofusca as mulheres. Desde a primeira entrevista, ele as anima e fraterniza-se com elas. Eleva-se sem acanhamento nas conversas mais insulsas, palra e requebra-se como elas. Compreende-as e elas o compreendem. Longe de se sentirem deslocadas na sua companhia, elas a procuram, porque brilham nela. Podem diante dele absorver todos os assuntos e conversar sobre tudo, inocentemente, sem conseqüência. Na persuasão de que ele não pensa melhor, nem contrário a elas, auxiliam elas o triste, quando a idéia lhe falta, suprem-lhe a indigência. Como se fazem valer por ele, é justo que lhes paguem, e por isso consentem em ouvi-lo em tudo. Entregam-lhe assim os seus ouvidos, que é o caminho do seu coração, e um belo dia admiram-se de ter encontrado no amigo complacente um senhor imperioso!

XI

Compreende-se, por este curto esboço, como e quanto diferem os tolos e os homens de espírito nos seus meios de sedução. A conclusão final é que os tolos triunfam, e os homens de espírito falham, resultado importante e deplorável, nesta matéria sobretudo.

\section{XII}

Depois de ter indagado as causas da felicidade dos tolos, e da desgraça dos homens de espírito: perderemos tempo precioso em acusar as mulheres? Não hesitamos em deitar as culpas sobre os homens de espírito, como fez o profundo Champcenets.

Por que não estudam os tolos, diz-lhes este autor, para conseguir imitá-los? Há de custar-vos muito fazer um tal papel: mas há proveito sem desar? E depois, quando assim sois a isso obrigado, visto como não vos dão outro meio de solução, querer subtrair o belo sexo ao império dos tolos, descortinando-lhe a perversidade do seu gosto, é cousa em que ninguém deve pensar, é uma loucura; fora o mesmo que querer mudar a natureza, ou contrariar a fatalidade.

Porquanto, ficai sabendo, continua Champcenets, que as mulheres não são senhoras de si próprias; que nelas tudo é instinto ou temperamento, e que portanto elas não podem ser culpadas de suas preferências. Só respondemos pelo que praticamos com intenção e discernimento. Ora, qual delas pode dizer que predileção a impele, que paixão a obriga, que sentimento a faz ingrata, ou que 
vingança lhe dita as malignidades? Debalde procurareis nelas tão cruel prodígio; nenhuma é cúmplice do mal que causa; a este respeito, o seu estouvamento atesta-lhes a candura.

Por que vos obstinais em pedir-lhes o que a Providência não lhes deu? Elas se apresentam belas, apetitosas e cegas: não vos basta isto? querê-las com juízo, penetrantes e sensíveis, é não conhecê-las.

Procurai as mulheres nas mulheres, admirai-lhes a figura elegante e flexível, afagai-lhes os cabelos, beijai-lhes as mãos mimosas; mas tomais como um brinquedo o seu desdém, aceitai os seus ultrajes sem azedume, e às suas cóleras mostrai indiferença. Para conquistar esses entes frágeis e ligeiros, é preciso atordoá-los pelo rumor dos vossos louvores, pelo fato do vosso contrário, pela publicidade das vossas homenagens.

XIII

Sim, sim, é de mister ousar tudo para com as mulheres.

Fim 



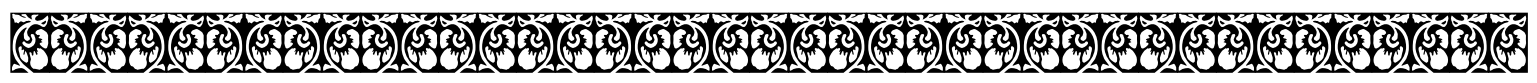 Conclusões

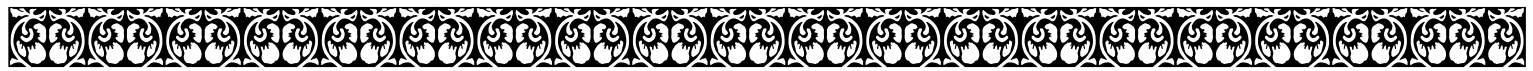

O objetivo primordial desse trabalho foi reunir em um único volume pela primeira vez todos os textos que Machado de Assis divulgou na Marmota de Paula Brito desde 1855 até 1861. A iniciativa de agrupar esse material tem como finalidade dar a conhecer, de forma prática e sistemática, o primeiro estágio da produção de Machado de Assis. Para tanto, buscou-se oferecer subsídios para o exame desses textos machadianos na forma de um ensaio sobre a própria Marmota, um estudo sobre a construção da figura de Francisco de Paula Brito e, finalmente, uma tentativa de estabelecimento do perfil estilístico e temático da produção de Machado de Assis para o jornal.

Pode-se verificar pelo estudo de seus aspectos editoriais que a Marmota de fato exercia um papel formador dentro da esfera cultural de sua época, embora ela não fosse um veículo da grande imprensa. Do mesmo modo, buscou-se inserir Paula Brito na dinâmica cultural do Segundo Reinado, procurando entender as relações entre o tipógrafo e seu periódico. Por fim, como cada obra literária deve ser entendida como resultado de um debate cultural maior estabelecido em seu tempo, com base nos estudos sobre o jornal e seu editor, ficaram mais claras as características das colaborações de Machado para a Marmota. Foi importante observar que embora o autor de Memórias Póstumas de Brás Cubas seja conhecido como o maior expoente da escola realista da literatura brasileira, seus primeiros textos saídos na imprensa são em grande parte poesias de cunho mais romântico, o que atesta o diálogo do autor com seu tempo e com a cultura do período. 



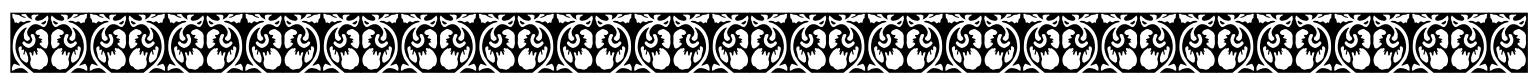 Referências Bibliográficas

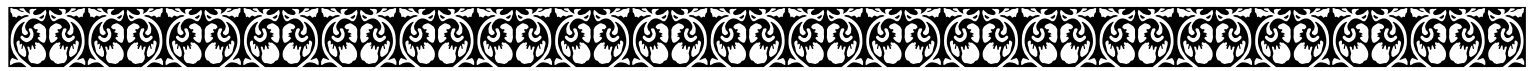

A Marmota na Corte. Rio de Janeiro, Tipografia de Paula Brito, 1849-1852.

A MARмота. Rio de Janeiro, Nova Tipografia de Paula Brito, 1857-1861.

Alencastro, Luiz Felipe (org.). História da Vida Privada no Brasil. Dir. Fernando A. Novais. São

Paulo, Companhia das Letras, 1997, vol. 2: Império: A Corte e a Modernidade Nacional.

Almeida, Pires de. A Escola Byroniana no Brasil. São Paulo, Conselho Estadual de Cultura/Comissão de Literatura, 1962.

Araújo, Emanuel. A Construção do Livro: Princípios da Técnica de Editoração. Rio de Janeiro/Brasília,

Nova Fronteira/INL, 2000.

Assis, Machado de. Crítica Literária. Rio de Janeiro, W. M. Jackson, 1957. . Crônicas. Rio de Janeiro, W. M. Jackson, 1957, vol. 1: (1859-1863). Crônicas. Rio de Janeiro, W. M. Jackson, 1957, vol. 2: (1864-1867). . Crônicas. Rio de Janeiro, W. M. Jackson, 1957, vol. 3: (1871-1878). . Crônicas. Rio de Janeiro, W. M. Jackson, 1957, vol. 4: (1878-1888). . Páginas Recolhidas. Rio de Janeiro, W. M. Jackson, 1937.

Azevedo Filho, Leodegário A. de. Iniciação em Crítica Textual. Rio de Janeiro/São Paulo, Presença/ Edusp, 1987.

Azevedo, M. A. Álvares de. Obras de Manuel Antônio Álvares de Azevedo, Precedidas de um Discurso Biográfico e Acompanhadas de Notas pelo Sr. Dr. Jacy Monteiro. 2. ed. Rio de Janeiro, Livraria de B. L. Garnier, 1862, tomo I.

Azevedo, Manuel Duarte Moreira de. "Biografa”. In: Brito, Francisco de Paula. Poesias de Francisco de Paula Brito. Rio de Janeiro, Tipografia Paula Brito, 1863.

Berger, Paulo. A Tipografia no Rio de Janeiro: Os Impressores Bibliográficos, 1808-1900. Rio de Janeiro, Imprensa Nacional/Cia. Industrial de Papel Pirahy, 1984.

Bethell, Leslie (org.). História da América Latina. São Paulo, Edusp, 2001, vol. III: Da Independência até 1870.

Blake, Augusto Victorino Alves Sacramento. Dicionário Bibliográfico Brasileiro. Rio de Janeiro, Tipografia Nacional, 1883.

Braga, Francisco Gonçalves. Tentativas Poéticas. Rio de Janeiro, Tip. Nicolau Lobo Vianna e Filhos, 1856.

Brito, Francisco de Paula. Poesias de Francisco de Paula Brito. Rio de Janeiro, Tipografia Paula Brito, 1863. 
Broca, Brito. Românticos, Pré-românticos, Ultra-românticos. São Paulo, Polis, 1979.

Bueno, Eduardo. Brasil: Uma História. São Paulo, Ática, 2005.

Candido, Antonio (org.). A Literatura no Brasil. Rio de Janeiro, Sul Americana, 1955, vol. 1, tomo 2. . Formação da Literatura Brasileira: Momentos Decisivos. 3. ed. São Paulo, Livraria Martins, 1969.

CARrer, Aline. Rio de Assis: Imagens Machadianas do Rio de Janeiro. Rio de Janeiro, Casa da Palavra, 1999.

Castello, José Aderaldo. A Literatura Brasileira: Origens e Unidade (1500-1960). São Paulo, Edusp, 1999. 2 vols.

CÉsAR, Guilhermino (org.). Historiadores e Críticos do Romantismo: 1 - A Contribuição Européia: Crítica e História Literária. São Paulo/Rio de Janeiro, Edusp/LTC, 1978.

Coaracy, Vivaldo. Memórias da Cidade do Rio de Janeiro. 3. ed. Belo Horizonte/São Paulo, Itatiaia/ Edusp, 1988.

Coutinho, Afrânio (org.). A Literatura no Brasil. Rio de Janeiro, Editorial Sul-Americana, 1955, vol. I, tomo 2.

Machado de Assis: Obra Completa. Rio de Janeiro, José Aguilar, 1959, 3 vols. Machado de Assis: Obra Completa. Rio de Janeiro, José Aguilar, 1962, 3 vols. Machado de Assis: Obra Completa. Rio de Janeiro, Nova Aguilar, 2006, 3 vols.

Cowper, William. Poems by William Cowper. Londres, J. Johnson, 1800, vol. 1.

Cruls, Gastão. Aparência do Rio de Janeiro (Notícia Histórica e Descritiva da Cidade). Rio de Janeiro, Livraria José Olímpio Editora, 1949, volume 2: Rio Ontem.

Derozier, Albert (ed.). Manuel José Quintana: Poesías Completas. Madri, Editorial Castalia, 1980.

Dias, Antônio Gonçalves. Cantos: Coleção de Poesias. 4. ed. Leipzig, F. A. Brockhaus, 1865. Últimos Cantos. Rio de Janeiro, Tipografia de F. de Paula Brito, 1851.

Duque, Gonzaga. “O Poeta Negro", Dom Casmurro, Rio de Janeiro, ano IV, n. 190, p. 4, 8 mar. 1941. Fausto, Boris. História do Brasil. 9. ed. São Paulo, Edusp/FDE, 2001.

Ferreir A, Orlando da Costa. Imagem e Letra: Introdução à Bibliologia Brasileira - A Imagem Gravada. 2. ed. São Paulo, Edusp, 1994.

FonseCA, Gondin da. Biografia do Jornalismo Carioca (1808-1908). Rio de Janeiro, Livraria Quaresma, 1941.

Machado de Assis e o Hipopótamo: Uma Revolução Biográfica. 5. ed. rev. e ampl. São Paulo, Fulgor, 1961.

FreIRE, Laudelino. Sonetos Brasileiros: século XVII-XX. 1. ed. Rio de Janeiro, M. Orosco \& C., 1904. . Sonetos Brasileiros: século XVII-XX. 2. ed. Rio de Janeiro, F. Briguiet \& C., 1913.

Fundação Bienal de São Paulo. Mostra do Redescobrimento: Arte Afro-brasileira. São Paulo, Associação Brasil 500 Anos Artes Visuais, 2000.

GARRETT, João Batista de Almeida. Flores sem Fruto. Lisboa, Imprensa Nacional, 1845. Folhas Caídas. Rio de Janeiro, Tipografia de N. Lobo Vianna Júnior, 1853.

Gondim, Eunice Ribeiro. Vida e Obra de Paula Brito: "Iniciador do Movimento Editorial no Rio de Janeiro" (1809-1961). Rio de Janeiro, Livraria Brasiliana Editora, 1965. 
Gordinho, Margarida Cintra (org.). Gráfica: Arte e Indústria no Brasil - 180 Anos de História. São Paulo, Bandeirante Gráfica e Editora, 1991.

Hallewell, Laurence. O Livro no Brasil: Sua História. 2. ed. rev. e ampl. São Paulo, Edusp, 2005.

Holanda, Sérgio Buarque de (org.). História Geral da Civilização Brasileira. 2. ed. São Paulo, Difusão Européia do Livro, 1969, tomo II: O Brasil Monárquico.

Horacio Flacco. Arte Poética. Trad. Francisco José Freire. Lisboa. Lisboa, Oficia Patriarcal de Francisco Luiz Ameno, 1758.

HouaIss, Antônio. Elementos de Bibliologia. São Paulo/Brasília, Hucitec/INL, 1983.

Hugo, Victor. Odes et Ballades. 4. ed. Paris, Charles Gosselin Librarie, 1829, tomo II.

Lamartine, Alphonse Marie de. Histoire de la Restauration. Paris, Pagnerre - V. Lecou - Furne et Co., 1853, tomo II.

Oeuvres Completes. Paris, Charles Gosselin - Furne - Pagnerre, 1847, tomo I.

LAufer, Roger. Introdução à Textologia: Verificação, Estabelecimento, Edição de Textos. Trad. Leda Tenório da Motta. São Paulo, Perspectiva, 1980.

Le Thermomètre Parlamentaire. L'Ami des Sciences: Journal du Dimanche, Paris, Imprimerie de J.-B. Gros et Donnaud, ano 3, n. 21, p. 336, 24 maio 1857.

Lemos, João de. Cancioneiros. Lisboa, Tipografia de J. G. de Sousa Neves, 1858.

Lima Sobrinho, Alexandre José Barbosa. Panorama do Conto Brasileiro: Os Precursores do Conto no Brasil. Rio de Janeiro, Civilização Brasileira, 1960, vol. 1.

Lopes, Hélio. A Divisão das Águas: Contribuição ao Estudo das Revistas Românticas - Minerva Brasiliense (1843-1845) e Guanabara (1849-1856). São Paulo, Conselho Estadual de Artes e Ciências Humanas, 1978.

Macedo, Joaquim Manuel de (org.). Ano Biográfico Brasileiro. Rio de Janeiro, Tipografia e Litografia do Imperial Instituto Artístico, 1876. 3 vols.

Machado, Ubiratan. A Vida Literária no Brasil durante o Romantismo. Rio de Janeiro, Eduerj, 2001.

Magalhães Júnior, Raimundo. Vida e Obra de Machado de Assis. Rio de Janeiro/Brasília, Civilização Brasileira/INL, 1981, vol. 1: Aprendizado.

Malerba, Jurandir. A Independência Brasileira: Novas Dimensões. São Paulo, Editora FGV, 2006.

Manonni, Laurent. A Grande Arte da Luz e da Sombra, Arqueologia do Cinema. São Paulo, Editora da Unesp, 2003.

Marmota Fluminense. Rio de Janeiro, Empresa Tipográfica Dous de Dezembro, 1852-1857.

Martins, Wilson. A Palavra Escrita: História do Livro, da Imprensa e da Biblioteca. 3. ed. São Paulo, Ática, 1998.

História da Inteligência Brasileira. São Paulo, Cultrix/Edusp, 1977, vol. II: 1794-1855.

Mascarenhas, Nelson Lage. Um Jornalista do Império (Firmino Rodrigues Silva). São Paulo, Companhia Editora Nacional, 1961.

Massa, Jean-Michel (org.). Dispersos de Machado de Assis. Rio de Janeiro, MEC/INL, 1965. . A Juventude de Machado de Assis (1839-1870): Ensaio e Biografia Intelectual. Rio de Janeiro, Civilização Brasileira/Conselho Nacional de Cultura, 1971.

Moisés, Massaud. A Literatura Portuguesa. 34. ed. São Paulo, Cultrix, 1999. 
Dicionário de Termos Literários. São Paulo, Cultrix, 1997.

Monteiro, José Ferreira (org.). Lísia Poética ou Coleção de Poesias Modernas de Autores Portugueses. Rio de Janeiro, Tip. Clássica de José Ferreira Monteiro, 1848, tomo III.

Morais Filho, Alexandre José de Melo. Artistas do Meu Tempo: Seguidos de um Estudo sobre Laurindo Rabelo. Rio de Janeiro, H. Garnier, 1905.

Cantares Brasileiros - Cancioneiro Fluminense no Quarto Centenário: Parte Musical. Rio de Janeiro, Jacinto Ribeiro dos Santos, 1900. Fatos e Memórias. Rio de Janeiro, H. Garnier, 1904.

Morales de Los Rios Filho, Adolfo. O Rio de Janeiro Imperial. Rio de Janeiro, Topbooks/ UniverCidade, 2000

Moreira de Azevedo, Manuel Duarte. "Biografia”. In: Brito, Francisco de Paula. Poesias de Francisco de Paula Brito. Rio de Janeiro, Tipografia Paula Brito, 1863.

O Rio de Janeiro: Sua História, Monumentos, Homens Notáveis. Rio de Janeiro, B. L. Garnier, 1877, vol. 2.

Morel, Marco \& Barros, Mariana Monteiro. Palavra, Imagem e Poder: O Surgimento da Imprensa no Brasil do Século XIX. Rio de Janeiro, DPA, 2003.

O EsPeLho. Rio de Janeiro, Tipografia de Paula Brito, n. 1-4, 1859.

Pechman, Robert Moses. Cidades Estreitamente Vigiadas: O Detetive e o Urbanista. Rio de Janeiro, Casa da Palavra, 2002.

Pereira, Lúcia Miguel. Machado de Assis: Estudo Crítico e Biográfico. 2. ed. São Paulo: Companhia Editora Nacional, 1939.

Pontes, Elói. Machado de Assis. São Paulo, Edições Cultura, 1943.

Pujol, Alfredo. Machado de Assis: Curso Literário em Sete Conferências na Sociedade de Cultura Artística de São Paulo. São Paulo, Tipografia Brasil, 1917.

Ramos, Péricles Eugênio da Silva. Do Barroco ao Modernismo: Estudos de Poesia Brasileira. 2. ed. rev. e aum. Rio de Janeiro, Livros Técnicos e Científicos, 1979.

Renault, Delso. O Rio Antigo nos Anúncios de Jornais (1808-1850). Rio de Janeiro, Livraria José Olímpio Editora, 1969.

Ricupero, Bernardo. O Romantismo e a Idéia de Nação no Brasil (1830-1970). São Paulo, Martins Fontes, 2004.

Rizzini, Carlos. O Livro, O Jornal e a Tipografia no Brasil. Rio de Janeiro, Kosmos, 1946.

Romero, Sílvio. História da Literatura brasileira: Contribuições e Estudos Gerais para o Exato Conhecimento da Literatura Brasileira. 7. ed. Rio de Janeiro/Brasília, José Olímpio/INL, 1980, vols. 3 e 5.

RónaI, Paulo. Não Perca o Seu Latim. Rio de Janeiro, Nova Fronteira, 2000.

Schwarcz, Lilia Moritz. As Barbas do Imperador: D. Pedro II, um Monarca nos Trópicos. 2. ed. São Paulo, Companhia das Letras, 2006.

Semeraro, Cláudia Marino \& Ayrosa, Christiane. História da Tipografia no Brasil. São Paulo, Museu de Arte de São Paulo Assis Chateaubriand, 1979.

SodrÉ, Nelson Werneck. História da Imprensa no Brasil. Rio de Janeiro, Civilização Brasileira, 1966. 
História da Literatura Brasileira. 7. ed. atual. São Paulo, Difel, 1982.

SousA, José Galante de (org.). Machado de Assis: Poesia e Prosa. São Paulo, Civilização Brasileira, 1957.

Bibliografia de Machado de Assis. Rio de Janeiro, MEC/INL, 1955.

Spaggiari, Bárbara \& Perugi, Maurizio. Fundamentos da Crítica Textual. Rio de Janeiro, Lucerna, 2004.

SpINA, Segismundo. Introdução à Ecdótica (Crítica Textual). São Paulo, Cultrix/Editora da Universidade de São Paulo, 1977.

Teixeira, Ivan. "Introdução". In: Assis, Machado de. Papéis Avulsos. São Paulo, Martins Fontes, 2005.

“O Uraguai: Diatribre contra o Regicídio e contra a Monarcomaquia”. In: Épicos. São Paulo, Edusp/Imprensa Oficial, 2008.

"Poética Cultural: Literatura \& História". Politeia: História e Sociedade, Vitória da Conquista, v. 6, n. 1, pp. 31-56, 2006.

Apresentação de Machado de Assis. 2. ed. São Paulo, Martins Fontes, 1988.

Tinhorão, José Ramos. História Social da Música Popular Brasileira. São Paulo, Editora 34, 1998.

Veríssimo, José. História da Literatura brasileira. 4. ed. Brasília, Editora Universidade de Brasília, 1963, vol. III.

Viana, Hélio. Contribuição à História da Imprensa Brasileira (1812-1869). Rio de Janeiro, Imprensa Nacional, 1945.

Zaluar, Augusto Emílio. Dores e Flores. Rio de Janeiro, Tipografia de F. de Paula Brito, 1851. 